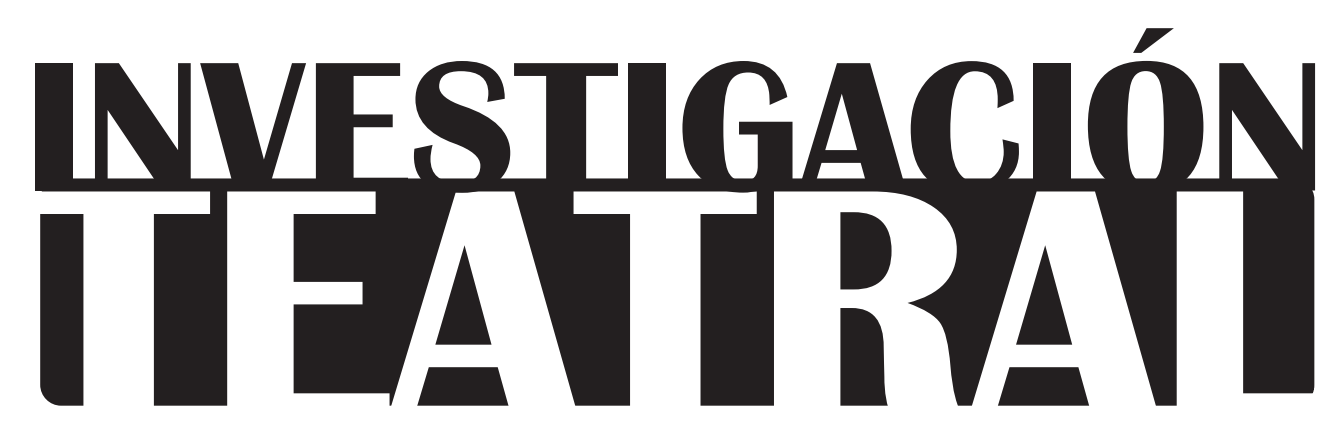

Revista de artes escénicas y performatividad
UNIVERSIDAD VERACRUZANA

Vol. 9, Núm. 13 abril-septiembre 2018

Segunda época

ISSN impreso: 1665-8728 ISSN electrónico: 2594-0953

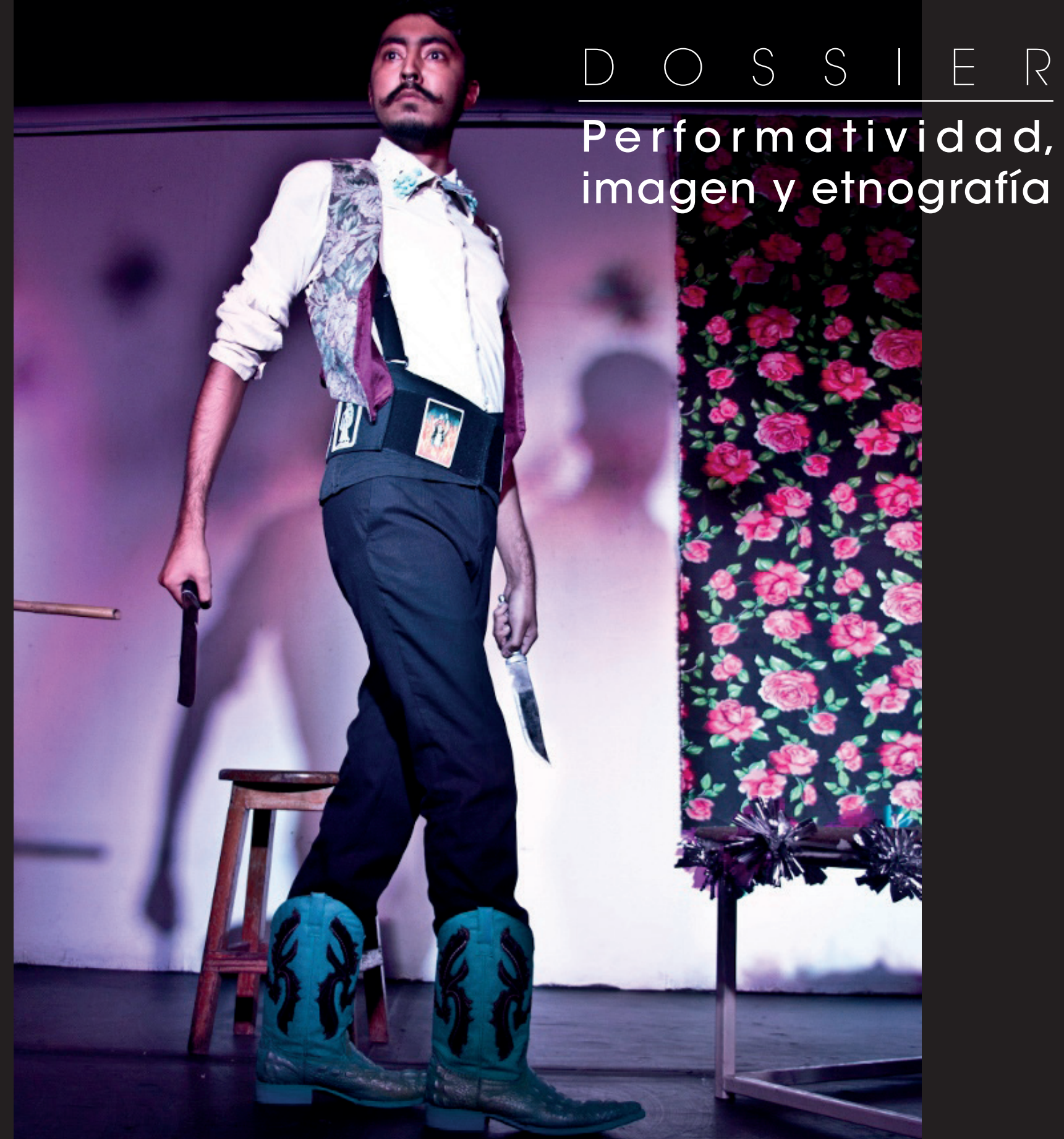




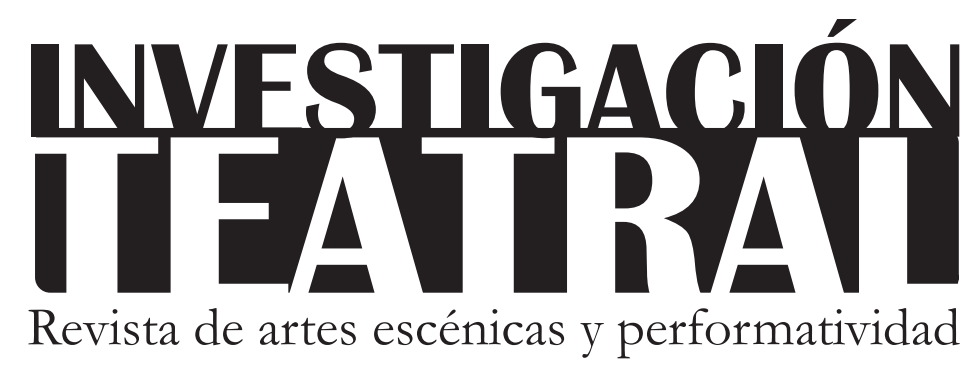

25 años a

(1993-2018) 
INVESTIGACIÓN

Revista de artes escénicas y performatividad

Director: Antonio Prieto Stambaugh (Facultad de

Teatro y CECDA, uv, México)

Editora: Gloria Luz Godínez Rivas (CECDA, UV, México)

Coordinación técnica y de vinculación: Verónica Herrera García

Asistentes de redacción y corrección: María Elena

Rivera Guevara e Indra Haritza Murillo Flores

\section{Consejo Editorial}

Elka Fediuk (CECDA, Uv, México)

Octavio Rivera (Facultad de Teatro, uv, México)

Domingo Adame (Facultad de Teatro, uv, México)

Arturo Díaz (Centro Nacional de Investigación

Teatral "Rodolfo Usigli"-INBA)

\section{Consejo Asesor}

José Ramón Alcántara (Universidad Iberoamericana, México)

André Carreira (Universidad do Estado de Santa

Catarina, Brasil)

Nel Diago (Universidad de Valencia, España)

Jorge Dubatti (Universidad de Buenos Aires,

Argentina)

Josette Féral (Universidad de Quebec, Canadá)

Jacqueline Bixler (Virginia Tech University, E.U.A.)

Donald Frischmann (Universidad Cristiana de Texas,

E.U.A.)

Óscar Armando García (Universidad Nacional

Autónoma de México, México)

Daniel Meyran (Universidad de Perpignan, Francia)

Rodolfo Obregón (Centro Nacional de Investigación

Teatral "Rodolfo Usigli"-INBA)

Alejandro Ortiz Bullé-Goyri (Universidad Autónoma

Metropolitana-A, México)

Diana Taylor (Universidad de Nueva York, Instituto

Hemisférico de Performance y Política, E.U.A.)

Diseño editorial y composición tipográfica: Héctor Hugo Merino Sánchez y Cynthia Maribel Palomino Alarcón

Corrección de estilo: Agustín Elizondo (CITRUINBA)

Imagen de la portada: Lechedevirgen Trimegisto en Pensamiento Puñal, 2013. Fotografía de Herani Enríquez Amaya.

\section{Dirigir correspondencia a:}

Revista Investigación Teatral, Centro de Estudios

Creación y Documentación de las Artes,

Universidad Veracruzana, Paseo de las Palmas 7,

Fraccionamiento Las Ánimas, Xalapa, Veracruz,

C.P. 91190, México. Tel. + 52 (228) 186-4314.

Correo electrónico:

investigacionteatraluv@gmail.com

\section{Versión electrónica:}

http://investigacionteatral.uv.mx

(c) Universidad Veracruzana

Investigación Teatral. Revista de artes escénicas y performatividad, Vol. 9, Núm. 13, abril 2018. Revista semestral del Cuerpo Académico Consolidado Teatro y el Centro de Estudios, Creación y Documentación de las Artes de la Universidad Veracruzana. Editor responsable: Dr. Antonio Prieto Stambaugh. Tel. (228) 8172134 y 18643 14. Reserva de derechos al uso exclusivo del título: No. 04-2013-032212535000-102, ISSN impreso 1665-8728 e ISSN electrónico 2594-0953, ambos otorgados por el Instituto Nacional de Derechos de Autor. Impresa por Códice Servicios Editoriales, Calle Violeta No. 7, Col. Salud, Xalapa, Veracruz, México. Este número se terminó de imprimir el 30 de abril de 2018 y el tiraje consta de 200 ejemplares. Distribución a cargo de la Facultad de Teatro, el CECDA y de la Dirección General Editorial de la Universidad Veracruzana.

Revista publicada con la colaboración del Centro Nacional de Investigación, Documentación e Información Teatral "Rodolfo Usigli". Este número fue impreso con recursos PFCE 2017. Agradecemos la gestión de la Dirección de la Unidad de Estudios de Posgrado de la uv.

El contenido de los textos publicados en esta revista queda bajo responsabilidad de sus autores. Se prohíbe la reproducción parcial o total de esta obra por cualquier medio, sistema y/o técnica electrónica o mecánica sin el consentimiento previo de la Universidad Veracruzana, y podrá hacerse siempre y cuando se cite la fuente incluyendo el título completo y textual del artículo, el nombre del autor, el nombre, la fecha y el número de la revista, así como el nombre de la institución editora. 


\section{Índice}

Presentación: 25 años de Investigación Teatral

Antonio Prieto Stambaugh . . . . . . . . . . . . . . . . . . . . . . 5

DOSSIER: PERFORMATIVIDAD, IMAGEN Y ETNOGRAFÍA

Introducción: Dossier "Performatividad, imagen y etnografía"

Rodrigo Parrini

Hortensia Moreno . . . . . . . . . . . . . . . . . . . . . . . . . . . . 8 8

Figuras del límite: Documentos, etnografía y teatro

Rodrigo Parrini . . . . . . . . . . . . . . . . . . . . . . . 14

Cuerpo estigmatizado y enunciación paratópica en la

performance de Lechedevirgen Trimegisto

Antoine Rodríguez. . . . . . . . . . . . . . . . . . . . . . . . . 35

Los talleres Drag King: Una metodología feminista de investigación encarnada Alba Pons Rabasa . . . . . . . . . . . . . . . . . . . . . . . . . . . . . . 55

El cuerpo del/la boxeador/a: danza y representación

Hortensia Moreno . . . . . . . . . . . . . . . . . . . . . . . . . . . . . . . .80

La labor afectiva del duelo: ofrendas, pérdidas y desapariciones en Guerrero

Anne W. Johnson. . . . . . . . . . . . . . . . . . . . . . . . . . . . 103

\section{TESTIMONIO}

"Alerta sísmica": teatro y heterotopías

Patricio Villarreal Ávila . . . . . . . . . . . . . . . . . . . . . . . . . . . . . . . 123

\section{SECCIÓN GENERAL}

El teatro como crítica institucional

Óscar Cornago . . . . . . . . . . . . . . . . . . . . . . . . . . . . . . . . . 132

Soberanía estallada: Memorias de Malvinas en Campo minado de Lola Arias

Verónica Perera . . . . . . . . . . . . . . . . . . . . . . . . . . . . . . . . 159

RESEÑA DE LIBRO

El teatro depurado y sin concesiones de Ludwik Margules, de María Teresa Paulín Rodolfo Obregón . . . . . . . . . . . . . . . . . . . . . . . . . . . . . 174

\section{RESEÑA DE PUESTA EN ESCENA}

La extinta variedad del mundo de Alberto Villarreal

Saúl Rivas Meléndez . . . . . . . . . . . . . . . . . . . . . . . . . . . . . . . . . . . 179 


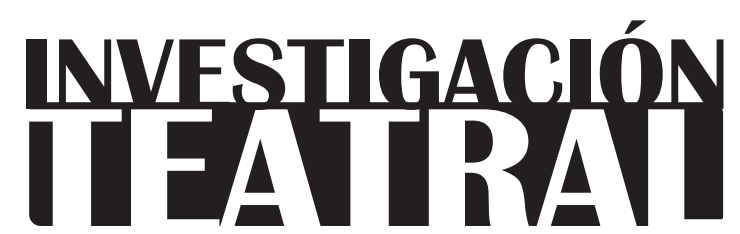

Revista de artes escénicas y performatividad

Vol. 9, Núm. 13

abril-septiembre 2018

Segunda época

ISSN impreso: 1665-8728

ISSN electrónico: 2594-0953

Universidad Veracruzana

\title{
Presentación: 25 años de Investigación Teatral
}

\author{
Antonio Prieto Stambaugh*
}

\footnotetext{
* Director de la revista Investigación Teatral, Universidad Veracruzana, México. e-mail: anprieto@uv.mx
} 


\section{Presentación:}

\section{5 años de Investigación Teatral}

$\mathrm{E}$ n 2018 conmemoramos 25 años de la creación de la revista Investigación Teatral, que inicialmente llevaba el subtítulo "Anuario de la Asociación Mexicana de Investigación Teatral" (АмIт). Esto representó un paso decisivo hacia la consolidación de los estudios teatrales en México, ya que con los congresos anuales de la AMIT y con la revista, los investigadores nacionales ahora teníamos foros para poner a discusión nuestros trabajos con colegas de otras disciplinas y diversos países. El primer número se editó en 1993, pero logró imprimirse hasta dos años después. Los artículos de ese número inaugural, presentado por Domingo Adame y Octavio Rivera, abordan desde el paradigma aristotélico de la representación (José Ramón Alcántara) hasta la necesidad de crear un aparato crítico para analizar el arte corporal del performance (Gabriel Weisz). Por su parte, Armando Partida escribe sobre la comedia soviética de los años 1920, Elka Fediuk sobre la formación actoral, Domingo Adame sobre la posmodernidad frente al teatro, y Fernando Carlos Vevia sobre Bertolt Brecht; trabajos todos ellos presentados en el primer Congreso de la AMIT hace también un cuarto de siglo. En 2002, Investigación Teatral logró regularidad semestral al ser acogida por la Facultad de Teatro de la Universidad Veracruzana (UV), en donde continuó su misión de divulgar trabajos inéditos de investigadores nacionales y extranjeros.

A partir de 2011, cuando se inaugura su segunda época, la revista comenzó a editarse en instalaciones del ahora Centro de Estudios, Creación y Documentación de las Artes (CECDA) de la UV, y en 2014 apareció en su versión electrónica, que hoy rebasa las 12 mil consultas. Además, Investigación Teatral pasó a convertirse en una revista arbitrada mediante rigurosos dictámenes de pares, miembros de nuestro Consejo Asesor, la AMIT, 
del Centro Nacional de Investigación Teatral "Rodolfo Usigli" (CITRU), y de universidades de todo el mundo. Finalmente, su nuevo subtítulo ("Revista de artes escénicas y performatividad") abre su campo temático a otras disciplinas de las artes escénicas, así como a fenómenos de performatividad cultural. El número que presentamos ahora es ejemplo de dicha apertura, con un dossier sobre performatividad, imagen y etnografía, coordinado por Rodrigo Parrini y Hortensia Moreno, colegas formados en la antropología y los estudios de género. La diversidad de los textos que nos llegan refleja a su vez las transformaciones que han venido presentando las artes escénicas durante el siglo xxI, cada vez más entretejidas con procedimientos interdisciplinarios, e interesadas en problemáticas de orden ético, social y político. Hoy por hoy, Investigación Teatral continúa siendo la única revista de su tipo a nivel nacional, y sus contenidos se enriquecen con colaboraciones de una nueva generación de investigadores egresados de posgrados como la Maestría en Artes Escénicas de la Universidad Veracruzana, que en 2018 cumple 10 años. Cerramos esta presentación agradeciendo al CITRU su interés por iniciar una nueva etapa de colaboración con Investigación Teatral, a fin de garantizar la continuidad de este proyecto. 


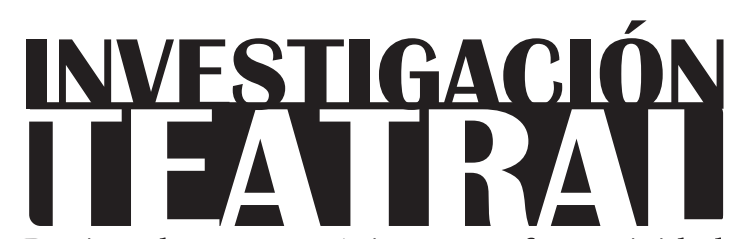

Revista de artes escénicas y performatividad

Vol. 9, Núm. 13

abril-septiembre 2018

Segunda época

ISSN impreso: 1665-8728

ISSN electrónico: 2594-0953

Universidad Veracruzana

\title{
Introducción
}

\section{Dossier "Performatividad, imagen y etnografía"}

\author{
Rodrigo Parrini* \\ Hortensia Moreno ${ }^{* * *}$
}

\footnotetext{
* Departamento de Educación y Comunicación, Universidad Autónoma Metropolitana, Unidad Xochimilco, México.

e-mail:rodparrini@gmail.com

** Centro de Investigaciones y Estudios de Género, Universidad Nacional Autónoma de México, México. e-mail: hortensiamoreno@gmail.com
} 


\section{Introducción}

\section{Dossier "Performatividad, imagen y etnografía"}

$\mathrm{E}$ dossier que presentamos en este número tuvo su origen en dos coloquios $^{1}$ dedi- $^{-}$ cados a las indagaciones multidisciplinarias en las prácticas de investigación en artes y ciencias sociales. En uno nos centramos en el teatro, la performatividad y el abandono; el otro, lo dedicamos a las heterotopías. Más allá de los temas específicos, nos interesaba interrogar las prácticas de investigación en campos diversos y los diálogos que se podían establecer entre ellas. Buscábamos propiciar un ejercicio colectivo de reflexión a partir de múltiples experiencias y atisbar los lenguajes en uso, las técnicas de investigación, las estrategias analíticas, los modos de interrogación, las imaginaciones involucradas y los puntos donde las rutas conceptuales o prácticas divergían.

El diálogo nos condujo a un desafío de límites entre campos formalmente separados, el cual generó tensiones, desfases y discordancias. Una de las más sobresalientes tiene que ver con la "división ocupacional entre el artista y el académico" (Jackson, 177-178): ¿cómo se inscriben las artes escénicas en el espacio formal, disciplinario y disciplinado de la vida académica? Porque nuestros sujetos/objetos de conocimiento, nuestras preguntas de investigación y nuestras "metodologías" parecían converger en estrategias de trabajo, lenguajes, formas de pensar, modos de aproximación e interrogación que, de manera colateral,

${ }^{1}$ El primero se realizó los días 30 de septiembre y 1 de octubre de 2015 en la Casa de Cultura de la Universidad Autónoma del Estado de México, en Ciudad de México. El segundo, los días 18 y 19 de octubre de 2016 en el Centro Cultural de España en la misma ciudad. Ambos coloquios fueron organizados por la Universidad Autónoma Metropolitana, Unidad Xochimilco, en colaboración con la Universidad Autónoma del Estado de México y la Universidad Autónoma Metropolitana, Unidad Cuajimalpa. 
nos conectan con los estudios del performance y, por consiguiente, nos enfrentan a una cuestión que rebasa con mucho las prácticas de investigación.

Por eso propusimos este conjunto de reflexiones a una revista dedicada a las artes escénicas y la performatividad que, además, dedica buena parte de su espacio al mundo del performance. El performance pensado como acción/actuación/actualización, puesta en acto y escenificación de normas y órdenes, subversión y atravesamiento de límites; reproducción y diferencia que alude, al mismo tiempo, a la irrepetibilidad del acontecimiento y a su pertenencia a una estructura que le otorga significación dentro del marco contextual del aquí-y-ahora, es decir, al reconocimiento de que nuestras vidas están estructuradas de acuerdo con modos de conducta repetidos y socialmente sancionados. Todo lo cual sugiere una lucha por el control de una economía simbólica.

Los trabajos reunidos aquí tienen en común ese punto de partida. No se puede pensar el performance como un género artístico o como el dominio estricto de una disciplina estética en sí misma, sino como una pluralidad de expresiones. De la misma forma, los referentes de nuestras contribuciones son diversos y heterogéneos: desde prácticas corporales cotidianas como los usos indumentarios hasta la extrema codificación del cuerpo en la danza o el deporte, pasando por experiencias autodenominadas como teatrales, escenificaciones paratópicas y rituales colectivos del duelo. Lo que permite la interlocución entre experiencias y ejercicios tan dispares es su anclaje en lo que Allan Kaprow ha denominado el "arte como vida", es decir, el arte que mezcla los géneros o los evita: "el principal diálogo de los hacedores del arte como vida no se lleva a cabo con el arte, sino con todo lo demás".

Si bien la confusión de categorías ha ampliado la gama de lo que cuenta como práctica artística, lo que nos interesa de esta experiencia en tanto teatro, imagen y etnografía es una conversación interdisciplinaria que vulnera los límites entre modalidades y borra las fronteras entre los medios, los géneros o las tradiciones culturales. Porque la discusión nos conduce a la toma de conciencia de la "índole contingente, resbalosa y decididamente contextual de la formación de conocimiento" (Jackson, 10). Refrenda la idea de Feyerabend de que no existe una sola fuente del saber, ni una única manera legítima de transmitirlo. El desafío principal de nuestras prácticas epistemológicas consiste en mantenerse como marca de frontera entre campos del saber y desestabilizar la idea de que existe una forma única - estandarizada, universal, normativa - de producir conocimiento.

En alguna medida, las perspectivas multidisciplinarias o transdisciplinarias contienen un elemento mítico que anuncia una mutua comprensión o la integración de los lenguajes y los modos de intervenir sobre ciertas realidades o fenómenos. Nuestra pos-

${ }^{2}$ Citado en Schechner, 2002 (tomado de “The Real Experiment”, 36-38). La traducción es nuestra. 
tura fue sospechar de ese horizonte, pero creer en el mito. Los coloquios fueron, en ese sentido, ejercicios rituales para mitologías en ciernes.

Nuestro interés común surge de una experiencia singular, pero compartida, de extrañamiento. Por un lado, una de las colaboradoras (Hortensia Moreno) investigó durante largo tiempo prácticas corporales de boxeadoras y se adentró en un mundo repleto de imágenes, rituales, límites y creencias. Por otro, Rodrigo Parrini se encontró con una compañía de teatro en una ciudad de la frontera sur de México - lugar poco acostumbrado al arte de la capital- y comenzó una interrogación sobre las relaciones entre sus propias prácticas etnográficas y las prácticas teatrales que realizaba ese grupo de artistas. ¿Se puede interrogar al boxeo desde la semiótica y el feminismo?, ¿es factible ver en ese deporte un mundo particular y en las mujeres que lo practican sujetos singulares?; ¿podríamos pensar una etnografía que se realiza a través del teatro?, ¿o un teatro que rebasa la escena y se aproxima a los mundos de vida y a las teatralidades que ahí se producen? El extrañamiento del que hablamos surge de ese encuentro fortuito, pero también intencionado, con otros lenguajes y otras estéticas. Extrañarse es el principio de la interrogación, se lea esa actitud como inicio de algo o como un imperativo intelectual.

En el teatro o en el boxeo se escuchan muchas voces. Son mundos llenos de sonidos, incluso en los intervalos de silencio que cobijan. Esas voces, que se desplazan con quien las ha escuchado ya no como un mundo sonoro sino como una interioridad bullente, abren diálogos, suscitan asociaciones, crean argumentos. Los artículos que hemos reunido en este número forman parte de ese espacio colmado de referencias e imágenes. En algún sentido, es tanto un mundo de voces como una interioridad parlante. Esa convergencia razonada de la que hablamos antes es también una subjetividad comprometida. Si bien podríamos abordar el arte como una institución o la etnografía como una metodología, preferimos ubicarnos en una posición de perturbación serena en la que los desencuentros produzcan sentidos que no hemos avizorado. Si bien ninguno de los textos que hemos reunido propone rupturas definitivas, todos, a su manera, registran desacomodos importantes: del cuerpo con el sentido, del arte con la conciencia, del deseo con el lenguaje, de la muerte con sus rituales.

$\mathrm{Al}$ parecer, las formas de vida en el mundo actual experimentan una crisis profunda en lo que Paolo Virno llama sus sustratos de piedra. Crisis que Peter Sloterdijk denomina simplemente "modernidad", pero que nosotros evitamos nombrar ante la urgencia de una descripción pormenorizada. ¿Son los elaborados rituales mortuorios que realizan los habitantes de una localidad de Guerrero suficientes para resolver colectivamente la desaparición sistemática de personas que ocurre en ese estado mexicano?, ¿cómo ritualizar la muerte de aquellas personas cuyo destino se desconoce y cuyos cuerpos no han sido encontrados? El texto de Anne Johnson se adentra en esas preguntas, mediante su propio involucramiento 
en las prácticas rituales y una inquietud política afligida por la violencia creciente. El abigarramiento de las imágenes y objetos que se utilizan para recordar a un muerto o para conmemorarlo se contrapone al vacío de la desaparición; la presencia atiborrada, a la ausencia angustiosa. En ese deslinde entre la fuerza socializante de los rituales y la dispersión de la violencia, la pregunta antropológica por el dolor se aproxima a las interrogaciones estéticas: “ ¿cómo es que, en nuestro contacto con las obras, con las imágenes, se encuentra ya proyectada una relación con el dolor?", se pregunta Georges Didi-Huberman (48).

De la misma forma, en otros escenarios, la pregunta autoetnográfica sobre la producción del género como efecto de los usos del vestir se responde solamente en la experiencia del propio cuerpo. Acá lo que está en juego ya no es solamente el espectáculo de la presentación de sí ante un público en un proscenio, sino sobre todo la preparación del espectáculo: el trabajo de vestuario, maquillaje, accesorios, peinado; y de manera concomitante, el ensayo de gestos, poses, manierismos, tonos de voz, actitudes, van produciendo un cuerpo que se reconoce a un tiempo como mismidad y alteridad. El trabajo de Alba Pons explora formas de acceso al saber que podríamos caracterizar como un aprendizaje "en el cuerpo", como formas de re-conocimiento del saber que reside en el cuerpo y no rebasa la esfera de lo común y lo ordinario. Y a la vez, recupera la capacidad reflexiva de las personas en situaciones donde se re-escenifican hábitos, costumbres, rituales, modales o códigos de interacción que determinan prácticas sociales vividas como "naturales", "normales" o "normativas".

De una forma distinta, y con otros materiales, Antoine Rodríguez interroga las prácticas de un artista y performer queer mexicano que elabora escenas de violencia y de deseo utilizando su cuerpo como escenario, objeto, cuadro o desecho. Las performances de Lechedevirgen Trimegisto son rituales privados que el artista exhibe como ejecuciones públicas que no alcanzan a consumarse. Por eso, en sus prácticas está en juego la capacidad de interpelación política de algunas formas de arte, pero también un modo de elaboración del lenguaje y los afectos transidos por la violencia. Tenemos la impresión que sus trabajos no son pasajes al acto que desplieguen la violencia, pero tampoco simbolizaciones que la desplacen; son más bien un juego en el filo de lo que surge como deseo y lo que perturba como violencia. ¿No es el estigma una marca visible pero también oculta? A Lechedevirgen lo estigmatizan su deseo, su fenotipo, sus prácticas artísticas, dice Rodríguez, y a la vez él transforma su cuerpo en un arma, en un manifiesto de intensidades eróticas y políticas que no propone un discurso cerrado o coherente, sino que saca chispas, incluso con su piel y sus órganos, y suscita nuevas opacidades y brillos inéditos que muestran la intimidad, pero también la ocultan.

El testimonio que escribieron Patricio Villarreal y los integrantes de Teatro Ojo, a partir de un laboratorio que realizaron en unos de los coloquios que mencionamos antes, explora un síntoma que se manifestó de forma inesperada en la vida social de México. Didi-Huberman lee 
un síntoma como "la fisura en los signos, la pizca de sinsentido y de no saber de dónde un conocimiento puede extraer su momento decisivo" (24). Una de sus piezas -México mi amor. Nunca mires atrás - abordaba el sismo que acaeció en la capital del país en septiembre de 1985 y que dejó profundas huellas y heridas en sus habitantes. Desde una azotea del Centro Cultural de España en México, ubicado a unos metros del Templo Mayor y la Catedral Metropolitana, el colectivo teatral fue trazando un mapa visual de los distintos puntos donde habían intervenido con sus piezas. Por las ventanas podíamos ver la ciudad y sus edificios emblemáticos. Pero, por otra parte, el edificio de ese centro cultural estaba construido sobre un calmecac, antigua escuela para nobles mexicas, cuyos rastros se habían convertido en un museo de sitio subterráneo. Desde arriba se podía observar el pasado cercano y el futuro de la ciudad; abajo un pasado remoto. Teatro Ojo jugó con las temporalidades heterogéneas que se traslapaban en ese edificio.

Unos meses después del laboratorio, el mismo día que se conmemoraban los 32 años del sismo de 1985, otro fuerte terremoto sacudió la ciudad y sus alrededores, mató a varios cientos de personas y dañó miles de edificios. Una fisura social atravesó la urbe; un sinsentido organizado por una coincidencia funesta desordenó las explicaciones y las narrativas sobre los terremotos; emergió un no-saber del que los habitantes de la ciudad podían extraer un momento decisivo de destrucción y pregunta. En torno a ese síntoma, en el que se repite todo como si nunca hubiese sucedido o no dejara de ocurrir, Villarreal y Teatro Ojo elaboran un texto que intenta registrar otros temblores, como los proyectos sismográficos que Aby Warburg imaginó entre las guerras mundiales desde algún sanatorio de Europa o el temblor que afectaba a Derrida en sus últimos años de vida. Sacudidas de la historia, del cuerpo o de los subsuelos.

\section{Bibliografía}

Didi-Huberman, Georges. 2012. Arde la imagen. México: Ediciones Ve. Jackson, Shannon. 2004. Professing Performance. Theatre and the Academy from Philology to Performativity. Cambridge: Cambridge University Press.

Schechner, Richard. 2002. Performance Studies: An Introduction. Londres y Nueva York: Routledge.

Sloterdijk, Peter. 2003. Experimentos con uno mismo. Una conversación con Carlos Oliveira. Valencia: Pre-Textos, traducción de Germán Cano.

Virno, Paolo. 2011. Ambivalencia de la multitud: entre la innovación y la negatividad. Buenos Aires: Tinta Limón, traducción de Emilio Sadier y Diego Picotto. 


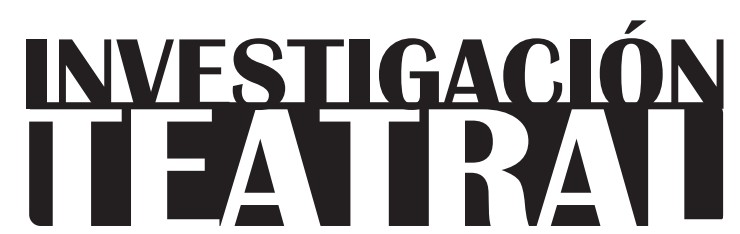

Revista de artes escénicas y performatividad

Vol. 9, Núm. 13

abril-septiembre 2018

Segunda época

ISSN impreso: 1665-8728

ISSN electrónico: 2594-0953

Universidad Veracruzana

\title{
Figuras del límite: Documentos, etnografía y teatro
}

\author{
Rodrigo Parrini*
}

\footnotetext{
* Departamento de Educación y Comunicación, Universidad Autónoma Metropolitana, Unidad Xochimilco, México.

e-mail:rodparrini@gmail.com
}

Recibido: 01 de septiembre de 2017

Aceptado: 29 de enero de 2018 
INVESTIGACIÓNTEATRAL

Revista de artes escénicas y performatividad

Vol. 9, Núm. 13

abril-septiembre 2018
Figuras del límite: Documentos,

etnografía y teatro

Rodrigo Parrini

\title{
Figuras del límite: Documentos, etnografía y teatro
}

\section{Resumen}

En este artículo reflexiono sobre las relaciones entre el teatro y la etnografía, a partir de un trabajo realizado con la agrupación Teatro Línea de Sombra entre migrantes centroamericanos, en la frontera sur de México. Mi interés no es describir etnográficamente lo acontecido, sino pensar el encuentro y entrecruzamiento de dos formas de documentación - la teatral y la etnográfica- y sus relaciones con un proceso poético de lectura y reconfiguración de una realidad que abordan en conjunto. Utilizo la noción de límite para trazar un eje de tensión entre las aproximaciones y miradas de ambas disciplinas.

Palabras clave: antropología, arte, documento, migración, frontera, México.

\section{Figures at the Limit: Documents, Ethnography and Theatre}

\begin{abstract}
In this article, I reflect on the relationship between theater and ethnography, with focus on a creative collaboration with the group Teatro Línea de Sombra (Shadow Line Theatre) and Central American migrants on the southern border of Mexico. The article aims to address the encounter and intertwining of two different forms of documentation - theatrical and ethnographic - and how they simultaneously relate with a poetic process that 'reads' a specific social reality. I use the concept of limit to create a tension between the approaches and perspectives of these two disciplines.
\end{abstract}

Keywords: anthropology, art, document, migration, border, Mexico. 


\section{Figuras del límite: Documentos, etnografía y teatro}

Toda literatura es un asalto al límite Franz Kafka

$\mathrm{E}$ n este artículo exploro algunos vínculos entre teatro y etnografía a partir de una experiencia con la agrupación Teatro Línea de Sombra (TLS). ${ }^{1}$ Este grupo montó Amarillo - una pieza dedicada a la migración que cruza la frontera norte de México para ingresar a los Estados Unidos de forma ilegal- en noviembre de 2013 en la ciudad de Tenosique, Tabasco. Dicha localidad se ha transformado en uno de los puntos más importantes de entrada de migrantes centroamericanos indocumentados a México y ahí se localiza el Hogar-Refugio para Migrantes "La 72", fundado por sacerdotes franciscanos en junio de 2011. ${ }^{2}$ Además de las dos funciones que dio de esa pieza, TLS realizó una serie de

1 Teatro Línea de Sombra es un proyecto cultural creado en 1993, conformado por creadores escénicos, pedagogos, investigadores y actores. En su página web, la agrupación define su trabajo como una "exploración en el quehacer contemporáneo del teatro y en los mecanismos de acercamiento e intercambio con otras y diversas experiencias de la creación escénica en el ámbito nacional e internacional", que privilegia "las zonas fronterizas de lo escénico" con otras disciplinas y la investigación "de los procesos de la escena y la creación, a partir de nuevas dramaturgias, procesos transdisciplinarios y la incorporación de relaciones nuevas con otros campos del conocimiento" (Teatro Línea de Sombra parr. 2).

${ }^{2}$ Fundado el 25 de abril de 2011 en la ciudad de Tenosique, este hogar es un proyecto de la Provincia Franciscana San Felipe de Jesús en el sureste de México. Su nombre recuerda la matanza de 72 migrantes - la 
actividades paralelas relacionadas con la migración que buscaban generar una aproximación sensible y crítica a este fenómeno por parte de los habitantes de la localidad.

En este texto no me interesa describir lo acontecido, sino en pensar el encuentro y entrecruzamiento de dos formas de documentación, la teatral y la etnográfica, y sus relaciones con un proceso poético de lectura y reconfiguración de una realidad que abordan en conjunto, pero también en paralelo. A partir de la colaboración con TLS, he seguido trabajando en una exploración etnográfica de los procesos de creación artística que alumbre los métodos antropológicos de investigación social. ${ }^{3}$

En las siguientes páginas me detendré a reflexionar, de modo ensayístico, sobre las estrategias de producción de la realidad que comprometen al teatro y a la etnografía, las formas de imaginación que ellas elaboran y las posibilidades que inaugura una lectura teatral de la migración, frente a otra etnográfica. Utilizo la noción de límite para trazar justamente un eje de tensión entre las aproximaciones y miradas del teatro y aquellas de la etnografía. Mi reflexión se centrará en identificar qué puede imaginar el teatro, en comparación con la antropología, frente a los mismos materiales. Despliego, por tanto, un ejercicio de imaginación etnográfica a partir de una impotencia asociativa que el teatro diluiría.

En un escrito sobre el neorrealismo italiano y el cine de Roberto Rossellini, Georges Didi-Huberman distingue los cuerpos documentados de los cuerpos líricos (ver Pueblos expuestos). Sostiene que podemos observar las escenas del cine de ese director italiano "desde la perspectiva rigurosa de los movimientos del trabajo" (169), que documentan con exactitud cómo sucede algo en la vida social (una redada policial o la pesca en un lago), y también desde "la óptica poética de los movimientos del pathos" (ibíd.), que introducen el amor y la muerte en esas escenas. Se trata de una poderosa distinción conceptual que, sin embargo, el autor no desarrolla cabalmente. En este artículo será retomada, pero desplazándola hacia las formas de generar interpretaciones e imágenes. Dado que trabajo con materiales que provienen tanto de la etnografía como del teatro, trazaré una distinción entre una aproximación documental, propia de la primera, y otra lírica, característica del segundo. Como se comprenderá, estos argumentos no son taxativos; se trata de reflexiones provisionales que permitirán desplegar una discusión.

Las figuraciones, escribe Donna Haraway, "son imágenes performativas que pueden ser habitadas. Las figuraciones, verbales o visuales, pueden ser mapas condensados de mundos

mayor parte centroamericanos - en la ciudad de San Fernando, Tamaulipas, en agosto de 2010, efectuada por células del crimen organizado en complicidad con la policía local. Este hogar es el primero que encuentran los migrantes que entran a México por la frontera entre Tabasco y Guatemala; les ofrece alojamiento, comida, atención jurídica, orientación y primeros auxilios.

${ }^{3}$ Ver Parrini, “Cuerpos figurantes..." y “Canto de palomas...”. Este último título se encuentra en prensa. 
discutibles" (28). Si las figuras que esbozaremos fueran mapas de mundos discutibles, condensarían de alguna manera el potencial disruptivo de tales mundos; es decir, los discutirían antes de que otras formas discursivas lo hicieran. La antropología se ha ocupado de figuras liminares o momentos de tránsito en que los sujetos pasaban ciertos umbrales para reingresar al orden social con un nuevo estatus (Turner 1991). Se trataba de figuras del límite, pasajeras y descriptibles. Las nuevas figuras del límite no surgen, a mi entender, de esas transiciones pautadas, sino de un desajuste generalizado de los espacios y las habitabilidades. Los umbrales rituales han sido reemplazados por umbrales biopolíticos donde las multitudes se agolpan sin poder salir. No hay tránsito y el umbral parece extenderse infinitamente. Un antropólogo sostiene que para los migrantes centroamericanos todo México es una frontera: una frontera vertical extensa (Fábregas Puig, "El concepto de frontera"). ¿Cómo comprender una frontera que se extiende como un territorio y que ya no es el límite sino la extensión misma? ¿Qué umbrales serían aquellos a los que se entra pero de los que aparentemente no se sale?

Los mapas de mundos discutibles que aquí están en juego, delinean el proceso migratorio en la frontera sur y - como dije antes - se produjeron en torno a ellos materiales líricos y documentales. Las figuras del límite que me interesa analizar son condensaciones singulares en esos mapas, localizadas en esos umbrales extensos y esas transiciones infinitas. Son, ante todo, nodos de una expulsión y no de una habitabilidad. ${ }^{4}$ La etnograf ía y el teatro dan cuenta de ellos de modos distintos. ${ }^{5}$

\section{Correspondencias y fronteras}

Trazar una línea tajante entre antropología y etnografía reedita viejas discusiones disciplinares y también sus horizontes futuros. Un modo clásico de distinguirlas ha sido atribuir a la etnografía el trabajo de campo y la descripción, y a la antropología la escritura y el análisis (Ingold 87). Si bien no es éste el lugar para reconstruir dicho punto de vista, parece que

${ }^{4}$ Saskia Sassen considera que la expulsión es una forma inédita, múltiple y compleja, mediante la cual poblaciones enteras son apartadas del desarrollo social y económico y dejadas a su suerte, que no puede ser explicada sólo por la desigualdad creciente que afecta a muchas sociedades contemporáneas. Sassen identifica algunas "lógicas de expulsión" que organizan un proceso de transformación social singular, en el que "la línea divisoria entre los que tienen acceso a los beneficios y los que no lo tienen se ha agudizado" y se ha hecho irreversible (11-12).

${ }^{5}$ La distinción que planteo entre teatro y etnografía puede resultar tajante y reductora. Entiendo que ambos campos son plurales y que no existe un teatro como tampoco una etnografía. Mantendré la distinción con fines analíticos y retóricos, sin perder de vista la diversidad que atraviesa a ambas disciplinas. 
diferenciar a una de otra es relevante para afincar los límites de la disciplina en su totalidad (Descola 66). A su vez, trazar una frontera clara entre el trabajo de campo y la escritura resulta igual de problemático. Al parecer, la antropología requiere una topología de sus actividades que no sólo las distinga, sino que también genere una cierta parsimonia en la que imaginamos que primero observamos y luego escribimos, o que el trabajo de campo (cualquiera que éste sea) sucede en un lugar distinto al de la escritura. También están en juego las temporalidades disciplinarias que permiten la organización de una investigación. Ingold argumenta que el trabajo de campo es una distinción imaginaria, una línea que se dibuja sobre la labor antropológica para diferenciar momentos y espacios.

Si la antropología no es etnografía, como sostiene el autor citado, esto se debe a que la primera es un diálogo incesante del antropólogo consigo mismo, con los otros y con el mundo que sucede mediante una correspondencia entre el antropólogo y sus interlocutores. ${ }^{6}$ No empieza al regresar del 'campo', porque éste no es más que un término que le permite al etnógrafo reunir e imaginar lo que ha dejado atrás cuando se encuentra abocado a describirlo en la escritura (88).

Laura Nader, por su parte, sostiene que la etnografía no sólo es una descripción, sino también una "teoría de la descripción" (211). Podríamos invertir el argumento de Ingold y pensar que la antropología es aquello que el etnógrafo imagina que hará cuando regrese de su trabajo de campo; entonces, la diferencia entre una y otra radicaría en sus desplazamientos y énfasis, antes que en las formas de conocimiento y los modos de escritura.

No obstante, pensar los límites me parece en este caso más un ejercicio antropológico que etnográfico, y corresponde al momento de inscribir un trabajo científico entre otras prácticas, por ejemplo, las artísticas. Si bien aquí me centro en la experiencia etnográfica que ocurrió a partir del encuentro con el lenguaje y el trabajo teatral y artístico, la lectura que propongo interroga las fronteras disciplinarias que comprometen la labor antropológica. Siguiendo a Ingold, la escritura de este texto traza un instante singular (que he llamado etnográfico) en el que sucedieron ciertos acontecimientos que tuvieron alguna forma de documentación. Si bien podría pensar que el artículo es una correspondencia, en el sentido polisémico del término, con otros interlocutores, también es una advertencia sobre los límites de dicho intercambio, dado que el lenguaje común que supone ese diálogo se ve perturbado por otros lenguajes que no son completamente traducibles.

La frontera entre teatro y etnografía sería el hiato en el que las correspondencias no llegan necesariamente a su destino o en que aquello que contienen, si las leyéramos, no resultaría cabalmente comprensible.

6 Así como el conocimiento etnográfico implica un intercambio intersubjetivo no replicable (Descola 69). 
INVESTIGACIÓNTEATRAL

Revista de artes escénicas y performatividad

Vol. 9, Núm. 13

abril-septiembre 2018
Figuras del límite: Documentos,

etnografía y teatro

Rodrigo Parrini

\section{Primer límite: la peste y los colgados}

A inicios de 2015 asistí, junto con algunos integrantes de Teatro Línea de Sombra, a una sesión de tarot; le pedí a una amiga tarotista que realizara una consulta colectiva grabada, a lo que ella accedió de manera excepcional. La pregunta era cómo encontrar un lenguaje para el proyecto que estábamos desarrollando y que se llamaba Carnaval de abandonados. ${ }^{7}$ Buscábamos encontrar, en el carnaval que cada año se realiza en Tenosique, un lenguaje y un espacio para discutir el abandono de los migrantes que transitaban por la localidad, política y performativamente. La noción de abandono se volvió central en mi trabajo etnográfico cuando desplacé mis preocupaciones de la sexualidad a la migración; fue un concepto que me permitió vincular las condiciones estructurales que organizaban la vida de las personas no heterosexuales, de las trabajadoras sexuales y de las personas que viven con VIH en la ciudad con las experiencias de los migrantes centroamericanos.

Propuse al tarot como un camino que nos acercara ese mundo a través de imágenes y metáforas. Alejandro Jodorowsky define al tarot como "un organismo de imágenes y formas [...], uno de los primeros lenguajes ópticos de la humanidad [que] responde a unas reglas de óptica proyectiva" (Psicomagia 125).

La carta que abrió la lectura fue El colgado, el doceavo arcano mayor del Tarot de Marsella. El colgado representaba el arcano mayor de los abandonados, que era el colectivo que orientaba la sesión. Jodorowsky propone pensar esta figura como "una inversión de la mirada y de sus perspectivas" (La vía del Tarot 220). Los abandonados, escribe Giorgio Agamben, están expuestos en un umbral donde vida y derecho, exterior e interior, se confunden (ver Homo sacer I). Están bajo un bando que los conmina y también los vulnera; han quedado a merced del poder, pero también entregados a su propia voluntad. En ellos, viejas figuras del derecho convergen con formas inéditas de desamparo o violencia.

En la lectura de tarot, los abandonados aparecían fragmentados por un orden social alienante, separados de sus propias emociones:

Y ahí están señalados por los militares, por el gobierno, están señalados si entran o no a un camión, si los bajan o suben. Es una batalla constante, la guerra, la revolución. Ellos viven todos los días con una revolución para poder obtener algo. No se les da tan fácil la vida. ${ }^{8}$

\footnotetext{
7 El proyecto culminó en febrero de 2016, cuando varias decenas de migrantes, muchos alojados en "La 72", y otros residentes en Tenosique, participaron en la comparsa migrante que ha desfilado en el carnaval. En otro texto analizo con detalle este acontecimiento (Parrini, "Cuerpos figurantes...").

${ }^{8}$ Lectura de tarot, 14 de marzo de 2015.
} 
INVESTIGACIÓNTEATRAL

Revista de artes escénicas y performatividad

Vol. 9, Núm. 13

abril-septiembre 2018
Figuras del límite: Documentos, etnografía y teatro

Rodrigo Parrini

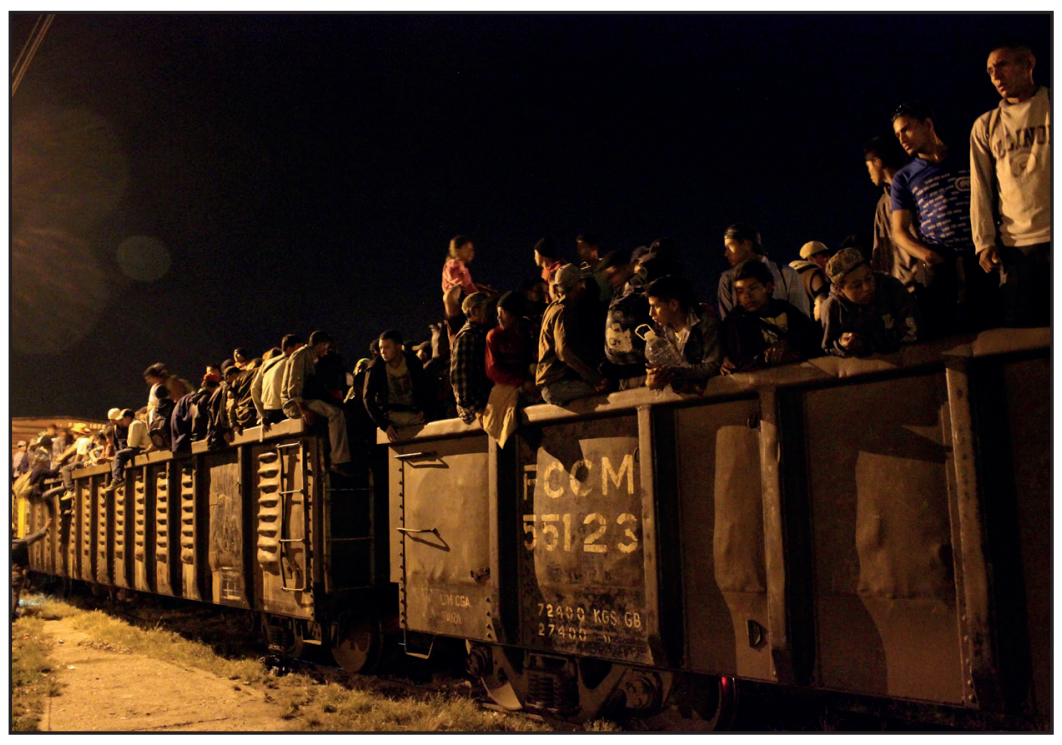

Vía Crucis Migrante. Tenosique, México, 2014. Fotografía de Marina España

El colgado es, literalmente, un migrante que viaja en tren, asido de alguna de sus partes para no caer. Pero también es el cadáver anónimo que queda expuesto en algún lugar público. Leeré el abandono a través de la peste.

En septiembre de 2014 encontraron en alguna carretera de Tenosique el cadáver de un migrante cuyo cuerpo "había explotado", según relataron algunos testigos. Los rumores advertían que había fallecido "por ébola", aunque los médicos diagnosticaron un sobrecalentamiento, producto de las altas temperaturas de la zona. Pronto se difundió el rumor de que "el ébola había llegado a Tenosique" en el cuerpo de ese migrante; era septiembre de 2014 y los medios de comunicación divulgaban abundante información sobre ese virus. Si el migrante no murió por ébola, no había de qué preocuparse: había sido el calor lo que "reventó" su cuerpo.

¿Podrían las epidemias constituir una ruta para producir teatro en la frontera, en torno al paso de los migrantes por Tenosique? ¿No son las epidemias fenómenos colectivos y corporales? ¿No son tránsitos, flujos infectos, trayectorias de la muerte, huellas de los cuerpos enfermos, de los rostros desencajados? Cuando el ébola estuvo cerca de Tenosique lo trajo un rumor, una palabra incierta, que se sustentaba en el cadáver de un migrante encontrado en la carretera, "reventado" según los médicos. Epidemia de las habladurías que se esparcieron por la ciudad, enfermedades del África repetidas miles de veces en los medios de comunicación, cuerpos que revientan y sangran. El calor de la zona no podía explicar esos eventos, tan parecidos a los que describía la televisión. Pestes mediáticas que buscan evidencias en cadáveres anónimos tirados en una carretera fronteriza. ¿No hay es- 
pectáculo en el rumor, en esa crueldad chismosa y una preocupación vaga? ¿Cómo llegan esas enfermedades 'africanas' a Tenosique? ¿Por qué las traerían los migrantes, como si tuvieran que viajar en otros cuerpos para encontrar a los ciudadanos sedentarios, temerosos e inquietos? ¿Por qué viene de fuera lo que amenaza a ese adentro aparente que sería una comunidad o una sociedad local?

Antonin Artaud, en su famosa relación entre peste y teatro, escribe:

[...] así como las imágenes de la peste, en relación con un potente estado de desorganización física, son como las últimas andanadas de una fuerza espiritual que se agota, las imágenes de la poesía en el teatro son una fuerza espiritual que inicia su trayectoria en lo sensible y prescinde de la realidad (El teatro 28).

Imágenes de la peste: un cuerpo que ha explotado pero se desconoce la causa, una desorganización física mortal; un cuerpo deshecho, sus órganos colapsados y rastros de sangre en su superficie. ¿Qué inicia ante esa imagen?, ¿qué "fuerzas espirituales” se agotaron en ese cadáver?, ¿podría empezar una poesía que comience su trayectoria en lo sensible y prescinda de la realidad?, ¿significaría prescindir del cadáver en este caso?, ¿qué sería lo sensible y qué lo real?

La etnografía llegaría a reconstruir los hechos, a escuchar las versiones, a seguir el rumor, a conversar con los médicos, a revisar los archivos y las imágenes. Iniciaría, tal vez, su trayectoria en lo sensible (el cadáver) para conocer lo real (la muerte). ¿Qué haría el teatro? Empezaría en el cadáver (lo sensible), pero podría prescindir de la realidad (la muerte); rodearía al cuerpo de otras poéticas que no fueran las médicas o las forenses, las mediáticas o las políticas. El teatro podría generar otra peste mediante rumores, suscitar otras imágenes, desplazar los cuerpos y regresar al cadáver (que no termina de significar, que se descompone pero que nunca deja de existir al estar rodeado lo irresuelto; es el único testigo de esos parajes africanos donde la gente muere de ébola delante de las cámaras de televisión).

Supongamos que el migrante ha muerto de ébola y que la enfermedad ha llegado desde muy lejos en el cuerpo de un nómada; ¿podría el teatro dotar de "fuerza espiritual" a esta llegada de lo lejano y distante, envolver el temor de imágenes y de otros rumores, sacralizar el cadáver como un vestigio de los extensos viajes de los virus y la pequeñez del mundo? La etnografía termina donde empieza el arte. El ébola es un rumor falso para el etnógrafo; para el dramaturgo/actor es el inicio de lo sensible, el sostén de la imaginación. Enfermedades lejanas, cadáveres expuestos, rumores temerosos, medicina y burocracias, necropsias. Nada ha terminado ahí, aunque el cadáver haya desaparecido en una fosa común. Las habladurías aún lo blanden; en algún sentido, lo velan. África esparcida en virus, otros mundos trans- 
formados en rumores y desmentidos. Duelos por cadáveres desconocidos, pero también por las efímeras protecciones de la lejanía; lo insospechado arriba a este lugar; los terrores globales se transforman en rumores locales. Los cuerpos expuestos son como peregrinos de todas las enfermedades, de todos los males, de los horrores que deseamos evitar pero que tememos. El cadáver del migrante es testigo de que todo está muy cerca.

Artaud dice que "si admitimos esta imagen espiritual de la peste, descubriremos en los humores del apestado el aspecto material de un desorden que, en otros planos, equivale a los conflictos, a las luchas, a los cataclismos y a los desastres que encontramos en la vida" (El teatro 29). Si el teatro puede descargar sobre el espectador las fuerzas de ese desorden como una epidemia — siguiendo a Artaud—, ¿debería renunciar al cadáver y quedarse con los rumores?, ¿exaltar las enfermedades?, ¿desbaratar la versión de los médicos y reafirmar ese texto anónimo que anuncia la llegada de la peste (el ébola) a las puertas de la ciudad? A diferencia del etnógrafo que trabaja con la veracidad de los hechos y no puede hacer nada de eso - aunque se interesara en los rumores y creyera en las mentiras-, para el teatro no se trata de asentar una verdad; el objetivo pudiera ser convertir la peste en un acontecimiento que deje ver el desorden, los cataclismos y las luchas.

El ébola, ese mensajero trasatlántico, viene de los países centroamericanos a los que la población negra llegó deportada del África para trabajar en las plantaciones, a falta de suficiente mano de obra indígena, también esclava (ver Leiva Vivas, Tráfico de esclavos). ¿No podría leerse esta llegada inesperada y temida como un regreso de hechos pasados, de antiguos desórdenes que aún no se han resuelto, de conflictos vivos aunque opacos, de viejas luchas que subsisten? El teatro podría saltar las cadenas de evidencias que sostendrían una interpretación etnográfica, lanzándolas al aire como una nueva cartografía de las desgracias y los humores, de las pestes que son como momias en sarcófagos históricos y biológicos, que vuelven a levantarse de sus tumbas y salen a recorrer el mundo del que fueron apartadas. Como si África regresara a las rutas esclavistas repartiendo la enfermedad y la muerte; un África fantasmal, saturada de conflictos y luchas, que horada los cuerpos y une lo que parecía distante, que viene a cobrar sus deudas en estos territorios de haciendas y plantaciones, de esclavos y amos.

Tenosique está cerca de todo eso, pero parece darle la espalda y desconocerlo. Sirvió de puerto para las exploraciones de la Selva Lacandona, abasteció las monteras que utilizaban mano de obra indígena semi-esclava y endeudada (ver De Vos, Oro verde). Los troncos de los bosques centenarios de caobas y otras maderas preciosas bajaron por el Usumacinta hasta Tenosique, donde fueron contados y clasificados y luego siguieron su curso hasta la desembocadura del río, para ser llevados a los puertos de Europa y Estados Unidos. En esas bodegas se fueron miles de árboles y miles de vidas: los frutos abundantes de la tierra y la corta vida de la gente. Viejos lazos se crearon - cuyos rastros podríamos 
seguir - entre la densa oscuridad de la selva y esos puertos industriales, ciudades del capitalismo triunfante e imperial que explotaba las lejanías para producir los nuevos bienes que se creaban en las metrópolis.

Es desde esas lejanías - el África esclava- que arriba el ébola, la peste, recordando que el desorden permanece, que las plantaciones han sido cosechadas por esclavos y que también los árboles fueron serrados por esclavos. La memoria de la esclavitud no se disuelve: en el cuerpo de un migrante muerto, mensajero de epidemias, regresan de pronto los viejos conflictos, las luchas seculares.

¿No es todo esto lo que habría que descargar con la fuerza de una epidemia sobre los espectadores, para que fueran contagiados de esas luchas y esos conflictos que siguen vigentes y, en muchos sentidos, continúan siendo propios? El teatro, se lamenta San Agustín, produce en un pueblo "las más misteriosas alteraciones" (Artaud, El teatro 29). "Ante todo - escribe el francés - importa admitir que al igual que la peste, el teatro es un delirio y es contagioso" (30).

Se podría reemplazar ébola por teatro, recuperar las herencias de los rumores y reconstruir los conflictos y las luchas. El teatro velaría el cadáver del migrante, pero no desmentiría los rumores en torno a su muerte. Los rumores son la reactivación de ese desorden que aún aflige al presente, no constituyen mentiras sino verdades trastornadas y trastocadas. Corresponde al teatro producir una nueva línea de epidemias históricas, otras cartografías para la opresión y la memoria que trasfieran, de la mano de epidemias fantasmas, las esclavitudes reales. Que traigan de regreso a los barcos desde los puertos imperiales hasta la desembocadura del Usumacinta y los árboles a las húmedas montañas de la selva; que restituyan las vidas de los esclavos y resuciten al migrante muerto en una carretera, su cuerpo reventado por el calor infernal y los largos trayectos que deben recorrer los centroamericanos para adentrarse, desde la frontera con Guatemala, en territorio mexicano, a pie y evadiendo a la policía y autoridades migratorias. La etnografía carece de métodos de resurrección; es una ciencia de muertes definitivas.

El teatro debería "resucitar a los muertos" y no sólo hacer su duelo. ¿Cómo resucitar cuerpos? Acaso podríamos resucitar sus deseos, que son los últimos rastros de vida de esos cuerpos. Resucitar los deseos para salvarlos de la muerte...

La etnografía se pregunta por el futuro inmediato de los hechos y puede revisar un espectro más o menos amplio de su pasado. Puede seguir las líneas políticas, económicas o míticas. Llega hasta donde puede establecerse cierta claridad e inteligibilidad. El teatro empieza donde no se puede decir más, en la impotencia de la palabra y la memoria, y avista estrategias de resurrección. El duelo puede ser el inicio un camino, pero no necesariamente el único ni el final. La resurrección debe tocar, finalmente, al deseo. Se debe resucitar el deseo. 
INVESTIGACIÓNTEATRAL

Revista de artes escénicas y performatividad

Vol. 9, Núm. 13

abril-septiembre 2018
Figuras del límite: Documentos, etnografía y teatro

Rodrigo Parrini

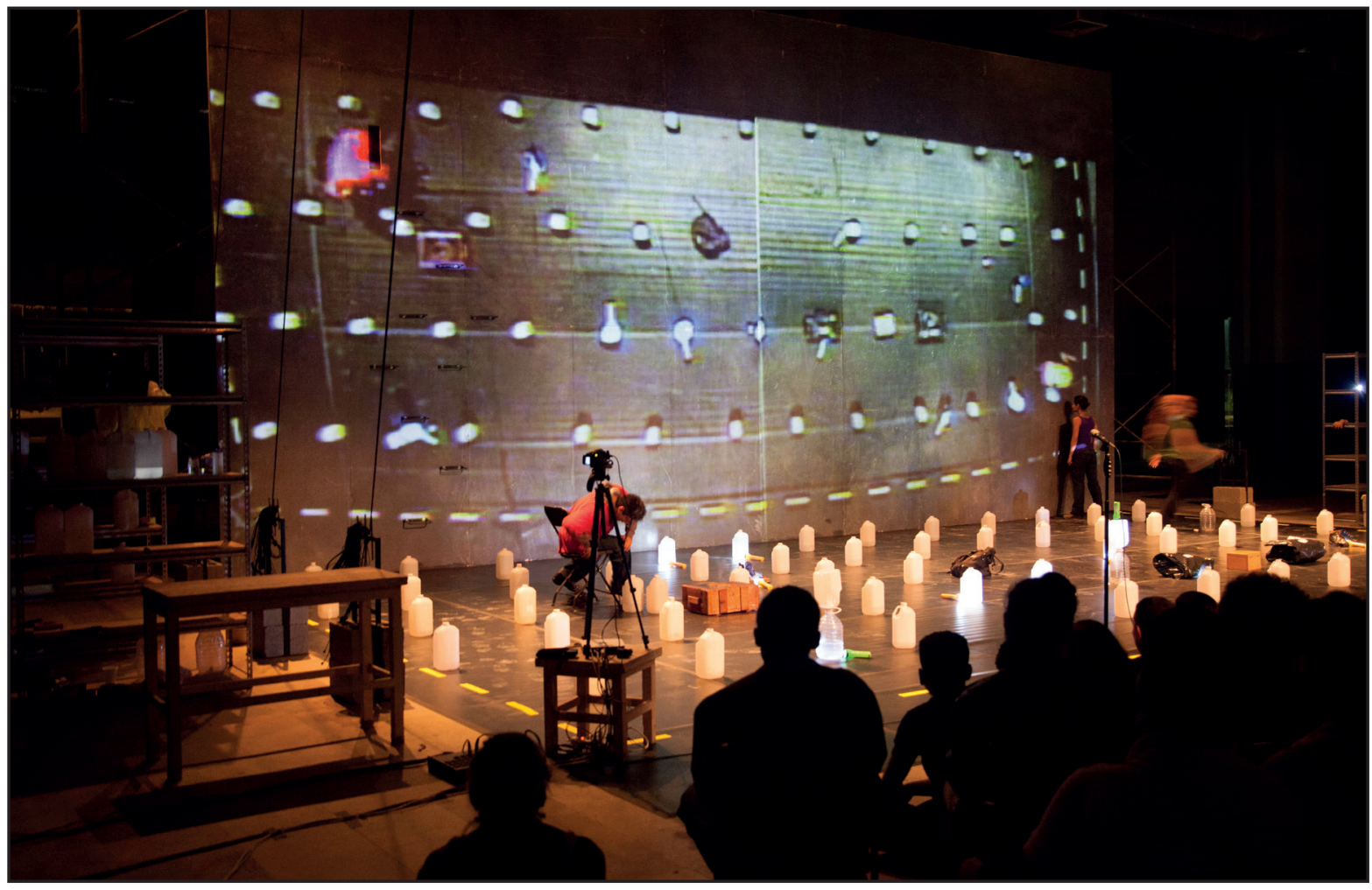

Escenografía de Amarillo. Tenosique, México, 2013. Fotografía de Marina España

\section{Segundo límite: la muerte y la soberanía}

En noviembre de 2013, Teatro Línea de Sombra montó en Tenosique su obra Amarillo, ${ }^{9}$ dedicada a la migración. Era un movimiento paradójico, porque la pieza estaba construida con relatos y materiales de la migración que atraviesa la frontera norte de México y se adentra en los desiertos de Estados Unidos. Mientras que la ficción ocurre en un lugar donde impera la arena, la puesta en escena se presentó en un lugar lleno de agua, una antigua selva tropical. La escenografía fue imponente: un muro oscuro de 12 metros de ancho y 8 metros de alto; era una transposición de la frontera norte en la frontera sur.

9 El texto explicativo que escribió la agrupación sobre la representación dice: "Un hombre ha partido y no se sabe nada de él. Amarillo, Texas, es el destino al que nunca arribó. Una mujer en la distancia reconstruye su cuerpo, su identidad, su probable itinerario y un discurso imaginado del ausente... Ese hombre y esa mujer tienen múltiples rostros, cientos de miles de identidades que conforman la imagen de un pueblo en éxodo continuo que se vacía lentamente" (TLS parr. 1). 
INVESTIGACIÓNTEATRAL

Revista de artes escénicas y performatividad

Vol. 9, Núm. 13

abril-septiembre 2018
Figuras del límite: Documentos, etnografía y teatro

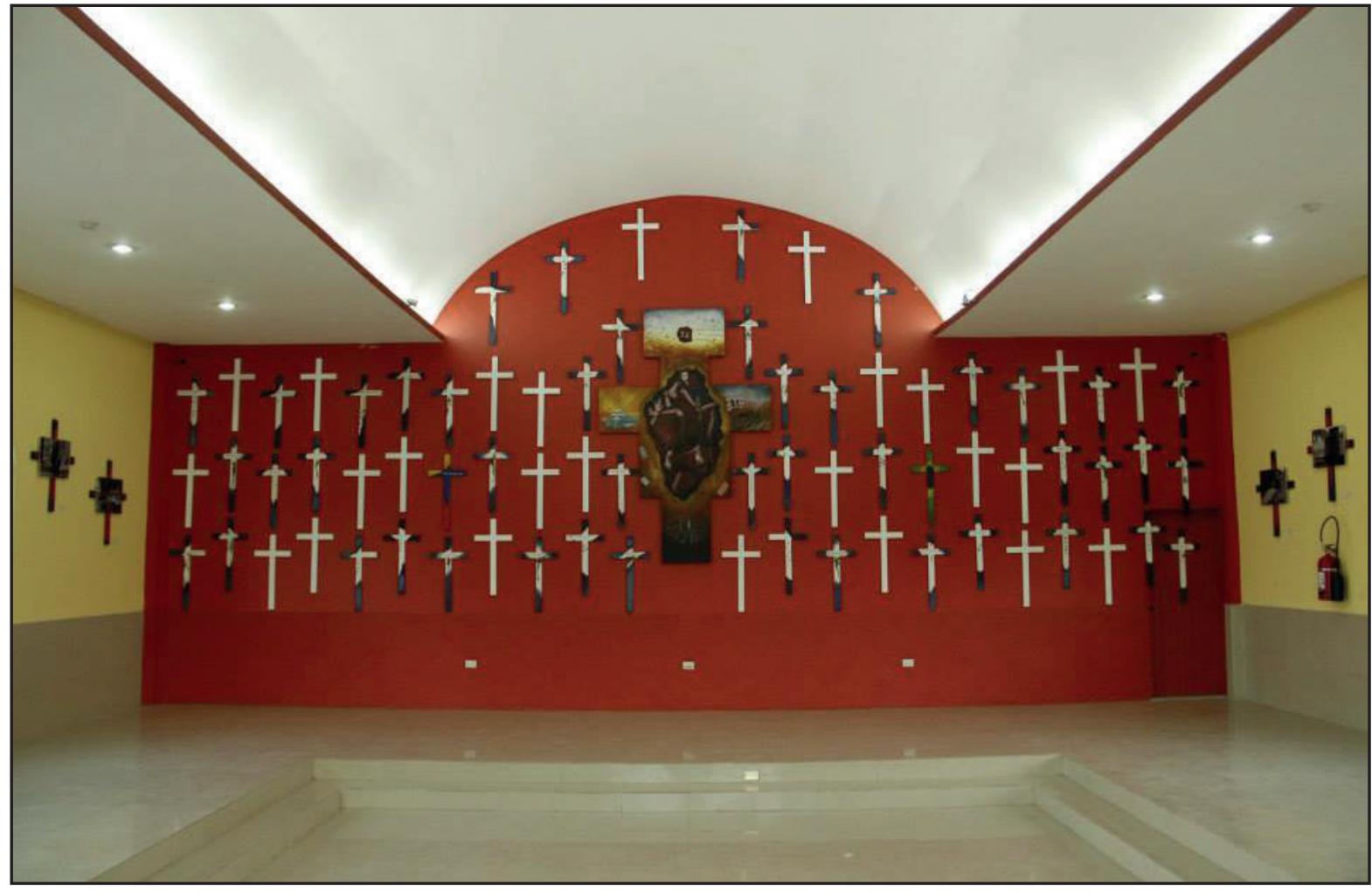

Muro norte, Capilla "La 72”. Tenosique, México, 2014. Fotografía de Rodrigo Parrini.

TLS construyó un muro en el límite y levantó una pared en la frontera, creando entonces un oráculo: el muro en 2013 era un obstáculo de la frontera norte; en 2015, ya lo era también de la frontera sur. ¿Cómo pudo el teatro adelantarse a los hechos?, ¿acaso puede funcionar como un oráculo? Creo que parte de la respuesta reside en su capacidad de mover signos y actos.

La política traza relaciones posibles, reales, entre signos y actos; por su parte, el teatro traza relaciones imaginables y en ese momento se transforma en una máquina de adivinar, no el futuro de las burocracias y las racionalidades, sino el de los actos o las vidas. TLs instaló un muro y produjo su evidencia. Lo soñó de algún modo y le otorgó una materialidad futura.

Los cuerpos figurantes del teatro anuncian los cuerpos documentados del mundo. El migrante-figural expone al migrante-in/documentado. En ese borde surge un límite. Las figuras del límite son diagramas, no individualidades; son máquinas, no identidades.

Por otra parte, en la pared norte de la capilla del Hogar-Refugio para Migrantes "La 72, hay setenta y dos cruces que recuerdan a los viajantes masacrados en San Fernando, 
Tamaulipas, en 2010. El muro es un panteón y un espacio conmemorativo: setenta y dos cruces para igual número de vidas. Dicha pared mira hacia el norte, una frontera violenta e impune donde fueron asesinados aquellos migrantes (casi todos centroamericanos). Nuevamente surge de allí un aparato predictivo, un anuncio: quien mira esas cruces también ve un destino posible. No han sido sólo setenta y dos, han sido tal vez miles los migrantes muertos en su paso por México.

Dos muros: el que levantó provisionalmente TLS y que miraba hacia el sur, aunque representaba las coordenadas espaciales y militares de la frontera norte de México, y un cementerio vertical permanente, también confrontando al norte. Dos límites y dos figuraciones, la muerte y la soberanía. El muro soberano del teatro que se levanta para impedir el paso de los migrantes y que contiene el relato de la pieza teatral; el muro mortuorio del Hogar que conmemora la muerte injusta de migrantes, anónimos en su mayoría. La soberanía es un muro vacío pero gigantesco; la muerte, una pared plagada de cruces.

Dos horizontes y dos oráculos que dicen lo mismo de formas diversas. El muro del teatro que anuncia el desierto y la sequedad; el muro de la capilla que profetiza la muerte y el crimen. Dos miradas pétreas sobre una frontera lejana que visibilizan el futuro de los cuerpos. En ese momento, los cuerpos líricos de los muros se entrelazan con los cuerpos (in)documentados de los migrantes. Las cruces son los objetos líricos de la muerte; el muro, oscuro documento de las soberanías estatales. Las cruces documentan el cuerpo lírico de los muertos y su anonimato; los muros del teatro, el espacio lírico del desierto y la persecución.

Creo que sería difícil saber dónde empieza el arte en estos deslindes, si en las cruces o en la pieza teatral, en los muros desunidos o en los relatos convergentes de ambas intervenciones. Ambos volúmenes son lenguajes, materialidades que profetizan.

Antonin Artaud escribe que "no hablamos para hacernos comprender, sino tan sólo en el interior de nosotros mismos; con un hierro de angustia, con el filo de una obstinación encarnizada, invertimos, desnivelamos el pensamiento" (El arte 106). Invertir el pensamiento es colgarlo como la figura del tarot, darle vuelta e inaugurar esa mirada de cabeza. Pero también podría implicar levantar el pensamiento como se levantan esos muros, extenderlo verticalmente para corretearlo por las alturas. Los muros son aquí inversiones, lo hemos dicho: una frontera por otra, cruces conmemorativas por muertes reales.

El muro de TLS es su propio documento: oscuro, vacío, inmóvil. En cambio, el muro de "La 72" es una especie de cuadro barroco sin espacios vacíos que sólo soporta las cruces. Muro lírico, figuras del límite, parcas oscuras o brillantes y excesivas, mortuorias o políticas.

La etnografía no levanta muros pero sí los puede documentar. Ir de uno a otro para trazar relaciones. En algún sentido, ella guarda la mirada de muros que se levantan o desaparecen, trabaja en medio de la evanescencia de los actos y de los acontecimientos para atestiguar su existencia y explicar sus razones. Etnografía mural que dibujará luego otras 
INVESTIGACIÓNTEATRAL

Revista de artes escénicas y performatividad

Vol. 9, Núm. 13

abril-septiembre 2018
Figuras del límite: Documentos, etnografía y teatro

Rodrigo Parrini

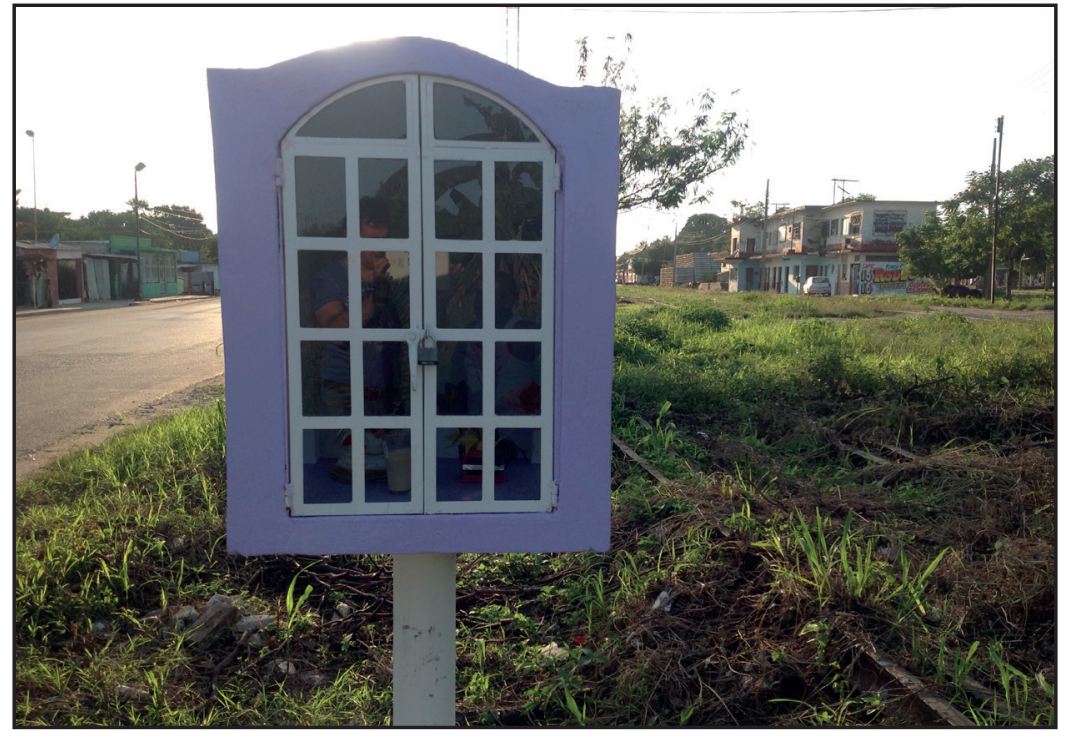

Nicho a las orillas del tren. Tenosique, México, 2014. Fotografía de Rodrigo Parrini.

coordenadas en la escritura. El muro que levantó TLS ya no está en el lugar donde fue construido. Cuando yo acababa de conocer "La 72", el muro norte de la capilla estaba vacío. Algo desapareció y también algo emergió.

Quisiera destacar los desplazamientos de los que somos testigos y que cuestionan ciertos marcos disciplinarios. El muro que levantó TLS corresponde a un deslizamiento poético de los lugares que se citan en la pieza: el muro tecno-policial que clausura la frontera norte, los migrantes muertos en el desierto de Arizona. El muro de "La 72", por su parte, desplaza las muertes que han sucedido en otra ciudad hasta un edificio en Tenosique e inmoviliza la tragedia. Uno documenta ritualmente la masacre, mientras que el otro poetiza escénicamente la muerte y la pérdida. En algún sentido, ambos son muros conmemorativos que producen un documento de lo que se ha desvanecido o no ha sido registrado. ¿Qué sucedió con ese edificio aciago en el que fueron encontrados los migrantes asesinados? Son ruinas, lugares a los que nadie regresará. En esa medida, el teatro y la etnografía se entrecruzan para documentar las ruinas y poetizarlas, para crear artefactos de memoria que sirvan, al menos, como diques para un proceso sociopolítico de eliminación de ciertos sujetos y destrucción de las huellas de la violencia.

\section{Tercer límite: el altar y la Bestia}

Cuando TLS estuvo en Tenosique, realizó una serie de intervenciones paralelas al montaje teatral. Una de ellas fue la construcción de un pequeño altar, un nicho, a las orillas del tren 
que cruza la ciudad. Unos albañiles hondureños edificaron el pequeño nicho y una vecina, que tiene un negocio a la orilla de las vías del tren, donó una imagen de la Virgen de Guadalupe. El altar se encuentra casi al lado de las vías férreas y a unos metros de la estación de trenes abandonada.

Al tren que pasa por Tenosique le llaman La Bestia. Hoy, La Bestia corresponde a la compleja red ferroviaria que cruza México de sur a norte, aunque en primer lugar fue el nombre del tren que transita específicamente entre Chiapas y Oaxaca.

Si el muro de TLS es una figura de la soberanía estatal, es posible señalar ahora a La Bestia como otra figura igualmente soberana. Podemos diferenciar, aparte, entre un muro soberano y estatal (el de la pieza teatral), frente a otro sagrado y religioso (el de "La 72", conmemorativo de las masacres de migrantes que han sucedido en México). Se trata de la misma superposición que ocurre paralelamente entre el altar con una Virgen a las orillas del tren, bordeando el paso de La Bestia.

No puedo explicar esos entrecruzamientos, pero, a mi entender, está en juego un proceso histórico de largo alcance que produce enigmas como los que acabo de mencionar. ${ }^{10}$ Agamben definirá a la nuda vida como una "zona de indiferencia y de tránsito permanente entre el hombre y la bestia, la naturaleza y la cultura" (Homo Sacer I 141). Las figuras del límite que hemos explorado son todas figuras de la nuda vida: zonas de indiferencia y tránsito entre lo humano y la bestia (la peste, la muerte, la masacre). La nuda vida surge en ese entrecruzamiento de coordenadas quizás inesperadas y diversas. La peste y el teatro, el teatro y la muerte, los muros y las masacres, los altares y los trenes... son los mapas del abandono, umbrales líricos y documentales de la violencia.

Artaud afirma que el único valor del teatro es "su relación atroz y mágica con la realidad y el peligro" (El teatro 101). Una zona indiferenciada que es posible poetizar sin eludirla: la realidad y el peligro es documentada por la etnografía, mientras que el teatro tiene posibilidades de imaginarla y conmoverla. Por eso la relación de este último con la realidad es atroz y mágica, como escribe el francés, mientras que para la etnografía sólo puede ser atroz porque la magia no le está permitida, salvo como objeto de estudio. El etnógrafo no puede operar mágicamente - esto es, líricamente- sobre la realidad para producirla de otro modo; puede documentar el peligro pero no abordarlo con la imaginación. Si la etnografía fuera el documento, el teatro sería la lírica, retomando la distinción de Didi-Huberman. El problema que me concierne es que nada de lo que aquí investigo es completamente documental o totalmente lírico; esos espacios y fenómenos son más bien híbridos.

10 Profundizo estos análisis en Parrini, Deseografías. 
INVESTIGACIÓNTEATRAL

Revista de artes escénicas y performatividad

Vol. 9, Núm. 13

abril-septiembre 2018
Figuras del límite: Documentos, etnografía y teatro

Rodrigo Parrini

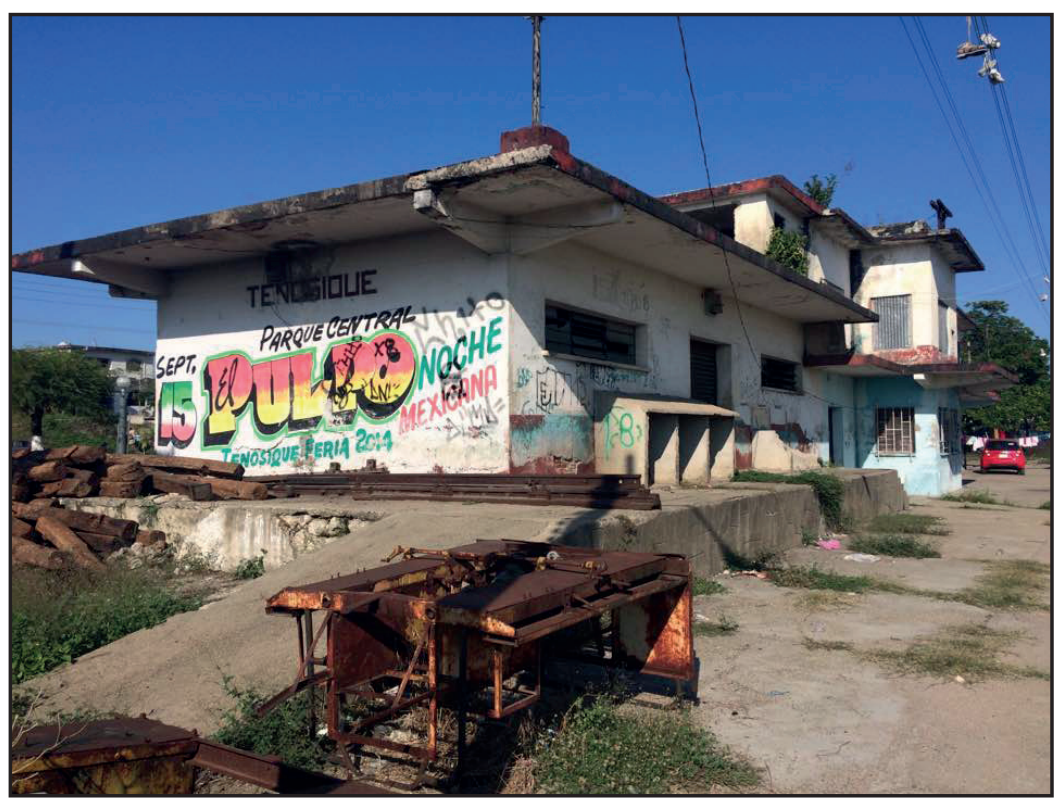

Estación de trenes.

Tenosique, México, 2014.

Fotografía de Rodrigo Parrini.

Me acerqué al teatro porque había encontrado un límite en mi propio trabajo de investigación: registrar las líricas cotidianas mediante procedimientos documentales. Si bien eso era posible en cierta medida, el elemento más intenso de esas líricas se perdía; por ejemplo, el momento más deslumbrante de las figuras del límite: cuando La Bestia pasaba a 50 kilómetros por hora, enorme y ruidosa, intensa y metálica, a la orilla de la imagen de una Virgen pequeña y discreta alojada en un nicho. En ese instante surge la figura del límite, pero no se puede registrar etnográficamente. Puedo dar cuenta de los hechos como lo hago aquí, pero no de su poder estético, de su profundidad histórica, de su urgencia política. Las bestias y las vírgenes necesitan de otros lenguajes. La nuda vida debe ser rodeada de otras imágenes, de líricas que la vistan, como se visten las vírgenes o se cubren los muros de recuerdos, de anuncios o verdades.

El nombre que se le puso al tren, ¿no es un modo lírico de dar cuenta de un problema político? La intervención de TLS al colocar ese nicho con su Virgen, buscaba producir otras liminaridades en el espacio indefinido de las líneas del tren; un terreno deshabitado y hostil que divide a la ciudad. La imagen de la Virgen, no obstante, produce otras líneas: verticales, dadas las topologías divinas del catolicismo; pero también radiales, porque hay otras imágenes cerca de ella: la vecina que donó la pequeña figura vive a una orilla, "La 72" está a menos de 300 metros del lugar... Las vías del tren atraviesan la ciudad de norte a sur y el tren se desliza por ellas. La Virgen traza líneas verticales de conexión divina desde la quietud del nicho. La antigua estación de trenes está deshabitada y derruida; la Virgen habita una 
pequeña habitación transparente. A veces, a las orillas de las vías del tren duermen algunos migrantes. Los recintos del estado en ruinas; una imagen religiosa alojada en un cuarto de cristal y concreto; los migrantes a la intemperie. La intervención de TLS abre una serie de interrogantes sobre las habitabilidades y la durabilidad de los lugares y las experiencias. Es llamativo que lo más efímero, pero también precario, esté del lado de los migrantes. La Virgen ¿no es también una estrategia lírica para confrontar la vulnerabilidad estructural de esos sujetos? La etnografía puede documentar esas intervenciones, las relaciones complejas en las que se insertan, pero también las densidades simbólicas y espaciales que producen. Un documento sobre la producción lírica del mundo.

Cuando Fray Tomás González, director de "La 72", inauguró y bendijo el nicho construido por TLS, dijo que el lugar donde estaba emplazado era un "territorio del mal", porque ahí secuestraban a los migrantes y en casas vecinas funcionaban redes de tratas de personas, que participaban de la explotación criminal de ese sector. Sus palabras, lacerantes y sonoras, se esparcieron entre los asistentes y la hierba que crece en esos terrenos. La Virgen había sido bautizada por el clamor político de un fraile que denunciaba la injusticia, cercana a todos los que participábamos en la bendición. Él hablaba en nombre de Dios y, en esa medida, podía interpelar directamente a La Bestia que cruzaba esos parajes, reeditando viejas escenas de la soberanía estatal. En alguna medida, ese pequeño recinto no documentaba la fe de los migrantes sino la brutalidad de su experiencia. El director de "La 72" desplegaba una retórica de la denuncia que articulaba, en torno a La Bestia -esa figura poética de las máquinas y las mercancías, de la violencia y los desplazamientos-, la relación enormemente compleja entre los aparatos del estado, los deseos de las multitudes (migrantes) y las formas micropolíticas de solidaridad y amparo que servían como refugio y contrapeso ante la violencia y el abandono.

No sabría decir si ese excedente discursivo y estético que produjo la intervención fue recopilado por TLS e integrado a sus dramaturgias y estrategias artísticas. Me parece que el teatro, comparado con la etnografía, cuenta con pocas estrategias de documentación. Tampoco se percibía un interés en registrar todo eso, como si lo que el arte producía no consiguiera integrarse al arte mismo y se deslizara hacia el olvido o la insignificancia.

Seguí durante varios años el destino de ese nicho. Alguna vez prendieron velas, lo que indicaba que tal vez se estaba transformando en un lugar de culto. Luego se comenzó a deteriorar. La vecina que había regalado la Virgen la rescató y la puso en su casa. En algún momento de 2016, tiraron la pequeña construcción y el nicho desapareció por completo. Estos hechos, las ruinas que produce una intervención artística, sólo interesan a la etnografía. El destino del nicho no inquietaba a TLS, aunque no era sólo su suerte lo que estaba en juego; también se trataba del destino del arte. Donde termina el teatro, empieza la etnografía. 
Al conceptualizar lo que denomina un "arte relacional", Nicolas Bourriaud escribe que:

La posibilidad de un arte relacional -un arte que tomaría como horizonte teórico la esfera de las interacciones humanas y su contexto social, más que la afirmación de un espacio simbólico autónomo y privado- da cuenta de un cambio radical de los objetivos estéticos, culturales y políticos puestos en juego por el arte moderno (Estética relacional 13).

La intervención de TLS se localizaba en ese campo. ${ }^{11} \mathrm{Si}$ fuera cierto que el arte puede tomar en cuenta "la esfera de las relaciones humanas y su contexto social", tendría que considerar sus efectos. ¿Qué sucede con esos horizontes relacionales que rompen con la inscripción mercantil del arte, pero que también abren otras interrogantes sobre sus propuestas políticas? Bourriaud se pregunta: “QQué es una forma cuando está sumergida en la dimensión del diálogo? ¿Qué es una forma que sería relacional en su esencia?” (Estética relacional 21). ¿El nicho es una forma? La imagen de la Virgen, ¿no es un "rostro que nos mira", en palabras de Serge Daney?; ¿cuáles son las relaciones que inauguran?, ¿qué diálogos?

\section{Lo posible y lo imaginable}

$\mathrm{El}$ arte, escribe Bourriaud en otro texto, obtiene su fuerza "circulando libremente en el universo del producto y del desperdicio, constituyendo a la vez un resto y un valor" (Bourriaud, La exforma 140). Para mí, ese circuito de lo intercambiable y lo inservible, lo valioso y lo desechable, lo entero y lo fragmentado, también es el campo de una antropología que trabaja en espacios y con sujetos liminares. La he llamado, en otra parte (Parrini, Falotopías), una antrapología: una práctica etnográfica materialista que se hace cargo de recolectar desechos de distinto tipo y reflexionar colectivamente sobre ellos. El etnógrafo es un pepenador (hermoso término náhuatl que significa recoger) no en tanto guarda cosas, sino porque trabaja entre desechos y desperdicios, con los colectivos desplazados y residuales. Una antrapología participaría de lo que Bourriaud denomina "un

${ }^{11}$ La intervención fue diseñada e implementada por el artista visual Alfadir Luna, que formó parte del Seminario de Medios Múltiples dirigido por José Miguel González Casanova; una de las instancias que ha promovido el arte relacional en México. Su principal trabajo se desarrolla en los mercados públicos de la Ciudad de México, en los que interviene ciertos diálogos y procesos de gestión colectiva para propiciar un ritual sui generis que vincula distintos mercados del Centro Histórico de la ciudad. 
ámbito de lo exformal: el lugar donde se desarrollan las negociaciones fronterizas entre lo excluido y lo admitido, entre el producto y el residuo" (11). Ese ámbito se interesa por todo signo "transitando entre el centro y la periferia, flotando entre la disidencia y el poder" (ibid).

En ese interregno se localizaron las intervenciones de TLS y también la reflexión que he elaborado en este artículo. Para el arte contemporáneo, la distinción entre un trabajo documental y otro lírico está caduca. No así para la etnografía, aunque el documento no sea un dato objetivo ni lo lírico una creación inspirada. Un documento - por ejemplo, el nicho des(h)echo a la orilla del tren - también guarda un potencial lírico que forma parte de su propio carácter documental. No es posterior a él ni añadido. La Virgen de las orillas era un documento visual y poético. Pero la etnografía es una disciplina de las oscilaciones, de modo que puede documentar el momento o el modo en que una propuesta lírica (nicho, obra, fotos) se transforma en un documento.

En ese sentido, esta práctica de investigación se mueve entre lo posible y lo imaginable. No es una disciplina de los hechos solamente, sino también de las ficciones que dan forma a un mundo. En esa medida, el teatro surge como un aliado conflictivo que le permite potenciar lo imaginable y cuestionar lo posible. Si el documento fuera un registro de lo posible, lo lírico sería otro de lo imaginable.

\section{Bibliografía}

Agamben, Giorgio. Homo sacer I. El poder soberano y la nuda vida. Trad. Antonio Gimeno. Valencia: Pre-Textos, 2006.

Artaud, Antonin. El arte y la muerte / Otros escritos. Trad. Víctor Goldstein. Buenos Aires: Caja Negra, 2005.

Artaud, Antonin. El teatro y su doble. Trad. Enrique Alonso y Francisco Abelenda. Madrid: Edhasa, 2001.

Bourriaud, Nicolas. La exforma. Trad. Eduardo Berti. Buenos Aires: Adriana Hidalgo, 2015.

Bourriaud, Nicolas. Estética relacional. Trad. Cecilia Beceyro y Sergio Delgado. Buenos Aires: Adriana Hidalgo, 2013.

Descola, Philippe. "On anthropological knowledge”. Social Anthropology, vol. 13, núm. 1, 2005, pp. 65-73.

De Vos, Jan. Oro verde. La conquista de la Selva Lacandona por lo madereros tabasqueños, 1822-1949. México: Fondo de Cultura Económica, 1996.

Didi-Huberman, George. Pueblos expuestos, pueblos figurantes. Trad. Horacio Pons. Buenos Aires: Manantial, 2014. 
Fábregas Puig, Andrés. "El concepto de frontera: una formulación". Fronteras des-bordadas. Ensayos sobre la frontera sur de México. Coord. Alain Basail Rodríguez, México: Ediciones Casa Juan Pablo, 2005, pp. 21-52.

Haraway, Donna. Testigo_Modesto@Segundo_Milenio.HombreHembra@_Conoce_Oncoratón ${ }^{\circ}$. Feminismo y tecnociencia. Trad. Helena Torre. Barcelona: Universidad Oberta de Catalunya, 2004.

Ingold, Tim. "Anthropology is Not Etnography". Proceedings of the British Academy, vol. 154, 2008, pp. 69-92.

Jodorowsky, Alejandro. Psicomagia. Madrid: Siruela, 2004.

Jodorowsky, Alejandro y Marianne Costa. La vía del Tarot. Trad. Anne Hélène Suárez. México: Grijalbo, 2004.

Leiva Vivas, Rafael. Tráfico de esclavos negros a Honduras. Tegucigalpa: Secretaría de Cultura, Artes y Deportes, 1982.

Nader, Laura. "Ethnography as theory". HAU: Journal of Ethnographic Theory vol. 1, núm. 1, 2011, pp. 211-219.

Parrini, Rodrigo. "Canto de palomas. Teatro de animales y etnografía del espacio”. Cartografías Críticas. Comp. Ileana Diéguez, vol. II. Los Ángeles: Ediciones Karpa, en prensa.

Parrini, Rodrigo. "Cuerpos figurantes, cuerpos incircunscritos. Un carnaval migrante en la frontera sur de México". Lo complejo y lo transparente. Investigaciones transdisciplinarias en ciencias sociales. Comps. Eva Alcántara, Yissel Arce y Rodrigo Parrini, México: Universidad Autónoma Metropolitana, Xochimilco, pp. 69-98, 2018.

Parrini, Rodrigo. Deseografías. Una antropología del deseo. México: Universidad Autónoma Metropolitana, Xochimilco, Centro de Investigaciones y Estudios de Género, UNAM, 2018.

Parrini, Rodrigo. Falotopías. Indagaciones sobre la crueldad y el deseo. Bogotá y México: Instituto de Estudios Sociales Contemporáneos, Universidad Central y Centro de Investigaciones y Estudios de Género, UNAM, 2016.

Saskia Sassen. Expulsados. Brutalidad y complejidad en la economía global. Madrid: Katz, 2015.

Teatro Línea de Sombra. 2017. Teatro Línea de Sombra, en línea. Consultado el 19 de agosto de 2017.

Turner, Victor. The Ritual Process. Structure and Anti-Structure. Ithaca: Cornell University Press, 1991. 


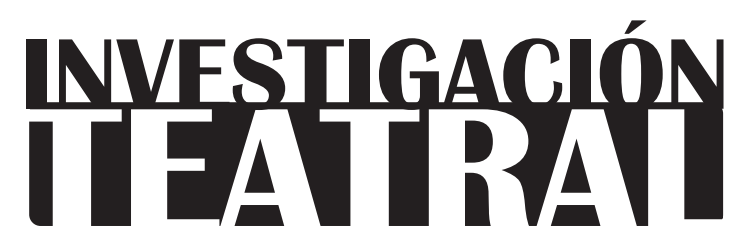

Revista de artes escénicas y performatividad

Vol. 9, Núm. 13

abril-septiembre 2018

Segunda época

ISSN impreso: 1665-8728

ISSN electrónico: 2594-0953

Universidad Veracruzana

\section{Cuerpo estigmatizado y enunciación paratópica en la performance de Lechedevirgen Trimegisto}

Antoine Rodríguez*

* Centre d'Etudes en Civilisations, Langues, et Lettres Etrangères, Universidad de Lille, Francia.

e-mail: antrodriguez52@gmail.com

Recibido: 30 de agosto de 2017

Aceptado: 28 de enero de 2018 


\title{
Cuerpo estigmatizado y enunciación paratópica en la performance de Lechedevirgen Trimegisto
}

\section{Resumen}

Este trabajo propone un análisis de la performance Pensamiento Puñal (2012) del artista mexicano Felipe Osornio "Lechedevirgen Trimegisto", tomando como punto de partida la noción de paratopía teorizada por el lingüista francés Dominique Maingueneau. Se reflexiona sobre varios aspectos de la creación de Lechedevirgen Trimegisto: la escenificación de la postura paratópica del creador —es decir, de su problemática inserción en el espacio sociocultural-, las filiaciones culturales que sirven de legitimación a la obra y la des-biopolitización del cuerpo masculino cuir/queer a la que se dedica el artista de performance.

Palabras clave: performance, paratopía, cuerpo, masculinidad, queer, México.

\section{Stigmatized Body and Paratopic Enunciation in the Performance of Lechedevirgen Trimegisto}

\begin{abstract}
This article discusses the performance Pensamiento Puñal (2012) of Mexican artist Felipe Osornio (a.k.a. Lechedevirgen Trimegisto), taking cue from the notion of paratopia, as theorized by the French linguist Dominique Maingueneau. Several aspects of Lechedevirgen Trimegisto's work are addressed: the staging of the artist's paratopic positioning (that is, of the problematic way in which he locates himself in the socio-cultural space), the cultural affiliations that serve as legitimation to his work, and the des-biopoliticization of the queer male body.
\end{abstract}

Keywords: performance, paratopia, body, masculinity, queer, Mexico. 


\section{Cuerpo estigmatizado y enunciación paratópica en la performance de Lechedevirgen Trimegisto}

$\mathrm{E}$ ncerrado en una habitación, con el cuerpo enfermo recuperándose de un herpes zóster que lo dejó inmovilizado varias semanas, Felipe Osornio (n. 1991) escribe, desde el dolor - "entre vómitos, sangrados nasales y mucho dolor" ("Pensamiento puñal, crítica", entrevista) - "Pensamiento Puñal", un texto poético-mágico que puede considerarse como una especie de manifiesto en el que Lechedevirgen Trimegisto (nombre artístico de Osornio) parece asentar las bases o líneas que van a orientar su obra performática. En dicho texto - escrito en noviembre de 2012, cuando Osornio tenía 21 años- el cuerpo estigmatizado, ${ }^{1}$ herido, adolorido, va a convertirse en herramienta epistemológica de resistencia política.

Una advertencia agregada por el autor al final del mismo, precisa: "Esto no es una 'Receta Política', se trata de un ejemplo acerca de cómo construir un pensamiento crítico y reflexivo. Esto no es una categoría sino un espacio de acción creativa y pánica. ${ }^{2}$ No po-

1 Entiendo la palabra "estigma" en el sentido que le da el sociólogo Erving Goffman (Stigmate), es decir, un atributo que desacredita profunda y socialmente a una persona. Hay tres tipos de estigmas. El primero tiene que ver con "la monstruosidad" o "deformidad" del cuerpo. El segundo se relaciona con lo que los otros perciben como "taras de carácter" ("falta de voluntad", "pasiones irreprimibles o antinaturales"). En cuanto al tercero, agrupa los estigmas "tribales" (raza, nacionalidad, religión) (13-14). Traducción mía, del francés.

2 Se refiere seguramente al Teatro Pánico, movimiento artístico fundado por el dramaturgo español Fernando Arrabal a principios de los años 1960. El Teatro Pánico también se basó en una especie de manifiesto, bajo la forma de una conferencia en la que Arrabal abogaba por un arte regido por una locura controlada frente a una sociedad en crisis de valores. 
drás devenir Puñal, pero sí podrás aPUÑALar el sistema" (Lechedevirgen, "Pensamiento Puñal" 20). La intención programática del texto es evidente: se trata de "construir" un cuestionamiento epistemológico ("un pensamiento crítico") en el marco de la creación artística del autor que se concreta en su elaboración performática (en el sentido de arte acción) y producir nuevos conocimientos sobre el cuerpo y la masculinidad. También es evidente la dimensión política: "apuñalar" metafóricamente "al sistema", significa deconstruir de manera radical las redes normativas de un poder hegemónico, o dicho de otra manera, cuestionar el carácter naturalizado de dichas normas explicitando su construcción y función culturales.

En el marco de este trabajo tomaré como punto de partida el texto "Pensamiento Puñal", que sirvió de base a la performance homónima del propio Lechedevirgen. ${ }^{3} \mathrm{Mi}$ propósito es reflexionar sobre varios aspectos de la creación de Osornio: la escenificación de la postura paratópica del creador (es decir, de su problemática inserción en el espacio sociocultural), las filiaciones culturales que sirven de legitimación a la obra y la des-biopolitización del cuerpo masculino a la que se dedica el performancero.

\section{Crear (desde) la paratopía}

En 2004, el lingüista francés Dominique Maingueneau publica un libro sobre discurso literario: Le discours littéraire: Paratopie et scène d'énonciation, en el que teoriza la noción de "paratopía", concepto que él mismo crea para dar cuenta de los procesos complejos que posibilitan y legitiman la emergencia de la creación de una obra literaria y su inserción en el campo literario. Pero además de su aplicación en el campo literario, el concepto se puede extender a cualquier proceso creativo y particularmente a la propuesta performática de Lechedevirgen que, en el caso de Pensamiento Puñal, se fundamenta justamente con la elaboración de un texto literario cuya función es ser objeto de una realización de arte acción.

La paratopía es la paradójica situación del escritor que no puede situarse al exterior de la sociedad ni tampoco en el interior de la misma (Maingueneau, Le discours littéraire 52), quedando condenado a elaborar su obra a partir del carácter radicalmente problemático de su propia pertenencia a la sociedad. Su enunciación se constituye a través de tal imposibilidad de asignarse un verdadero lugar. La paratopía es entonces una localización para-

3 Este texto también fue utilizado por el performer mexicano Lukas Avendaño en su acción titulada Crimen organizado, que pude ver en el marco del Primer Foro de Teoría Queer de la Universidad Veracruzana (7 de noviembre de 2013). 
dójica: no es ausencia de lugar, sino una difícil negociación entre el lugar y el no-lugar, una localización parasitaria (ibid.). No se trata, como en el caso de la "heterotopía" foucaultiana (Foucault, "Des espaces autres") de una representación o de una subversión de un espacio real que admitiría la superposición de varios espacios incompatibles (como el cine, el teatro o el cementerio, según los ejemplos que da Michel Foucault), sino de posibilitar, en el marco del acto creativo, una ubicación dentro de un espacio determinado del que el artista queda, no obstante, excluido.

El artista es a la vez el impuro (el "inmundo", fuera del mundo) y la fuente de todo valor; el paria y el genio, según la ambivalencia del término latín sacer, maldito y sagrado (Maingueneau, Le discours littéraire 78). La paratopía es un proceso que sólo se puede considerar a través de su enunciación discursiva; no hay, precisa Maingueneau, situación paratópica extra-literaria. Es, a la vez, aquello de lo que hay que liberarse a través de la creación y aquello que la creación ha de elaborar; lo que da la posibilidad de acceder a un lugar y lo que prohíbe toda pertenencia espacial (Maingueneau, "Quelques implications"). A través de su obra y en un mismo movimiento, el escritor debe resolver y preservar una imposible pertenencia. Crear significa producir una obra y construir al mismo tiempo las condiciones que permitan producirla. Toda paratopía significa, por lo menos, la pertenencia y la no-pertenencia, la imposible inclusión en un lugar (topos). La paratopía aleja ya sea de un grupo (paratopía de identidad), de una ubicación (paratopía espacial) o de un momento (paratopía temporal).

La paratopía de identidad (familiar, sexual o social) ofrece todas las figuras de la disidencia y la marginalidad, literal o metafórica: "mi grupo no es mi grupo". De cierta manera, y particularmente en el caso de producciones de artistas pertenecientes a minorías sociales, sexuales o étnicas (como es el caso de Lechedevirgen), hay una posible articulación entre el concepto de paratopía y el de "desidentificación”, teorizado por el crítico cubano-estadounidense José Esteban Muñoz (desidentification) y aplicado también al análisis de performances latinoamericanas queer. Partiendo de los aportes teóricos del lingüista francés Michel Pêcheux, Muñoz concibe el concepto de "desidentificación" como una manera de:

describir las estrategias de supervivencia que pone en práctica el sujeto que pertenece a una minoría con el fin de negociar con una esfera fóbica mayoritaria que todo el tiempo acalla o castiga la existencia de sujetos que no se ajustan al espectro de la ciudadanía normativa ("Introducción a la teoría” 557).

La desidentificación es, pues, una manera de negociar (o de jugar) con(tra) la ideología dominante. Consiste en negarse a asimilar dicha ideología sin tampoco rechazarla totalmen- 
te, o "reciclar y repensar un significado codificado" que permita, a partir de los elementos de la codificación hegemónica, "representar una política o postura, privada de su fuerza, que la cultura dominante convirtió en algo impensable" (595). La desidentificación es un proceso paratópico en la medida en que supone una identificación parcial y atípica con los códigos dominantes, por ejemplo cuando un varón homosexual se identifica, no con un varón masculino, sino con una estrella de cine femenina.

Por su parte, la paratopía espacial es la de los exilios ("mi lugar no es mi lugar”, "en cualquier lugar donde esté, no estoy en mi lugar”), mientras que la paratopía temporal se fundamenta en el anacronismo: "mi tiempo no es mi tiempo", ya sea en el modo del arcaísmo o de la anticipación: se es sobreviviente de una época pasada o ciudadano prematuro de un mundo venidero (Maingueneau, Le discours littéraire 86-87).

La situación paratópica de Lechedevirgen se enuncia y se escenifica desde el principio de "Pensamiento Puñal":

Escribo desde el filo de la tierra, desde el fin del mundo, el borderline de los últimos tiempos.

Desde las heridas, desde las grietas, las cortaduras de un imperio fracasado, desde el espacio místico y ambiguo del cuartomundo, desde el cut-up intertextual de las postidentidades, porque ahora que me lees, esto soy: texto.

Escribo para aquellxs que son el target, [...] subordinadxs a los márgenes, teniendo terror a los baños del colegio [...].

Para aquellxs que dar en el blanco significa una amenaza irónica, pues son de todos los colores menos el blanco. Cuerpos ocupados, desde la sala de operaciones abstracta, en el parto, líquido amniótico y sangre de madre, hasta el paredón, el ghetto, la cárcel, el hospital, apedreadxs, insultadxs, escupidxs, rechazadxs: impotentes.

Para aquellxs que un mal día se dieron cuenta que llevan cara de indio, tez de estiércol, lxs que odiaron su cuerpo, para lxs pocohombres, lxs mariachis, lxs que constituyen un atentado a la masculinidad hegemónica, directa o indirectamente, lxs que son culpables de lo que no cometieron, culpables de llevar el pecado en la carne y vivir la penitencia. (Lechedevirgen, "Pensamiento Puñal" 14)

Palabras y expresiones como "el filo de la tierra", "desde el fin del mundo", "borderline”, "últimos tiempos", "subordinadxs a los márgenes", "paredón", "ghetto" y "cárcel” van configurando un campo léxico de lo periférico y de la exclusión, un paradigma semántico que señala, entre otras cosas, una problemática inclusión en la sociedad. A la paratopía espacial se superpone la paratopía de identidad, es decir, el hecho de ser rechazado por tener como estigma corporal "cara de indio", "tez de estiércol". Es, paradójicamente, a partir de esa mis- 
ma situación de exclusión enunciada como tal, que Lechedevirgen inscribe su obra en el campo cultural de la creación performática. La exclusión funciona como la condición de su inclusión en el campo cultural, pero sólo puede incluirse enunciando su situación paratópica de marginado social.

Para enunciar la paradójica inscripción de su obra, cada autor recurre, según Maingueneau (Le discours littéraire 95-96), a toda una gama de shifters paratópicos ${ }^{4}$ (embrayages en francés, deícticos en español), tales como el bohemio, el nómada, el vagabundo, la cárcel, el sanatorio, etcétera. En el texto de Lechedevirgen son varias las figuras que funcionan como tales shifters. A modo de ejemplo citaré unas cuantas: "lxs prostitutxs", "lxs desobedientes", "lxs esclavos a distancia", "lxs delincuentes", "lxs criminales", "niñxs chicleros", "putitos", "vestidas", “chichifos", “mariquitas", “jotas", “locas", “mayatones”, “machorras", “tortilleras”, "traileras", "operadas". Toda una lista de personajes que encarnan la marginación social por su condición socioeconómica, su disidencia frente a las normas sexuales hegemónicas o bien frente a las normas sociojurídicas. Personajes que se sitúan en la periferia de la vida social, pero a los que la obra de Lechedevirgen atribuye un lugar central. Entre ellos se halla la figura proteica y simbólica del "Puñal", cuyos contornos definitorios ocupan la mayor parte del texto.

La elección de la imagen del puñal se debe a su doble sentido: un sentido denotado, que remite al objeto que corta, y otro connotado, sinónimo despectivo de homosexual, que se relaciona en el imaginario popular mexicano con la idea de traición/transgresión, con el apuñalar/penetrar por la espalda. Pero en el texto, "puñal" - y el verbo correspondiente, "apuñalar" - se convierten sobre todo en herramienta o metodología epistemológica para cuestionar la producción coercitiva de la masculinidad hetero e incluso homonormada.

Si la escritura de "Pensamiento Puñal" se lleva a cabo, como Lechedevirgen lo ha precisado en varias entrevistas, ${ }^{5}$ en el encierro y la inmovilidad del cuerpo enfermo, su génesis parte de un fracaso social que se remonta a la niñez del autor y que se asocia a un fenotipo de "indio", conjugado con la imposibilidad de adecuarse a las normas de la masculinidad viril heteronormada:

4 Maigueneau parte de la definición lingüística de "shifter": "elemento que inscribe en el enunciado su relación con su situación de enunciación". En el caso del "shifter paratópico", se trata de elementos que participan a la vez del mundo representado por la obra y de la situación a través de la cual se instituye el autor que construye el mundo representado. Un ejemplo puede ser el submarino Nautilus de la novela de Jules Vernes Veinte mil leguas de viaje submarino, que constituye una cabina paratópica nómada y que revela una imposible inscripción espacial fija. Ver Maingueneau, Le discours littéraire 96.

5 Esto se ve, por ejemplo, en la entrevista titulada "Pensamiento puñal, crítica directa a las 'coreografías' sociales", publicada en La Jornada Jalisco. 
Tengo el cuerpo demonizado, encarno el fenotipo latino del delincuente, del coyote, del sicario, del traficante, del brasero [sic] [...], del judas, del traidor, del chamuco, incluso del sex simbol (Lechedevirgen, "Pensamiento Puñal" 16).

Soy Puñal [...] por ir en contra de la ley natural, del orden social y las buenas costumbres, por penetrarles el culo hasta que sangran. Por ser abyecto, por traicionar a mi patria, a mi gobierno, a los deseos de mi madre y mi padre, a la biología y la genética, a la academia y las pinches "Bellas Artes", al racismo, al clasismo y al sexismo, por decirle NO a ser un Macho (17).

El visible estigma del fenotipo indígena - que tiende a ser interpretado como señal de inferioridad social por las clases altas y medias mexicanas-, así como la debilidad y enfermad del cuerpo, una identidad no heterosexual y la doble disidencia frente a la masculinidad hegemónica y ante una homonormatividad gay, son los elementos paratópicos a partir de cuya enunciación y puesta en escena Lechedevirgen hace obra. Ahora bien, si por un lado su inclusión en el espacio sociocultural es posibilitada, como ya señalamos más arriba, a partir de la puesta en discurso de la exclusión, son otros, en cambio, los procesos que la legitiman. Por ejemplo, las diferentes filiaciones o inscripciones genealógicas que el autor selecciona en el archivo cultural "autorizado", es decir, productor de legitimación.

\section{Crear (desde) la filiación cultural}

El texto de Lechedevirgen convoca a toda una red cultural en la que convergen artistas e intelectuales canonizados o institucionalizados, así como figuras de la cultura de masas y de la cultura popular, con los que el autor establece una filiación explícita. Fuente de inspiración, marco teórico y estético, estrategia legitimadora de la obra, dicha red se constituye a través de una selección en el archivo cultural nacional e internacional. Conecta al artista con campos como los estudios queer/cuir, el feminismo chicano, el postporno, ${ }^{6}$ el arte contemporáneo, el teatro pánico, el surrealismo, el cine nacional que el autor maneja desde lo kitsch, la performance latinoamericana, etcétera. Los extractos siguientes precisan algunos de los nombres de estos artistas o movimientos estéticos:

${ }^{6}$ Según Beatriz Preciado, la pospornografía es "el proceso de devenir sujeto de aquellos cuerpos que hasta ahora solo habían podido ser objetos abyectos de la representación pornográfica: las mujeres, las minorías sexuales, los cuerpos no-blancos, los transexuales, intersexuales y transgénero, los cuerpos deformes o discapacitados. Es un proceso de empoderamiento y de reapropiación de la representación sexual" ("Entrevista con Beatriz Preciado", parr. 1). 
[Escribo] para lxs que quieren hacer una obra maestra, morir como Ana Mendieta, Unica Zürn o Fred Herko, saltar en el vacío (14).

Soy Puñal de colección, espécimen regional heredero de Chela Sandoval, de Jodorowsky de Arrabal y Topor, del Pánico, de Anzaldúa, de Melquiades, de Mago Melchor, de Gómez Peña, de la Congelada, de Paco X., de Giuseppe Campuzano, de Gurrola, de Semefo, de Polvo de Gallina Negra, entre muchxs otros. Heredero de la genética de Cantinflas, de Tin tán [sic], de Mago Septién, de Ramón Valdez y el profesor Jirafas, de Chinchín el tepor8 y Gabriel Retes, de los bultos en los pantalones ajustados de Pedro Infante y Jorge Negrete en plena movida cruising, de Agustín Lara y sus "dos puñales" de hoja dama-esquina-mezquina, de Macario y su pacto con la muerte a través de un pollo rostizado (16).

Por otra parte, y fuera de este texto-manifiesto, Lechedevirgen ha dado varias entrevistas (algunas de ellas grabadas y disponibles en internet, otras publicadas en revistas o periódicos electrónicos) en las que precisa sus diferentes filiaciones y herencias estético-teóricas. A los nombres citados en su texto, se pueden añadir los de Julia Kristeva y su teoría sobre la abyección, Teresa de Lauretis y sus aportes teóricos sobre lo queer, Paul B. Preciado (antes Beatriz Preciado) y su teoría sobre (trans)sexualidades. Las palabras recurrentes con las que Lechedevirgen define su práctica artística son: "Performance queer [o cuir] ${ }^{7}$ extrema”, "postporno", "arte contemporáneo", "arte extremo", "arte acción”. También insiste en la conexión de su obra con la alquimia, vista ésta como un proceso de transformación de la materia y el espíritu. La elección del nombre "Trimegisto" está directamente inspirada en la alquimia y viene a simbolizar un arte cuya función es la transformación del yo y del entorno (ToutVaBien TV, "Leche de virgen Trimegisto").

La inflación discursiva - a la que el mismo autor contribuye- en torno a los aspectos definitorios de su obra performática, contrasta con el rechazo radical de toda identidad respecto al género y al sexo. Lechedevirgen se inscribe en las teorizaciones queer (o cuir, según la reapropiación del concepto por cierta crítica latinoamericana $)^{8}$ de las post-identidades y de la deconstrucción de los binarismos sexo-genéricos. "Las identidades sexuales funcionan como camisa de fuerza", dice en una conversación ("Entrevista en compañía de Felipe Osornio"); para él son como "jaulas" en las que no sólo han metido a la gente, sino que la gente se ha me-

7 Como cito las palabras de un video, no sé si cuando Lechedevirgen dice "cuir", lo conceptualiza con la grafía "queer" o "cuir".

${ }^{8}$ Para más amplia información sobre la adopción del término cuir en vez de queer, y los debates a los que dio lugar en la crítica latinoamericana, ver el libro de Fernando R. Lanuza y Raúl M. Carrasco, Queer E Cuir. Políticas de lo irreal, 2015. 
tido sin darse verdaderamente cuenta de ello. La elaboración performática de Lechedevirgen parece hallarse en una situación paradójica en la que la deconstrucción de las identidades hegemónicas respecto a los cuerpos sexuados, pasa por una fuerte filiación identitaria a discursos autorizados que lo legitiman como portador de una contestación anti-identitaria.

Definirse contra la identidad, excluyendo toda definición, pero al mismo tiempo multiplicando las identidades disidentes y socialmente estigmatizadas, parece ser otro más de los rasgos paratópicos con los que Osornio hace obra.

\section{Des-biopolitizar el cuerpo masculino}

Uno de los logros de la modernidad y del capitalismo ha sido, como lo demuestra Foucault en la Historia de la sexualidad (1976), desarrollar dispositivos para ejercer un control disciplinario de los cuerpos y la sexualidad. El bio-poder, es decir, la politización de la "nuda vida" - término que utiliza Agamben en Homo sacer para referirse a los cuerpos vivientes-, ha tenido la capacidad y la función de crear cuerpos políticamente dóciles recurriendo a toda una serie de "tecnologías adecuadas" (Agamben 12). Uno de esos dispositivos es el sistema sexo/género (Rubin, "Léconomie"), responsable de una dominación masculina que se manifiesta socialmente ya no sólo a través de la docilidad de los cuerpos, sino mediante la opresión contra las mujeres, la misoginia, la violencia contra los homosexuales y contra todo cuerpo transgresor de las normas sociales del género.

El corpus performático de Lechedevirgen gravita predominantemente sobre la formación y los efectos de la masculinidad mexicana hegemónica. Violencia de género, machismo, misoginia, homofobia, así como nacionalismo coercitivo, racismo y clasismo, son los temas que el artista escenifica para deconstruirlos. Dicha deconstrucción, que hay que entender como un cuestionamiento a la naturalización coercitiva de normas culturalmente construidas, se concreta en el espacio performático por toda una serie de combinaciones metafóricas de objetos (la introducción de un puñal en el ano, quemaduras de cigarro, agujas clavadas en la piel de la frente, entre otras) que abordaremos fugazmente más adelante. El artista pone en juego y arriesga su propio cuerpo, un cuerpo mestizo, "aindiado", que acarrea físicamente los estigmas de una nacionalidad y una masculinidad de segunda clase. Un cuerpo que, por exhibir su exclusión del marco normativo de la masculinidad hegemónica, es percibido e interpretado - según las normas de la masculinidad mexicana dominante, basada en la figura del macho- como el cuerpo de un hombre fallido. Como apunta el investigador Antonio Prieto Stambaugh ("Corporalidades políticas"), desde la década de 1990 el cuerpo se convierte en un espacio textual, "una piel transformada en pergamino diseminador de interrogantes" (609), que lleva los signos materiales del ejercicio violento del poder, la colonización y/o el color 
de una pertenencia étnica despreciada. El performer Guillermo Gómez-Peña lo expresaba así: "Nuestra principal obra de arte es nuestro propio cuerpo, impregnado de implicaciones semióticas, políticas, etnográficas, cartográficas y mitológicas" (495). Él plantea que los cuerpos de las minorías sexo-étnicas-sociales son "territorios ocupados", que el performance es capaz de someter a un proceso de descolonización (498).

De manera menos frecuente, el cuestionamiento de Lechedevirgen se vuelca también sobe la normatividad de los hombres gay: masculinos, consumistas, normatividad percibida igualmente como generadora de exclusión y violencia simbólica. Como señala Prieto Stambaugh, este artista celebra "lo cuir no desde una idealización color de rosa que domestica la diferencia, sino desplegando cuerpos performáticos de a-normalidad des-generada" ("El eros politizado" 37).

Si partimos de la premisa según la cual la configuración y los efectos de una masculinidad mexicana dominante, misógina, homofóbica y altamente violenta ha sido incorporada, voluntaria o involuntariamente, por la mayoría de los hombres a través de un proceso de biopolitización de sus cuerpos - es decir, a través de tecnologías de subjetivación y de socialización institucionalizadas como las de la familia, la escuela o la iglesia-, entonces podemos considerar que la deconstrucción a la que se dedica Lechedevirgen consiste en des-biopolitizar el cuerpo masculino, valiéndose para ello de diversos recursos textuales y escénicos.

\section{Crear (desde) el texto}

El contenido textual de "Pensamiento Puñal" hace explícitos los efectos violentos y naturalizados del sistema sexo/género (o patriarcado) a través de un lenguaje que combina abstracciones, insultos y metáforas:

[...] el régimen de mierda de dominación patriarcal occidentalista del hombre blanco, rico y heteronormativo (16).

[Soy Puñal] por no ser un "hombre hecho y derecho", por no procrear sino crear, por no golpear mujeres, por no matar jotitos, por no saber manejar o andar en bicicleta, por negarme a reproducir sus sistemas de control sobre mi cuerpo y la vida. Por ser antagonista, anti-héroe, escoger ser el fuego en lugar de Prometeo. Por ser la serpiente y no el águila. Ponzoñosa punzocortante (17).

En tanto adopta el tono y función de un manifiesto estético, el texto ofrece también orientaciones sobre la escenificación del cuerpo performático y particularmente del cuerpo del autor. Estas indicaciones escénicas son particularmente interesantes porque señalan al 
cuerpo como herramienta epistemológica que contribuye a des-biopolitizar la masculinidad para re-politizar el cuerpo:

Mi cuerpo es el arma más poderosa [...], la agencia Puñal comienza por penetrarse el recto con el mango de un cuchillo de carnicero, dando el culo al aire, rasgando el cielo, amenazante, y termina por navajearse el abdomen atlético, tenso, sangrante. Soy Puñal y herida. Penetrador y penetrable. Cuerpo lleno de bordes, de filos, de fisuras y de surcos. Una cartografía de suturas y cicatrices, paisaje de carne dividido por líneas imaginarias y táctiles, interseccional, transfronterizo, subalterno [...]; mi cuerpo vacío y sin órganos, mi cuerpo explícito, desollado. [...]. Porque la verdadera penetración es la que rasga el cuerpo, perfora el tejido y se clava donde no hay agujero. Soy Puñal por lo obsceno (en escena) de mis cortes y superficies sangrantes, porque soy "actor" (pos)porno, porque soy cuerpo atrapado en lo (caleidos)escópico (16-17).

El cuerpo enunciado textualmente, que luego va a ser expuesto en el espacio performático, es el cuerpo del subalterno mexicano des-masculinizado y des-heterosexualizado que toma la palabra, la encarna y se exhibe desde la abyección y la obscenidad, entendida ésta como lo que no hay que mostrar por considerarse, según la etimología del término, "fuera de escena". Es un cuerpo abierto, agrietado, herido, sin las fronteras o los límites impuestos al cuerpo masculino hegemónico; un cuerpo penetrador y penetrable que convierte la angustia masculina heteronormada de ser penetrado en estrategia de des-biopolitización. ¿En qué consiste esta des-biopolitización? Principalmente en poner el cuerpo - y "el culo"- estigmatizado en escena, si no con la pretensión de liberarlo completamente de las normas de la masculinidad, al menos sí para mostrar las grietas, tropiezos y fallos de su construcción biopolítica.

De cierto modo, el acto transgresor de exponer un cuerpo "obsceno" es un acto de revelación. Se trata de revelar lo que la biopolitización de los cuerpos ha dejado precisamente "fuera de escena". Si el arte performático admite un desarrollo político-discursivo como lo hace el texto "Pensamiento Puñal", grabado y difundido durante la presentación escénica, su esencia estética está en lo (audio)visual y en la puesta en escena del cuerpo del performancero.

\section{Crear (desde) el espacio performático}

La videograbación de la versión 2012 de la performance Pensamiento Puñal, disponible íntegramente en internet (aunque no provoca las mismas reacciones y apreciaciones que el acto en vivo, ya que recurre a las codificaciones del lenguaje fílmico), informa, no 
INVESTIGACIÓNTEATRAL

Revista de artes escénicas y performatividad

Vol. 9, Núm. 13

abril-septiembre 2018
Cuerpo estigmatizado y enunciación paratópica en la performance de Lechedevirgen Trimegisto

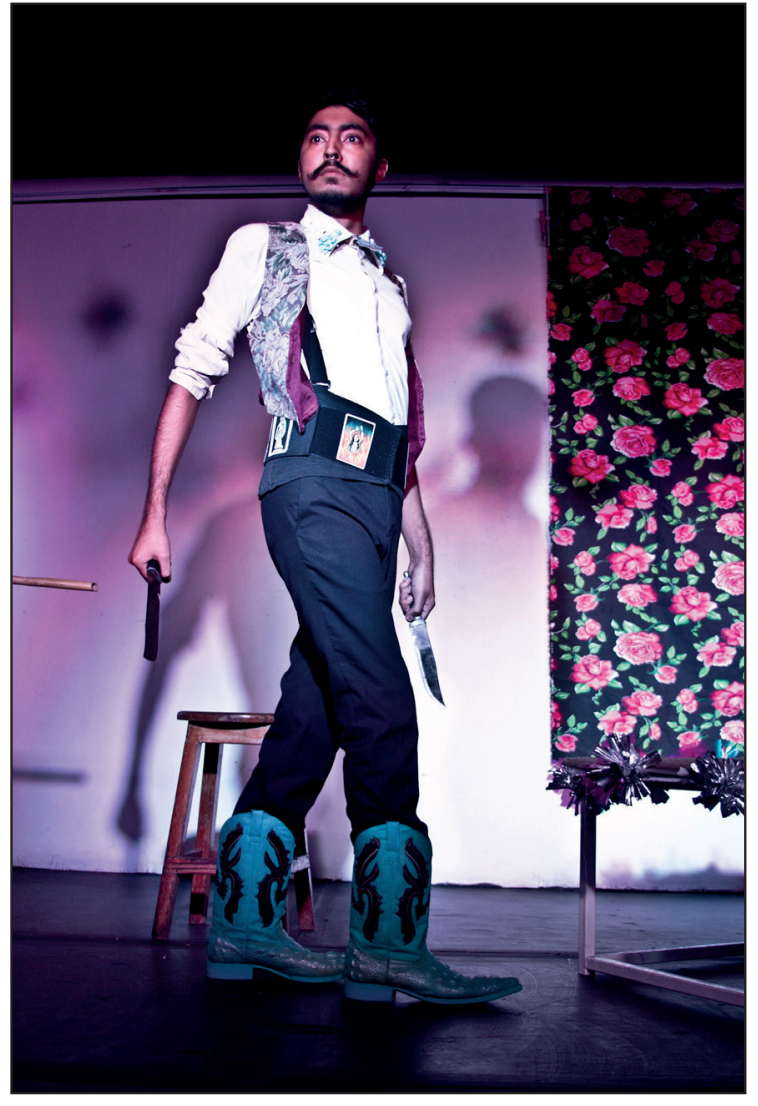

Antoine Rodríguez
Lechedevirgen Trimegisto en el performance Pensamiento Puñal. Festival Internacional de Performance "Extra!", Centro Cultural Xavier Villaurrutia. Ciudad de México, 2013. Fotografía de Herani Enríquez Amaya "HacHe”.

obstante, sobre las elecciones escenográficas y la gestión del cuerpo en el espacio performático (las imágenes incluidas aquí son de una presentación realizada en 2013). Lo primero que llama la atención es la importancia que el artista concede a los numerosos elementos escenográficos y a la banda de sonido omnipresente durante toda la performance. Sería imposible mencionar todos los elementos en el marco de este trabajo, así que elegiré solamente algunos que resultan pertinentes para dar cuenta tanto de la polisemia que brota de la obra, como de la empresa de deconstrucción a la que se dedica el artista.

La performance comienza con un sonido de helicóptero o de temblor. En el espacio escénico se puede ver una especie de telón de fondo negro con impresiones de rosas que recuerda a los manteles populares. Lechedevirgen entra: lleva bigote, pantalones negros de piel, botas vaqueras verdes, camisa blanca, chaleco de flores y una especie de cinturón-faja con cartas del tarot. En la frente, sobre la parte superior de las cejas, lleva clavadas algunas agujas de jeringas, y a manera de cetro ostenta un caballito de palo, el juguete infantil 
INVESTIGACIÓNTEATRAL

Revista de artes escénicas y performatividad

Vol. 9, Núm. 13

abril-septiembre 2018
Cuerpo estigmatizado y enunciación paratópica en la performance de Lechedevirgen Trimegisto

Antoine Rodríguez

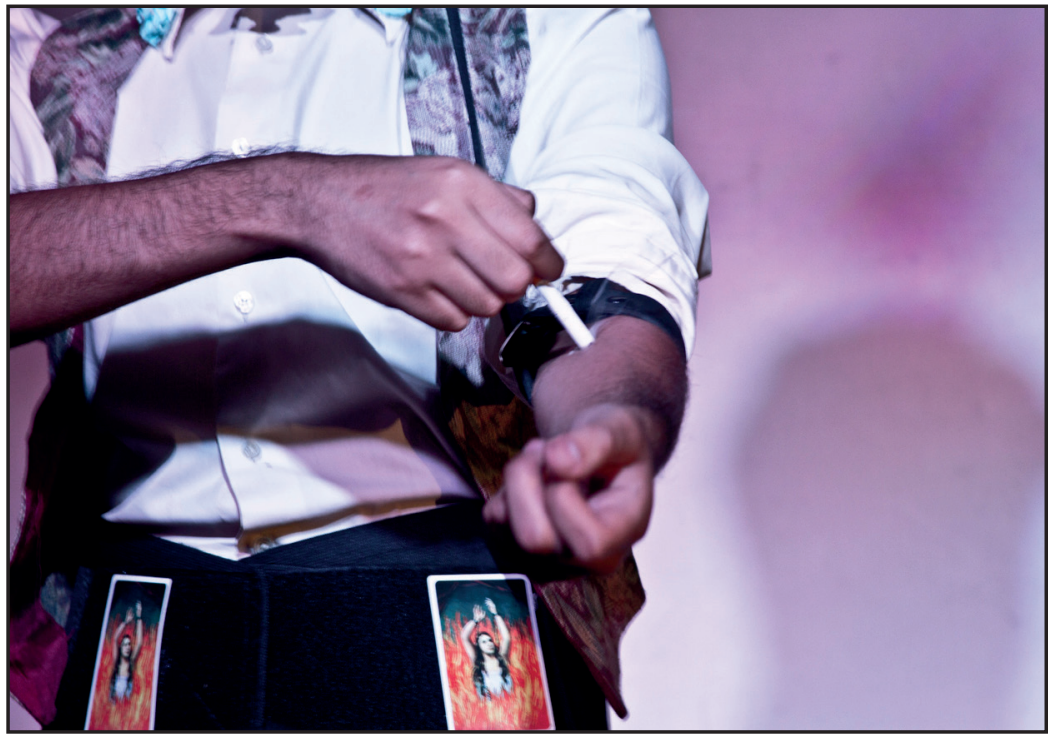

Lechedevirgen Trimegisto en el performance Pensamiento Puñal. Ciudad de México, 2013. Fotografía de Herani Enríquez Amaya "HacHe".

típico. Todos estos elementos van configurando un universo kitsch que no sólo posibilita un distanciamiento lúdico, sino además ejerce una fuerza estética seductora. No estamos en presencia de un hombre "hecho y derecho", sino de un individuo que acarrea algunos elementos de un simulacro de la masculinidad hegemónica. Éstos se mezclan, contradicen y contaminan paródicamente (por ejemplo, el bigote prototípico de virilidad se convierte en señal paródica). La parodia es, de hecho, una de las estrategias a las que recurre el performancero para des-biopolitizar la masculinidad hegemónica.

Otro proceso estético al que recurre Lechedevirgen es la construcción metafórica. Consiste en asociar dos o más elementos que en la realidad pertenecen a categorías diferentes, dotándolos de nuevos significados sin alterar el o los significantes de origen. Pondré dos ejemplos para ilustrarlo:

El performer se sienta, toma un cinturón con el que se ata un brazo como si fuera una goma de extracción de sangre. Enciende un cigarro, lo manipula como si se tratara de una jeringa y se lo clava encendido en el brazo. El cigarro es metafóricamente una jeringa, pero en esta transformación no ha dejado de ser un cigarro encendido. La metáfora convoca, por lo menos, dos imágenes y dos sensaciones: la jeringa que se clava en el brazo y la quemadura del cigarro; dos percepciones cuyo efecto refuerza la sensación de dolor. A su vez, otras imágenes posiblemente connotadas se superponen a esas: por ejemplo, escenas de tortura o violencia física. La metáfora funciona como un proceso de creación de imágenes y sensaciones polisémicas, polifónicas y enigmáticas que abren en el receptor múltiples interpretaciones y conexiones mentales. 
INVESTIGACIÓNTEATRAL

Revista de artes escénicas y performatividad

Vol. 9, Núm. 13

abril-septiembre 2018
Cuerpo estigmatizado y enunciación paratópica en la performance de Lechedevirgen Trimegisto

Antoine Rodríguez

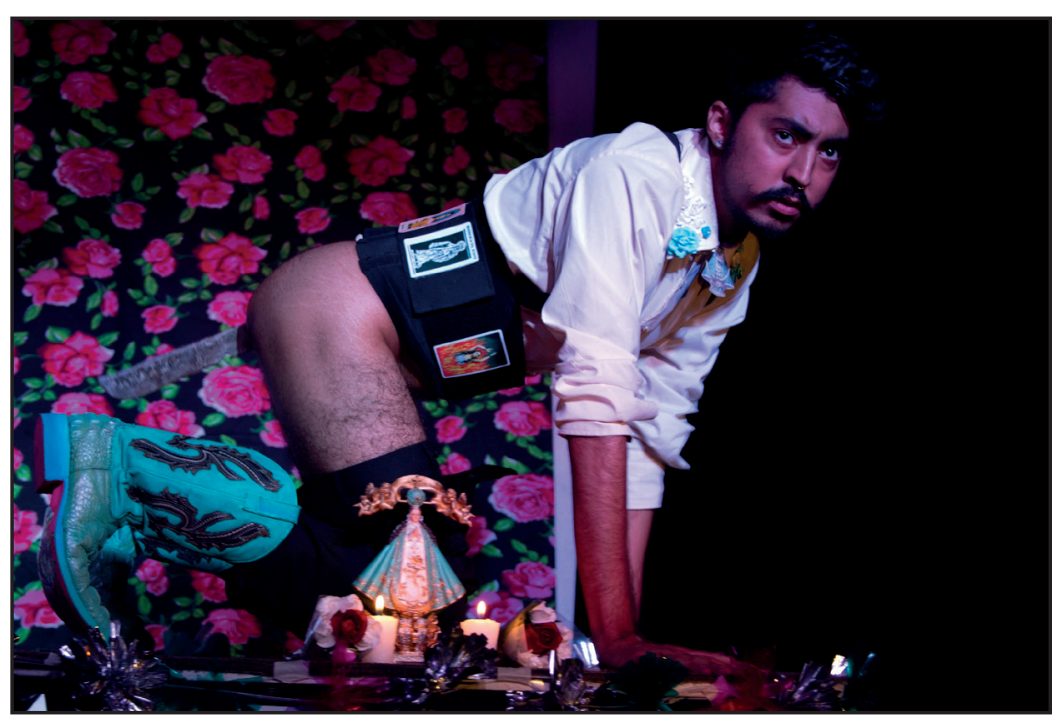

Performance Pensamiento Puñal. Ciudad de México, 2013. Fotografía de Herani Enríquez Amaya "HacHe".

El segundo ejemplo corresponde a otra secuencia en la que Lechedevirgen se introduce el mango de un puñal en el ano. El puñal que, como ya vimos, es también un sinónimo despectivo de homosexual, se convierte metafóricamente en pene erecto o dildo y remite a la sodomía, el tristemente famoso pecado nefando o contra natura, estigmatizado y condenado por la Santa Inquisición. Pero el objeto puñal no deja de ser tal, convocando las imágenes de herida o muerte que culturalmente se le asocian. Eros y Tanatos se reúnen de este modo en un mismo significante, que tiene la capacidad de convocar otros significados en asociación con el texto que se escucha en ese momento ("arma revolucionaria", "rifle en el ano en honor a Zapata", "goce sexual", "porno mariachi”). La imagen "extrema" de la sodomía efectuada en escena con un puñal pertenece al registro de lo habitualmente obsceno. Viene a perturbar no sólo las imágenes relacionadas con la masculinidad heteronormada, sino también las imágenes convencionales de una homosexualidad hegemónica que se practica en la intimidad o en espacios fuera de escena.

Pero quizá la secuencia más emblemática en cuanto al cuestionamiento estético de la masculinidad falocéntrica, sea aquella en la que Lechedevirgen, sentado en un taburete frente al público, simula cortarse los testículos con un puñal. ${ }^{9}$ La banda de sonido que

9 En 2010, el performer y filósofo puertorriqueño Bernat Tort, presentó un performance, On ne naît pas femme, on le devient, en el que se cubrió el rostro como mujer islámica y realizó con unas tijeras tres incisiones detrás de sus testículos. Con la sangre marcó tres páginas de los tres principales libros religiosos: el Corán, La Biblia y La Torá (Elnuevodia.com, "Habitar el cuerpo"). 
INVESTIGACIÓNTEATRAL

Revista de artes escénicas y performatividad

Vol. 9, Núm. 13

abril-septiembre 2018
Cuerpo estigmatizado y enunciación paratópica en la performance de Lechedevirgen Trimegisto

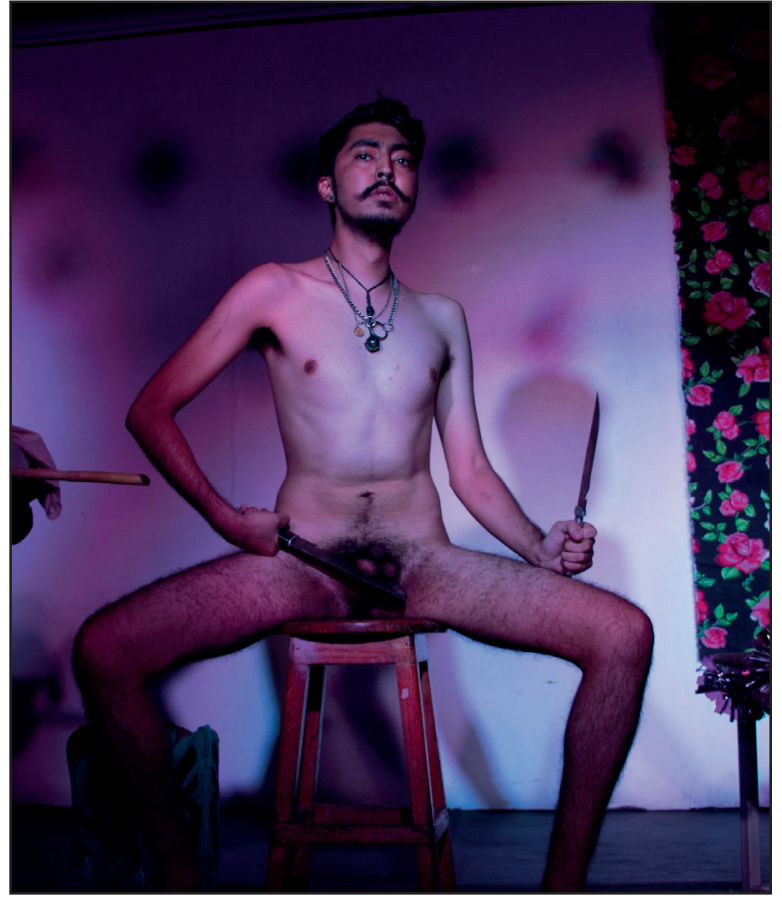

Performance Pensamiento

Puñal. Ciudad de México,

2013. Fotografía de Herani

Enríquez Amaya “HacHe”.

acompaña la escena va difundiendo un fragmento del texto "Pensamiento Puñal", cuya función es la de connotar las acciones, objetos y órganos exhibidos, en el proceso de significación metafórica ya aludido:

En el tarot las espadas simbolizan el lenguaje y el pensamiento, se trata pues de afilarse. No se trata de nombrarse Puñal, se trata de aPUÑALar, de volverse verbo, porque ante todo Puñal es acción en el mundo. Puñal no se conforma con la apropiación de la injuria, va más allá. Puñal se trata de un arma de doble filo, al tiempo que te haces daño, les haces daño [...]; se trata de afilarse cada borde del cuerpo, de ser repetitivo porque sólo así se saca el filo (19).

A partir de los significantes visuales (puñal, testículos, pene) la escena convoca y provoca varias imágenes y reacciones. Primero, una respuesta física, sensación dolorosa en el receptor, a la que le sigue una interpretación inmediata del acto de emasculación simulado. Cortarse los testículos viene a significar una voluntad de deshacerse del órgano que simboliza socialmente a la virilidad. Herirse es una manera de herir también al otro, o dicho de otro modo, deconstruir su propia masculinidad es una manera de deconstruir la masculinidad del otro. Pero en seguida el texto orienta la interpretación 
INVESTIGACIÓNTEATRAL

Revista de artes escénicas y performatividad

Vol. 9, Núm. 13

abril-septiembre 2018
Cuerpo estigmatizado y enunciación paratópica en la performance de Lechedevirgen Trimegisto

Antoine Rodríguez

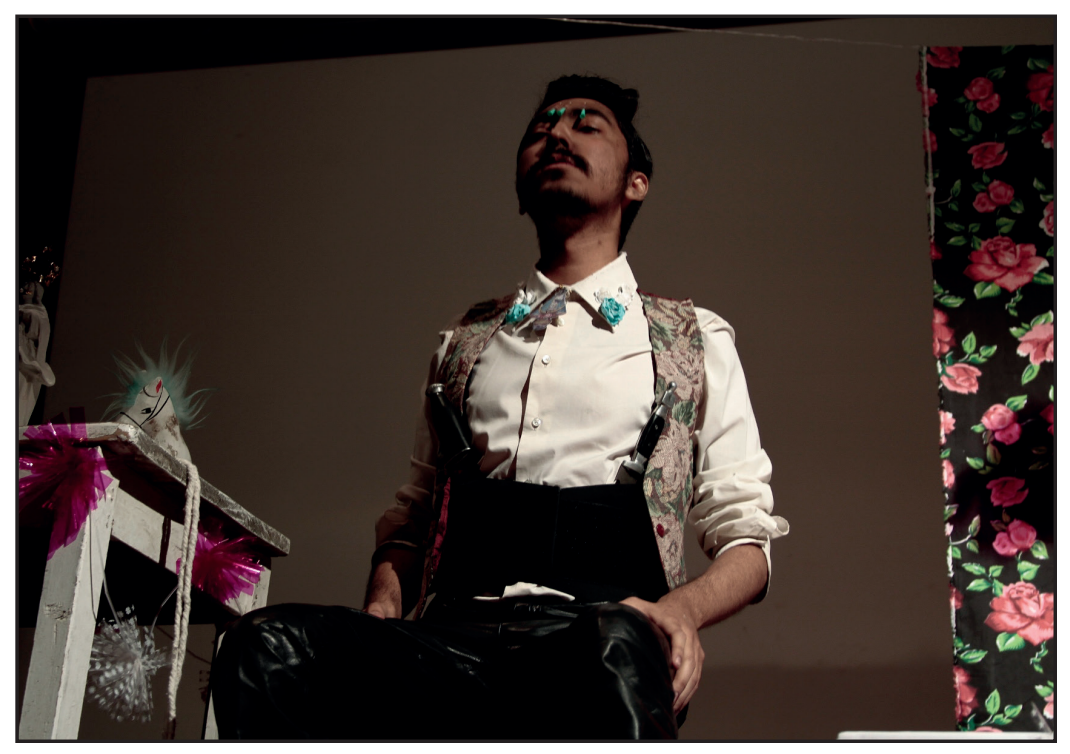

Performance Pensamiento

Puñal. Ciudad de México, 2013. Fotografía de Herani Enríquez Amaya "HacHe".

hacia niveles abstractos: el puñal pasa a ser metáfora de la espada que en el tarot simboliza al lenguaje. Ya no se trata, como habíamos leído en primera instancia, de cortarse los testículos sino de "afilarse" en el doble sentido de la palabra: sacar filo y aguzar el entendimiento. Se trata de cuestionar el lenguaje, portador de pensamiento, apropiándoselo y usándolo como arma de resistencia contra las construcciones simbólicas de una masculinidad coercitiva.

Podría multiplicar los ejemplos que ilustran las posturas estéticas de Lechedevirgen sin conseguir jamás abarcar las numerosas redes polisémicas de la obra. Es lo que hace de sus propuestas performáticas procesos creativos interesantes y fascinantes. Los cuestionamientos epistemológicos en torno a las normas de construcción del sistema de género y de la masculinidad en particular, se dan a través de la creación de imágenes que van más allá de una exposición discursiva. Convocan universos estéticos e imaginarios que tienen la capacidad de conectarse con las tramas y los traumas inconscientes del espectador, provocando fuerte adhesión o rechazo, pero también preguntas perturbadoras.

\section{Conclusión}

Felipe Osornio, alias Lechedevirgen Trimegisto, nace en 1991, al mismo tiempo que la incipiente teoría queer "blanca", introducida por Teresa de Lauretis ("Queer theory: Lesbian and Gay Sexualities"), Eve Kosofsky Sedgwick (Epistemogía del armario) y Judith Butler 
(El género en disputa). La teoría queer y los procesos de deconstrucción de las categorías identitarias relativas al sexo y al género, desestabilizan la naturalización de la sexualidad heterocéntrica, contribuyendo paralelamente a crear, dentro de las ciencias sociales, una especie de micro-episteme o marco epistémico que posibilita - y de cierto modo legitima- la emergencia de expresiones artísticas de inconformidad respecto a la formación de cuerpos valorados y prestigiados desde criterios hegemónicos de belleza, raza, clase o sexualidad. Lechedevirgen se inscribe en este movimiento teórico de deconstrucción, pero también se inspira en los textos teóricos del feminismo del Tercer Mundo estadounidense, tales como Borderlands / La Frontera de Gloria Anzaldúa, This Bridge Called My Back de Cherrie Moraga y Gloria Anzaldúa, o los textos de la chicana Chela Sandoval ("Feminismo cyborg"). Éstos ofrecen, desde antes de la teorización queer de los noventa, una reflexión sobre la situación de las mujeres de color atrapadas en redes de dominación debido no sólo a su género sino también a su clase social, orientación sexual y rasgos étnicos.

Lechedevirgen articula estos aportes teóricos con su inscripción artística en movimientos como el arte extremo (por ejemplo), que se vuelca a exhibir cuerpos y situaciones fuera de las consideraciones tradicionales de las bellas artes: cuerpos feos, deformados, heridos, enfermos, agónicos, monstruosos; prácticas obscenas, repugnantes o al límite de lo aguantable. El objetivo implícito parece ser, como lo mencionamos más arriba, el de des-biopolitizar la formación de los cuerpos prestigiados socialmente, para abrir espacio a aquellos que durante siglos han quedado fuera de escena por ser precisamente considerados "ob-scenos". Se trata de buscar un empoderamiento desde los márgenes, desde el cuerpo estigmatizado y herido, e incluso desde la obscenidad grotesca a la que da lugar también el ejercicio del biopoder.

Heredero de un arte performático "mexicano" como el del chicano Guillermo Gómez-Peña, cuyas performances interrogan los mitos del macho intercultural, o el de Rocío Boliver "La congelada de uva", basado en una combinación de prácticas porno-obscenas y profanaciones religiosas, Lechedevirgen es también creador de filiaciones a través de los talleres que imparte sobre cuerpo y performance. Receptor y emisor de prácticas artísticas que sacuden los binarismos del sistema sexo/género y los "grandes" relatos sobre raza y nación, este artista dedica su energía vital a cuestionar incansablemente los códigos convencionales de la masculinidad. Interrogar al género, al nacionalismo, a la clase y a la raza desde un cuerpo de subalterno estigmatizado, parece ser la única manera de hacer arte en la época contemporánea, quizás porque urge que emerja de las cenizas de un difunto cuerpo des-politizado, el nuevo sujeto queer post-identitario, una nueva ficción que aún no ha acabado de rascar ni de borrar la tinta del antiguo palimpsesto decimonónico en el que se escribieron parcialmente las reglas coercitivas del género. 


\section{Bibliografía}

Agamben, Giorgio. Homo sacer I. El poder soberano y la nuda vida. Trad. Antonio Gimeno. Valencia: Pre-Textos, 2010.

Anzaldúa, Gloria. Borderlands/ La Frontera. San Francisco: Aunt Lute Books, 1987.

Butler, Judith. El género en disputa. El feminismo y la subversión de la identidad. Barcelona: Paidós, 2007.

De Lauretis, Teresa. "Queer Theory: Lesbian and Gay Sexualities". Differences: a Journal of Feminist Cultural Studies, vol 3, núm. 2, 1991, pp. III-XVII.

Elnuevodia.com. "Habitar el cuerpo". El nuevo día, 20 de abril de 2010, en línea. Consultado el 27 de enero de 2018.

Foucault, Michel. "Des espaces autres". Architecture, Mouvement, Continuité, núm. 5, 1984, pp. 46-49.

Foucault, Michel. Histoire de la sexualité I - La volonté de savoir. Paris: Gallimard, 1976.

Goffman, Erving. Stigmate, les usages sociaux des handicaps. Paris: Les Editons de Minuit, 1975.

Gómez-Peña, Guillermo. "En defensa del arte del performance". Estudios avanzados de performance. Eds. Diana Taylor y Marcela Fuentes. México: Fondo de Cultura Económica, 2011, pp. 493-520.

Kosofsky Sedgwick, Eve. Epistemología del armario. Barcelona: Ediciones de la Tempestad, 1998.

Lanuza, Fernado R. y Raúl M. Carrasco, comps. Queer \& Cuir. Políticas de lo irreal. Querétaro: Fontamara, 2015.

Lechedevirgen Trimegisto. "Pensamiento Puñal". Tramoya. Cuaderno de teatro, núm. 120, 2014, pp. 13-20.

Lechedevirgen Trimegisto. "Pensamiento Puñal". Vimeo, 2013, en línea. Consultado el 28 de septiembre de 2015.

Maingueneau, Dominique. "Quelques implications d'une démarche d'analyse du discours littéraire". Contextes, núm. 1, 2006, en línea. Consultado el 26 de septiembre de 2015.

Maingueneau, Dominique. Le discours littéraire: Paratopie et scène d'énonciation. París: Armand Colin, 2004.

Moraga, Cherrie y Gloria Anzaldúa, eds. This Bridge Called My Back: Writings by Radical Women of Color. New York: Kitchen Table: Women of Color Press, 1981.

Muñoz, José Esteban. "Introducción a la teoría de la desidentificación". Estudios avanzados de performance. Eds. Diana Taylor y Marcela Fuentes. México: Fondo de Cultura Económica, 2011, pp. 555-603. 
Muñoz, José Esteban. Desidentification: Queers of Color and the Performance of Politics. Minneapolis / London: University of Minnesota Press, 1999.

Osornio, Felipe. "Felipe Osornio 'Lechedevirgen Trimegisto"' - Entrevista”. YouTube, 20 de octubre de 2014, en línea. Consultado el 20 de octubre de 2014.

Osornio, Felipe. "Entrevista en compañía de Felipe Osornio - Lechedevirgen Trimegisto - Realizada por Andrea". Vimeo, 9 de octubre de 2013, en línea. Consultado el 9 de octubre de 2013.

Osornio, Felipe. "Pensamiento puñal, crítica directa a las 'coreografías' sociales". La Jornada Jalisco, 20 de diciembre de 2013, en línea. Consultado el 28 de septiembre de 2015.

Preciado, Beatriz. "Entrevista con Beatriz Preciado: Posporno/Excitación disidente". Entrevista con Parole de Queer. Parole de Queer, 2014, en línea. Consultado del 25 de abril de 2016.

Prieto Stambaugh, Antonio. "El eros politizado del performance sexo-diverso en México". Conjunto. Revista de teatro latinoamericano, núm. 181, 2016, pp. 36-44.

Prieto Stambaugh, Antonio. "Corporalidades políticas: representación, frontera y sexualidad en el performance mexicano". Estudios avanzados de performance. Eds. Diana Taylor y Marcela Fuentes. México: Fondo de Cultura Económica, 2011, pp. 609-628.

Rubin, Gayle. "L'économie politique du sexe: transactions sur les femmes et systèmes de sexe/genre". Les cahiers du CEDREF, núm. 7, 1998, en línea. Consultado el 28 de septiembre de 2015.

Sandoval, Chela. "Nuevas ciencias. Feminismo cyborg y metodología de los oprimidos". Otras inapropiables. Feminismos desde las fronteras. Hooks, bell et al. Madrid: Traficantes de sueños, 2004, pp. 81-106.

Taylor, Diana y Marcela Fuentes, eds. Estudios avanzados de performance. México: Fondo de Cultura Económica, 2011.

ToutVaBienTV. "Lechedevirgen Trimegisto". YouTube, 15 de noviembre de 2013, en línea. Consultado el 28 de septiembre de 2015. 


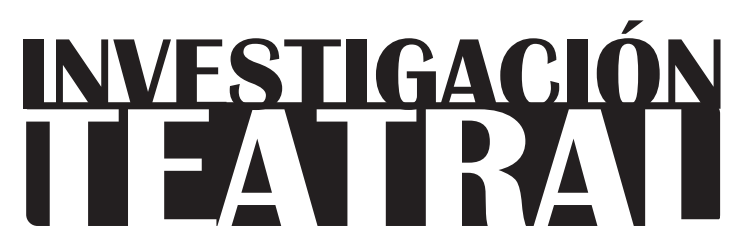

Revista de artes escénicas y performatividad

Vol. 9, Núm. 13

abril-septiembre 2018

Segunda época

ISSN impreso: 1665-8728

ISSN electrónico: 2594-0953

Universidad Veracruzana

\title{
Los talleres Drag King: Una metodología feminista de investigación encarnada
}

\author{
Alba Pons Rabasa*
}

\footnotetext{
* Universidad Autónoma Metropolitana Unidad Iztapalapa, México.

e-mail:alba_pons@cieg.unam.mx
}

Recibido: 30 de agosto de 2017

Aceptado: 09 de febrero de 2018 


\title{
Los talleres Drag King: Una metodología feminista de investigación encarnada
}

\section{Resumen}

En el marco de las críticas post-estructuralistas a la identidad, propongo el drag king como una metodología feminista de investigación encarnada que nos permite reflexionar corporalmente en torno a la identidad de género en tanto experiencia, pero también en tanto categoría teórica y política. A partir de dicho ejercicio performático y performativo se evidencian los desbordamientos y las tensiones existentes entre la propia experiencia y la representación de la misma. En un primer momento, ubicaré el origen de los talleres Drag King como herramienta de concienciación feminista, para después exponer lo que tal experiencia supone en una trayectoria vital específica a través de un breve relato autoetnográfico y, a partir de allí, problematizar la identidad de género.

Palabras clave: autoetnografía, investigación encarnada, identidad de género, performatividad, performance.

\section{Drag King Workshops: A Feminist Embodied Research Methodology}

\begin{abstract}
Based on post-structuralist critiques of identity, this paper argues that drag king performances may serve as a feminist embodied research methodology that allows us to think of gender identity as corporeal experience, but also as a theoretical and political category. These performative exercises make clear the overflows, tensions and gaps between first hand experiences and the way in which these might be represented and read by others. The origin of the Drag King workshops as a feminist awareness technique is briefly discussed. This is followed by a self-reflexive ethnography in which the author explains how drag king performances affected her own life history and how this led her to a problematization of gender identity.
\end{abstract}

Keywords: auto-ethnography, embodied research, gender identity, performativity, performance. 


\section{Los talleres Drag King: Una metodología feminista de investigación encarnada}

\section{Introducción}

E n este artículo problematizo el concepto de identidad de género a partir de la actuación drag king, considerándola como una metodología feminista de investigación encarnada. ${ }^{1}$ A través de un relato autoetnográfico, muestro la potencialidad de esta herramienta, tanto para reflexionar corporalmente en torno a nuestra identidad de género como para la producción de conocimiento teórico en nuestras investigaciones.

En el marco de las críticas post-estructuralistas a las políticas de la identidad, este ejercicio performático y performativo problematiza precisamente el concepto de identidad, evidenciando los desbordamientos y tensiones existentes entre la experiencia y la representación de la misma, a través de las categorías identitarias. Al mismo tiempo, permite realizar dicha problematización desde la propia corporalidad y subjetividad, teniendo por lo tanto un efecto transformador sobre nuestra práctica investigativa misma, (pues "el performance [...] es una práctica y una epistemología, una forma de comprender el mundo y un lente metodológico") (Taylor, Performance 31).

No es mi intención hacer aquí una genealogía del drag king en tanto que fenómeno contemporáneo, sino más bien ubicar el origen de los talleres como herramienta de concienciación feminista para, en un segundo momento, exponer lo que tal experiencia ha supuesto en una trayectoria vital específica a través de algunos trazos autoetnográficos. A

${ }^{1}$ El término drag se utiliza en lengua inglesa para referirse a un tipo de actuación travesti. Drag queen es el hombre travestido de mujer, mientras que drag king es la mujer travestida de hombre [n. del ed]. 
partir de ello propondré una problematización de la identidad de género como concepto analítico y político, para finalmente convocar a la utilización de esta técnica en la investigación encarnada.

Esbozar una autoetnografía posibilita reflexiones corporales y experienciales que complejizan los planteamientos analíticos en torno al tema que queremos trabajar. Lo que en este caso, concretamente, constituye un claro intento por desestabilizar ya no solamente el género y la heteronormatividad, sino también algunos principios objetivistas que suelen subyacer a este tipo de trabajos, deviniendo obstáculos para la creación de conocimiento situado y encarnado. Siguiendo a Caroline Ellis, "esta aproximación [la autoetnografía] desafía las formas canónicas de hacer investigación y de representar a los otros (Spry 2001), a la vez que considera a la investigación como un acto político, socialmente justo y consciente (Adams y Holman Jones 2008)" (“Autoetnografía: un panorama” 50).

Si de acuerdo con la autora citada (2000), podemos ubicar dentro de la autoetnografía diferentes subtipos, el presente artículo pretende mostrar un uso de esta técnica como parte de la etnografía reflexiva característica de la investigación feminista (Ellis, "Autoetnography" 740). Se trata, en efecto, de producir ciertos trazos autoetnográficos ${ }^{2}$ desde los cuales profundizar en el análisis de algunos aspectos relativos a la cultura de género, en pos de generar un distinto encuentro o diálogo entre nuestros trabajos de investigación feminista que nos permita complejizar y encarnar el pensamiento que producimos.

\section{Orígenes de los talleres Drag King}

Los talleres Drag King ${ }^{3}$ nacieron de manos de la artista y activista Diane Torr en la ciudad de Nueva York hacia 1990. Casi por casualidad, esta feminista escocesa, performancera y educadora, experimentó en carne propia lo que implica una transformación

${ }^{2}$ Hablo de trazos y apuntes autoetnográficos porque no presento en este artículo una autoetnografía completa; más bien realizo un ejercicio narrativo que recupera parte de una experiencia vivida para pensar y analizar algunos aspectos útiles a mi trabajo de investigación y a mi experiencia personal. Se trata de un esfuerzo por relatar la experiencia drag king como epifanía en mi trayectoria vital, considerándola al mismo tiempo como una técnica que me ha permitido encarnar - es decir, pensar y hacer inteligible desde la experiencia corporal-, ciertos análisis sobre el género, el cuerpo y la sexualidad. Estos análisis, a su vez, resultan imprescindibles para mi trabajo de investigación, en tanto que cuestionan el lugar desde el cual producir conocimiento sobre los temas mencionados, así como las formas de hacerlo y las representaciones que se generan en la producción misma de conocimiento.

${ }^{3}$ Se escribe Drag King con mayúsculas cuando se hace referencia a los talleres de Diane Torr [n. del ed.]. 
como la del drag en el espacio público. Los efectos emocionales, corporales y subjetivos de dicha experiencia, le animaron a investigar e impartir los talleres en torno a este tipo de performance.

A través de la enseñanza de diversas técnicas y usando cierta metodología teatral para representar masculinidades, Torr pretendía que sus talleristas pasaran ${ }^{4}$ como hombres y pudieran "experimentar la autoridad del hombre, su territorio y sus derechos" (Halberstam, Masculinidad Femenina 280).

La descripción es de un libro de 2008 que dedica un capítulo completo al fenómeno, cuyo autor/a queer, Jack/Judith Halberstam, propone una taxonomía de los diferentes tipos de drag king que pueden hallarse en el espectáculo. Según él/ella, los talleres de Torr quedarían circunscritos a la categoría "mimetismo de hombres", pues a diferencia de otros tipos de performances, en ellos se sigue vinculando y asociando la masculinidad a los varones, reificando así tal articulación y reproduciéndola sin proponer otras "reconstrucciones de la masculinidad".

Diane Torr y su metodología constituyen un referente ineludible en el campo de los talleres Drag King. En el libro que publicó junto al crítico de arte Stephen Bottoms, Torr hace un recorrido por su historia en el mundo de la performance feminista - al que llegó con una acción que realizó al lado de sus compañeras de trabajo del club de gogo's-, y a través de sus diferentes formaciones artísticas (Release dance, Contact Improvisation y otras danzas); camino que recorrió con especial interés en indagar a profundidad acerca del cuerpo y las construcciones sociales de género. En un contexto de intensos debates dentro del feminismo sobre las expresiones de la sexualidad de las mujeres, la pornografía, el trabajo sexual y la violencia, sus performances adquirieron una fuerte carga provocadora y cuestionadora del esencialismo y de los roles estereotipados de género. ${ }^{6}$

${ }^{4}$ Se utiliza aquí el verbo "pasar" y el sustantivo "pasabilidad" para indicar la capacidad de ser reconocida/o con el género que deseas ser interpretada/o, (cuando no se corresponde este último con tu género registral $o$ asignado al nacer).

5 Tanto Torr como Halberstam disponen de una genealogía propia del término y la práctica del drag king. Paul B. Preciado reconoce en Torr a la creadora misma del término (2004), pero Torr lo atribuye a Johnny Sciencie (Torr y Bottoms 2010, 99). Más allá de la cuestión de la autoría, lo cierto es que Torr en 1990 dio su primer taller Drag King, mientras que Del La Grace Volcano afirma, en The Drag King Book (1999) copublicado con Halberstam, que en 1985 asistió por primera vez a un "acto drag king". Esta última publicación se puede considerar como pionera en el estudio del tema, a partir de fotografías de los primeros rastros de una cultura drag king emergente ubicada en San Francisco, Nueva York y Londres (Volcano y Halberstam 1999, 10). Tales trabajos constituyen sin duda un archivo histórico fundamental.

${ }^{6}$ En aquellos momentos, el conflicto entre abolicionistas y pro-sex en Estados Unidos era muy intenso y las performances de gogo de Torr pretendían cuestionar la relación que las primeras veían entre sexualidad, erotismo y dominación masculina. Ver Torr y Bottoms (2010). 
En abril de 1989, cuando Diane Torr ya era conocida por algunos de los personajes masculinos de sus performances, fue convocada por Annie Sprinkle (feminista pro-sex estadounidense) para modelar las fotografías del "antes" y el "después" que ilustrarían una entrevista realizada a Johnny Sciencie, fundador de uno de los primeros grupos neoyorquinos de transexuales y cross dressers female-to-male, "F2M Fraternity". El mismo día en que se inauguraba la Whitney Museum's Biennial Exhibition, se llevó a cabo la sesión de fotos, al finalizar la cual la escultora Sonja Oudendijk - la amiga alemana que acompañaba a Torr-, se precipitó a partir hacia el evento y presionó a su acompañante para salir tal como estaba caracterizada. Nadie reconoció a Torr al llegar, lo que le permitió observar el evento desde el rol del voyeur y experimentar cómo la identidad es relativa y relacional (Torr, Sex, Drag 198). Notó que al pasar como hombre, cambiaba automáticamente el lugar que se le asignaba socialmente y que las interacciones eran totalmente distintas. Todo ello la motivó a proponerle a Johnny Sciencie la planeación de un taller, en el que éste pudiera transmitir las técnicas de transformación corporal que conocía, mientras la propia Torr proponía herramientas para la creación física de personajes masculinos (94-100). Así fue cómo comenzó a explorar e investigar mediante talleres desde 1990, ${ }^{7}$ abriéndosele "la posibilidad de crear, a través del aprendizaje teatral de la masculinidad, un nuevo territorio para la experiencia del cuerpo".

\section{Apuntes para una autoetnografía drag I. Fragmentos corpobiográficos.}

El drag king me ha acompañado de uno a otro lado del océano, en experiencias que han ocurrido en contextos tan diversos como cafés-teatros de Quito (algunos muy precarios y otros glamourosos), los centros sociales okupados de una Barcelona en transformación o el activismo transfeminista autónomo radical. También he impartido talleres en centros de salud de la administración pública del Estado español, así como en escuelas, jornadas académicas de la Universidad de México y hasta en un centro cultural bonaerense. Mi presente no tiene nada que ver con mi ayer y el drag king tiene un papel fundamental en este recorrido transformador.

7 Tal como relata en su libro, antes de ofrecer estos talleres con Johnny Science, los personajes masculinos de Torr evidenciaban su carácter de artificio, pues ella todavía no conocía las técnicas que permitían que el personaje "pasara" como hombre. Eso fue lo que le aportó la experiencia transgenérica de Johnny Science (Torr y Bootoms, Sex, Drag 98).

${ }^{8}$ Como relata Beatriz Preciado (2004) a partir de lo que Diane Torr expone en la película de Gabriel Baur, Venus Boyz (2002). 
Es necesario advertir que una mirada retrospectiva implica recrear el pasado atendiendo al carácter performativo de la memoria. El drag, como una suerte de epifanía en mi historia de vida, será aquí revisitado para proponer ciertas reflexiones analíticas encarnadas a través de un análisis autoetnográfico, que nos permitan por un lado cuestionar el concepto de identidad, y por el otro, las formas en que hacemos investigación. Digo "autoetnográfico" porque - siguiendo a Ellis (2015) - además de tratarse de un relato con carácter autobiográfico, pretende utilizar la experiencia personal para ilustrar ciertas facetas de la experiencia cultural, poniendo en juego para ello algunas herramientas metodológicas y literatura científica.

Fui una "niña-niña". No recuerdo haber tenido conflictos con ello ni mi madre me ha relatado alguno. De hecho, creo que era la "niña-niña" más feliz del mundo, jugando con muñecas, a mamás y a papás, a hacer de cantante, bailarina y demás ejercicios de feminidad. Desde los cuatro hasta los dieciocho años recibí clases de ballet clásico: feminidad y disciplina. Aunque nunca me había quejado, el día en que a los quince años me pusieron una báscula enfrente no quería pesarme (había llegado el momento de añadir la disciplina alimentaria a la disciplina corporal del ballet). Comencé a odiar a mi profesora, asumí que no me gustaba mi cuerpo y me resistí a regular mi alimentación.

Hice también patinaje y teatro. En el baloncesto de la escuela duré poco. En las clases de gimnasia, mis compañeros se reían de mi forma de correr. La adolescencia fue una etapa que me pareció terrible y llegó antes de lo esperado: la menstruación y esas dos nuevas desconocidas que entonces me abrían paso en la vida, mis tetas. Me resistía llorando cada noche sin motivo alguno. Era solamente tristeza. "Llora hija, sácalo..." Y ya.

Poco a poco esas lágrimas nocturnas dejaron de caer y mis manos comenzaron a descubrir mi cuerpo. Al poco tiempo, también otras manos y cuerpos ajenos se mezclaban con mi piel en mis primeros rituales de "amor" (sexo de principiantes, poco placer y mucha curiosidad). Sexo heterosexual sin cuestionamientos. Ya era una mujer heterosexual.

Tuve que conocer lo trans* y el feminismo para interrogarme sobre mi ser mujer y mi ser heterosexual, sobre mi identidad y mi deseo. A partir de ahí, nunca más me he alejado de estos lugares; lo trans* y el feminismo son actualmente la base de mis reflexiones y transformaciones: de mis pensamientos acerca de la heterosexualidad obligatoria, el binarismo de género, el encuentro erótico entre mujeres, el sistema sexo-género, la performatividad, la performance y muchos otros conceptos y prácticas que me han ayudado a leer la realidad, entenderla e ir mutando.

No fue sino hasta 2007 - cuando tomé un taller Drag King- que me pasaron realmente por el cuerpo ciertos cuestionamientos que llevaba años haciéndome de manera abstracta. Entonces entendí por fin ciertas teorías que había leído y me sabía de memoria, sin haberlas comprendido a profundidad hasta aquel momento. Yo vivía por entonces en 
Quito con mi compañera de cama y de activismo, y para una fanática del teatro social, feminista y obsesiva de lo trans", el título "Teatralidades del género" — como se llamaba el taller - resultaba suculento. Mi compañera, por su parte, ya hacía drag king en un humilde y glamouroso café-teatro, El Dionisios, donde yo recientemente había experimentado con el drag queen.

En "Teatralidades del género" conocí a la artista Susana Cook. ${ }^{9}$ Ella fue directa con su pregunta: “¿Han traído su ropa?” La noche anterior había estado probándome medio closet de mi compañera con su supuesta ropa "de hombre" y no encontré nada. En la tienda de la Casa del Árbol hallé finalmente un traje de señor, que fue lo que me puse aquel primer día del taller. Un traje de señor para performar una masculinidad blanca, burguesa y heterosexual.

Susana nos enseñó las técnicas para travestirnos, los trucos para perfomar una masculinidad paródica que "pasara" como tal. Aprendí a hacer la barba, el "paquete", a vendarme los pechos, y después el caminar, respirar, fumar, bailar... hablar. En ningún momento, sin embargo, conseguí entrar del todo en ese alter ego; ${ }^{10}$ me sobraban partes de mi cuerpo y me faltaban accesorios y actitud. "Se me chorreaba la feminidad por todos lados" y eso me enfureció, me entristeció y me obligó a preguntarme muchas cosas que antes no me había preguntado.

Veía a mis compañeras reírse, divertirse, fluir. Habían conseguido performar masculinidad, reírse de ella, parodiarla y, por tanto, pensar en cómo se habían construido como "mujeres copia". Yo no.

Esa noche tenía muy claro que al día siguiente no iba a volver al taller. Mi compañera me dijo: "Alba, no lo fuerces, busca una masculinidad más afín contigo, con tu cuerpo; aunque no te guste, aprovecha aquello de tu cuerpo que también pueda ser parte de esa masculinidad, no fuerces a un ejecutivo. No solo estamos representando masculinidad, sino que son personajes cruzados por otras características, busca el tuyo".

Era cierto: no hay hombres a secas, no existen. Existen hombres blancos, heterosexuales, de clase alta, ejecutivos de multinacionales. Existen raperos de barrio, gitanos y chavos que limpian los cristales de los coches. Maricas. "Fresas" diseñadores de ropa que viven en los barrios bohemios de capitales. Solo tenía que encontrar al hombre de mi vida. Volví al closet de mi compañera y me solté el cabello (por entonces tenía rastas que me llegaban por

9 Artista de performance de origen argentino, radicada en la ciudad de Nueva York. Cook se reconoce como lesbiana feminista, radical y comprometida. Hace monólogos políticos que satirizan a la sociedad estadounidense y su conservadurismo. Para mayor información ver el portal: www.susanacook.com

${ }^{10}$ Diane Torr (2010) utiliza el concepto de alter ego para referirse a los personajes que se ponen en juego en los talleres. 
encima del trasero). ¿Dónde se ha visto a un ejecutivo de traje y corbata con esas rastas? Tomé unos jeans anchísimos, una playera que me iba grande, un chaleco de plumas y un pañuelo rojo. Me lo puse y caminé... femeninamente..., como siempre. Mi compañera me enseñó a ocupar el espacio, andar con las piernas abiertas, prestarle atención a mi nuevo centro: el "paquete". Tuve que repetirlo y repetirlo, ensayar.

Ese fue mi alter ego al día siguiente en el taller y fluyó tanto que la fotógrafa, que llegó cuando ya estábamos vestidos, se preguntaba qué hacía ese tipo en un taller que estaba dirigido a mujeres. Susana rió y yo me sonrojé. ¿Ya "pasaba" por hombre?, ¿qué me había pasado? Me miré al espejo, vi mi barba, mis facciones marcadas, una mirada distinta y más directa, ninguna sonrisa complaciente. ¡Y sí!, parecía un hombre, un chico y, además, un chico malo. Sorpresa, extrañeza, ilusión, un poco de desagrado, duda, hasta miedo... muchas cosas. Cierto sentido de autenticidad, como relatan las alumnas de Torr (196). Sentido de autenticidad que me descolocaba y que ponía en cuestión, a la vez, el sentido de autenticidad de mi performance más cotidiana. Ensayamos durante horas nuestros bailes, así como diferentes situaciones clásicas donde la masculinidad hegemónica se explaya: peleas callejeras, borracheras, partidos de futbol, acoso a las mujeres de la calle...

No me gustaba lo que hacíamos pero sí me gustaba sentirme en ese papel, moviéndome así, mirando así, retando, ocupando todo el espacio, hasta luchando por él. Era diferente y me trataban diferente. En verdad podía ocupar esa posición, aun cuando nunca lo hubiera imaginado porque eso ponía en tela de juicio la unicidad de mi propia identidad: "Si la identidad masculina y femenina pueden convivir en un mismo cuerpo, el concepto de identidad singular, no se diga el de género singular, es puesto en cuestión". ${ }^{11}(197)$

Al tercer día reflexionamos todas juntas sobre qué nos había pasado en las exploraciones. Algunas se habían sentido liberadas, otras ya no volvieron al taller, otras más querían quedarse con su personaje masculino... Pero todas y cada una de nosotras habíamos vivido algo en común: el cuestionamiento de esa performance de género que hacemos día a día, creyendo que fluye y es natural. ¿Performance performativa? Performance que materializa nuestros cuerpos de mujeres, produciéndonos como sujetos generizados.

¿Por qué cuando me siento cruzo las piernas?, ¿por qué muevo las caderas cuando camino?, ¿por qué sonrío a todo desconocido que me mira o me dice algo, aunque sea desagradable?, ¿por qué ocupo el mínimo espacio posible?, ¿por qué miro al suelo?, ¿por qué

11 "If mail and female identities can coexist within the same body, then the concept of singular identity, let alone singular gender, is thrown into question". 
fumo delicada y discretamente?, ¿por qué respiro de a poquito y silenciosamente?, ¿por qué hablo bajito? En mi chico con rastas nadie me miraba, prácticamente me regalaban el espacio para que yo lo ocupara. Algunas mujeres se apartaban medio asustadas, aunque nunca supe si era porque parecía un hombre o por mi pinta de malo.

A mi regreso a Barcelona ya había dos grupos en el Estado español que daban este tipo de talleres: las Medeak ${ }^{12}$ y las O.R.G.I.A. ${ }^{13}$ Me uní a los de las Medeak y seguí compartiendo mis reflexiones corporales con compañeras feministas. Los talleres consistían en compartir los trucos para draguearnos, simular algunas situaciones clásicas y salir a la calle. Pero me faltaba algo, trabajar más con el cuerpo, destrabarlo, desinhibirlo, desmecanizarlo para soltar esa feminidad tan instalada.

Junto con dos aliadas, decidí empezar a investigar y trabajar para poder impartir nuestros propios talleres, convocando en primer lugar a nuestras compañeras feministas. Propusimos, como novedad, centrarnos no en la transformación con las diferentes técnicas sino en el cambio de actitud, posición, eje, movimiento, es decir, en el cuerpo y la reflexión colectiva. Utilizamos técnicas del teatro social para trabajar una primera parte del taller, en la que poníamos en juego nuestros cuerpos "de mujer". Los pusimos a interactuar y luego intentamos des-mecanizarlos mediante ejercicios que convocaban a las risas, cooperación, extravagancias, ridiculeces y demás. Jugábamos con nuestras propias concepciones estereotipadas a través de crear "fotografías" de lo que se nos venía a la mente cuando decíamos palabras como "travesti", "feminidad", "masculinidad", "odio", "amor" y otros términos vinculados directa o indirectamente con las definiciones de los ideales regulatorios de género. Nos confrontamos con imaginarios que a final de cuentas nos constituyen. Después, la gente estuvo dispuesta a dejarse llevar.

Una parte fundamental de estos talleres consiste en la trasformación corporal mediante la ocultación del pecho, la creación y colocación del "paquete" en la entrepierna, el diseño de la barba o bigote, la colocación de vello corporal donde cada king desee y el maquillaje para ensombrecer algunos rasgos faciales.

Aunque la venda elástica es uno de los recursos más fáciles y económicos para aplanar y esconder el pecho, no es el único. Existen fajas deportivas, originalmente dise-

12 Colectivo transfeminista de Donosti (País Vasco) que aprendieron a dar talleres King de la mano de Beatriz Preciado en Barcelona, cuando organizó en 2005 en el MACBA el taller de Tecnologías del Género (http:// www.macba.cat/es/tecnologias-del-genero-micropoliticas-postidentitarias) .

13 Colectivo artístico feminista de Valencia que en 2005 impartió su primer Taller Drag King en contextos académicos/artísticos. Ver referencia en bibliografía.

${ }^{14}$ Mediante la técnica del “Teatro Imagen”, que forma parte del arsenal de metodologías utilizado en el Teatro social o Teatro del oprimido, propuesto por Augusto Boal. 


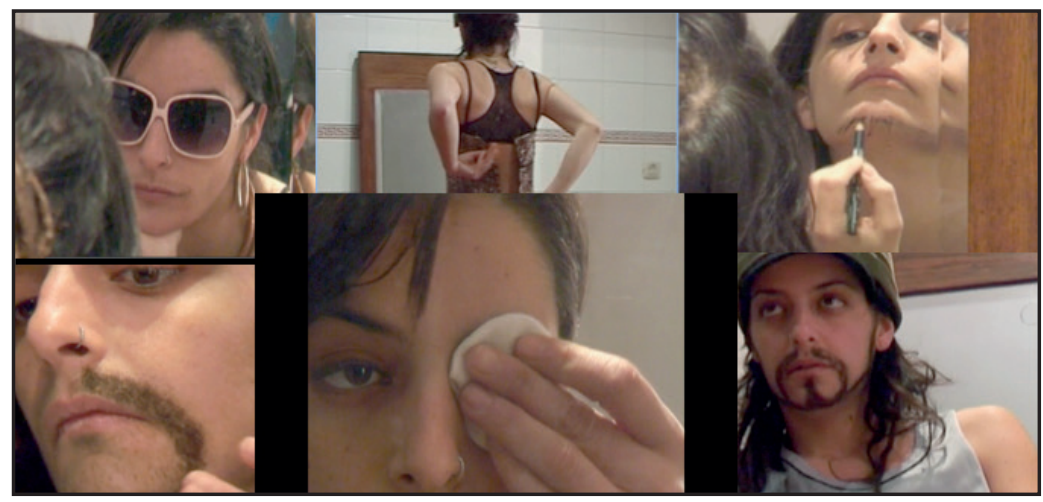

Talleres Drag King. Ciudad de México, México, 2015. Fotografía de Amalia Ospina Palacios.

ñadas para la cintura, que no obstante pueden usarse cómodamente con este fin. Hay también bynders ${ }^{15}$ caseros o comerciales que algunos chicos transgénero suelen utilizar. Por otra parte, hay cuerpos que no necesitan ocultar nada u otros que, por el contrario, tienen que utilizar relleno de espuma de poliuretano en la barriga para disimular unos pechos demasiado grandes, que definitivamente no se puedan aplanar con ninguna de las técnicas mencionadas.

El cambio perceptual provocado por la venda o la faja en el pecho es muy importante. Sentir el busto presionado e inexistente transforma la postura corporal y la sensación, pareciera que el pecho constituye un foco que con su ocultación cambia de lugar y nos obliga a curvar la espalda cerrando los hombros (produciendo un efecto subjetivo que difícilmente se puede describir). Por otro lado, el aprisionamiento de las vendas y la consecuente dificultad para respirar, nos sirve para mantenernos en este otro centro corporal y en nuestro nuevo alter ego. A algunas personas nos gusta esta sensación y otras la detestan, pero lo que está claro es que, más allá de que estéticamente se consiga la ocultación absoluta del pecho, tiene un efecto corporal específico que constituye un marcador de género determinante.

El momento de la fabricación del "paquete" es el que más hilaridad genera y no creo que se trate solo de casualidad, atendiendo a que la risa es un gran indicador de desorden social. En mayor o menor medida, las carcajadas que se desatan durante esta tarea están vinculadas a lo inapropiable de estar fabricándonos un pene para nuestro drag, de estar plagiando el falo (tan cargado simbólicamente y sobrecodificado en términos de género).

${ }^{15}$ Se trata de camisetas interiores elásticas muy fuertes que aplanan el pecho, similares a los brasiers deportivos. 
La técnica al uso es de lo más sencilla: un condón relleno de algodón al que cada tallerista da la forma y tamaño que desee. Se recomienda que sea grande y con una base más ancha - a modo de testículos - que nos permita sentirlo entre las piernas. Ha habido mujeres que no se han atrevido a hacerse paquetes grandes y otras que han verbalizado lo sumamente placentero que les resulta sentir "el roce constante de eso grande entre las piernas". Sin duda, existe mucha diversidad en la manera de relacionarnos con ese "extraño" que va a tomar protagonismo en nuestra performance.

De lo que estoy convencida es de que al sentirlo ahí como un accesorio nuevo y contundente, en constante roce con nuestra zona genital y con la cara interior de los muslos -y sumado a la sensación que produce la ocultación del pecho-, el centro corporal baja. El "paquete" se convierte en nuestro nuevo eje rector y esto modifica tanto la autopercepción como la percepción del entorno. Es como mirar el mundo desde otro lugar, y de hecho se mira al mundo desde otro lugar.

El rostro, que juega un papel primordial en la presentación social y en la identidad, constituye una parte muy importante en la transformación drag. El trabajo con los rasgos faciales es el que exige más detalles y comienza por la visualización. Hay que diseñar el vello facial en función de algún personaje masculino previamente definido, a partir de la observación de diferentes hombres. Dependiendo de lo que queramos, utilizamos trocitos muy finos y pequeños de nuestro propio cabello, o bien algún rímel con el que resaltamos el vello que la mayoría de las mujeres ya tenemos en la cara (cuando no nos depilamos).

Antes de colocar el vello, con un lápiz negro de maquillaje dibujamos sobra la piel nuestra barba, bigote, cejas y/o las patillas. Se marca su recorrido y luego se le difumina con los dedos, para enseguida revestirlo de pegamento facial o gel de pelo y, ahora sí, rellenar con los trocitos de cabello que habíamos cortado previamente. Si bien este ritual se puede hacer de forma individual, un trabajo colaborativo a la hora de hacer las barbas, patillas y bigotes puede constituir un momento perfecto para comenzar a preguntarnos colectivamente por nuestros alter egos: ¿de dónde es este hombre?, ¿cuántos años tiene?, ¿cómo se llama?

La ropa y accesorios vienen después, en un momento en el que el taller rebosa ya de masculinidades plurales en incipiente interacción: gritos, risas, choques de manos, de hombros, mientras se escoge la mejor ropa para cada nuevo personaje. Normalmente, la ropa y accesorios no constituyen elementos centrales para la performance de la masculinidad, pero dotan a cada king de un estilo particular y lo diferencian del resto.

El momento de draguearnos es especial cuando se realiza como ritual colectivo, genera muchas reflexiones y emociones compartidas que posibilitan su incorporación al carácter de cada personaje en construcción. Ninguno de los personajes está aún del todo afianzado, 


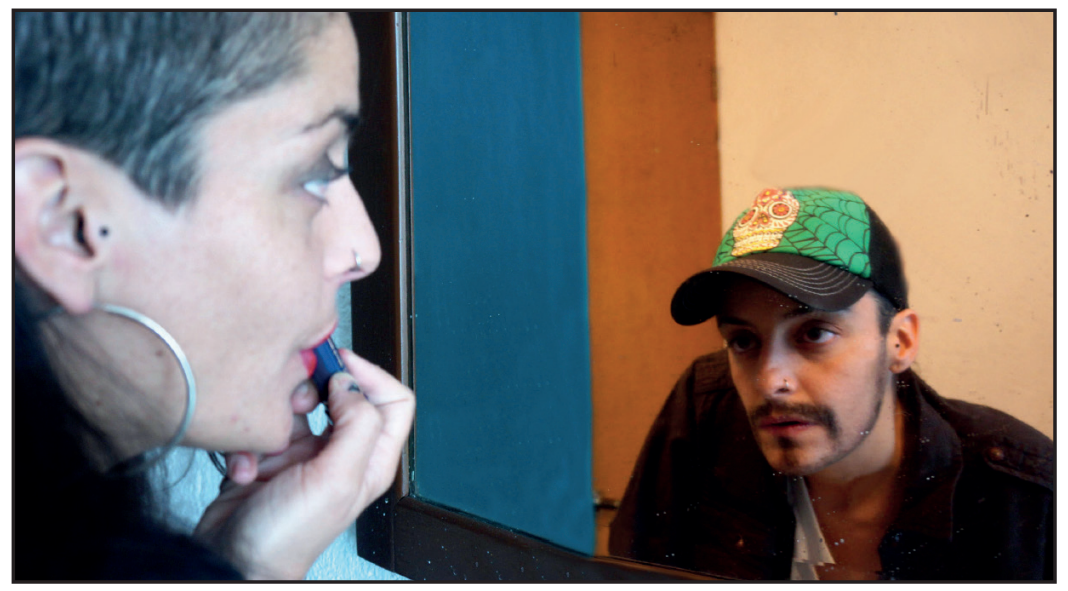

Talleres Drag King. Barcelona, España, 2010. Fotografía de María Berzosa Suescun.

será necesario realizar sucesivos ejercicios para trabajar corporalidades "machas" y lograr la transición corporal hacia los personajes. Se trabaja con el rostro, las piernas, la espalda, los hombros, la cintura, el "paquete", las rodillas y los pies...

En vez de bajar los ojos, se experimenta ahora con una mirada recta, directa, observadora, contundente y por lo general escurridiza (a menos que se quiera retar al otro). Se busca una mirada capaz de ocupar el espacio tal como debe hacerlo el resto del cuerpo. La seriedad que evita la sonrisa complaciente define perfectamente a la masculinidad en un rostro; una seriedad que afila nuestras facciones, las endurece y —-sumada al tipo de mirada descrito- desprende una actitud ruda que se relaciona socialmente con lo masculino. Cuando la vemos en el espejo, esta cualidad nos invita a entenderla como una capa más de la que nos podemos apropiar y con la que podemos jugar.

Los hombros no están rectos ni tensos, más bien caen un poco hacia adelante sobre una espalda que ya no necesita estar erguida como en el ballet clásico. "Relájense chicos, dejen caer sus hombros y su espalda, el centro ha cambiado de lugar, ahora está en el 'paquete". De ahí saldrá la energía que nos moverá ahora por el mundo.

Las caderas dejan de bailar al caminar, lo que se logra mediante ejercicios colectivos de imitación. Las piernas, en vez de mantenerse pegadas como si resguardaran ciertas partes íntimas, permanecen ahora abiertas para darle lugar al "paquete" y para hacerse espacio en el metro, camión o banco del parque. La voz es lo más difícil de trabajar y en los talleres para principiantes no suele lograrse una modulación precisa, pero todo es constantemente una prueba y error. Ayuda por lo general intentar una voz más grave, con mayor volumen y menos titubeos, muy usada. Para alterarla, se realizan ejercicios de exageración, aunque lo difícil es fijar los hallazgos. 
INVESTIGACIÓNTEATRAL

Revista de artes escénicas y performatividad

Vol. 9, Núm. 13

abril-septiembre 2018
Los talleres Drag King: Una metodología

feminista de investigación encarnada

Alba Pons Rabasa

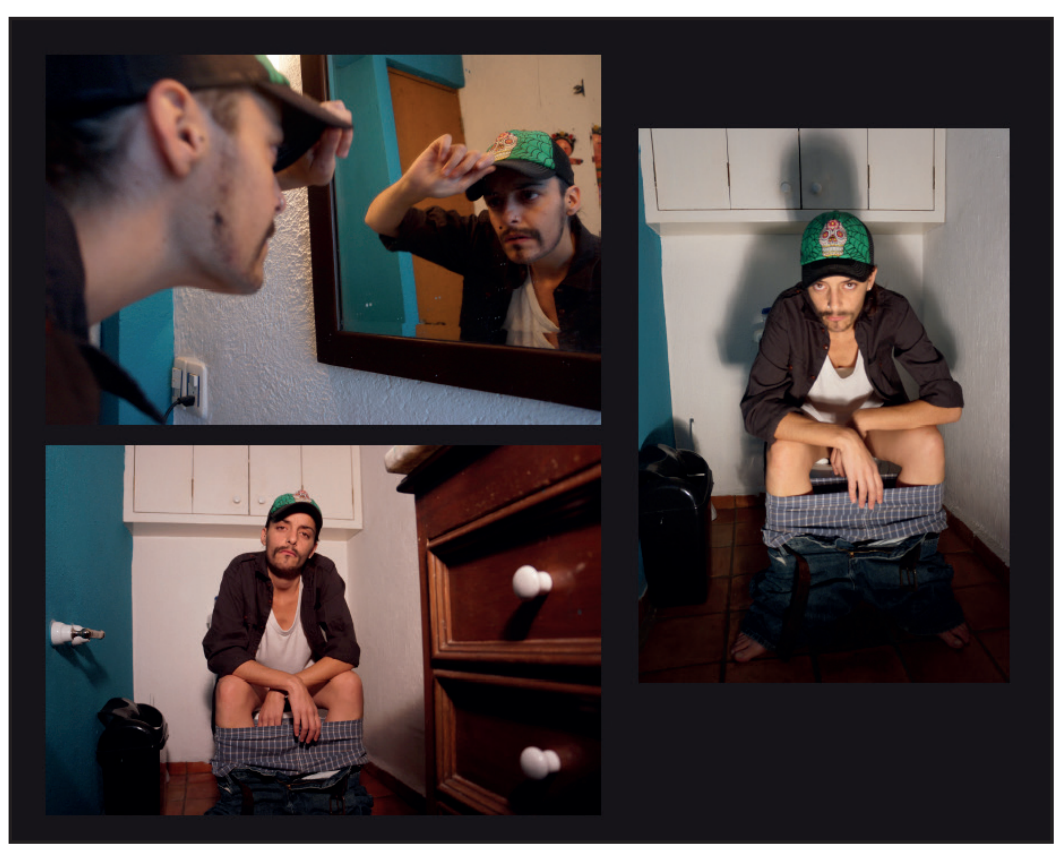

Talleres Drag King. Ciudad de México, México, 2015. Fotografía de Amalia Ospina Palacios.

Todos estos cambios corporales son practicados y repetidos, reafirmados y consolidados a través de ejercicios que ya se habían hecho en la primera parte del taller (cuando todavía no nos habíamos dragueado); esta vez con la intención de construir un alter ego mediante el ejercicio de "la silla caliente". ${ }^{16}$ Después de esto, el nuevo king ya tiene nombre, edad, familia, ocupación, barrio, aficiones.

Después del trabajo con la corporalidad se pasa a los sociodramas (sketches en los que simulamos determinadas situaciones sociales desde nuestra nueva posición). Bailamos, peleamos, bebemos, fumamos, piropeamos, conversamos, etcétera. Es el paso previo antes de sacar a nuestros kings a pasear. Las concepciones que tenemos sobre la masculinidad hegemónica, característica de la cultura de género en la que estamos insertas, florecen desde la sátira, la hipérbole y la parodia: desplegamos la retórica del género.

Es en la calle donde cada nuevo king puede experimentar de verdad la interacción social, ya sea directa o indirectamente, pero con la incertidumbre que implica enfrentarse a lo real. La salida al espacio público genera miedo, pues osamos ocupar una posición que supuestamente no es para nosotras, un lugar supuestamente inapropiable. El miedo a ser

16 Ejercicio de teatro social que se usa para la construcción de personajes. Consiste en colocar una silla al centro del círculo de participantes, donde se sienta uno de ellos mientras el resto le pregunta las características de su personaje. El interrogado debe responder lo más rápida y espontáneamente que pueda. 
descubiertas en tal ultraje suele estar presente durante los primeros momentos de nuestra performance, hasta que poco a poco nos vamos relajando y percatando de que se trata de un lugar perfectamente apropiable. Esa misma apropiación puede incluso transformarse o teñirse de tonos diferentes a los habituales.

Los bares son espacios idóneos para poner a prueba a nuestros alter egos. Al notar alguna señal que meta duda sobre la "veracidad" de sus nuevos compañeros de cantina, los jóvenes comunes con quienes interactuamos suelen desubicarse profundamente. Podría contar miles las anécdotas callejeras llenas de risas y reacciones de lo más variopintas por parte de los hombres "de verdad". Sorpresa, confusión, desorden... son algunas de las emociones que emergen en el instante mismo en que, una identidad que la excede, impacta contra la cultura dominante de género. Reacciones que se explican porque esta extraña identidad, en vez de citar a la cultura de género para reproducirla tal cual, la refleja para parodiarla y poner en evidencia su condición ideal o fantasmagórica (ver Butler, El Género y Cuerpos que importan).

Las caras de sorpresa, sin embargo, se presentan en menor cantidad que las caras de indiferencia, alterando nuestros propios esquemas. Nos desequilibra tener la capacidad de pasar inadvertidos, no ser observados fijamente en la calle, cuando estamos habituadas a ser el centro de atención en los espacios públicos (que parecieran estar dispuestos como pasarelas para el discurrir de nuestra feminidad). Pasar de ser espectáculo a espectador es uno de los grandes cambios que el King nos permite experimentar, asociado a la recién descubierta posición del "hombre": aquel que observa y objetualiza desde una posición de dominio.

Durante la reflexión colectiva que tiene lugar al final del taller, se comparten todas las emociones generadas tanto por la trasformación física como por el cambio de posición social. Muchas mujeres se sienten liberadas y asocian la percepción de poder que supone la transformación, directamente con la libertad. Al respecto, hay que mencionar que las talleristas que piden ropa y accesorios prestados a sus parejas varones para los ejercicios, frecuentemente reciben de ellos burlas y/o desprecio; en respuesta a lo cual -y después de haber sentido en el trabajo dicha "liberación" - muchas veces deciden volver a casa como kings. También hay mujeres que sienten rechazo en esta posición de poder, algo que puede estar mezclado con el morbo o incluso con una sensación de auto-empoderamiento erótico. Cada taller Drag King, en suma, genera reacciones emocionales sumamente plurales.

En el caso de las lesbianas masculinas que participan, suelen terminar performando masculinidades diferentes - y curiosamente más afeminadas - a las que desempeñan cotidianamente. Trabajadoras sociales y enfermeras se abandonan a la tentación de parodiar a sus pacientes hombres, sanando mediante este ritual la sobrecarga de expectativas y presiones sociales inherente al rol social que implica su trabajo. 
Paradójicamente, en todos los talleres hemos terminado reflexionando sobre la feminidad. Al cotejar nuestras vidas cotidianas con lo vivido en las experimentaciones drag, conseguimos analizar desde un lugar de conciencia diferente nuestras situaciones diarias. Se vuelve entonces posible comenzar a reflexionar sobre cuestiones y sutilezas que, al estar confundidas con la normalidad, anteriormente resultaban invisibles o incuestionables. ¿Por qué nunca me quejo cuando en el metro voy sentada entre dos hombres con las piernas totalmente abiertas, mientras yo apenas y quepo en el asiento? ¿Por qué me vuelvo el centro de atención al entrar en un bar o en un autobús? ¿Por qué sonrío siempre a quien simplemente me pregunta la hora o incluso a quien me echa un piropo que no me gusta? ¿Por qué me siento mal cuando reclamo mi espacio o mi libertad de no sonreír? ¿Por qué me siento con las piernas cruzadas y ocupando el mínimo espacio posible al llegar al cine, incluso si no hay mucha concurrencia? ¿Por qué intento estornudar o reír de la manera más silenciosa posible, cuando supuestamente se trata de gestos instintivos?

\section{Apuntes para una autoetnografía drag II. Reflexiones analíticas encarnadas}

La técnica drag king desestabiliza las fronteras de los sujetos que hemos crecido como "niñas-niñas" o como "niñas-menos-niñas", los límites que restringen nuestros movimientos corporales, gestos e incluso nuestras reacciones más instintivas. La nueva percepción de posibilidades corporales y subjetivas que ella convoca, evidencia la cualidad "múltiple y mutable del self" (Torr y Bottoms, Sex, Drag 197). Las utilidades cotidianas son muchas, por ejemplo, mejores recursos para defendernos de las microagresiones o agresiones machistas a las que estamos sometidas continuamente en los espacios sociales predominantemente masculinos. Una calle de noche puede recorrerse de otra manera: podemos pasar inadvertidas, caminando abiertamente, ocupando el espacio, con los hombros caídos y la espalda ligeramente encorvada.

Las múltiples modalidades de experiencia resultantes de cada taller suelen saturar la taxonomía de Halberstam, mostrando la gran diversidad de masculinidades disponibles y la posibilidad de apropiarnos de la posición que todas ellas comparten. No damos por sentada la relación entre los hombres y la masculinidad, así como tampoco se busca ser "hombres por un día"17 (a la manera de Torr). La metodología desarrollada pretende, por el contrario, que "por un día dejemos de ser mujeres". Las reflexiones corporales y sus efectos

17 Título del taller que Diane Torr lleva impartiendo desde 1990. 
en nuestros procesos de encarnación del género son lo verdaderamente relevante. En los talleres se exploran nuevos sentidos de la subjetividad a partir de ocupar la posición de sujeto drag king, "como representación de un identificación transgenérica [que lo que] pone de relieve es la desestructuración de la cadena identificatoria legítima para cierto orden cultural" (Sabsay, "La performance Drag” 5).

No es, pues, que en los talleres hayamos "sido hombres", pero performar masculinidades plurales, más o menos hiperbólicas, más o menos paródicas, nos ha permitido generar un espacio inédito de reflexión sobre la autenticidad de nuestras feminidades supuestamente originales y naturales. Al quitarnos de encima unas capas y ponernos otras, hemos entendido que nuestra performance cotidiana de género es tan construida, limitada y plagiada como la que producimos artificialmente en los talleres. A partir de la reflexión corporal que supone modificar tu centro, mirada, voz, manera de ocupar el espacio - y observando los cambios que se producen inmediatamente en el entorno y las interacciones que lo habitan-, hay una concienciación del proceso mediante el cual somos lo que somos, resquebrándose así algunas de las certezas que nos sostenían identitariamente.

El drag king me ha permitido concienciar cómo mi subjetividad, corporalidad y experiencia exceden, saturan y tensionan cualquier categoría identitaria. La masculinidad y lo que se socialmente le asocia (libertad de elección, autonomía, presencia, etcétera) ha dejado de ser un terreno o posición que yo perciba como inapropiable; ha dejado de ser lo ajeno o lo otro. Recíprocamente, mi "feminidad corporal" ha dejado de ser también inherente a mi genitalidad, algo inevitable e incuestionable.

Más en general, he dejado de percibir como propiedad exclusiva de cada sujeto y algo determinado por sus características sexuales, todo aquello vinculado a la feminidad, masculinidad e incluso a la heterosexualidad. Pero lejos de ser meramente discursivo, reitero, este proceso de concienciación parte de una reflexividad corporal provocada por la experiencia drag. ¿Cómo podríamos aplicar estos aprendizajes encarnados a la producción feminista de conocimiento? ¿Cómo se puede encarnar la investigación?

Entiendo al drag king como una práctica corporal en los términos de Elsa Muñiz (2010), ${ }^{18}$ que en tanto performativa, participa en el proceso de materialización de los sujetos. Pero a diferencia de otras prácticas corporales, esta no tiende a generar cuerpos dóciles

18 Elsa Muñiz (2010) las define como "los productos y los efectos al mismo tiempo que causas productoras de aquello que producen, que es el cuerpo" (Disciplinas y prácticas 47), entendido este último como complejidad, "un continuo entre la biología y la cultura [...] como punto de partida y llegada del proceso de materialización producto de la performatividad, que está dada por los discursos que producen representaciones y las prácticas corporales cotidianas y ritualizadas que producen cuerpos dóciles, maleables y controlables" (46). 
sino que irrumpe en la lógica secuencial del género, la cual pretende estabilizar al sujeto objetivándolo y adjudicándole la obligatoria coherencia entre cuerpo, género y deseo. Si bien no es capaz de transformar los cuerpos de forma definitiva, abre una brecha para la problematización de lo que es y significa la identidad de género, posibilitando así cambios conscientes en nuestra performance cotidiana.

Como efecto performativo, la técnica drag suscita una problematización corporal y subjetiva que modifica la forma de experienciar la identidad propia $y$, por tanto, de percibir y habitar el mundo. Esto vuelve evidentes cuatro procesos que conllevan un necesario replanteamiento del uso del concepto de identidad de género en términos analíticos y políticos, los cuales resultan cardinales para el análisis teórico que aquí pretendo compartir.

Mediante la performance de la masculinidad, que problematiza la performance cotidiana de la feminidad, nos percatamos de que no existe una forma unívoca de corporalidad ni de subjetividad que responda a la representación social que producen las categorías identitarias. Éstas quedan siempre desbordadas, incluso por la serie de estrategias que cualquier persona pone en juego al quedar vinculada a ideales regulatorios del género, (pues cada individuo se relaciona espontáneamente con éstos a través de una experiencia vital que los vuelve vivibles, no mediante una performance que los cite a la perfección). Al dramatizar o representar figuras de la retórica del género distintas a las que acostumbramos cotidianamente, se evidencia que toda experiencia corporal y de género tensiona las categorías identitarias.

Solo entonces se hace posible cuestionar la originalidad, singularidad y esencialidad de la propia identidad. Pues si puedo salir a la calle dragueada y ser tratada como un hombre, consiguiendo apropiarme de ciertos gestos, movimientos, sensaciones y prácticas que se asocian socialmente a la masculinidad -y si además descubro que la ocupación de esta otra posición social no me está vedada y que todo ello tiene un efecto de autenticidad-, entonces mi performance cotidiana de la feminidad no es inherente a mi naturaleza corporal ni dicha naturaleza podría manifestarse a priori. Significa, a la vez, que las posiciones estructurales de dominio no están completamente determinadas por las características de los sujetos que las ocupan, sino que por el contrario, la investidura en dichas categorías confiere ciertas características que configuran la posición misma de dominio. La posición social que ocupo nunca es fija ni está suturada, el campo social no puede quedar totalmente establecido (Mouffe y Laclau, Hegemonía y estrategia 193).

El Drag saca a la luz algo que normalmente permanece oculto en el campo de lo social, a saber, el proceso de materialización de los cuerpos mediante el cual no solamente devenimos sujetos, sino además sujetos de género, raza y clase social. Los talleres nos han llevado a descubrir que no se puede ser un "hombre a secas", y por tanto también a preguntar si puede acaso pensarse en un sujeto sin género. Más aún, ¿es posible la subjetivación fuera 
de la inteligibilidad que confieren las matrices normativas de significación relacionadas con el género, sexualidad, raza, clase e incluso la edad?

De acuerdo con Judith Butler (en su relectura de Foucault) no hay sujeto que se constituya al margen de dichas matrices. En su seno, cada uno se da su propio exterior constitutivo, ${ }^{19}$ lo que además hace que tales categorías sean contingentes e inestables, estando siempre en constante reformulación (Butler, Cuerpos que importan 63). Esta misma contingencia, de hecho, es la que produce cierto efecto de apertura, responsable en última instancia tanto de la eficacia performativa como de la brecha de posibilidad de subversión y/o resignifación (172).

Al hacer consciente la naturalización mediante la cual fijamos una identidad, aquélla pierde parte de su eficacia performativa, es decir, se debilita aquello que permite que la misma enunciación naturalizada se constituya como real (Sabsay, "El Sujeto" 161). ${ }^{20}$ La desencialización y la desnaturalización de la identidad devienen entonces un proceso de desubjetivación, que lejos de darse de forma pura, consciente y cerrada, se combina con el constante proceso de subjetivación de género en el que estamos irremediablemente insertas en tanto sujetos. Pensemos en cómo Foucault (1995) y más tarde Butler (2002 [2001]), trabajan sobre la crítica como virtud, es decir, como posibilidad de desujeción de la norma. El drag king nos permite encarnar esta crítica, reflexionarla corporalmente desde la experiencia. Es por ello que puede concebirse ya no solo como herramienta de concienciación feminista, sino también como técnica de investigación encarnada.

$\mathrm{Su}$ uso obliga a problematizar esa concepción fija y estable que se desprende de las categorías identitarias en concreto, y del concepto de identidad en general. Los excesos, tensiones, resignificaciones y el desbordamiento, cuestionan ciertos esquemas analíticos que objetivan la experiencia y producen representaciones sociales (como las identidades y la concepción de sujeto misma que les subyace), las cuales sirven a su vez de referente para la resubjetivación. En la citación cotidiana de tales referentes, los sujetos entran en un proceso infinito en el cual pierden totalmente su agencia, capacidad de contestación y posibilidades de resistencia. ${ }^{21}$

19 Es Chantal Mouffe quien recupera las nociones derridianas de supplement, trace y différance y elabora la idea de exterior constitutivo para "mostrar el carácter de relación de toda identidad y el hecho de que con frecuencia la constitución de una identidad implica el establecimiento de una jerarquía" ("Por una política” 6). Para profundizar al respecto, revisar Chantall Mouffe, 1996.

20 Para profundizar en la eficacia performativa ver Sabsay, "El Sujeto" 2009, 165-175.

21 En "Una biopolítica menor: entrevista con Giorgio Agamben" (1999), este filósofo italiano, recuperando la definición de biopoder foucaultiana, nos habla sobre la capacidad de resubjetivar que tiene la maquinaria estatal, así como de insertar al sujeto en un proceso infinito de resubjtivaciones que es el que justamente define al biopoder. 
No es que proponga el voluntarismo identitario por el que se ha criticado a Butler y a la teoría queer en tantas ocasiones, ni que obvie el carácter estructural inherente a las posiciones sociales. La propuesta es más bien que, partiendo de estas reflexiones teóricas encarnadas, la investigación feminista gane claridad sobre cómo aprehender los procesos mediante los cuales nos constituimos en sujetos encarnados y de género, con tal de evitar producir nuevamente discursos objetivantes, categorías fijas y coherencias normativas. Se trata de promover una concepción del sujeto como existencia compleja, multidimensional y encarnada, ya no meramente subyugado a los marcos de regulación social sino en diálogo y disputa con ellos, desde una reflexividad corporal radical inmersa en procesos - conscientes o no- de reapropiación subversiva de algunos de sus presupuestos y tecnologías.

Dicha concepción de un sujeto complejo y en constante movimiento, invita a pensar su imbricación con la corporalidad. Reconocido en términos de experiencia, el cuerpo en tanto corporalidad y sujeto permite hablar de una cultura encarnada (Csordas, "Embodiment" 36-37). Si el género se produce mediante una estilización del cuerpo que obedece a una ilusión de coherencia - la cual se consigue a través de la significación que confiere la matriz heterosexual (Butler, El Género 38)-, así como de una repetición reiterada de actos que materializan a los cuerpos - dividiéndolos en aquellos que importan y aquello que no-, el Drag King irrumpe poniendo en cuestión la existencia y supuesta naturalidad de un original previo a la performance drag. Esto implica desestabilizar la continuidad entre cuerpo, género y deseo, evidenciando la complejidad, inestabilidad y multidimensionalidad tanto de la identidad como de los procesos de encarnación del género.

Lo cual confirma la manera en que Butler entiende la identidad, a saber, como una ficción normativa que opera estabilizando al sujeto y haciéndolo aparecer como esa entidad estable, cuando en el fondo dicha representación no es más que el efecto de una posición adquirida por el propio sujeto. Lo interesante de irrumpir en esta operación es evidenciar cómo las posiciones del sujeto son múltiples, inestables y contingentes, al contrario de lo que la propia noción de identidad nos permite aprehender (Mouffe y Laclau, Hegemonía y estrategia 194-196). Ello no quiere decir que tales posiciones no sean estructurales, sino que en tanto que tales, su apropiación está condicionada y condiciona al mismo tiempo las performances cotidianas configuradas por las matrices no solamente de género, sino también de racialidad, clase social, sexualidad, capacidades corporales e incluso religiosidad. Pero el hecho de que esta apropiación esté condicionada normativamente, reiteremos, no implica que las posiciones sean estables ni que los sujetos no podamos reapropiarnos estratégicamente de ciertos referentes, construyendo con ello rutas de inteligibilidad que acaban resignificándolos o incluso torciéndolos. 
Esta perspectiva teórica pide replantear el modo como la propia investigación feminista emplea el concepto de género. Son numerosos y necesarios los estudios que lo abordan en tanto dispositivo regulador, normatividad, tecnología de control y sujeción. Quizá sea preciso, además, promover esfuerzos que también estudien etnográficamente las estrategias y prácticas mediante las cuales, en sus respectivos procesos de encarnación, los sujetos resisten, contestan y tensionan esa dimensión normativa en pos de existencias más vivibles.

Si bien no es posible colocarse fuera de los procesos de subjetivación o de la inteligibilidad, ese tipo de esfuerzos podría resultar sumamente estimulante al permitirnos observar la complejidad con que tales estrategias y prácticas - así como los efectos que producen - se articulan con los procesos de interpelación normativa que también nos constituyen. Probablemente, ahí encontraremos otras rutas de inteligibilización subjetiva y corporal a las que es importante atender por su potencialidad cuestionadora y capacidad transformadora.

El reto es crear herramientas que nos permitan aprehender, potenciar y analizar desde una perspectiva crítica encarnada, la multiplicidad de experiencias y prácticas implicada en los procesos de encarnación sexo-genérica que cuestionan la concepción de sujeto subyacente a las políticas sexuales contemporáneas. El drag puede ser una de ellas.

\section{Dragueando la investigación feminista: el drag como técnica de investigación encarnada}

Utilizar al drag como técnica de investigación encarnada ${ }^{22}$ nos permite analizar cómo opera el género - así como otros ejes subjetivantes, en diferentes niveles - tanto en nuestro campo de investigación como en nuestras relaciones. Hace posible reflexionar además en cómo el género atraviesa el planteamiento de nuestros proyectos, el desarrollo del trabajo de campo y la producción del análisis y escritura. Desgranar esta operación posibilita la apertura de un nivel de reflexividad crítica en torno a lo epistemológico, desestabilizando las oposiciones binarias a través de las cuales miramos y hacemos inteligible el mundo y a nosotras como parte del mismo. Utilizar al drag como técnica de investigación es poner al cuerpo en nuestros trabajos, repensar la investigación y

${ }^{22}$ La invitación a utilizar el drag como técnica de investigación encarnada va dirigida en primer lugar a las investigadoras, quienes después de vivir la experiencia en primera persona podrían a su vez llevarla a las personas con quienes cada una trabaja. Pero, principalmente, me refiero a experimentar esta técnica en el cuerpo propio como una herramienta de reflexividad. 
entenderla como práctica corporal y transformación personal, desplazarnos por las diferentes posiciones que en nuestra investigación ocupamos de una forma consciente y estratégica.

Al investigar sobre el proceso de normalización de lo trans* en la Ciudad de México y los procesos de constitución corporal y subjetiva de personas a las que dicha normalización interpela, ${ }^{23}$ la experiencia de draguearme e impartir estos talleres me ha permitido poner en tensión la frontera entre mi yo-investigadora y las personas que se han acercado a compartir mi trabajo. La desestabilización de esta oposición binaria se ha dado asumiendo la distancia y diferencia experiencial respecto a ellas, pero también desde aquellos lugares comunes que a fin de cuentas facilitan, no una apropiación de las historias ajenas, sino una conversación con ellas. De esa forma he logrado "sentipensar" lo que las talleristas relatan, intentando que mi investigación sea un lugar colectivo de producción de conocimiento situado.

Investigo lo trans* como lugar privilegiado desde el cual mostrar el carácter contingente, constituyente y constituido del género, que el drag king evidencia a través de la experiencia corporal colectiva. El objetivo no es tanto analizar los procesos de encarnación genérica (como algo de lo que podamos sacar un modelo social a extrapolar a otras identidades notrans*), sino más bien mostrar la particularidad de los procesos vivenciales de género de cada sujeto y ponerla en diálogo con la generalidad de la lógica social de una determinada cultura de género que nos atraviesa a todas (trans* o no) y con cuyos presupuestos lidiamos de una forma u otra.

Pensar el drag king como técnica de investigación encarnada incita a mantenernos en una postura crítica y de continua reflexividad respecto a nuestro propio lente analítico, indudablemente permeado por nuestra subjetividad y corporalidad. Al mismo tiempo, nos permite comprender desde el cuerpo que la producción de conocimiento en torno a la materialización de los sujetos debe virar necesariamente hacia una producción que no objetive las experiencias, que atienda a la compleja articulación entre la experiencia y sus propias representaciones, contemplando que nuestra tendencia espontánea en tanto sujetos, no es una citación perfecta de los ideales regulatorios sino la búsqueda y constante construcción de un modo de existencia vivible.

Los cuatro procesos antes mencionados (el desbordamiento constante e ineludible de las categorías identitarias, el cuestionamiento a la esencialidad y originalidad de la identidad, la toma de consciencia sobre la inexistencia de un a priori subjetivo y material,

${ }^{23}$ Investigación doctoral en el Departamento de Ciencias Antropológicas de la UAM-Iztapalapa titulada "De las transformaciones sociales a las micropolíticas corporales: un archivo etnográfico de la normalización de lo trans* y los procesos de corposubjetivación en la Ciudad de México". 
así como sobre la desnaturalización y el carácter interseccional de la identidad) pueden ser incorporados a nuestra experiencia e investigaciones por medio del drag, como presupuestos inapelables en torno al género y la identidad en la investigación feminista. Finalmente, el drag nos permite analizar las posiciones sociales como lugares contingentes y estructurales al mismo tiempo, es decir, asumir que si bien se trata de posiciones que responden a una determinada estructura de poder, la apropiación de las mismas resulta posible y contingente.

Si por un lado las representaciones que este tipo de trabajos de investigación producen pueden devenir recursos de inteligibilidad inevitablemente relacionados con lo normativo, por el otro van más allá de ello y nos permiten asumir la potencialidad de transformación que contienen los procesos de encarnación sexo-genérica. Corporalizar nuestros análisis nos permite hacer más porosas las fronteras disciplinarias desde las que pensamos, así como asumir el compromiso político en función de una transformación social y personal, que permita la desestabilización de la cultura de género binaria que invariablemente resulta excluyente y violenta a los sujetos.

Este artículo es una invitación a perder el miedo a traspasar esos límites corposubjetivos $^{24}$ recreados constantemente por los ideales regulatorios, que tendemos a encarnar y reproducir no solamente en nuestra corporalidad sino también, de manera no consciente, en los trabajos de investigación que llevamos a cabo. El drag king nos permite interrumpir estas reiteraciones que cotidianamente son responsables de la producción del género, problematizándolo y analizando el poder performativo que lo sedimenta corporalmente. Permite la dilución de fronteras corporales, el resquebrajamiento de los límites subjetivos, la apropiación y resignificación de los elementos que conforman los ideales regulatorios pero desde la torsión y la tensión de los mismos. El drag king permite el hundimiento de las certezas identitarias y, por tanto, la apertura y la posibilidad de problematizar cómo éstas atraviesan nuestras propuestas de investigación feminista.

24 En otros trabajos (Pons, "From representation" y "De las transformaciones") propongo la corposubjetivación como el proceso mediante el cual las subjetividades se van encarnando y en el que las representaciones sociales en torno al género, racialidad y clase participan performativamente de forma compleja, particular y constante. Se trata de un movimiento continuo de transformación material del complejo entramado corporal, subjetivo y cultural que implica el sujeto en relación a su contexto. De hecho, en este proceso se entrecruzan diferentes niveles de la experiencia que afectan, modelan y producen "la carne" y al mundo en el continuum que ambos constituyen. 


\section{Bibliografía}

Agamben, Giorgio. "Una biopolítica menor: Entrevista con Giorgio Agamben”. Trad. Javier Ugarte Pérez. Vacarme, n.ำ10, 1999, en línea.

Butler, Judith. El Género en Disputa. El feminismo y la subversión de la identidad. Barcelona: Paidós, 2007 [1990].

Butler, Judith. Cuerpos que importan. Sobre los limites materiales y discursivos del "sexo". Argentina: Paidós, 2002 [1993].

Butler, Judith. “¿Qué es la crítica? Un ensayo sobre la virtud de Foucault”. The Political: Readings in Continental Philosophy. Ed. David Ingram. Londres: Basil Blackwell, 2002 [2001].

Csordas, Thomas J. "Embodiment as a Paradigm for Anthropology”. Ethos, vol. 18, núm. 1, 1990, pp. 5-47.

Ellis, Carolyn; Adams, Tony E.; Bochner, Arthur P. "Autoetnografía: un panorama”. Astrolabio, n. 14, 2015, pp. 249-273.

Ellis, Carolyn y Arthur P. Bochner. "Autoetnography, personal narrative, reflexivity: research as subject". Handbook of qualitative research, eds. Norman Denzin e Yvonna Lincoln. California: Sage, 2000, pp. 733-768.

Halberstam, Jack/Judith. Masculinidad Femenina. Barcelona-Madrid: Egalés, 2008.

Foucault, Michel. “¿Qué es la crítica?”. Revista de Filosofía, núm.11, 1995, pp. 5-25.

Mouffe, Chantal y Ernesto Laclau. Hegemonía y estrategia socialista. Hacia una radicalización de la democracia. Madrid: Siglo XXI, 1987.

Mouffe, Chantal. "Feminismo, ciudadanía y política democrática radical". Feminist Theorize the Political, ed. Judith Butler y Joan W. Scott. Nueva York-Londres: Routledge, 1992.

Mouffe, Chantal. "Por una política de la identidad nómada”. Debate Feminista, vol. 14, 1996, pp. 3-13.

Muñiz, Elsa, coord. Disciplinas y prácticas corporales. Una mirada a las sociedades contemporáneas. Barcelona-Ciudad de México: Antropos, Universidad Autónoma Metropolitana-Azcapotzalco, 2010.

Pons Rabasa, Alba. "From representation to corposubjetivation: the configuration of transgender in México City”. Transgender Studies Quarterly, Translating Transgender. Tucson: Duke Press, 2016.

Pons Rabasa, Alba. "De las transformaciones sociales a las micropolíticas corporales: un archivo etnográfico de la normalización de lo trans* y los procesos de corposubjetivación en la Ciudad de México”. Tesis de doctorado, Universidad Autónoma Metropolitana-Iztapalapa, 2016. 
INVESTIGACIÓNTEATRAL

Revista de artes escénicas y performatividad

Vol. 9, Núm. 13

abril-septiembre 2018
Los talleres Drag King: Una metodología

feminista de investigación encarnada

Alba Pons Rabasa

Preciado, Beatriz. "Género y performance (tres episodios de un cybermanga feminista queer trans...)". Revista Zehar, núm 54, 2004, pp. 1-14.

Sabsay, Leticia. "La performance Drag King: usos del cuerpo, identidad y representación". Revista Questión, núm. 12, 2006, en línea.

Sabsay, Leticia. "El Sujeto de la Performatividad: Narrativas, Cuerpos y políticas en los límites del género". Tesis de doctorado, Universidad de Valencia, 2009.

Taylor, Diana. Performance. Buenos Aires: Asunto Impreso, 2012.

Torr, Diane y Stephen Bottoms. Sex, Drag and Male Roles. Investigating gender as performance. Michigan: University of Michigan Press, 2010.

Volcano, Delagrace y Jack Halberstam. The Drag King Book. Londres: Tail, Serpent's, 1999. 


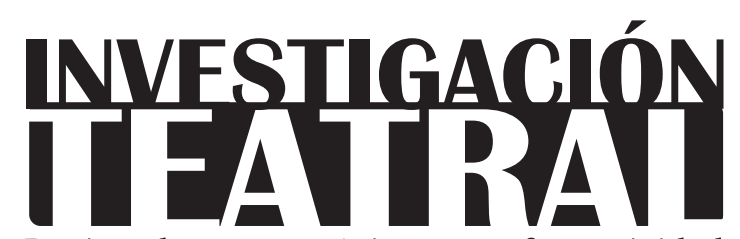

Revista de artes escénicas y performatividad

Vol. 9, Núm. 13

abril-septiembre 2018

Segunda época

ISSN impreso: 1665-8728

ISSN electrónico: 2594-0953

Universidad Veracruzana

\title{
El cuerpo del/la boxeador/a: danza y representación
}

\author{
Hortensia Moreno*
}
* Centro de Investigaciones y Estudios de Género, Universidad Nacional Autónoma de México, México. e-mail: hortensia_moreno@cieg.unam.mx

Recibido: 30 de agosto de 2017

Aceptado: 01 de diciembre de 2017 


\title{
El cuerpo del/la boxeador/a: danza y representación
}

\section{Resumen}

A partir del video Round en la sombra (2007), dirigido por Alfredo Salomón, reflexiono acerca de los recursos semióticos corporales de dos campos contrastantes: el boxeo y la danza. Trato de poner en contexto el poder de significación que se despliega en la exhibición del cuerpo semidesnudo en el cuadrilátero. Como coreografía cuidadosamente ritualizada, esta representación persigue la producción performativa de la masculinidad, en oposición a la que le servirá de referente y límite: la del cuerpo de la boxeadora como contradicción y reafirmación de la ofrenda escenificada en la pelea. Las prácticas corporales de estas dos disciplinas me sirven como pretexto para discutir la exclusión de las mujeres del campo deportivo.

Palabras clave: boxeo, danza, performatividad, performance, género, México.

\section{The Boxer's Body: Dance and Representation}

\begin{abstract}
Using Round en la sombra (2007), a video directed by Alfredo Salomón as a basis for discussion, I examine the semiotic bodily resources of two contrasting fields: boxing and dance. My intention is to contextualize the signifying power deployed in the exhibition of the half-naked body on the ring. In a carefully ritualized choreography, this representation contributes to the performative production of masculinity in opposition to that of the female boxer's body - its model and limit - which works as both contradiction and reaffirmation of the sacrifice staged at the fight. With the physical practice of these two disciplines in mind, I discuss the exclusion of women from the sports' field.
\end{abstract}

Keywords: box, dance, performativity, performance, gender, Mexico. 


\section{El cuerpo del/la boxeador/a: danza y representación}

\section{Preámbulo}

ound en la sombra (2007) fue filmado a partir de una idea de Patricia Camacho
Quintos, quien en 2007 publicó la novela Danza y box: bálsamo y herida. A pesar
de ser un producto derivado del trabajo literario, el video en sí mismo posee una alucinante capacidad expresiva. El ejercicio videográfico - tributario de una correcta apropiación del lenguaje cinematográfico- se organiza alrededor de la contraposición de dos tipos de técnicas corporales: por un lado, las deportivas (específicamente las del boxeo), y por el otro, las de la danza escénica contemporánea. El reto para Gilberto González, ${ }^{1}$ bailarín, es el de replicar la estructura visual de la locomoción pugilística; el reto para Dante Jardón, boxeador, es mostrar en el cuadrilátero esa misma estructura sin producir los efectos "reales" de la confrontación (o sea, sin noquear al bailarín).

${ }^{1}$ Gilberto González es un bailarín y coreógrafo muy particular, define su trabajo como danza-teatro del gesto, se ha entrenado con técnicas de danza contemporánea, pantomima y teatro. Ganó varios premios nacionales como bailarín y coreógrafo de la compañía Onírico danza-teatro del gesto y trabajó dos años en el Cirque du Soleil. Gloria Godínez (2018), especialista en teoría de la danza, cree que "la habilidad gestual con la que Gilberto ha decodificado o deconstruido el lenguaje del boxeo hasta convertirlo en una coreografía es especial, no cualquier bailarín podría haberlo hecho" y agrega que "gracias a la yuxtaposición de lenguajes inscritos en los cuerpos de bailarín y boxeador, así como a la edición de video y la música, Alfredo Salomón nos ofrece al final un híbrido video-danza-box muy interesante" (Godínez, conversación). 
La actuación profesional de esos dos cuerpos obedece a lógicas distintas, pero confluye en varios puntos. Se trata, en ambos casos, de cuerpos altamente especializados, resultado de largos procesos de aprendizaje donde han sido sometidos a disciplinas rigurosas, y cuyos rendimientos equivalen a niveles muy altos de destreza, fuerza, coordinación y resistencia. Uno de los puntos nodales de la práctica boxística es la organización de ese conjunto de coordinaciones motoras en función del ritmo. Entre los vínculos que pueden establecerse entre el boxeo y la danza está la idea de que "un boxeador necesita ser un buen bailarín", como la expresa, por ejemplo, el entrenador cubano Miguel Baro (cit. en Palma 15). Además, tanto el boxeo como la danza obedecen al marco social del espectáculo, es decir, se trata de prácticas escenificadas y, en esa medida, se puede afirmar que son performáticas. ${ }^{2}$ No obstante, el involucramiento del cuerpo como lugar específico de la representación nos obliga a dibujar una línea muy fina y porosa entre recursos semióticos (aquellos que se utilizan con la finalidad específica de significar) y actos materiales.

Dichos puntos de confluencia constituyen uno de los ejes de mi reflexión: en tanto se trata de dos disciplinas "diametralmente opuestas", el boxeo y la danza construirían cuerpos visiblemente distintos. Lo que el video muestra es la afinidad entre el cuerpo de un bailarín y el de un boxeador; afinidad que llega al extremo en que ambos se confunden y se vuelven prácticamente indistinguibles. ${ }^{3}$

Desde luego, esta confusión es artificial (y en esa medida performática). Se trata de dos especializaciones que no permiten que estos cuerpos "hagan lo mismo": el boxeador — con su nivel de preparación actual - sería incapaz de las precisiones de la danza contemporánea (por ejemplo, no podría girar y rodar con los pies descalzos como lo hace el bailarín). ${ }^{4}$ Por su parte, el bailarín es incapaz de propinar o de "absorber" un golpe como lo hace el boxeador. No obstante, a pesar de la apariencia de "ingravidez" propia de la danza, el cuerpo del bailarín

${ }^{2}$ Utilizo la noción de lo "performático" para distinguir, en el plano de la significación, los contenidos que se derivan de la práctica teatral de aquellos relacionados con el denominado "performance", pensado en sentido amplio como un lugar de representación cuya principal característica es su dimensión de acontecimiento, es decir, su carácter único e irrepetible, a pesar de ocurrir en el contexto de la sociedad y la cultura -lo cual media ese carácter pero no lo suprime-. Lo performático pertenece al ámbito de la representación escénica sin sujetarse de manera rígida a la normatividad de lo teatral, pero puede ser examinado a la luz de la reflexión acerca del performance (véase, por ejemplo, Schechner, Performance Studies; Prieto, "En torno a” y “iLucha libre!”; Slaughter y Moreno, Representación y fronteras).

${ }^{3}$ Se trata, por supuesto, de un boxeador de peso ligero; seguramente el símil deja de funcionar conforme nos acercamos a la constitución de un boxeador de peso completo.

${ }^{4}$ Una de las escenas del principio del video nos advierte de manera sutil acerca de esta diferencia: mientras que el boxeador se venda las manos, el bailarín se venda los pies. 
es equivalente en términos de fuerza o musculatura al del boxeador. Las semejanzas entre las dos disciplinas son relevantes en la medida en que se trata de maneras análogas de producción del cuerpo como materia prima tanto de la acción humana como de su representación, en un juego visual donde se evidencia la imposibilidad de separar estos dominios.

De manera particular, es dentro del marco social del espectáculo donde la diferencia entre "hacer" y "representar" se vuelve más difusa. ${ }^{5}$ El concepto de performatividad nos ayuda aquí en la medida en que lo extendamos del espacio de lo lingüístico al espacio de lo ritual, para lo cual hace falta insistir en que la separación abstracta entre lo lingüístico y lo concreto existencial sólo se da en términos conceptuales. La palabra sólo tiene existencia en el cuerpo y en la materialidad específica del contexto donde ese cuerpo existe; por lo tanto, la producción de sentido excede lo lingüístico en la medida en que hay procesos de semiosis completamente deslindables de la palabra: signos que residen en el cuerpo y recursos semióticos diferentes del cuerpo, pero que lo acompañan de una manera tan estrecha que resulta difícil distinguirlos de la corporalidad.

Por eso se puede afirmar que la performatividad no se reduce al lenguaje que actúa, sino que incluye a la acción que significa (Hollywood 256). La acción significativa implicada en la idea de ritual nos llama la atención sobre la performatividad de prácticas corporales que no son lingüísticas. He aquí una afinidad más entre el boxeo y la danza: se trata de dos disciplinas altamente ritualizadas donde los cuerpos se ofrecen a la mirada como ofrendas. ${ }^{6}$

\section{Cuerpo, género y boxeo}

Los estudios del deporte permiten abordar una amplia gama de temas relacionados con el cuerpo, el género y las relaciones sociales. ${ }^{7}$ Uno de los enfoques para este tipo de investigación es el semiótico, que busca dilucidar los mecanismos de significación

${ }^{5}$ En performances como el de la lucha libre, esta indistinción se vuelve más evidente: ¿hasta dónde está fingiendo un performer que se produce hemorragias en la cara para dramatizar el espectáculo?

${ }^{6}$ Para una reflexión más amplia sobre el ritual y la performatividad véase: Turner, The Anthropology; Yébenes, "Performatividad, prácticas corporales"; Moreno y Torres, "Performatividad" (en prensa).

${ }^{7}$ Entre los autores más importantes que han revisado el problema del deporte en el contexto del género y la masculinidad, particularmente orientados al estudio del boxeo, están: de Garis, "Be a Buddy"; Downing, "The Gentleman Boxer"; Hargreaves, "Sporting Females"; Lafferty y McKay, "Suffragettes in Satin"; Wacquant, "The Social Logic”; Woodward, "Boxing Masculinity”. Para una perspectiva sociológica sobre la vinculación entre cuerpo y deporte se puede consultar: Elias y Dunning, Deporte y ocio; Goffman, "The Arrangement”; Bourdieu, "Sport and Social Class” y “¿Cómo se puede ser deportista?”. Una mirada sociohistórica puede verse en Vigarello, "Ejercitarse, jugar"; Moreno, "La invención”. 
y representación a partir de los cuales se constituyen los discursos y las imágenes que pueblan un campo social. La relevancia para el conjunto de la vida social de los discursos e imágenes que tienen lugar en un espacio particularmente acotado - en este caso, el campo deportivo-, radica en que éste funciona como una caja de resonancia donde se produce y reproduce el orden simbólico en prácticas, metáforas y figuraciones en las que el cuerpo, pensado como un lugar privilegiado de semiosis, desempeña un papel primordial.

El boxeo, como institución deportiva específica, presenta afinidades y rupturas con el campo deportivo en general. Su enorme riqueza semiótica permite esclarecer no sólo construcciones imaginarias propias de una práctica social cuya codificación es intensiva, sino también representaciones sociales hegemónicas de la vida mundana. El foco del presente ensayo tiene que ver con las formas en que los cuerpos sexuados significan y se significan en el escenario brutal del cuadrilátero para convertir la violencia de la confrontación física - cuya finalidad expresa es la destrucción del cuerpo del otro- en una alegoría de la vida y, al mismo tiempo, en la marca semiótica por excelencia de la masculinidad.

Es decir, la producción simbólica del cuerpo del boxeador se verifica dentro de un marco de normas y valores que contiene, histórica y tradicionalmente, la función de producir masculinidad. La irresoluble aporía que representa el cuerpo de la boxeadora descuadra la maquinaria semiótica del boxeo sin interrumpir su marcha, de la misma forma en que el juego del bailarín señala este territorio con su imposibilidad para ocuparlo; no en vano, entre las disciplinas del cuerpo, la danza escénica aparece como una actividad agudamente feminizada, atribución que inclusive pone en entredicho la identidad sexual de los pocos y sobresalientes varones que se atreven a practicarlo.

No obstante esta clara separación de espacios, los mecanismos de exclusión funcionan de maneras difusas. La institución requiere un sofisticado conjunto de estrategias para admitir la presencia del sujeto que mediante su ausencia en dicha institución, la define. La admisión de las mujeres en el boxeo, por ejemplo, se convierte en un dispositivo que a la vez niega y afirma su principal enunciado en una arena social diversa y compleja. Lo que revelan esas estrategias discursivas y performáticas es el carácter difuso y cambiante de los valores de género. En lugar de tratarse de estructuras fijas, fundadas en hechos "naturales", los rasgos atribuidos a los cuerpos y sus actos en el imaginario del género (gender) son producto de interpretaciones culturales siempre en disputa y negociación. 


\section{La fuerza física en la construcción performativa de la masculinidad}

El género existe performativamente en sus encarnaciones, pero siempre en estrecha relación con interpretaciones culturales abstractas que se construyen a partir de factores muy diversos. La entronización de los significados actuales de la(s) masculinidad(es) tiene lugar en un contexto histórico determinado: el de los albores de la modernidad. Construida a partir de una tradición antigua, el símbolo que encarna el deportista a finales del siglo XIX y durante todo el siglo xx responde a una lógica que enlaza dos épocas distintas y contrastantes. Por un lado, está la figura del "caballero", representante de un ideal corporal donde se combina el uso de la fuerza bruta con la cortesía (Downing, The Gentleman Boxer). En el inicio de este proceso, hay una asociación imaginaria entre la fuerza física - como capacidad para derrotar a un adversario mediante el uso de la violencia - y la supremacía de la aristocracia medieval como clase dominante. Por el otro lado aparece la necesidad de diferenciar los papeles y los espacios sociales que constituirán las esferas de acción de mujeres y hombres como dos ámbitos incontrastables.

La lógica de la caballería, como institución fundamentalmente militar - y a la vez profundamente atravesada por elementos míticos-, supone una exaltación de la potencia corporal, de la habilidad en el manejo de las armas y de la imposición del derecho del más fuerte como el principal mecanismo de la organización social. No obstante, la modernidad necesita dulcificar y romantizar el derecho del más fuerte mediante el código de caballería, que lo postula como un instrumento de la justicia, la defensa del débil, la valentía, el honor y el refinamiento cortés. Esta vuelta de tuerca adquiere pleno sentido cuando se vuelve la base de la construcción de la masculinidad plebeya y se extiende al imaginario abstracto del "hombre", postulado por el Iluminismo como el sujeto de razón que engloba al género masculino más allá de las particularidades de clase.

De esta forma se legitima una nueva manera de leer la hombría, orientada por una cultura corporal que, durante el Renacimiento, rige la educación del caballero y del cortesano, en contraste con "la diversidad poco categorizada y exclusivamente guerrera del final de la Edad Media", para dar lugar a una concepción del mundo donde el poder de las armas deberá ceder su predominio a la vida civil. Los referentes simbólicos de este amplio desplazamiento - entre principios del siglo XVI y mediados del XVII- "de la fuerza hacia la prestancia, de la potencia hacia la destreza", estarán directamente anclados en el cuerpo, pero requerirán un programa de habilitación que permita enseñar y aprender la elegancia aristocrática, el porte, la distinción (Vigarello, "Ejercitarse, jugar" $244,246)$. 
La modernidad introduce, así, un proyecto pedagógico que se orienta a la codificación de las habilidades corporales, constitutivas del habitus de la nobleza, en una creciente conciencia de la importancia de los saberes del cuerpo. De manera por demás interesante, es precisamente en ese contexto donde aparece la danza en la corte de Luis XIV. Las cortes europeas se convertirán en espacios intensamente teatralizados para el aprendizaje de las actitudes, el dominio físico y los gestos que permiten ingresar en "la vida mundana en una sociedad de representación" (251). En Francia, en los albores de la modernidad, "el vigor corporal y su manifestación siguen siendo un signo de poder" (230); no obstante, el acento se desplaza de la expresión física de la fuerza hacia el refinamiento de la pose y la indumentaria y hacia la creación de un auténtico arte de corte para llegar a "una cultura corporal nueva de los nobles en la Francia clásica" (ibíd.). El origen de todo un rango de disciplinas - justas y torneos, juegos de lanza - está vinculado con el ethos guerrero como privilegio aristocrático. Pero este ethos se vuelve cada vez más ficticio conforme avanza el proceso civilizatorio.

De ahora en adelante, el apaciguamiento de la violencia tendrá que pasar por su morigeración mediante las instituciones que la organizan y reglamentan. De esta forma, la modernidad parece recuperar, de manera velada, una sublimación de la fuerza bruta, aunque tal legitimación - que contradice flagrantemente el ideal ilustrado de que "la fuerza no hace derecho" - requiera aún otra operación retórica: la de atribuir — siempre en el terreno de lo imaginario- el privilegio de la fuerza a los varones para privar al "sexo débil" de todo reclamo relacionado con la fuerza física.

Es aquí donde aparece la cultura boxística: en el mismo movimiento donde la identificación de la burguesía en ascenso con los valores de la aristocracia recoge la inclinación que el mundo de la corte había teatralizado sin desligarla de su origen guerrero. En el contexto del ideal ilustrado, la institucionalización del boxeo contiene la intención explícita de masculinizar a los jóvenes. Aquí se recupera el sentido de defender el propio honor con los puños como una noción tradicional de hombría, asociada, además, con una cultura que se definía mediante el combate, en una nación - la británica - que en el siglo XVIII estaba construyendo un imperio y pagando varias guerras, de modo que el Estado requería hombres capaces de portar armas y entrenados en la violencia:

El código de honor del boxeo [...] tiene vínculos con estatus de clase más elevados, por ejemplo, con la defensa personal, incluida la pelea con los puños [fist fighting] y, notablemente, las habilidades para el duelo, que eran parte del repertorio de los jóvenes caballeros en el siglo XVIII [...]. El pugilismo combina la aprobación institucionalizada del combate corporal - como un medio legítimo y moralmente aceptable de resolver disputas- con la justificación personal y la afirmación de la identidad, o más específicamente, de la masculinidad. No hay tal espacio para la afirmación de la feminidad. La 
asociación de los hombres con la guerra es un factor que contribuye a esta exclusión (Woodward 28-29). ${ }^{8}$

La reglamentación del boxeo — paso decisivo de su deportivización $-{ }^{9}$ exige la exclusión de las mujeres porque en el centro de su constitución está la necesidad de determinar las cualidades del "hombre verdadero" y la demanda de una identidad masculina apropiada y obligatoria para todas las clases sociales, asociada con la encarnación de la maestría física, la conducta caballerosa, la moral varonil y el entrenamiento del carácter. De esta forma, los deportes, en general, y el boxeo, en particular, se convierten en símbolos de la masculinidad al corporificar despliegues agresivos de poder físico y competitividad: "En el siglo XIX no había duda de que los deportes fueran el dominio 'natural' de los hombres ni de que 'ser bueno' para los deportes fuera esencialmente 'masculino"' (Hargreaves 43). La masculinidad, en este contexto, debe ser entendida como un proceso imaginario que permite crear un terreno común para "la aspiración del peleador al estatus de caballero y el deseo del caballero de ser capaz de pelear" (Downing 12-13).

\section{Fuerza / belleza}

Hay una interpretación mística del boxeo, la cual inspira una producción cultural bastante extensa - sobre todo en su versión pop - en cine, televisión, cómic, narrativa y periodismo. A partir de esta visión se elabora una figura heroica que se mueve en el mundo boxístico para fabular mitos de la modernidad, como el de la construcción de la masculinidad, la conversión del niño en hombre o la salida de la pobreza con base en el mérito individual. En todas estas expresiones, el boxeo "es conquista y destrucción, competencia pura, hombre contra hombre" (Hauser 7).

\footnotetext{
8 "Boxing's encoding of honour also carries strongly classed dimensions [...] it has links with more elevated class status, for example with self-defence, including fist fighting, and notably, duelling skills, being part of the young gentleman's repertoire in the eighteenth century [...] Pugilism combines institutionalized approval of corporeal combat as a legitimate and morally acceptable means solving disputes with personal justification and affirmation of identity, or more specifically, masculinity. There is no such space for the affirmation of femininity. The association of men with warfare is one contributory factor to this exclusion" (Woodward 28-29).

${ }^{9}$ Utilizo esta noción en el sentido en que la ha desarrollado Elias, la deportivización del boxeo transcurre por un largo proceso que lo conduce finalmente a su institucionalización y establecimiento mundial como disciplina reglamentada.
} 
En su Historia de la belleza, Georges Vigarello ubica el origen de algunos de los elementos significativos de estas mitologías en la Europa del Renacimiento. Según este autor, en ese momento crucial se inauguró una nueva concepción del género, donde se establece por primera vez la distribución universal y abstracta de cualidades femeninas y masculinas que predominará durante la modernidad. Es entonces cuando aquella "inicial belleza moderna sólo se define en femenino, combinando inevitablemente debilidad y perfección" (Vigarello 28). El cambio cultural, al tiempo que porta una valorización inédita del estatus de las mujeres, encierra la paradoja de que esa nueva apreciación "no pueda superar la oscura y reiterada certeza de una inferioridad" (ibíd.):

Un reparto se establece aquí, orientando claramente, y durante mucho tiempo, a los géneros hacia dos cualidades opuestas: la fuerza para el hombre, la belleza para la mujer; para uno "el trabajo en la ciudad y en el campo", para la otra "las tareas de la casa". [...]. La mujer sigue siendo inexorablemente "inferior", tanto más dominada en cuanto su belleza está hecha para "regocijar" al hombre o, mejor aún, para "servirlo". Creada para el otro, sigue siendo pensada para él (Vigarello, Historia de la belleza 30,34).

A partir de entonces, los temperamentos sexuales se reinterpretan de manera tal que la fragilidad -identificada ahora como "femenina" y, por lo tanto, como rasgo categórico de la condición de "mujer" - se vuelve "graciosa como nunca antes" (Vigarello 32), mientras que los varones se ven obligados a una asunción física particular, donde se subrayan la dureza, la severidad y la potencia. Esta asignación de virtudes no se generaliza de inmediato ni uniformemente, pero hacia finales del siglo XVIII está muy cerca de constituir el sentido común sobre el género.

En su origen, se trata obviamente de un atributo de clase; sin embargo, conforme la atribución se universaliza en los binarios masculino/femenino, hombre/mujer, el ideal de fragilidad empieza a funcionar en el imaginario social como una característica relacionada con la belleza "en abstracto" (a pesar de que las mujeres de las clases trabajadoras no se puedan dar el lujo de ser débiles). No obstante, en abyecta contradicción con la experiencia, la ideología de la clase dominante termina por convertirse en la ideología dominante, a partir de una investigación anatómica que estrenará una nueva manera de mirar el cuerpo:

[E]1 Iluminismo reinventó la lógica de la estética femenina y la lógica del poder masculino. El esqueleto impondría su dictado: el único destino de la mujer sería la maternidad. Esto descalifica los viejos razonamientos morales sobre la inferioridad femeni- 
na, la ternura de su temperamento, su debilidad íntima, legitimando su dependencia por la naturaleza de sus "funciones". La mujer no sabría enfrentar las cosas porque es exclusivamente responsable de engendrar y de criar a su prole. No sería capaz de participar en la vida pública para hacer prosperar mejor la infancia y la vida privada (Vigarello, Historia de la belleza 106).

La reclusión de las mujeres en el ámbito doméstico se conjugará, entonces, con esta interpretación de su potencial biológico. A partir de este momento, la heteronomía de las mujeres se explicará a partir de la constitución de su débil corporalidad, destinada al embarazo, el parto y la crianza. Y su sometimiento a los varones - en un mundo que se abría a la libre determinación individual y al reconocimiento de los demás individuos como semejantes - se justificará como la consecuencia "natural" de tal debilidad en este peculiar reducto de lo humano que queda, desde entonces, directamente relacionado con la biología, con la materia, con la animalidad. Si en el mundo moderno se postula que la fuerza no hace derecho (Serret, Identidad femenina; Laqueur, La construcción del sexo), en las relaciones entre mujeres y hombres se introduce una difícil excepción: la "superioridad natural" de los varones - manifestada como fuerza corporal, como poderío físico enfrentado a la debilidad inmanente de las hembras - legitima su dominio sobre las mujeres.

Hay una segunda consecuencia - de enorme relevancia para el tema que nos ocupade esta repartición de atributos: la interpretación de las mujeres como cuerpos destinados a la maternidad limita, desde ese momento, su capacidad de decisión. Las mujeres no pueden disponer libremente de sus cuerpos porque sus cuerpos no les pertenecen, sino que son solamente el vehículo para un fin más alto que ellas mismas: "la tendencia de la teoría inicial del contrato es hacer que la subordinación de las mujeres a los hombres sea resultado del funcionamiento de los propios hechos de la diferencia sexual, de sus implicaciones utilitarias [...]: los cuerpos no son el signo, sino el fundamento de la sociedad civil" (Laqueur 270-271)..$^{10}$

Por eso se vuelve tan perturbadora la imagen de una mujer fuerte; por eso hace falta reprimir, desnaturalizar, ocultar, ridiculizar las pretensiones deportivas de las mujeres. Y es especialmente en el boxeo donde esta divergencia se convierte en un vigoroso marcador de género. Porque el boxeo, de manera singular, recupera el valor de la fuerza bruta y lo enaltece en un nicho de exclusividad celosamente resguardado.

10 Cursivas en el original. 


\section{Cuerpo, danza, representación}

El significado del cuerpo del boxeador se ve atravesado por múltiples factores, todos ellos relacionados con la definición de la masculinidad: hay diferentes formas de expresión de la masculinidad que se reproducen en el campo específico del boxeo. Para Laurence de Garis, la masculinidad "a menudo se pone a prueba en un mundo homosocial con otros hombres" (9495). Oates habla del ataque y la sumisión absoluta del otro como reacción del ego masculino — una respuesta "que depreda la civilización" - más allá del instinto de defenderse (49).

Para Kath Woodward, las técnicas corporales y el régimen físico del entrenamiento a menudo implican "la habilidad de controlar el dolor y ejercitar la disciplina y el auto-control, los cuales operan no sólo internamente, sino que son parte de lo que constituye la masculinidad en términos temporales y espaciales" (86-87). Para Robert Anasi, un nocaut — "mandar a alguien a la lona" - significa arrebatarle la hombría (101). Para Thomas Hauser, el varón está obsesionado con la victoria (7). Para Loïc Wacquant, la cultura del gimnasio es un espacio quinta esencialmente masculino, "dentro del cual la entrada de mujeres sólo es tolerada en tanto en cuanto sea incidental" (234). Según Yvonne Lafferty y Jim McKay, los boxeadores obtienen prestigio y poder en la medida en que pertenecen al minúsculo grupo de varones que "literalmente corporifican la masculinidad hegemónica" (252). En cambio, las boxeadoras - que al exhibir agresión y fuerza "desafían los ideales de la feminidad enfatizada" - por lo general "aparecen en las peleas de relleno y gozan, para el desarrollo de su trabajo, de una pequeña fracción de los recursos que los pugilistas varones tienen garantizados" (ibíd.).

En este contexto, la masculinidad adquiere un estatuto difuso, pantanoso. Se trata de una arena de significación siempre en proceso, incapaz de establecer contenidos fijos. No obstante, existe una organización imaginaria -y por tanto derivada del orden simbólico- que estructura la producción semiótica fundamentalmente alrededor de los ejes que codifican el género.

Esa codificación es performativa. La performatividad implica dos características principales: 1) se trata de una figuración cuyo soporte material es un acto, 2) el acto es auto-referencial. Cuando hablamos de la construcción de significados en una disciplina del cuerpo, la definición del acto no está anclada exclusivamente en los enunciados lingüísticos, sino que el espacio de lo performativo abarca la corporalidad en su conjunto: movimiento, forma, ritmo, peso, color, luz, trabajo, inercia. Un acto es performativo en la medida en que es significativo/ritual y acata condiciones de validez respecto de la persona que los lleva a cabo y las circunstancias de la puesta en acto. ${ }^{11}$

11 Para reflexiones acerca de la ritualidad, el cuerpo y la performatividad puede leerse: Yébenes, "Performatividad, prácticas corporales"; Butler, "Afterword"; Demaria, "The Performative Body"; Felman, The Scandal; Markula, "Body-Movement-Change"; Pilgrim, "Performance"; Scott, "How to Look". 
Respecto de la condición de auto-referencialidad, decimos que el acto performativo tiene la propiedad de ser un acto individual, único, histórico e irrepetible: "No puede ser efectuado más que en circunstancias particulares, una vez y una sola, en una fecha y un lugar definidos [...]; es acontecimiento porque crea el acontecimiento" (Benveniste 194-195). Para Benveniste, la consecuencia de este hecho es que el significado es idéntico al referente, es decir, el acto performativo se refiere "a una realidad que él mismo constituye" (195). Decir que la masculinidad es performativa equivale a decir que se constituye a sí misma en su propia escenificación; pero, como lo ha señalado Butler (Cuerpos 34), al tiempo que se constituye, oculta o disimula las convenciones de las que es una repetición; la "magia performativa" opera en la medida en que el acto significante consigue, por un lado, delimitar y circunscribir el cuerpo, y, por el otro, postular que el cuerpo es anterior a toda significación.

A su vez, el carácter performativo del género se manifiesta en su falibilidad. En efecto, la performatividad de género adolece todas las fallas que aquejan a los actos: la posibilidad de que fracase no es accidental, "sino que el fallo forma parte constitutiva de la vida misma del performativo. Es ahí, en el fracaso, donde el performativo abre el espacio para la agencia del sujeto" (Burgos 254).

El fracaso, el fallo, la pifia, la posibilidad de cebarse, agrupados por Austin en la noción de infelicities o infortunios, ${ }^{12}$ dan cuenta, por un lado, de la enfermedad de la cual todos los actos convencionales son herederos; pero, por el otro, dan cuenta de la artificialidad del género, de la posibilidad de actuar profunda, auténticamente, la identidad "equivocada". En efecto, la capacidad performativa de representación de la masculinidad - o de la feminidad- hace residir en el acto - en la escenificación, ceremonia, ritual, performance-, y no en el cuerpo - biología, fisiología, configuración anatómica-, la condición para la verosimilitud de la identidad de género. De modo tal que un cuerpo de mujer podría representar cabalmente la masculinidad de manera tan convincente que quien la actuase tuviera la certeza de su adscripción al grupo de los varones. ${ }^{13}$

Ahora bien, también en el campo del boxeo la condición de ser único e irrepetible anida en la estructura convencional del acto codificado social y culturalmente: el significado del acontecimiento sólo tiene lugar en un marco solemne y ceremonial. Ninguno de los actos, ninguno de los gestos que componen el acto, tiene sentido fuera del contexto abigarrado y riguroso de la competencia ritual. Lo que se pone en acto no es la pura fuerza muscular, la sola habilidad corporal o el severo entrenamiento, sino el conjunto del acto boxístico en toda su complejidad.

12 Austin, J. Cómo hacer cosas con palabras. Buenos Aires: Paidós, 1971.

13 Agradezco a Rodrigo Parrini la discusión que generó estas reflexiones. 
Veamos: el campo del boxeo es performativo en tanto se trata de un espacio de institución; como explica Bourdieu (Language E Symbolic), el trabajo de institución — de institutere, institutio - implica un acto inaugural de constitución, de fundación, de invención; el cual, mediante el proceso educativo, conduce a disposiciones, hábitos o usos permanentes. En cada acto de institución hay una minuciosa repartición de lugares, tareas, funciones, autoridades. ${ }^{14}$ Repartición codificada de manera puntual mediante signos (actos) visibles, unívocos, convencionales: un lugar para cada actor y cada actor en su lugar, cada uno ataviado con la vestimenta que le corresponde - en obediencia de una estricta etiqueta - y dispuesto a recitar en el instante preciso las líneas que le corresponden en el script general. La arena organiza la acción en tanto distingue con claridad impecable la función del espacio en cada uno de sus puntos: desde los vestidores hasta las gradas, desde la sala de prensa hasta las taquillas, desde los corredores por donde pasarán los contrincantes hasta las filas reservadas para los espectadores VIP, ostentosamente engalanados.

El cuadrilátero es un escenario que permite, dentro de la inmensa gama posible de la expresión corporal, un rango limitado de acciones. Cada acción tiene un significado y está asociada con un actor autorizado y una serie de condiciones de autenticidad. La validez de los actos queda anotada en los registros oficiales. El performativo puro de la declaración de triunfo - "el ganador de esta pelea..."- está inmerso en una intrincada puesta en escena donde no se logran identificar factores insignificantes.

El tiempo del boxeo es uno de los marcos materiales más significativos del acto. El calendario, el horario, la programación, las decisiones que categorizan los encuentros "de relleno" respecto de la pelea principal, planifican el encuentro en el tiempo grueso de los días y las horas. Seguidos por reflectores, los contendientes atraviesan el largo camino entre los vestidores y el cuadrilátero en medio del griterío de la afición y los flashes de las cámaras fotográficas. No hay aficionados imparciales; el campo es maniqueo: blanco o negro, azul o rojo, bien o mal:

Ahí es donde está la gran exaltación de la razón en el boxeo. Quienes defendemos o hemos defendido el boxeo en algún momento llevamos la idea de la ficción a la idea de que, si se confrontan dos cuerpos potencialmente idénticos, la supremacía es en realidad la gran realización estratégica. El box es el triunfo de la razón estratégica, la gran visibilidad de la razón estratégica [...]: en el box se da el encuentro de las

14 "La eficacia mágica de estos actos de institución [los enunciados performativos] es inseparable de la existencia de una institución que defina las condiciones [...] que deben reunirse para que la magia de las palabras pueda actuar" (Bourdieu, ¿Qué significa hablar? 46). 
potencias puras en confrontación. Las potencias puras en una condición de equiparación cuya única posibilidad de resolución es la supremacía estratégica (Mier, entrevista). ${ }^{15}$

Desde el momento de su aparición, el combatiente danza. Cubierta la cabeza por la capucha de su bata, acompañado de su equipo, rodeado por una corte de fanáticos y periodistas, el boxeador trota, mueve el cuello, levanta los hombros, muestra los puños, saluda al público con la mano en alto. Finalmente, sube al cuadrilátero haciendo gala de agilidad y deja atrás a la muchedumbre anónima. Cada movimiento está codificado; sólo los boxeadores se mueven así; dentro de ese marco, ninguna otra persona está autorizada a hacerlo. ${ }^{16}$

En el centro de la arena se levanta el cuadrilátero, foco de todas las miradas. El escenario está profusamente iluminado, mientras que el graderío permanece en penumbra. En la preparación del combate sólo participan el presentador, el réferi y los propios peleadores, cada uno acompañado de su mánager y uno o dos seconds. El ring es significativamente territorial: dos de las esquinas son neutrales y cada una de las restantes pertenece a un contendiente. El inicio es confuso y aparentemente desordenado. Los peleadores transitan del banquillo al centro del ring, cuidándose quizá de no invadir aún la circunscripción del enemigo.

Mánagers y seconds administran su parafernalia: una cubeta, un botiquín, una toalla. Masajean los pectorales y los gemelos del boxeador. Le susurran frases al oído. El peleador mira al adversario en actitud retadora y sigue danzando mientras el réferi inspecciona el vendaje y los guantes. La pelea ha empezado semanas, quizá meses antes de la fecha de su verificación, desde el momento de su anuncio, de manera relevante en la ceremonia de pesaje. Los rivales se han visto, se han medido con la mirada, se han seguido en los medios. Ahora se encontrarán, en efecto. Exactamente antes de comenzar el combate, se miran y actúan su desprecio mutuo.

$\mathrm{Al}$ ascenso de los boxeadores pueden seguir innumerables rituales dilatorios. El boxeo es un encuentro de dos cuerpos desnudos que se regocija en el foreplay. El anunciador toma el micrófono e invita a las celebridades a compartir el escenario. Suben al ring los famosos - ex boxeadores, actrices, políticos- y la gente que se inviste performativamente de la fama de los peleadores. La prensa toma nota, toma fotos, constantemente irrumpe en el acto y es desalojada.

15 Entrevista personal realizada por Hortensia Moreno, en la Universidad Autónoma Metropolitana, plantel Xochimilco.

16 Obviamente, la mímica del boxeo es reproducida de manera intensa por los cuerpos adolescentes y juveniles de los muchachos de barrio, de quienes reclaman para sí la masculinidad ejemplar del boxeador. 
Por fin, el combate va a empezar. Todos los extraños se ven obligados a abandonar la pista. El anunciador, con sus papeles en la mano, grita al micrófono el nombre del campeón, que es calurosamente ovacionado por el respetable. Enuncia sus títulos, su peso, la división en que se ubica. Grita después el nombre del retador y lo mismo. “Pelearáaaaan...!” - e indica ahora la duración del encuentro-.

Mientras tanto, los boxeadores danzan. Ya se han quitado las batas, se han calzado los guantes, se han metido a la boca los protectores y exhiben sus cuerpos perfectos y sus calzoncillos más o menos elaborados. No hay mucho juego para la extravagancia en el boxeo; los extravagantes siempre son juzgados con desaprobación. En cuestión de segundos desaparecen todos los objetos del equipo de apoyo. En el cuadrilátero quedan solamente tres personas.

El cronómetro estructura el tiempo fino de los asaltos en la marca rigurosa del sonido de la campana. Durante el tiempo de cada round, sólo pueden estar en el ring los contendientes y el réferi. Las indumentarias tienen que ser cuidadosamente distintivas: es notable el contraste entre los pechos desnudos y la corrección de la camisa y la corbata del árbitro. La danza se complica. De ser un movimiento solitario se convierte en una frecuentación concertada, un cálculo del cuerpo del otro a partir del alcance del brazo o la precisión del tranco. Nadie está más concentrado en el cuerpo de otro que el boxeador a punto de conectar un golpe.

El cuerpo rigurosamente preparado durante meses, años, décadas. El cuerpo superpuesto a todos los cuerpos que en el cuadrilátero han sido. El cuerpo que hace sombra frente a su espejo. El espejo de ese cuerpo, de pronto indistinguible del cuerpo del otro. El cuerpo trenzado en el clinch. El cuerpo castigado al recibir el primer golpe y al escuchar, como en sueños, la reacción de la multitud enardecida, lentamente preparada, predispuesta, activa y feroz. Cada golpe-acontecimiento auto-referencial, performativo, único e irrepetible. Acto puro, acto desnudo y sin embargo anclado en la maraña de los signos. Signo y referente de sí mismo. Representación ritual, ceremonia colectiva. Creación y destrucción simultánea de corporalidades en el esfuerzo por encontrar el sentido de la vida.

El sentido de la vida del boxeador, el sentido del grupo cerrado del equipo de apoyo o de la familia; o bien del grupo abierto del barrio, de la nación o la humanidad. El cuerpo del boxeador se entrega al público sediento de acción. El dictamen escrupuloso de los jueces, el abucheo de la afición, la advertencia de las manos del réferi que lleva la cuenta implacable de los segundos fuera (de ese tiempo suspendido durante el cual el peleador se sume en una presencia ausente, en una conciencia turbia). El cuerpo del vencedor y el cuerpo del vencido son uno solo; el cuerpo se cubre de gloria en el combate: el rostro congestionado, los brazos adoloridos, el olor del sudor mezclado con la sangre que mana de las heridas y los orificios. 


\section{El cuerpo de la boxeadora}

El marco de normas y valores donde se desenvuelve el cuerpo de la boxeadora persiste en su hipermasculinidad. Las estrategias que el campo social del boxeo debe desarrollar para que las mujeres suban al cuadrilátero, incluyen un dispositivo que a la vez niega y afirma su principal enunciado: el de que se trata de una actividad cuyo fin principal es la producción de la hombría. El cuerpo de la boxeadora se desenvuelve en el mismo contexto simbólico, pero está marcado por una característica diferencial que le da al segundo el fundamento de su consistencia semiótica. ${ }^{17}$

En principio, el fenómeno es estrictamente discursivo-lingüístico: se trata de un resorte de significación mediante el cual queda marcado el cuerpo del Otro para establecer la representación del Uno. El cuerpo del boxeador, en tanto dispositivo significante, se refiere al cuerpo de la boxeadora como el elemento marcado. La marca funciona como signo de reconocimiento, es decir, como "operación cognoscitiva por la que un sujeto establece una relación de identidad entre dos elementos, de los cuales uno está presente y el otro ausente" (Greimas y Courtés 253-254). ${ }^{18}$ La oposición "marcado/no marcado" se emplea para distinguir dos elementos de significación "según que estén caracterizados por la presencia o la ausencia de un rasgo distintivo" (Greimas y Courtés 332). En los procesos de identidad, ciertos rasgos distintivos se constituyen en "marcas" cuando señalan a un sujeto como "otredad".

De manera paradójica, aquí el término no-marcado (el cuerpo del boxeador), se constituye al mismo tiempo como un lugar normativo - carente de atributos - y como la encarnación del mandato cultural e institucional ante el cual los cuerpos no entrenados de los varones comunes y corrientes figurarían como excluidos. No obstante, la magia performativa del boxeo permite a los cuerpos no entrenados de los varones compartir con el atleta la condición del "hombre" como universal, pero sólo en la medida en que contiene la exclusión del otro concreto (la mujer) que encarna su exterior constitutivo.

Las marcas por excelencia de la otredad identitaria señalan performativamente a los cuerpos que proporcionan el marco de inteligibilidad de quienes se postulan como sujetos en sentido pleno. Las oposiciones funcionan al contrastar ciertos rasgos "biológicos" como

17 He profundizado sobre la situación de las mujeres en el campo social del boxeo en Moreno, "Mujeres"; "Boxeo, peligro, masculinidad"; Orden discursivo; "La noción"; "El boxeo"; "Boxeuses à Mexico"; "Women boxers"; "Género, nacionalismo" y "Capital social".

18 "Esta discusión general de los límites del espacio y del tiempo implica otra serie de equivalencias metafóricas fundamentales [...] normal/anormal::temporal/intemporal::categorías bien delimitadas/categorías ambiguas::central/marginal::profano/sagrado" (Leach 47). 
indicadores "naturales" de diferencia. De esta forma, se construyen oposiciones donde, por ejemplo, el color de la piel se convierte en un marcador que permite, a quienes se presentan como "blancos", representar su identidad como una ausencia de atributos. De tal modo que es la otredad y sólo la otredad la que está marcada, mientras que la ausencia de marca se postula como el principio normativo de la oposición. Lo que se juega aquí es "un régimen disciplinario que genera, forma y construye discursivamente al sujeto"; se trata de modelos de discurso normativos e idealizados que producen, o traen al ser, a los propios sujetos que supuestamente demarcan (Ehlers 17-18).

Un límite separa dos zonas del espacio-tiempo social normales, temporales, bien delimitadas, centrales, profanas; pero los marcadores espaciales y temporales que realmente sirven de límites son también anormales, intemporales, ambiguos, marginales, sagrados [...]. Siempre que distinguimos categorías dentro de un campo unificado, espacial o temporal, lo que importa son los límites; concentramos nuestra atención en las diferencias, no en las semejanzas, y esto nos hace creer que los marcadores de tales límites son de valor especial, "sagrado", "tabú" [...]. El cruce de fronteras y umbrales siempre se rodea de ritual; también, por lo tanto, el cambio de un estatus social a otro (Leach 48). ${ }^{19}$

¿Qué hace el cuerpo de la boxeadora? Por una parte, repite cada uno de los gestos, cada una de las acciones que constituyen el gran ritual. Pero la repetición está signada por una diferencia que la sitúa en un espacio de liminalidad. Está atravesando un umbral y está a punto de adscribirse de manera simbólica a un estatuto que le está vedado. Su condición excepcional la sitúa entre aquellas figuras que Françoise Héritier-Augé ("Mujeres ancianas") caracteriza como "mujeres con corazón de hombre": atraviesa las fronteras femenino-masculino y al hacerlo revela la índole porosa y flexible de estas fronteras.

No obstante, el campo restablece sus reglas y recupera performativamente la distinción: las boxeadoras, cuerpos activos en el campo deportivo, son también danzantes y representantes; pero su signo es el de la feminidad enfatizada: por más rudas y fuertes que puedan aparecer en el escenario del ring, su apuesta se deslizará hacia la reivindicación de la delicadeza, la gracia, los buenos modales, el cuidado indumentario y la discreción. Entre los cuerpos de las deportistas, quizá no haya cuerpo más femenino que el cuerpo de la boxeadora.

19 Cursivas en el original. 


\section{Conclusiones}

En la medida en que los deportes se utilizan como expresión de la "naturaleza masculina" - como un arreglo diseñado para que los varones manifiesten cualidades masculinas-, tienen una función doble: por un lado, representar, poner en acto, servir como escenario para el performance de la "obvia" diferencia biológica - la cual se traduce irremediablemente en la inferioridad corporal de las mujeres-, y por el otro aportar el marco social que permite el desarrollo de dos culturas complementarias y paralelas que anclan los procesos de diferenciación sexual en usos diferenciales del cuerpo y la actividad física. Tales culturas crean las condiciones para la producción material de cuerpos que cultivan y realzan la diferencia corporal como destino. ${ }^{20}$

Dicho postulado de "naturaleza" oculta, por un lado, los mecanismos y tecnologías que permiten a una persona en particular convertirse en la portadora de una corporalidad atlética: iniciación oportuna, adecuación a la disciplina, entrenamiento riguroso, alimentación óptima, más todos los factores - sociales, políticos, económicos, geográficos, ecológicos, familiares, subjetivos, comunicativos- que sostienen esa conversión. ${ }^{21}$ Por el otro lado, oculta también la condición contingente de la corporalidad humana, su fragilidad inherente, el hecho de que todo cuerpo está sujeto a procesos de renovación y deterioro que son inevitables (nacer, crecer, enfermar, sanar, deprimirse, alegrarse, engordar, adelgazar, agotarse, recuperarse, envejecer, morir, etc.); así como a sucesos accidentales sobre los que no tenemos ningún control (choques, intoxicaciones, caídas, estallidos, cortaduras, colisiones, sismos, incendios, tropiezos, ataques, asaltos, envenenamientos). La vida está llena de percances que inciden de manera sustantiva en el cuerpo y van configurando sus alcances, sus capacidades, sus potencialidades.

\section{Referencias}

Anasi, Robert. The Gloves: A Boxing Chronicle. Nueva York: North Point Press, 2002. Austin, John. Cómo hacer cosas con palabras. Buenos Aires: Paidós, 1971. Benveniste, Émile. "La filosofía analítica y el lenguaje". Problemas de lingüistica general. México: Siglo XXI, 1976, pp. 188-197.

20 "Como consecuencia de este entrenamiento temprano en los deportes, los individuos pueden acarrear a lo largo de la vida un marco de disposición y respuesta, un sistema de referencia que aporta evidencia, quizá la evidencia, de que poseemos cierta naturaleza" (Goffman 322). Cursivas en el original.

${ }^{21}$ En otra parte (Moreno, "La invención") he discutido la invención del cuerpo atlético. 
Bourdieu, Pierre. ¿Qué significa hablar?: Economía de los intercambios lingüísticos. Madrid: Akal Ediciones, 1999.

Bourdieu, Pierre. Language E Symbolic Power. Ed. John B. Thompson. Cambridge: Harvard University Press, 1991.

Bourdieu, Pierre. “¿Cómo se puede ser deportista?” Sociología y cultura. México: Conaculta/Grijalbo, 1990, pp. 193-213.

Bourdieu, Pierre. "Sport and Social Class". Social Science Information, vol. 17, núm. 6, 1978, pp. 819-840.

Burgos Díaz, Elvira. Qué cuenta como una vida: La pregunta por la libertad en Judith Butler. Madrid: A. Machado Libros, 2008.

Butler, Judith. "Afterword". The Scandal of Speaking Body: Don Juan with J. L. Austin, or Seduction in Two Languages, Shoshana Felman. Stanford: The Stanford University Press, 2003.

Butler, Judith. Cuerpos que importan. Sobre los limites materiales y discursivos del "sexo". Buenos Aires: Paidós, 2002.

Camacho Quintos, Patricia. Danza y box: bálsamo y herida. México: Instituto Nacional de Bellas Artes, 2007.

De Garis, Laurence. "Be a Buddy to Your Body': Male Identity, Aggression, and Intimacy in a Boxing Gym". Masculinities, Gender Relations and Sport, Jim McKay, et al. Thousand Oaks, Londres y Nueva Delhi: Sage Publications Inc., 2000, pp. 87-107.

Demaria, Cristina. "The Performative Body of Marina Abramović Rerelating (in) Time and Space”. European Journal of Women's Studies, vol. 11, núm. 3, 2004, pp. 295-307.

Downing, Karen. 2010. “The Gentleman Boxer: Boxing, Manners, and Masculinity in Eighteenth-Century England". Men and Masculinities, vol. 12, núm. 3, pp. 1-25.

Ehlers, Nadine. Racial Imperatives: Discipline, Performativity, and Struggles against Subjection. Bloomington e Indianapolis: Indiana University Press, 2012.

Elias, Norbert. "La génesis del deporte como problema sociológico". Deporte y ocio en el proceso de la civilización, Norbert Elias y Eric Dunning. México: Fondo de Cultura Económica, 1995, pp. 183-211.

Felman, Shoshana. The Scandal of Speaking Body: Don Juan with J. L. Austin, or Seduction in Two Languages. Stanford: The Stanford University Press, 2003.

Godínez, Gloria. Conversación electrónica con Hortensia Moreno. 8 de marzo de 2018. Transcripción de mensaje de texto.

Goffman, Erving. "The Arrangement between the Sexes". Theory and Society, vol. 4, núm. 3, 1977, pp. 301-331.

Greimas, Algirdas, y Joseph Courtés. Semiótica: diccionario razonado de la teoría del lenguaje. Madrid: Gredos, 1982. 
Hargreaves, Jennifer. Sporting Females: Critical Issues in the History and Sociology of Women's Sports. Londres y Nueva York: Routledge, 1994.

Hauser, Thomas. The Black Lights: Inside the World of Professional Boxing. Fayetteville: The University of Arkansas Press, 2000.

Héritier-Augé, Françoise. "Mujeres ancianas, mujeres de corazón de hombre, mujeres de peso". Fragmentos para una historia del cuerpo humano. Comps. Michel Feher, Ramona Naddaf y Nadia Tazi, tomo 3. Madrid: Taurus, 1990, pp. 280-298.

Hollywood, Amy. "Performativity, Citationality, Ritualization". Bodily Citations: Religion and Judith Butler. Comps. Ellen T. Armour y Susan M. St. Ville. Nueva York: Columbia University Press, 2006, pp. 251-266.

Lafferty, Yvonne, y Jim McKay. 'Suffragettes in Satin Shorts'? Gender and Competitive Boxing". Qualitative Sociology, vol. 27, núm. 3, 2004, pp. 249-276.

Laqueur, Thomas. La construcción del sexo. Cuerpo y género desde los griegos hasta Freud. Madrid: Ediciones Cátedra/Universitat de València/Instituto de la Mujer, 1994.

Leach, Edmund. Cultura y comunicación. La lógica de la conexión de los símbolos. Madrid: Siglo XXI, 1989.

Markula, Pirkko. "Body-Movement-Change: Dance as Performative Qualitative Research". Journal of Sport E Social Issues, vol. 30, núm. 4, 2006, pp. 353-363.

Mier, Raymundo. Entrevista personal con Hortensia MoreNúm. 13 de enero de 2006. Transcripción.

Moreno, Hortensia y César Torres. "Performatividad". Conceptos clave en los estudios de género. Coord. Hortensia Moreno y Eva Alcántara, volumen II. México: Centro de Investigaciones y Estudios de Género de la UNAM, en prensa.

Moreno, Hortensia. "La noción de capital social en el estudio del boxeo femenil en la Ciudad de México”. GénEros, vol. 22, núm. 17, 2015, pp. 51-74.

Moreno, Hortensia. "Women Boxers and Nationalism in Mexico". Sports and Nationalism in Latin/o America. Eds. Héctor Fernández L'Hoeste, et al. New York: Palgrave Macmillan, 2015, pp. 181-200.

Moreno, Hortensia. “Género, nacionalismo y boxeo". Identidad imaginaria: sexo, género y deseo. Coord. Estela Serret. México: Universidad Autónoma Metropolitana-Azcapotzalco, 2015, pp. 255-291.

Moreno, Hortensia. "La invención del cuerpo atlético". AIBR. Revista de Antropología Iberoamericana, vol. 8, núm. 1, 2013. pp. 49-82.

Moreno, Hortensia. "Boxeuses à Mexico: Corps, violence et genre”. Problemes d'Amérique Latine, núm. 84, 2012, pp. 95-112.

Moreno, Hortensia. Orden discursivo y tecnologías de género en el boxeo. México: Inmujeres, 2011. 
Moreno, Hortensia. "La noción de 'tecnologías de género' como herramienta conceptual en el estudio del deporte", Punto Género, núm. 1, 2011, pp. 41-62.

Moreno, Hortensia. "El boxeo como tecnología de la masculinidad". La ventana. Revista de estudios de género, vol. IV, núm. 33, 2011, pp. 152-196.

Moreno, Hortensia. “Boxeo, peligro, masculinidad”. Revista de Investigación Social, año v, núm. 8, 2009, pp. 41-59.

Moreno, Hortensia. "Mujeres en el cuadrilátero: la dialéctica del 'fuera de lugar". Los contornos del alma y los límites del cuerpo: género, corporalidad y subjetivación. Coord. Rodrigo Parrini Roses. México, Programa Universitario de Estudios de Género de la UNAM, 2007, pp. 79-99.

Oates, Joyce Carol. 2002. On Boxing. Nueva York: Ecco (Harper Collins).

Palma Hernández, Erendira. "Un boxeador necesita ser un buen bailarín, dice el entrenador cubano Miguel Baro”. La Jornada, 18 de mayo de 2013, p. A15, en línea. Consultado el 18 de enero de 2018.

Pilgrim, Anita Naoko. "Performance and the Performative". Body E Society, vol. 7, núm. 4, 2001, pp. 87-96.

Prieto Stambaugh, Antonio. "En torno a los estudios del performance, la teatralidad y más". Performancelogía, 2002, en línea. Consultado el 28 de enero de 2018.

Prieto Stambaugh, Antonio. “iLucha libre! Actuaciones de teatralidad y performance”. Actualidad de las artes escénicas. Perspectiva latinoamericana. Comp. Domingo Adame. Xalapa: Universidad Veracruzana, 2009, pp. 116-143.

Salomón, Alfredo, director. Round en la sombra. México: Santas Producciones / Consejo Nacional para la Cultura y las Artes / Fondo Nacional para la Cultura y las Artes, 2007.

Schechner, Richard. Performance Studies: An Introduction. Londres y Nueva York: Routledge, 2002.

Scott, Susie. "How to Look Good (Nearly) Naked: The Performative Regulation of the Swimmer's Body". Body \& Society, vol. 16, núm. 2, 2010, pp. 143-168.

Slaughter, Stephany y Hortensia Moreno, coords. Representación y fronteras: el performance en los límites del género. México: Programa Universitario de Estudios de Género de la UnAM / Fondo de Desarrollo de las Naciones Unidas para la Mujer, UNIFEM, 2009.

Serret, Estela. Identidad femenina y proyecto ético. México: Miguel Ángel Porrúa / Programa Universitario de Estudios de Género de la UNAM / Universidad Autónoma Metropolitana Azcapotzalco, 2002.

Turner, Victor. The Anthropology of Performance. Nueva York: PAJ Publications, 1988.

Vigarello, Georges. "Ejercitarse, jugar". Historia del cuerpo: del Renacimiento a la Ilustración. Alain Corbin, et al. vol. 1. Madrid: Taurus, 2005, pp. 229-292. 
INVESTIGACIÓNTEATRAL

Revista de artes escénicas y performatividad

Vol. 9, Núm. 13

abril-septiembre 2018
El cuerpo del/la boxeador/a:

danza y representación

Hortensia Moreno

Vigarello, Georges. Historia de la belleza. El cuerpo y el arte de embellecer desde el Renacimiento hasta nuestros días. Buenos Aires: Nueva Visión, 2005.

Wacquant, Loïc. "The Social Logic of Boxing in Black Chicago: Toward a Sociology of Pugilism". Sociology of Sport Journal, vol. 9, 1992, pp. 221-254.

Woodward, Kath. Boxing, Masculinity and Identity: The "I" of the Tiger. Londres y Nueva York: Routledge, 2007.

Yébenes Escardó, Zenia. 2015. "Performatividad, prácticas corporales y procesos de subjetivación”. Diario de campo, núms. 6-7, 2015, pp. 70-74.

\section{Ficha técnica de Round en la sombra (video)}

\begin{tabular}{|l|}
\hline País: México. \\
\hline Año: 2007. \\
\hline Duración: 12 minutos 23 segundos. \\
\hline Dirección y postproducción: Alfredo Salomón. \\
\hline Producción: Elsa Castillo. \\
\hline Fotografía y edición: Andrés Castañeda. \\
\hline Sonido y música: Alejandro Arce. \\
\hline Asistente de foto: Alejandro Coronado. \\
\hline Asistente de producción: Gabriela Loaria. \\
\hline Voz en off: Fidel Romero. \\
\hline $\begin{array}{l}\text { Actuación: bailarín, Gilberto González; boxeador, Dante Jardón; alter ego, Ricardo “Fini- } \\
\text { to” López; réferi, Enrique Morales; modelo, Viviana Bravo. }\end{array}$ \\
\hline $\begin{array}{l}\text { Maquillaje proestético: Jorge Díaz y Jessica González; maquillaje: Ángeles Luna; ilumina- } \\
\text { dor: Jesús Fuentes (Canal 22). }\end{array}$ \\
\hline Asistente de iluminación: Gabriel González y Porfirio Galicia \\
\hline Responsable de audio: Francisco Puga \\
\hline Montaje: Francisco Borgia y Julio Velázquez. \\
\hline Video completo en: https://vimeo.com/234105 [consultado el 3 de junio de 2017]. \\
\hline
\end{tabular}




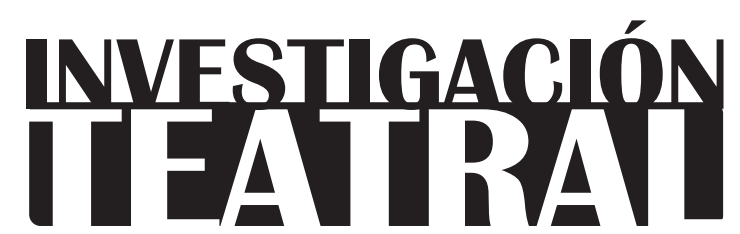

Revista de artes escénicas y performatividad

Vol. 9, Núm. 13

abril-septiembre 2018

Segunda época

ISSN impreso: 1665-8728

ISSN electrónico: 2594-0953

Universidad Veracruzana

\title{
La labor afectiva del duelo: ofrendas, pérdidas y desapariciones en Guerrero
}

\author{
Anne W. Johnson*
}

\footnotetext{
* Departamento de Ciencias Sociales y Políticas, Universidad Iberoamericana, México.

e-mail:anne.johnson@ibero.mx
}

Recibido: 14 de septiembre de 2017

Aceptado: 31 de enero de 2018 
INVESTIGACIÓNTEATRAL

Revista de artes escénicas y performatividad

Vol. 9, Núm. 13

abril-septiembre 2018
La labor afectiva del duelo: ofrendas,

pérdidas y desapariciones en Guerrero

Anne W. Johnson

\title{
La labor afectiva del duelo: ofrendas, pérdidas y desapariciones en Guerrero
}

\section{Resumen}

En este ensayo intento dar pistas para comprender la labor afectiva del duelo en dos contextos. Primero, retomo la construcción de las "ofrendas nuevas" en Teloloapan, Guerrero, como una expresión de luto y manera de manejar la pérdida de un ser querido. A continuación volteo la mirada a la emergencia del movimiento social alrededor de la desaparición forzada de cuarenta y tres normalistas en Iguala, Guerrero, expresión de una violencia en la cual está implicado el Estado mexicano y que, a la vez que enmarca la acción política en la experiencia de dolor y pérdida, demuestra los límites del proceso de duelo. El análisis de ambos casos me permite reflexionar sobre el duelo como una labor afectiva que, en distintas situaciones, produce distintos efectos culturales, psicológicos, sociales y políticos.

Palabras clave: duelo, afecto, movimiento social, Guerrero, materialidad, memoria.

\section{The affective labor of grieving: ofrendas, loss and disappearance in Guerrero, Mexico.}

\begin{abstract}
In this essay, I try to understand the affective labor of grief in two contexts. First, I take up the construction of the "ofrendas nuevas" in Teloloapan, Guerrero as an expression of mourning and a means of managing the loss of a loved one. I then turn to the emergence of the social movement that has grown up around the forced disappearance of 43 teacher-training students in Iguala, Guerrero, an expression of state-complicit violence that demonstrates the limits of the grief process, as it simultaneously frames political action in the experience of pain and loss. The analysis of both cases allows me to reflect on grief as affective labor that produces distinct cultural, psychological, social and political effects.
\end{abstract}

Keywords: Grief, Affect, Social movements, Materiality, Memory, Guerrero, Mexico. 


\section{La labor afectiva del duelo: ofrendas, pérdidas y desapariciones en Guerrero}

\section{Introducción}

$\mathrm{E}$ n este ensayo intento dar pistas para comprender el duelo en dos contextos. Primero, retomo la construcción de las "ofrendas nuevas" en Teloloapan, Guerrero, como una expresión de luto y manera de manejar la pérdida de un ser querido. Más adelante volteo la mirada a la emergencia del movimiento social alrededor de la desaparición forzada de 43 normalistas en Iguala, en el mismo estado; expresión de una violencia en la cual está implicado el Estado y que, a la vez que enmarca la acción política en la experiencia de dolor y pérdida, demuestra los límites del proceso de duelo. El análisis de ambos casos me permite reflexionar sobre el duelo como una labor afectiva que produce distintos efectos culturales, psicológicos, sociales y políticos. ${ }^{1}$

Las ofrendas llenan el vacío que deja la ausencia del difunto con un conjunto de objetos prostéticos. Forman parte de un proceso de duelo que permite a los dolientes manejar sus experiencias de pérdida y salir adelante. Las acciones que emprenden las madres y padres de los desaparecidos de Ayotzinapa, por otra parte, giran alrededor del lema "nos faltan 43" y resaltan las ausencias que no se pueden resarcir a través del proceso psicológico "normal"

1 Agradezco enormemente a los participantes en el coloquio "Teatro y abandono", organizado por Rodrigo Parrini y Eduardo Bernal, y también a los participantes en el seminario "Memoria Colectiva" patrocinado por la Coordinación Nacional de Antropología del INAH. Sus comentarios sobre las inquietudes expresadas en este texto fueron invaluables. Por otra parte, fueron de gran ayuda los comentarios del dictaminador anónimo de este texto para aclarar varios conceptos y argumentos. 
del duelo, ya que apelan también a vacíos políticos y sociales. Concluyo este ensayo con una consideración de la relación entre duelo, materialidad y memoria, sugiriendo un replanteamiento de las posibilidades productivas de la melancolía.

\section{La muerte en Teloloapan}

El estudio de la construcción de las ofrendas nuevas en Teloloapan permite entrever cómo ciertas prácticas performativas implican la construcción de - y participación en - una malla de relaciones que involucran a otros humanos y objetos materiales. Me enfocaré en un conjunto de acciones que conmemora la muerte en Teloloapan, Guerrero, pueblo viejo de trasfondo nahua ubicado en la región norte del estado que, en voz de sus pobladores, "ya no" es una comunidad indígena.

La producción de "las ofrendas nuevas" vincula a teloloapenses vivos y muertos con objetos materiales en una malla de conocimientos, acciones y percepciones que les permiten moverse en un mundo precario. La ofrenda es, como veremos, un proceso más que un producto. Y en el centro de este proceso está el duelo. Espero mostrar cómo la creación de la ofrenda forma parte de una labor afectiva que moviliza personas, cosas y fuerzas, elementos duraderos y efímeros, como una manera de enfrentar la pérdida.

Cuando llegué al pueblo en agosto de 1999 para hacer trabajo de campo como parte de mi tesis de doctorado en antropología social, planeaba estudiar las representaciones colectivas de la Guerra de Independencia en la región norte del estado de Guerrero, concentrándome en la tradición de los Diablos de Teloloapan como parte de una poética historia local, construida ante la imposición de una historia y una identidad nacionales (ver Johnson, Diablos, insurgentes). Más o menos seguí con el proyecto original, pero como suele suceder (y como debe suceder), la "realidad" terminó transformando y ampliando mis temas de investigación.

Don Fidel de la Puente Fabián, encargado de la tradición de los Diablos, mascarero y mi interlocutor principal, murió repentinamente en marzo de 2000 a los setenta años; como consecuencia, el manejo de la muerte en el pueblo encontró un espacio dentro de mi trabajo. Las prácticas que envuelven este manejo se llevan a cabo en distintos momentos a partir del fallecimiento del sujeto, pero aquí me enfocaré en las "ofrendas nuevas", (aclarando que, como de algún modo me había convertido en miembro de la familia de Don Fidel, mi análisis de estos procesos no se puede separar del recuerdo corporal de haber participado en las labores que los sostenían). 


\section{La "ofrenda nueva"}

Cuánto alboroto. Cuando me muera, mejor envuélvanme en un petate, y échenme al hoyo Doña Gloria, prima de Don Fidel.

El primer año después de la muerte de una persona, se arma una ofrenda muy vistosa y compleja. Se llama la "ofrenda nueva" y no se repite con la misma espectacularidad en años posteriores. Una semana antes de la celebración de los Días de Muertos, se publica una lista de personas que han fallecido en el curso del año en el periódico local para que todo el público pueda visitar las ofrendas, evaluarlas y compararlas, además de acompañar a las familias en su proceso de luto. Después de las dos noches de visita a las ofrendas - el 31 de octubre para los difuntos chiquitos y el $1^{\circ}$ de noviembre para los difuntos grandes-, todas las familias llevan las flores de las ofrendas a las tumbas de sus familiares en el panteón, donde siguen compartiendo los alimentos entre ellos y con sus muertos.

Vale la pena ofrecer más detalles sobre el proceso de construcción de estas ofrendas (únicas, hasta donde sé, en Guerrero y en México), ya que es la labor afectiva y performativa involucrada en su producción lo que despliega un conjunto de fuerzas y objetos que les dan su poder y particularidad. Una de las características que distingue a la ofrenda teloloapense es el "cielo" de papel que cubre el techo y las paredes del cuarto o espacio donde se arma. Normalmente hay una imagen religiosa central de algún santo o acontecimiento bíblico, prestada a la familia por algún dueño o párroco, o en su caso dibujada o esculpida en escala humana o un poco más grande.

Para las difuntas, se coloca la imagen de una virgen, y para los difuntos hombres, un santo o una imagen de Cristo. La representación bíblica es acompañada por una imagen del fallecido - puede ser una fotografía u otra representación iconográfica-, así como por objetos que representan los gustos o actividades de la persona en vida, además de plantas, pilares, tierra, "llorones" (estatuas de yeso de niños llorando), flores y velas. Suele además colocarse una representación de la tumba del difunto, un soneto o poema en su honor y en ocasiones bordados en tela u otras artesanías. Recientemente, se han empezado a incorporar varios elementos multimediáticos como luces, sonido y videos o diapositivas proyectadas.

Muchas familias contratan a un ofrendero para crear este elaborado ensamblaje. Los gastos pueden llegar a ser enormes, igual que el tiempo invertido en la construcción. A veces la gente se refiere a la exhibición de las ofrendas como un "concurso," aunque no concluye en una premiación. Algunos ofrenderos son artesanos por oficio, mientras que otros son personas conocidas por su creatividad o bien por su vocación religiosa. 


\section{La ofrenda de Don Fidel}

Para construir la ofrenda se trabajó primero con el papel, cocinando una mezcla de engrudo para pegar cientos de pliegos y así crear el cielo; a continuación se le arrugó y se le ataron nudos para generar la textura necesaria y se pintó en azul de distintos tonos. Se decidió adoptar como imagen principal la de Cristo, Dimas y Gestas crucificados en El Calvario, usando como modelo un calendario que don Fidel tenía colgado en su cocina. Se pidieron prestadas las figuras de Dimas y Gestas a un vecino, pero el Cristo se elaboró con papel maché aprovechando los innumerables ejemplares de La Prensa que don Fidel había almacenado en su casa.

Se completó el escenario con armazones y otros materiales básicos: pintura, iluminación (la luz negra sobre colores fosforescentes se ha vuelto muy popular en los últimos años), rocas, agua y plantas. Después se colocaron los objetos relacionados con el difunto: fotografías, la tumba, el soneto, los bordados, las miniaturas y los objetos preferidos. Se puso una calaca o esqueleto de poliestireno pintado de amarillo fosforescente, y colgando de uno de sus brazos se colocó el morral de piel que solía usar el difunto con dos botellas de Coca-Cola de vidrio en su interior. A los pies de este personaje, un tanto espeluznante, se colocaron varios diablos en miniatura y frente a él un maniquí también vestido de diablo. Finalmente se complementó la ofrenda con flores, velas y pan, cuyo número aumentaba conforme llegaban los espectadores. Un grupo de jóvenes vestidos de diablos hacía guardia afuera de la ofrenda, cada uno con un ramo de flores. La familia ofreció ponche caliente y pan recién horneado a los concurrentes.

\section{Ofrenda y memoria}

La creación de la ofrenda forma parte del proceso de manejo de la aflicción. Las ofrendas son sitios de memoria (ver Nora, "Between Memory") que se conforman conjugando varias cosas. Primero se necesita un espacio dentro del hogar del difunto o sus parientes; segundo, la acumulación y arreglo de objetos materiales: fotografías, figuras religiosas, textos, medios visuales y auditivos, comida, flores, etcétera; tercero, los elementos teatrales como el cielo de papel o tela, las luces, pintura, bocinas, soportes estructurales y otros elementos que forman un telón de fondo para los objetos exhibidos (y coadyuvan a convertir un espacio doméstico en un lieux de memoire más íntimo); y finalmente, los cuerpos de quienes crean la ofrenda mediante la transformación del espacio, cuyos recuerdos confieren significado a todo lo demás. Podría considerarse aún un quinto elemento fundamental, más ausencia que presencia: es percibido como el fantasma del difunto o simplemente su ausencia; la fuerza del deseo ocasionado por la pérdida es lo que impulsa la ofrenda. 
"El espacio contiene el tiempo comprimido", escribió Bachelard, "para eso es el espacio" (La Poética, 31). Crear una ofrenda es una manera de movilizar el espacio doméstico, convertir un cuarto en un contenedor de tiempo comprimido, rellenarlo con dispositivos mnemónicos diseñados para representar los elementos más sobresalientes de la identidad del difunto (según su familia) y evocar los recuerdos del público.

Los objetos de la ofrenda cumplen diversas funciones. Por un lado están aquellos que intentan establecer algún tipo de intercambio: comida, velas, flores, etcétera. En segundo lugar, los que tienen una función mimética (copias del difunto cuyo poder mágico se deriva de su semejanza con él o ella), como pueden ser las efigies, fotografías, videos, figuras en tres dimensiones o cualquier otra representación del difunto. Finalmente, podemos considerar ciertos accesorios cuyo poder se deriva de la segunda ley de la magia simpática -el contagio-, es decir, objetos que estuvieron en contacto directo con el difunto (como sus ropas o accesorios) y absorbieron de ese modo su magia. Los últimos dos tipos sustituyen al sujeto ausente de uno u otro modo.

También suele haber copias indexicales en pequeña escala de las actividades o lugares asociados con el difunto. Se trata de miniaturas en las que, siguiendo a Bachelard, "los valores se condensan y se enriquecen [...]; uno tiene que ir más allá de la lógica para experimentar qué es grande y qué es pequeño" (138). La reducción en escala nos permite comprender, captar y consumir visualmente lo representado, reduciendo "el espacio del sujeto y el espacio de lo social" (Stewart, On Longing 68), comprimiendo y materializando la historia vital del sujeto en un objeto diminuto que, a pesar de su tamaño, puede condensar detalles que hacen entrar al espectador dentro del objeto y dentro de sus propios recuerdos.

Según Serementakis, la memoria es "una práctica culturalmente mediada que se activa a través de acciones corpóreas y objetos semánticamente densos” (Serementakis, On Longing 9). Un objeto de ofrenda "semánticamente denso" se puede entender como una próstesis del sujeto, "un elemento foráneo que reconstruye lo que no se puede parar solo, al mismo tiempo sosteniendo y extendiendo a su anfitrión” (Wigley, en González "Autotopographies" 135). González denomina a este tipo de colección de objetos "autotopografías" o "museos del ser":

Existiendo en el contínuum de monumento y microcosmos, esta colección, este arreglo o almacenamiento de objetos simbólicamente significativos representa una identidad personal en relación a una red social más amplia de significados y funciones para anclar la imagen autoreflexiva del sujeto dentro de un cosmos local y terrenal. En la creación de una autotopografía - que no incluye toda la propiedad personal sino solamente aquellos objetos que significan una identidad "individual" - se hace 
una llamada al mundo material para presentar un mapa físico de memoria, historia y creencia. El objeto autobiográfico entonces se convierte en mecanismo prostético: una adición, un rastro y un sustituto por los aspectos intangibles de deseo, identificación y relaciones sociales (134).

En este sentido, los objetos de una ofrenda coleccionados por los miembros de la familia y no por el sujeto mismo, podrían entenderse como biotopografías. Al igual que sucede en cualquier otra historia, la historia de vida representada en la ofrenda está llena de silencios (ver Trouillot, Silencing the Past). Nunca "terminada," la ofrenda representa entonces la percepción parcial y muchas veces nostálgica de los otros acerca de un sujeto; crea un espacio tanto para recordar como para olvidar, forjando "un vínculo metonímico con eventos pasados y personas ausentes" (González, "Autotopographies" 134). Las brechas en la ofrenda exigen la participación corpórea para completar el circuito mnemónico. Como escribe nuevamente Serementakis,

El paisaje sensorial y sus objetos-dotados-de-significado conllevan una sedimentación emocional e histórica que puede provocar y encender gestos, discursos y acciones; acciones que abren la estratigrafía de estos objetos. Así, el entorno de la cultura material no es ni estable ni fijo, sino inherentemente transitivo, exigiendo conexión y completitud por el público ("The Memory" 7).

Pero el otro silencio, más allá de lo que se excluye en el objeto-narrativa, es el de la pérdida. La ausencia del difunto queda subrayada precisamente por la presencia de tantos objetos materiales, así como por el exceso de memoria que éstos suelen invocar. Es en la brecha ominosa entre la materialidad excesiva de la ofrenda y la ausencia palpable del ser querido que se producen el deseo y la memoria: "La memoria es un índice de pérdida" (Davis y Stern, "Introduction to Special" 4), y es dicha pérdida la que anima la ofrenda.

La ausencia se combate, no obstante, mediante la representación cósmica (producto de la fe católica) que permite creer a los vivos que los muertos todavía tienen su lugar en el universo, aunque ya no en la tierra sino en el paraíso. Se recrea así un imaginario que permite un manejo psicológico de la pérdida. Se establece la sobrevivencia del ser desvanecido en el escenario mental estructurado por los recuerdos que evocan los elementos simbólicos de la ofrenda, pero también en el teatro externo de la misma ofrenda, que representa una visión del más allá donde los difuntos están bien acompañados por Jesucristo, la Virgen María y los santos. 


\section{Muerte, ofrendas y violencia}

Estudiar las ofrendas nuevas ha sido una manera de mantenerme informada sobre la cuestión de la mortalidad en Teloloapan: ¿quiénes mueren y de qué? Hace algún tiempo, se construían ofrendas para las personas que morían "de viejo", por enfermedad, accidentes automovilísticos o riñas personales que se tornaban violentas a causa del alcohol. En los últimos años, sin embargo, ha aumentado la cantidad de muertes relacionadas con la violencia vinculada al tráfico de drogas en la región (resalta un número desproporcionado de ofrendas para policías, choferes y taxistas).

Además, gracias a la confluencia de objetos mnemónicos hechos paisajes biotopográficos por los familiares y acompañantes de los difuntos, las conversaciones que tienen lugar en el contexto de las ofrendas se han vuelto una de las pocas formas de comunicación abierta sobre la experiencia de la violencia actual, dado el temor que ésta genera en la población.

\section{El duelo como labor afectiva}

El duelo como proceso creativo nos lleva a reflexionar no solamente sobre su importancia como fenómeno que permite la sanación psicológica del individuo frente a la muerte de un ser querido, sino también sobre las posibilidades del duelo colectivo frente a pérdidas que son consecuencia de la violencia en todas sus expresiones. ¿Cómo pensar, por ejemplo, la experiencia del duelo de los familiares de los desaparecidos, situación que afecta cada vez más a la sociedad mexicana contemporánea?

Si un elemento fundamental de la ofrenda en Teloloapan es el juego entre la presencia y ausencia simultáneas del cuerpo del difunto, ¿cómo procede el proceso de duelo cuando no hay cuerpo? ¿Es posible "cerrar" el proceso? ¿Es necesario? ¿Es deseable? O por otro lado, ¿es posible mantener abierta la crítica y el potencial para la transformación de la realidad, apegándose al lema "vivos los queremos"? Voy a argumentar que, en todo caso, el duelo es performativo: hace algo más allá de tranquilizar la tristeza y rabia del doliente. Despliega las posibilidades del movimiento, del acompañamiento y de la creatividad para construir nuevas relaciones y transformar las viejas, abriendo un espacio para imaginar el futuro con base en la memoria del pasado. 


\section{De duelo y melancolía: Nos faltan 43}

\section{Militancia, claro, entonces, pero duelo también: duelo y militancia. Douglas Crimp, "Mourning and Militancy"}

Como señaló Freud ya hace muchos años en "Duelo y melancolía" (1917), el proceso del duelo suele permitir que una persona que ha sufrido la pérdida de un ser querido en un momento dado, logre superar sus sentimientos de tristeza y enojo con la finalidad de "salir adelante", a pesar del vacío que deja la ruptura de una relación humana, - momentos en los que se evidencia la vulnerabilidad del sujeto ante el otro, cuya ausencia amenaza la integridad del "yo" (Butler, Precarious Life 31) - . La ofrenda nueva llena este vacío por lo menos parcialmente, con objetos e imágenes mnemónicas que sustituyen a la persona ausente. En los rituales de la muerte se reafirman además los lazos sociales entre el sobreviviente y sus semejantes.

No obstante, hay duelos que por distintas razones no terminan con la superación del dolor sino que continúan durante un periodo indeterminado. Freud apela al afecto de la melancolía para ubicar estos casos, que concibe como procesos patológicos de duelo que no siguen su curso "normal", aun cuando admite que los melancólicos poseen "una visión más aguda para la verdad que otras personas que no son melancólicos". Pero con Eng y Vazanjian habrá que preguntarnos "por qué un hombre tiene que estar enfermo antes de poder acceder a una verdad de este tipo" ("Introduction: Mourning Remains" 23).

A este respecto, en muchos casos llama la atención lo que ocurre no solamente con el proceso psíquico individual, sino también con los procesos sociales de duelo. Los sujetos colectivos podrían tener dificultades con los procesos "normales" de manejo de pérdida en ciertas situaciones, sobre todo cuando la muerte ocurre de manera repentina o por violencia. En el caso de la desaparición y el desconocimiento del paradero de la víctima o su cuerpo, estos procesos se tornan aún más complicados y la prolongación es particularmente evidente cuando no hay acceso a la justicia o reconciliación con la muerte. En contraste con el punto de vista de Freud, propongo explorar cómo esta dilatación de las expresiones de duelo puede funcionar como una labor afectiva con efectos sociales y políticos, una estrategia para exigir justicia - la verdadera ausencia - más que una reacción patológica a la pérdida. ${ }^{2}$

2 El duelo crítico y prolongado de las madres y los padres de familia de los normalistas desaparecidos no debe confundirse con la melancolía poética expresada por muchos escritores mexicanos, descrita por Roger Bartra hace muchos años como la añoranza de un "Edén subvertido", de un pasado utópico, campesino y comunitario destruido por el avance inexorable de la modernidad (Bartra, La jaula 31). Al contrario, lejos 
INVESTIGACIÓNTEATRAL

Revista de artes escénicas y performatividad

Vol. 9, Núm. 13

abril-septiembre 2018
La labor afectiva del duelo: ofrendas, pérdidas y desapariciones en Guerrero

Anne W. Johnson

\section{Nuestros hijos con vida}

Después de la noche del 26 de septiembre de 2014, cuando en Iguala, Guerrero (pequeña ciudad que se encuentra a unos sesenta kilómetros de Teloloapan), fueron forzadamente desaparecidos los estudiantes de un grupo de la Normal Rural "Raúl Burgos" de Ayotzinapa, la protesta social y política en contra de la inseguridad y corrupción en el narco-Estado mexicano llegó a configurarse alrededor de este vacío explícito: "nos faltan 43". El lema "Vivos se los llevaron, vivos los queremos", llamada de muchos movimientos de familiares de desaparecidos, anuncia la negación absoluta de la muerte de los normalistas, pero también un rechazo rotundo a la "versión histórica" de los acontecimientos que ofreció el Gobierno Federal mexicano.

Esta resistencia ante la versión "oficial" de los acontecimientos, según la cual los normalistas fueron asesinados y quemados en el basurero de Cocula por miembros del grupo delictivo Guerreros Unidos, en colusión con las autoridades municipales de Iguala, podría ser freudianamente comprendida como una manifestación de melancolía, una obstinada prolongación del duelo a pesar de "las evidencias" de las muertes y la supuesta ubicación de las cenizas de los estudiantes en bolsas de plástico arrojados en un río cercano al basurero. El apego a la búsqueda de sus hijos, el recordatorio constante de que "nos faltan 43", las marchas continuas con las fotos escolares de los estudiantes desaparecidos: ¿no señalan una especie de melancolía? ¿No evidencian aquella enfermedad definida por Samuel Johnson ya en el siglo XVIII como "una especie de locura, en la que la mente se mantiene fija en un solo objeto, un temperamento morboso, pensativo, inquieto"? (en Bowring, A Field Guide 15) ¿Se trata de uno de los casos ejemplares freudianos de duelo enfermizo? ¿Las madres y los padres de los normalistas son "Lloronas" modernas, obsesivamente gritando “Ay, mis hijos!” sin esperanza y sin cesar?

Tal interpretación convendría al Gobierno, cuya versión de lo que ocurrió aquella noche en Iguala intentó negar la complicidad del Estado ("no fue el Estado", aseveró en su rueda de prensa Jesús Murillo Karam, el entonces Procurador de Justicia) y clausurar el movimiento social que ya había crecido alrededor del caso. Si la búsqueda de los padres era un mero síntoma de melancolía, entonces parecería justificado pensar que lo que debieron haber hecho era volverse a llorar en sus tierras, pues ¿quién puede hacerle caso a la Llorona? Al Estado le conviene además pensar en los disidentes como Lloronas para que sean vistos como agentes de su propia desgracia: tal como la mujer de blanco es culpable de su

de un "fatalismo social" esencialista que los atraparía en el pasado y la tradición, estos actores marginados desde el punto de vista de la imposición de normatividades socioculturales, políticas y corpóreas, mantienen una apertura permanente frente al pasado, que les permite exigir un futuro distinto. 
dolor por haber matado a sus propios hijos, los miembros del movimiento son los responsables de las muertes de sus compañeros o parientes por ser pobres, por ser indígenas, por ser "revoltosos".

\section{"Fue el Estado": el duelo desafiante}

Pero el duelo, pensó una vez Walter Benjamin, es una forma de mantener abierta una relación crítica con el pasado en contra del historicismo (como el de aquella "versión histórica") que congela el pasado y no permite su cuestionamiento (en Eng y Kazanjian, "Introduction" 2). Eng y Kazanjian indagan en lo que ellos llaman "la política del duelo", que describen como "aquel proceso creativo que media una relación esperanzada o sin esperanzas entre la pérdida y la historia" (ibíd.). La "pérdida", según estos autores, incluye todo lo aprehendido "por los discursos y las prácticas del duelo, melancolía, nostalgia, trauma y depresión” (ibid.).

Para Benjamin y otros autores, el duelo es un afecto, una relación o una estructura de sentimiento bastante amplia, que no se limita a los desesperados llantos de una Llorona, sino que implica asimismo la labor creativa que emerge de él. No se orienta, por tanto, únicamente hacia el pasado, sino también al futuro en tanto que el acto de narrar la pérdida implica un impulso hacia adelante (13). En contraste con la concepción freudiana de la melancolía como un apego patológico a la pérdida, existen situaciones en las cuales el duelo tiene la posibilidad de convertir la melancolía - experimentada como emoción interna y pasiva - en un afecto capaz de orientar la acción colectiva. ${ }^{4}$

En el movimiento social que creció alrededor del caso Ayotzinapa, el duelo se convirtió en un conjunto de acciones: protesta, denuncia, búsqueda de fosas y cuerpos, narración de la pérdida, recordatorio, entre otras... Acaso las madres y los padres de los normalistas

${ }^{3}$ La leyenda de la Llorona es interesante por muchas razones, pero sobre todo por la posición social que le corresponde al personaje en el imaginario mexicano (en una de sus versiones), como amante, indígena y mujer. Es posible incluso ver en sus incesantes llantos una crítica al sistema colonialista y patriarcal que orilla a las mujeres a tomar decisiones impensables para sobrevivir. ¿El llanto de La Llorona también puede denunciar? El uso de la canción popular homónima, versionada por varios grupos que la utilizan para protestar también por la desaparición de los 43 normalistas, pareciera confirmar las posibilidades críticas de esta figura.

${ }^{4}$ Este tema, sobre todo en relación a las propuestas artísticas que emergen como reacción a la violencia y la pérdida en distintos contextos latinoamericanos, es ampliamente abordado en el libro Cuerpos sin duelo de Ileana Diéguez (2013). 
desaparecidos no se asemejan tanto a la Llorona - excepto en la repetición incesante del lamento provocado por el trauma-, como a Antígona, la heroína griega que rechazó la prohibición del Estado para enterrar el cuerpo de su hermano fallecido en la guerra civil y, como consecuencia, fue condenada a muerte. El grito “inos faltan 43 !" convierte el luto privado en duelo público al irrumpir en los espacios estatales y cívicos, reclamando justicia a un Estado que se deslinda de cualquier responsabilidad.

La labor de Antígona, como la de las madres y padres de Ayotzinapa, es un trabajo afectivo y político. La heroína trágica apelaba — por encima de la ley estatal que dividía a los ciudadanos de los no ciudadanos, o a los dignos de los indignos de un entierro rituala la ley humana que se traduce en el deber familiar respecto a los muertos y el derecho al duelo. Las madres y padres de los normalistas desaparecidos reclaman igualmente los derechos de sus hijos de gozar del estatus de ciudadanos, de ser reconocidos como sujetos (individuales, pero también colectivos) "llorables" — diría Judith Butler-, cuyas muertes, pero sobre todo cuyas vidas, deberían de valer (Butler, Precarious Life 34). Quizás la finalidad última del movimiento, más allá de enterrar dignamente a los desaparecidos, es que primero sean reconocidos como enterrables.

Como la labor afectiva de las ofrendas nuevas en Teloloapan, la labor del duelo emprendido por los participantes en el movimiento social "Nos faltan 43 " depende de una relación ambivalente entre la presencia y la ausencia, la movilización de vínculos emotivo-sociales, un ensamblaje particular de imágenes y objetos y un juego espacial entre movimiento y estasis. Pero estos elementos son empleados de manera distinta y con fines distintos.

\section{Imágenes y objetos melancólicos}

Los desaparecidos de Ayotzinapa tienen un estatus liminar: ni muertos ni vivos, ni presentes ni ausentes, ni cuerpo ni espíritu (Ovando, "La fuerza" 59). Los objetos materiales empleados como parte del movimiento social reflejan de alguna manera dicha ambigüedad. Las armas principales de las madres y padres son las imágenes de sus hijos desaparecidos, que van acompañadas por sus nombres. Tal como ocurre con las ofrendas nuevas, en este contexto la imagen es también memoria y presencia del individual perdido; se convierte en fetiche que actúa mediante la magia mimética de la fotografía para invocar lo que no está. ${ }^{5}$

Los retratos son de los rostros de los estudiantes y evidencian las distintas dinámicas que la cara puede tener: funciona como la "ventana del alma" y como la superficie que per-

\footnotetext{
${ }^{5}$ Según el escritor chileno Pablo Oyarzún, "no hay duelo sin imagen" (en Diéguez, Cuerpos sin duelo 204).
} 
mite reconocer a un sujeto, pero también como una máscara. "El rostro es la evidencia que hace posible la evidencia", decía Levinas (en Taussig, Defacement 224). En algunas de las marchas, los participantes literalmente se han puesto estas fotografías como máscaras, encarnando simbólicamente a los desaparecidos y haciéndolos copartícipes del movimiento, a la vez que materializan su identificación con los sujetos desaparecidos.

Tomadas una por una, cada imagen evoca la pérdida sufrida por una familia, la añoranza de encontrar vivo a un hijo con nombre propio o, en el peor de sus casos, sus restos identificados mediante alguna prueba de ADN. Como señala Taylor en relación con los desaparecidos de la guerra sucia en Argentina, la foto y el ADN "ofrecen radicalmente distintas pruebas de 'presencia, claro, cada uno visibilizando lo que es totalmente inaccesible al otro" (The Archive 176). Ambos funcionan como "evidencias", huellas de una persona perdida, de una relación rota. ${ }^{6}$

Mientras que algunas representaciones artísticas de los rostros de los estudiantes intentan nombrarlos e individualizarlos, las marchas y protestas no giran alrededor de la pérdida de un individuo, sino de cuarenta y tres (y más). El conjunto de imágenes, cuyo despliegue masivo difumina los detalles y las particularidades de cada rostro dada la semejanza estilística de las fotografías, impacta por el horror de imaginar la cantidad de personas simultáneamente desaparecidas. No son propiamente biotopografías, sino necrotopograf ías. ${ }^{7}$

Como en las ofrendas de Teloloapan, los procesos de duelo manifestados en el movimiento social por los cuarenta y tres están íntimamente entrelazados con la creación artística. En las instalaciones creativas que caracterizan al movimiento, el ensamblaje más común es una colección de 43 butacas vacías (a veces en cada butaca se pone una fotografía pegada que, desde luego, no llena la silla ni física ni afectivamente). No se trata nuevamente de la individuación de las víctimas mediante una ofrenda prostética personal, sino de la representación de un vacío colectivo, de un conjunto de ausencias donde debería haber presencias. Las sillas podrían compararse con los muebles que habitaban las casas abandonadas tras los desastres nucleares en Chernobyl o Fukshima, o las de los "pueblos fantasmas" abandona-

${ }^{6}$ Hasta la fecha, las pruebas de adn realizadas por un laboratorio en Alemania a 17 muestras, encontradas supuestamente en Río San Juan, solamente han confirmado la identidad de dos de los normalistas desaparecidos: Alexander Mora Venancio y Jhosivani Guerrero de la Cruz. Peritos del Grupo Interdisciplinario de Expertos Independientes (giei) contratados por la Comisión Interamericana de Derechos Humanos (cidh) desestimaron, sin embargo, la "versión histórica" sostenida por la Procuraduría General de la República (http://prensagieiayotzi.wix.com/giei-ayotzinapa\#!Ayotzinapa-Investigación-y-primeras-conclusiones/ cul3/55edc77cocf23dofeffdgco2/, consultado el 15 de enero del 2016).

${ }^{7}$ Las cifras oficiales cuentan por lo menos 26,ooo desaparecidos en todo el país hasta el día de hoy. De este registro, solamente el dos por ciento está relacionado con una averiguación previa, según datos del Registro Nacional de Personas Extraviadas o Desaparecidas (http://www.animalpolitico.com/2015/06/en-2015-once-personas-desaparecidas-cada-24-horas/, consultado el 15 de enero del 2016). 
dos por las víctimas de la narcoviolencia en Guerrero y otros estados de la República Mexicana, o con los objetos personales desechados en el camino por los migrantes que cruzan clandestinamente las fronteras mexicanas (ver Parrini, "La memoria"). Performativamente, las sillas vacías son "ruinas", parte de aquella clase de objetos que quedan como huellas de destrucción o abyección (Navarro-Yashin, "Affective Spaces" 5).

La lógica del "vivos se los llevaron, vivos los queremos", no obstante, hace que el duelo de los participantes se mezcle con la esperanza (ver Diéguez, Cuerpos sin duelo 33): las butacas podrían ser ocupadas una vez más. No se trata de ofrendas a los muertos para que éstos descansen en paz, sino de objetos mnemónicos que no quieren dejar descansar en paz a los culpables. A diferencia de la labor afectiva de las ofrendas nuevas en Teloloapan, el trabajo afectivo-político de este movimiento social no busca sanar heridas, sino mantenerlas abiertas. El movimiento es eficaz en la medida en que sigue siendo de alguna manera melancólico, para que el caso no se cierre y para que los fantasmas de los 43 sigan acechado a los vivos. Encontrar los cuerpos, identificarlos por nombre y enterrarlos sería matarlos de nuevo y para siempre. Ya no habría nada que exigir al Estado, excepto, quizás, un "Nunca más" que históricamente no ha sido un reclamo particularmente eficaz.

\section{Rutas, centros y márgenes}

Las marchas, como las procesiones funerarias en Teloloapan, trazan rutas de poder y marcan lugares significativos. Pero en lugar de la cartografía que une los puntos casa-iglesia-panteón, la marcha materializa el imaginario cartográfico de una nación hecha de centros y periferias, ligando los márgenes económicos, políticos y sociales con los centros de poder. Las muertes de migrantes en la frontera y de víctimas de la narcoviolencia en la periferia, que ocurren en los márgenes u orillas del Estado, son de suma importancia en tanto que - como argumentan Das y Poole- el Estado es "el sitio en el cual se instituyen mutuamente la biopolítica y la tanatopolítica [...] y [en tanto] que esta relación, que está en el corazón del estado moderno, es más visible en sus márgenes que en su centro" ("State and its" 25). Las marchas son una manera de visibilizar en el centro la violencia estatal que ocurre en la periferia, protestando por la vulnerabilidad de quienes tienen "vidas precarias" y por la distribución desigual del dolor y del luto (Butler, 2004); además de insistir ante las autoridades, por supuesto, que deben aceptar su culpabilidad institucional, pues "Sí fue el Estado".

${ }^{8}$ El choque discursivo entre "No fue el Estado" y "Sí fue el Estado" merece mucho más atención de la que es posible prestarle en este texto, sobre todo porque articula las tensiones entre diversas maneras y perspectivas para entender lo que significa "El Estado": por un lado, se percibe como institución cuasi-mágica que 
Ayotzinapa-Chilpancingo-Ciudad de México es una ruta crítica fundamental, pero también lo son las múltiples rutas de las marchas dentro de la Ciudad de México y las caravanas que se llevan a cabo en otras regiones de la nación. Como he señalado, la intención de acompañamiento es fundamental en las ofrendas nuevas de Teloloapan, pero en el contexto del movimiento social adquiere además una dimensión política: la de solidarizarse y atestiguar. Aquí se manifiesta el poder de la empatía: la pérdida de un hijo es una experiencia con la que casi cualquiera se puede identificar, aunque sea imaginativamente. Diana Taylor afirma que la trasmisión de la experiencia traumática se asemeja al contagio: "uno se contagia de y corporaliza la carga, el dolor y la responsabilidad de conductas y acontecimientos del pasado" (The Archive 168). La empatía y la solidaridad son efectos de la labor afectiva realizada por los integrantes del movimiento, que demuestra de ese modo su eficacia. A través de tal labor se genera comunidad.

La solidaridad empática no es, sin embargo, el único afecto desplegado en las marchas. Este tipo de manifestaciones implican además encuentros con otros sujetos, sobre todo los agentes del Estado. Ellos también emprenden por su parte labores afectivas: a través de su performance corporal y discursivo intentan transformar los ámbitos de protesta social en entornos de miedo y desconfianza, donde se manifiesta explícita y a veces brutalmente el poder del Estado para vigilar, manipular, categorizar y castigar a sus ciudadanos. Las expresiones de la labor afectiva resultan entonces diversas: se dan en las protestas colectivas, desde abajo, pero también en las intervenciones gubernamentales, desde arriba (Thomas y Correa, Affective Labour 224).

En esta revisión del despliegue y distribución del afecto, hay que considerar además la intensa labor al respecto de los grupos delictivos, que muchas veces en colusión con el Estado infunden miedo, incertidumbre y desesperación en los pobladores a través de un conjunto de exhibiciones de violencia extrema que deja huellas imborrables en los cuerpos y las mentes de sus víctimas y testigos.

\section{El rostro de Julio}

Reflexionando nuevamente sobre el papel fundamental que Levinas y otros intelectuales han otorgado al rostro dentro del pensamiento - rostro que al mirarnos puede entenderse como una especie de "evento ético" (en Taussig, Defacement 223) -, el hecho de que uno de

aparentemente está oculta detrás de las operaciones de poder, pero por otro, consiste en un entramado de relaciones, actores e interacciones que permea la vida cotidiana de las personas. Para más sobre esta discusión, ver Abrams ("Notes on the Difficulty"), Trouillot ("The Anthropology") y los distintos textos del libro editado por Sharma y Gupta (2006), entre muchos otros. 
los normalistas asesinados aquella noche haya sido desollado y su cuerpo sin cara arrojado a una calle de Iguala, resulta particularmente significativo (como si señalara justamente el estatus de no-sujetos de los jóvenes estudiantes indígenas). La imagen del cráneo expuesto de Julio César Mondragón forma parte del repertorio simbólico-afectivo del movimiento. Sus familiares y otras personas solidarias han creado la organización "El Rostro de Julio" para contribuir a hallar justicia por su asesinato y a la reaparición de sus compañeros.

En noviembre de 2015, a petición de la familia Mondragón, peritos del Equipo Argentino de Antropología Forense (EAAF), la PGR y la CNDH - entre otras instancias- exhumaron sus restos para realizar una nueva autopsia, ya que las conclusiones de la primera resultaron haber sido inadecuadas. Los restos siguen actualmente en manos de la PGR, y hasta el momento, en enero de 2016, la familia sigue exigiendo el retorno del cuerpo de Julio César a su sepulcro. Se ha denunciado la lentitud y falta de procedimientos adecuados en la realización de la investigación respectiva y señalado que el Estado mexicano revictimiza a las víctimas de manera cotidiana. ${ }^{9}$

Este caso en particular no deja duda de que, aun cuando es posible llevar a cabo de manera normal los rituales de duelo, las víctimas de la violencia estatal no descansan en paz y a sus familiares se les niega la posibilidad de salir del luto.

\section{Reflexiones finales}

La construcción de una ofrenda es, en Teloloapan, un momento dentro del ciclo de prácticas que rodean a la muerte, una manera de marcar la pérdida mediante el despliegue de un conjunto de objetos que evocan recuerdos en todos los allegados del difunto que participan en la creación y consumo de la ofrenda. Se trata de construcciones que convierten la trayectoria de vida de un individuo en una especie de exhibición teatral, que será consumida por un público que puede incluir a familiares y amigos, pero también a la gente de la localidad y — se esperaal espíritu mismo del difunto. A través de la formulación de ensamblajes de imágenes, palabras y objetos, donde todos los sentidos quedan involucrados, la labor afectiva del duelo se sirve de esta actividad para movilizar los procesos de la memoria, contribuyendo a sanar las heridas que deja el rompimiento abrupto de relaciones sociales, individuales y colectivas.

El caso de los familiares de los desaparecidos de Iguala es más complicado, ya que revela los límites del duelo "normal". Por la misma condición liminar que implica el estatuto de "desaparecidos" - la cual además hace eco de la invisibilidad estructural de estos jóvenes

${ }^{9}$ http://elrostrodejulio.org/2016/01/10/por-que-no-ha-sido-reinhumado-el-cuerpo-de-julio-cesar-mondragon-fontes/, consultado el 15 de enero del 2016. 
como estudiantes campesinos e indígenas-, este tipo de difuntos no puede ser objeto de procesos que permitan manejar de manera "sana" la pérdida, a pesar del aire de luto que rodea a las marchas $u$ otras acciones políticas y del despliegue de imágenes y objetos que sustituyen a los ausentes en varios contextos.

La insistencia de las madres y padres de los desparecidos para que el gobierno encuentre "vivos" a sus hijos, reclamo posibilitado por la ausencia de los cuerpos identificables y enterrables, funciona como una crítica al gobierno y una demanda por justicia, no solamente para estos 43 sino para todos los desaparecidos. Como señala Muñoz, para los sujetos queer o pertenecientes a minorías raciales, así como para los familiares de los desaparecidos, el duelo "es un mecanismo que nos ayuda a (re)construir la identidad y llevar a nuestros muertos con nosotros a las variadas batallas que tenemos que librar en su nombre (y en nuestros nombres)" (en Eng y Kazanjian, "Introduction: Mourning Remains" 363).

En vez de buscar consuelo en la creencia en un cielo como el que propone el imaginario católico, representado plásticamente en las ofrendas teloloapenses, los padres de familia de Ayotzinapa apuestan por el sueño de una nación solidaria, construida con base en la equidad y la justicia: "Todos somos Ayotzinapa”. Nos muestran así que el duelo y el activismo no se excluyen mutuamente, los dos ámbitos quedan sujetos en este caso a un juego de presencias y ausencias, de personas y posibilidades. Tanto las ofrendas nuevas de Teloloapan como las marchas y acciones de protesta de los familiares y simpatizantes de los normalistas de Ayotzinapa, visibilizan mediante su labor afectiva un mundo ideal, un mundo como debe o podría ser. Esto implica que el mundo actual se considera incompleto debido a la pérdida o conjunto de pérdidas sufridas.

La pérdida, sobre todo aquella ocasionada por violencia, nos expone como sujetos vulnerables (Butler, Precarious Life 28). Deja truncadas a las personas que la sufren y en general a toda la sociedad. Pero al recordarnos nuestros lazos afectivos con otros seres humanos y la responsabilidad ética que tenemos hacia ellos, aquellos que comparten su duelo - tanto en el luto "normal" como en el duelo indignado- permiten la emergencia de un sentido de comunidad o hasta de un movimiento político colectivo.

\section{Bibliografía}

Abrams, Philip. "Notes on the Difficulty of Studying the State". Journal of Historical Sociology, vol. 1, núm. 1, 1988 [1977], pp. 59-89.

Bachelard, Gaston. La Poética del espacio. Trad. Ernestina De Champourcin. México: Fondo de Cultura Económica, 1975. 
Bartra, Roger. La jaula de la melancolía. Identidad y metamorfosis del mexicano. México: Grijalbo, 1987.

Bowring, Jacky. A Field Guide to Melancholy. Harpenden: Oldcastle Books, 2008.

Butler, Judith. Precarious Life: The Powers of Mourning and Violence. Londres: Verso, 2004.

Das, Veena y Deborah Poole. "State and its Margins: Comparative Ethnographies". Anthropology in the Margins of the State. Eds. Veena Das y Deborah Poole. Santa Fe: School of American Research Press, 2004, pp. 3-34.

Davis, Natalie y Randolph Stern. "Introduction to Special Issue on Memory and Counter-Memory". Representations, vol. 26, 1989, pp. 1-6.

Diéguez, Ileana. Cuerpos sin duelo: Iconografías y teatralidades del dolor. Córdoba, Argentina: Ediciones DocumentA/Escénicas, 2013.

Eng, David L. y David Kazanjian. "Introduction: Mourning Remains". Loss: The Politics of Mourning. Eds. David L. Eng y David Kazanjian. Berkeley - Los Angeles: University of California Press, 2003, pp. 1-28.

Freud, Sigmund. Trabajos sobre metapsicología, duelo y melancolía (Tomo XIV). Buenos Aires: Amorrortu, 1917 [1915].

González, Jennifer A. “Autotopographies”. Prosthetic Territories: Politics and Hypertechnologies. Eds. Gabriel Brahm Jr. y Mark Driscoll. Boulder: Westview Press, 1995.

Johnson, Anne W. Diablos, insurgentes e indios: política y poética de la historia en el Norte de Guerrero. Ciudad de México: Secretaría de la Cultura / Instituto Nacional de Antropología e Historia, 2016.

Navarro-Yashin, Yael. "Affective Spaces, Melancholic Objects: Ruination and the Production of Anthropological Knowledge". Journal of the Royal Anthropological Institute, vol. 15, 2009, pp. 1-18.

Nora, Pierre. "Between Memory and History: Les lieux de memoire". Representations, vol. 26, 1989, pp. 7-25.

Ovando, Pedro. "La fuerza de la desaparición. Notas acerca de la construcción performativa de los símbolos". Diario de Campo, núms. 6-7, 2015, pp. 55-61.

Parrini, Rodrigo. "La memoria como desecho. Las prendas de un ropero para migrantes". Ponencia. Primer Coloquio sobre Memoria Colectiva, Instituto Nacional de Antropología. Ciudad de México, 2015.

Serementakis, C. Nadia. "The Memory of the Senses, Part I" y "The Memory of the Senses, Part II". The Senses Still: Perception and Memory as Material Culture in Modernity. Ed. C. Nadia Serementakis. Chicago-Londres: University of Chicago Press, 1994, pp. 1-43.

Sharma, Aradhana y Akhil Gupta, eds. The Anthropology of the State: A Reader. Malden, MA: Blackwell Publishing, 2006. 
INVESTIGACIÓNTEATRAL

Revista de artes escénicas y performatividad

Vol. 9, Núm. 13

abril-septiembre 2018
La labor afectiva del duelo: ofrendas, pérdidas y desapariciones en Guerrero

Anne W. Johnson

Stewart, Susan. On Longing: Narratives of the Miniature, the Gigantic, the Souvenir, the Collection. Baltimore: The Johns Hopkins University Press, 1993.

Taussig, Michael. Defacement. Public Secrecy and the Labor of the Negative. Nueva York: Routledge, 1999.

Taylor, Diana. The Archive and the Repertoire. Durham: Duke University Press, 2003.

Thomas, James M. y Jennifer G. Correa. Affective Labour: (Dis)assembling Distance and Differenc. Londres-Nueva York: Rowman \& Littlefield International, 2016.

Trouillot, Michel. "The Anthropology of the State in the Age of Globalization: Close Encounters of the Deceptive Kind". Current Anthropology, vol. 42, núm. 1, 2001, pp. 125-138.

Trouillot, Michel. Silencing the Past: Power and the Production of History. Boston: Beacon Press, 1995.

Tuan, Yi-Fu. Space and Place: The Perspective of Experience. Minneapolis: University of Minnesota Press, 1977. 


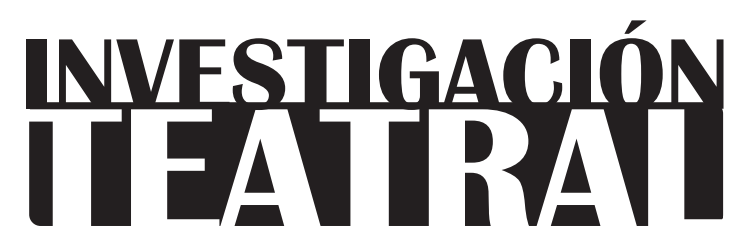

Revista de artes escénicas y performatividad

Vol. 9, Núm. 13

abril-septiembre 2018

Segunda época

ISSN impreso: 1665-8728

ISSN electrónico: 2594-0953

Universidad Veracruzana

\section{"Alerta sísmica": teatro y heterotopías}

Patricio Villarreal Ávila*

"Integrante del colectivo Teatro Ojo, México.
e-mail: patrocloherido@gmail.com

Recibido: 13 de mayo de 2016

Aceptado: 07 de febrero de 2017 


\section{"Alerta sísmica": teatro y heterotopías}

$\mathrm{E}$ 120 de octubre de 2016, el colectivo mexicano Teatro Ojo participó en la segunda edición del coloquio "Indagaciones multidisciplinarias en las prácticas de investigación en artes y ciencias sociales" con un laboratorio llamado "Alerta sísmica". El laboratorio - al igual que el resto del coloquio- se llevó a cabo en el salón Panorama del Centro Cultural de España (CCE), ubicado entre las calles República de Guatemala y Donceles, en el Centro Histórico de la Ciudad de México. Esas condiciones fueron esenciales para su desarrollo conceptual, estético, narrativo y práctico, gracias a que el salón funciona como terraza y mirador, desde donde se puede observar una parte importante de la capital mexicana. También es relevante porque esa zona es lugar de constantes descubrimientos arqueológicos, mismos que atraviesan gran parte de la producción del colectivo, como se verá más adelante.

Para retomar el ya largo trabajo que el colectivo lleva a cabo en torno a la ciudad y el arte público (desde su creación en 2002), la idea que presentaba "Alerta sísmica" no era sólo un nombre divertido y gratuito, sino una forma de dar lugar a algo que nombraré aquí como un "sedimento anímico-psíquico" alrededor del siempre posible advenimiento del sismo en nuestro país. ${ }^{1}$ Esa alta probabilidad del retorno del sismo organiza, por una parte, una serie de comportamientos urbanos y civiles incorporados por las propias instituciones, pero, por otra, tiene la capacidad de disparar estados individuales y colectivos que van de la

1 Un año después, en septiembre del 2017, dos fuertes terremotos impactaron la región centro-sur de México, resultando en cerca de 500 decesos, decenas de miles de personas damnificadas y edificios destruidos. El autor se refiere al segundo de estos sismos al final del presente artículo [N. del Ed.] 


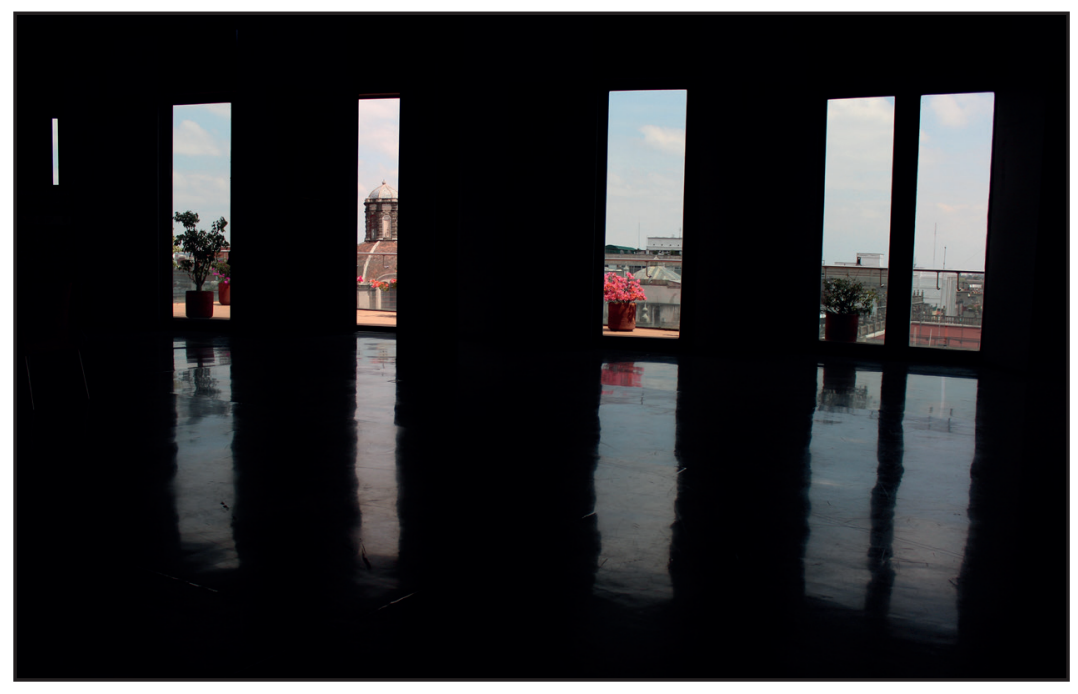

Salón panorama CCEMX. Ciudad de México. Octubre 2016. Fotografía de Alonso Arrieta/Teatro Ojo.

angustia al instinto de sobrevivencia y que, algunas veces, pueden desbordar las reacciones ante el fenómeno telúrico. A veces tales reacciones aparecen en forma de lo insospechado y no sólo son una respuesta inmediata ante el temblor, sino también un escape de lo que el constante vaivén telúrico acumuló en cada persona durante un tiempo determinado, como si un pulso salido de las capas geológicas bajo la tierra marcara el ritmo de múltiples formas de vida y existencia que van más allá de lo humano.

El sismo ocurrido en la Ciudad de México el 19 de septiembre de 1985 provocó, por una parte, miles de pérdidas humanas y un inabarcable cálculo de devastaciones materiales, además de que dio pie al derrumbe de la figura presidencial —así como del Estado al que pertenecía - gracias a su lamentable actuación. Sin embargo, hizo aparecer una solidaridad y organización ciudadana de dimensiones rara vez vistas en la ciudad. Luego de dicho suceso, una cultura cívica en torno al terremoto dio inicio, junto con la cual se gestó toda una gramática simbólica y social para prevenir los peores desastres.

Posicionado en un lugar radicalmente distinto al lenguaje explícito utilizado para comunicar la prevención frente al temblor, el ejercicio del laboratorio - que no era otra cosa sino una posible estrategia artística para abordar y repensar procesos de trabajo grupal- consistía en abrir una interrogante sobre aquello interiorizado por los integrantes del grupo a partir de la experiencia misma del terremoto y que, podríamos decir, funciona como parte de una memoria corporal y anímica que nos conecta con el afuera, la ciudad y el espacio público.

A través del constante desplazamiento de preguntas, formas estéticas y diversas estrategias, Teatro Ojo ha buscado, en los distintos lugares y momentos en que ha llevado a cabo su trabajo escénico, primero el rastro y después el registro de ciertas vibraciones 


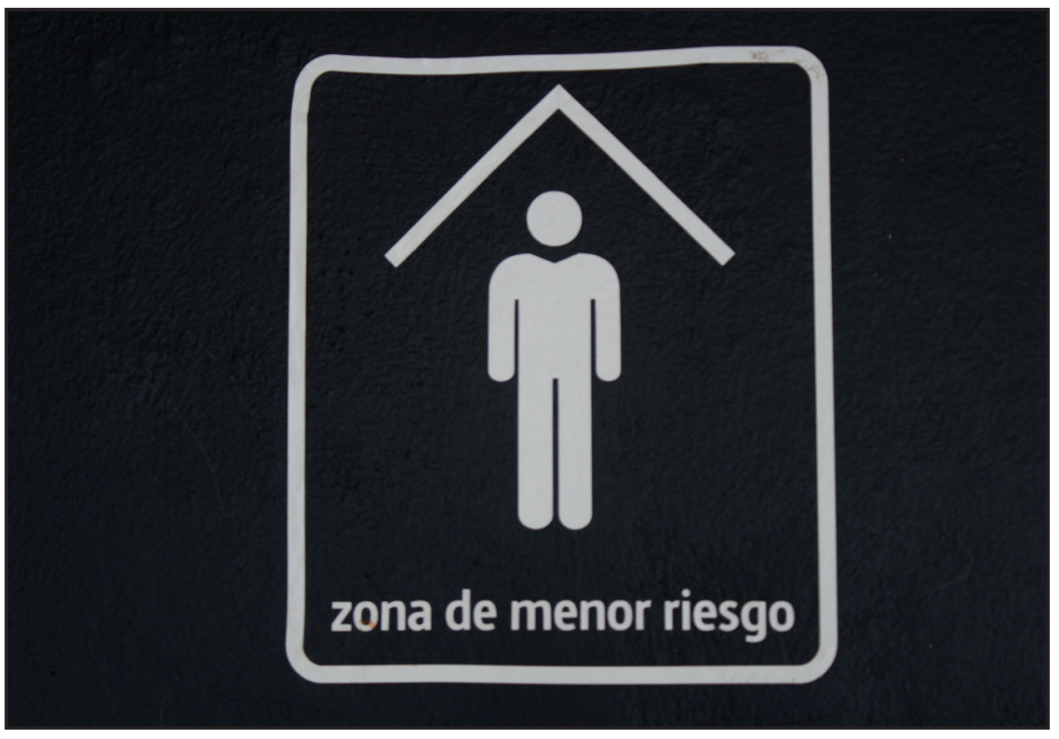

Experimentos para el laboratorio. Ciudad de México. Octubre 2016. Fotografía de Alonso Arrieta/Teatro Ojo.

- consecuencia discontinua de los movimientos tectónicos - cuyas sacudidas hayan dejado traza en entidades diversas, lo que las transforma en fuente de creación y producción para el grupo. Entidades como la materialidad pétrea y ruinosa hallada en las paredes de edificios emblemáticos para la historia moderna mexicana; en la agitación provocada por múltiples timbres de voces afectadas por las distintas formas de violencia propias de estos últimos años, los cuales fueron esparcidos dentro y fuera de algún teatro; en la circulación volátil y eléctrica lanzada a través de micro-videos cargados de presente que interrumpen la programación de canales específicos de televisión e internet; en el hedor melancólico emanado de piezas plásticas producidas para convertirse en basura, y que en el viaje que hacen por la ciudad intentan ser recuerdo y extrañamiento de algún acontecimiento de la historia.

Esas entidades, marcadas por alguna huella vibrátil que hace detener la mirada, no podrían agruparse en categoría alguna que no sea la del deseo compartido; existen desperdigadas en y alrededor de esto que llamamos ciudad. Para el grupo, algunas veces parecen grietas que dejó el último temblor, pero otras son fallas de las que vendrá el siguiente. Estimulados por la figura del sismógrafo proveniente de los mundos imaginados por el historiador de arte Aby Warburg (como expone Didi-Huberman en La imagen superviviente), la articulación que el grupo hace de los lugares que aproxima $-\mathrm{y}$ del momento que estos atraviesan - consiste en la búsqueda de aquello que ha quedado inscrito por las vibraciones que derrumban, perturban, transforman y dan origen a un sinnúmero de comportamientos integrados al espacio urbano. 
Si consideramos que el trabajo artístico podría ser una forma de inscripción hacia otro tipo de conocimiento, el laboratorio se pensaba como el despliegue plástico, narrativo y performativo de la espera constante del próximo temblor. Un nuevo sismógrafo. En ese sentido, no se trataba de abordar la sintaxis explícita de su prevención, sino de acceder a un orden más bien implícito en la estructura psíquica que involucra fuerzas premonitoras, más próximas al presentimiento y la predicción de su inminente llegada. Presentir, mejor que prevenir, y así desatar la imaginación. De este modo, cabía la posibilidad de imaginar el sismo como un movimiento que se extiende más allá de la tierra, hacia el ambiente y el cielo, hacia el tiempo y la historia, hacia el deseo y la memoria. Memoria de la gente, pero también de las cosas.

El ejercicio escénico del laboratorio consistió en abordar el conjunto "ciudad-temporalidad-proyectos artísticos", a través de materiales impresos (fotografías, recortes de periódico, entro otros) dispersándose por todo el salón. Desparramadas unas sobre otras, encima de una larga mesa, las imágenes se pegaron en las ventanas del salón Panorama, haciendo una referencia más bien discontinua y desorganizada de la geografía urbana específica que se relataba in situ por los integrantes del grupo. Cada una de estas referencias se pensaba como el entrecruce de lugares y acontecimientos específicos, a los cuales nosotros imaginábamos como el origen de aquellos temblores cuya fuerza se ha inscrito en los propios integrantes hasta transformarse en un proyecto artístico.

En un trabajo sobre la producción arcaica del mito, Hans Blumenberg dice que, en el tránsito constitutivo de la caverna a la sabana, el ser humano, ante el advenimiento de una siempre latente catástrofe proveniente del horizonte infinito, desarrolló una "angustia vital y anticipatoria", productora de abigarradas formas estéticas que mediaban entre los humanos y su entorno (El trabajo 14). Es una forma de leer el absoluto de la naturaleza y el mundo y poco a poco dibujar nuestra propia inscripción psíquica sobre lo manifiesto.

Así fue como la antigua figura del templum latino se impuso con fuerza. Un rectángulo trazado por un augur, después de calcular el punto exacto entre la tierra y el cielo, era la bisagra para erigir un templo sagrado, fuente de augurios. Respecto al método que los romanos usaban para adivinar el futuro, la respuesta al augurio era el vuelo de los pájaros en algunos relatos, y en otros el paso resplandeciente del relámpago. Para el laboratorio, la referencia al templum se daba al mirar por las ventanas de aquel salón del CCE como un singular ejercicio adivinatorio vinculado a algún acontecimiento pasado, pero que mantiene toda la fuerza de manifestarse e irrumpir en el presente.

Dado que el recorrido narrativo del laboratorio abordaba una trayectoria no-lineal de casi quince años de experimentación escénica, vinculada al templum como artefacto premonitor, la imagen de una mantis religiosa empezó a invadir el primer recuerdo de Teatro Ojo. Una mantis religiosa hembra que decapita al macho en el momento mismo del apareamiento era el centro de la primera puesta en escena de Teatro Ojo: Salomé o el pretérito 


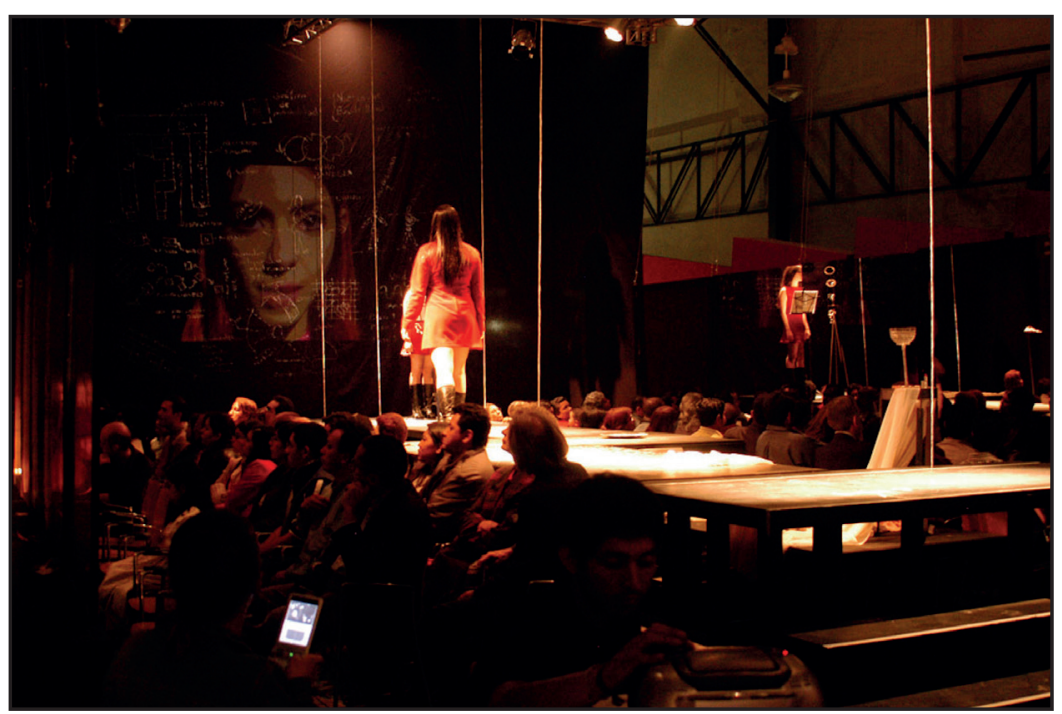

Salomé o el pretérito imperfecto. Ciudad de México. Octubre 2003. Fotografía de Pablo Villegas/Teatro Ojo.

imperfecto. Roger Caillois nos recuerda que en el nombre de la llamada "mantis" subyace la figura, la presencia de una profetisa: un ser de la adivinación y de la premonición (El mito 43). Una figura femenina con el poder de anticipar el futuro. Acaso esa actitud anticipatoria produjo una infinitud de mitos en torno a la figura de la mantis misma. Figura sagrada, diabólica, familiar, siniestra, sumamente mágica y poderosa.

Salomé o del pretérito imperfecto tuvo lugar en 2003 en el patio del Centro Cultural de España, justo cinco pisos debajo del salón donde se llevó a cabo el laboratorio "Alerta sísmica". No sabíamos entonces que unos metros debajo de nosotros se escondían las piedras de lo que en otro tiempo fuera la cima de la escuela o monasterio de la nobleza mexica: el Calmécac. Bajo la fachada del edificio de esta cooperativa española, dedicada a la exposición y desarrollo de las artes, hoy está ya descubierto un fragmento del lugar destinado al desarrollo del arte de gobernar la ciudad sagrada: sacerdotes, guerreros, científicos, economistas, nigromantes se formaban en ese lugar. ${ }^{2}$ Organizado en los llamados amoxtli o libros sagrados, todo el conocimiento de lo venidero constituía las formas de vida de una ciudad que subyace hoy bajo esta otra ciudad que habitamos.

Es la memoria del subsuelo de la Ciudad de México, es la memoria de innumerables piedras que permanecen ahí, como sostén y amenaza de la ciudad actual, piedras que se

${ }^{2}$ Habría que agregar que después del hallazgo del Calmécac en esa zona se excavó, durante los días del coloquio, para descubrir lo que en meses posteriores se supo que era el Gran Tzompantli de la ciudad sagrada. Véase la nota de Alec Forssmann (2017), publicada en la revista National Geographic respecto a este hallazgo ("Hallan calaveras"). 


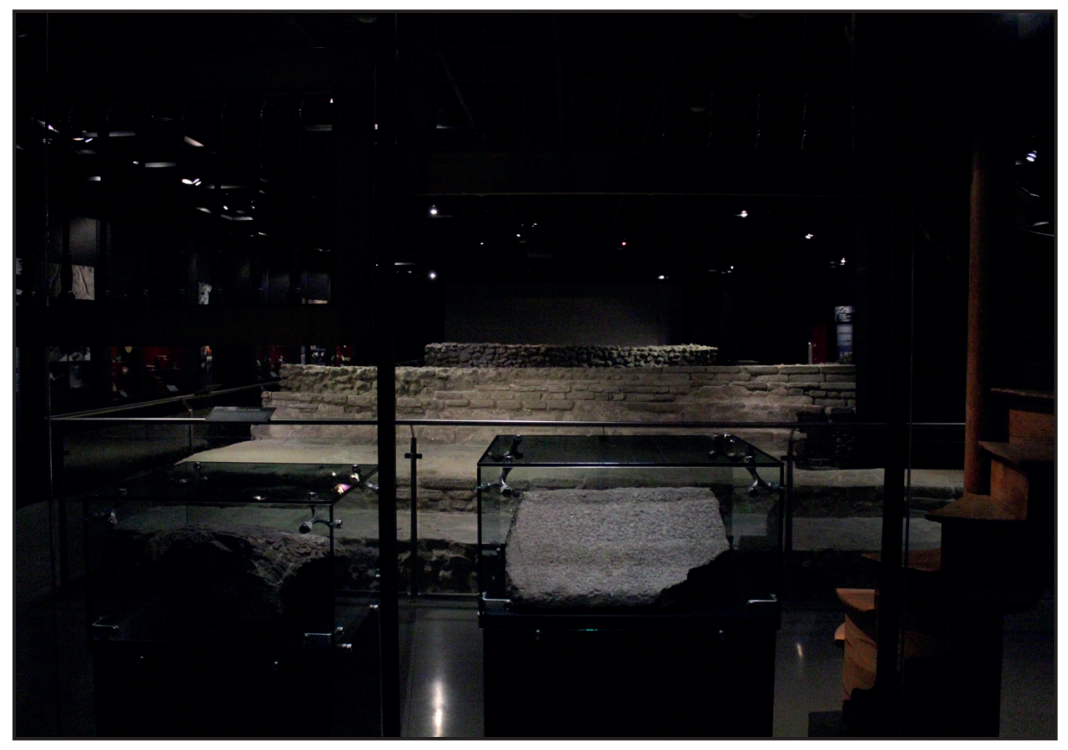

Calmécac. Ciudad de México. 2016. Fotografía de Fernanda Villegas/Teatro Ojo.

mueven y chocan entre sí. Amenaza de nuevos temblores que, a través de aquello que derrumban, nos devuelven otra imagen de lo que también somos: un constante hundimiento entre el lodo que nos rodea; un continuo abrir de grietas entre las que aparecen otras piedras. Pues un terremoto, sacude, derrumba. Frente al temblor de su propio cuerpo, que anunciaba su próxima muerte, Jacques Derrida dijo: "la sacudida sísmica y sus réplicas pueden convertirse en metáforas para designar toda mutación perturbadora (social, psíquica, política, geopolítica, poética, artística) que obliga a cambiar de terreno brutalmente, es decir, imprevisiblemente.” (“Cómo no temblar?” 23).

¿Qué mutación perturbadora e imprevisible tuvo el terreno de esta ciudad -o de esta nación- cuando en 1790 reapareció, a unos pasos de aquí, en la Plaza de la Constitución, la primera piedra que al desatar innumerables fuerzas religiosas y culturales evidenciaba el origen de esa entidad nacional llamada México como la construcción de una historia en profunda disputa? Esa primera piedra era el monolito de la Coatlicue: diosa madre de dioses, origen de la tierra. Una piedra viva y no una mera representación escultórica de la diosa.

Las palabras de Roger Caillois en su trabajo sobre las piedras son elocuentes: "Ciertas piedras son divinas, imágenes o habitáculos de los dioses, diosas por sí mismas" (Piedras 35). El laboratorio lanzaba esas preguntas sobre la coincidencia de tiempos rotos, rasgados, discontinuos. ¿Por qué coincidió la fecha de reaparición de la Coatlicue, el 13 de agosto de 1790, con la de la caída de Tenochtitlán, pero 269 años después?

Desde el Museo de Antropología e Historia de la Ciudad de México —donde está instalada-, la Coatlicue nos devuelve sus atributos que recuerdan la forma acuosa, llena de lodo 
y pantanosa que todavía es este lugar, pues es la diosa de la falda de serpientes. En esa falda aparecen también surcos de agua y tierra que permiten imaginar la vida de otro tiempo, así como otros posibles recorridos, derivas y pasajes de nuestra ciudad actual, al igual que todas las posibles formas de supervivencia que se asoman desde las grietas que va dejando cada sismo. Pero, también, el lugar donde estamos parados, cierta medida de cómo sentimos los temblores actualmente.

Durante el laboratorio, en el recuento que Teatro Ojo hace de sus propios proyectos, se suelen confundir las piedras y los movimientos ligados a ellas; se borran las sanas diferencias entre las capas tectónicas y esas piedras otrora sagradas, devenidas hoy en objetos culturales para la contemplación turística. Presentir el terremoto no está alejado del recuerdo de otros sismos que pertenecen a la historia.

Pascal Quignard afirma que cuando dos civilizaciones antagónicas rozan sus bordes, producen sacudidas sísmicas para la historia, como fue el encuentro de los mundos griegos y latinos hace veinte siglos (El sexo 7-10). Hace cinco, en esta geografía, una sacudida de civilizaciones sumamente violenta tuvo lugar dando origen a un cúmulo de mundos entrelazados como una maraña, inconmensurable sacudida con réplicas y réplicas. Pero ¿por qué coinciden terriblemente —algunas veces- las fechas del calendario? ¿Es señal de la importancia que tienen los aparatos de sabiduría predictiva? ¿Son el recuerdo de la fuerza condensada que produjo artefactos tan dispares como el templum, la oniromancia, la mantis religiosa o el tonalpohualli? ${ }^{3}$

Once meses después del laboratorio "Alerta sísmica", y 32 años después del terremoto de 1985 - exactamente en la misma fecha de aquel devastador sismo-, otro temblor tomó por sorpresa el centro de la República Mexicana, provocando el derrumbe de nuevos edificios y cobrando nuevas vidas bajo los escombros. Aunque de una magnitud menor a lo padecido en el año 85, este terremoto desató todo un abanico de emociones, pensamientos, comportamientos y enunciaciones que, desbordados, inundaron el espacio de la ciudad, dando lugar a otra gramática desordenada. Ese fatal encuentro entre suelo y temblor desarticula la prevención que aprendimos como medida de protección, todo se vuelve puro presente suspendido entre lo trágico y el horror. Por un instante derrumba el trayecto de nuestro tiempo moderno y acontece un aliento apenas para presentir la distancia por donde hizo su tránsito la muerte. Con suerte no se detuvo todo aquí, con suerte no hay que empezar totalmente de nuevo. Seguimos sobre una terraza - como nuevos animales del aire - mirando la ciudad como foco de atracción o como pieza artística a la escucha de lo que relatan los artistas de Teatro Ojo.

3 El tonalpohualli, o calendario adivinatorio, fue un artefacto nahua para predecir el transcurso de los días en una compleja relación entre tiempo humano y tiempo mítico (Gruzinski 1991, 25). 


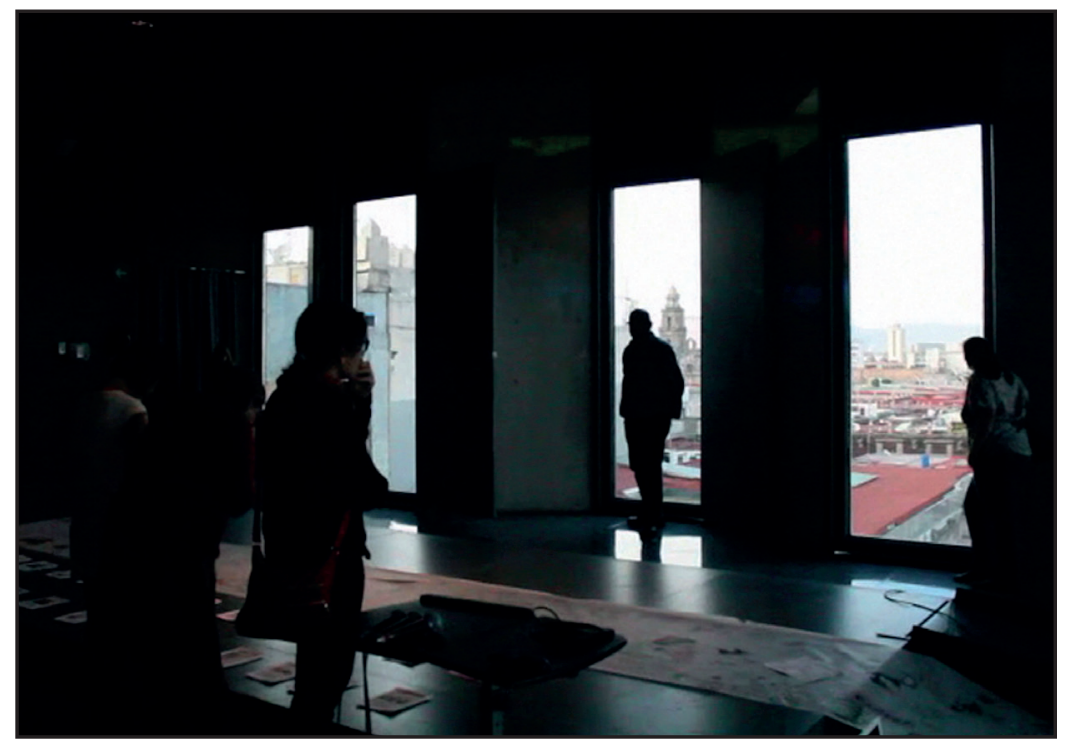

Fotograma del laboratorio "Alerta sísmica". Ciudad de México. 2016. Fotografía de Alonso Arrieta/Teatro Ojo.

Envueltos en esa atmósfera, olvidándonos de que el temblor llega siempre como llega lo más inesperado. La espera infinita de lo inesperado. Pero, desafortunadamente, ese día no fue así. Ese día el sismo nos alcanzó y, tras él, el comienzo de todas las nuevas premoniciones para intentar — en medio de la desdicha - adivinar e imaginar la futura forma de lo que viene.

\section{Bibliografía}

Blumenberg, Hans. El trabajo sobre el mito. Barcelona: Paidós, 2003.

Caillois, Roger. Piedras. Madrid: Siruela, 2011.

Caillois, Roger. El mito y el hombre. Buenos Aires: Sur, 1939.

Derrida, Jacques. “¿Cómo no temblar?”. Trad. Esther Cohen. Acta Poetica, vol. 30, núm. 3, 2009, pp. 19-34.

Didi-Huberman, Georges. La imagen superviviente. Historia del arte y tiempo de los fantasmas según Aby Warburg. Madrid: Abada, 2009.

Forssmann, Alec. "Hallan calaveras de mujeres y niños en el Gran Tzompantli de la antigua Tenochtitlán”. National Geographic, 4 de julio de 2017, en línea. Consultado el 10 de octubre del 2017.

Gruzinski, Serge. La colonización de lo imaginario. Sociedades indígenas y occidentalización en el México español. Siglos XVI-XVIII. México: Fondo de Cultura Económica, 1991.

Quignard, Pascal. El sexo y el espanto. Barcelona: Minúscula, 2005. 


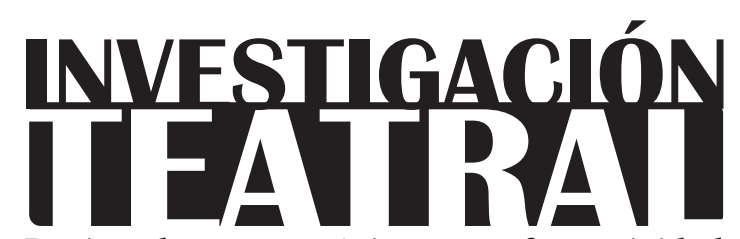

Revista de artes escénicas y performatividad

Vol. 9, Núm. 13

abril-septiembre 2018

Segunda época

ISSN impreso: 1665-8728

ISSN electrónico: 2594-0953

Universidad Veracruzana

\title{
El teatro como crítica institucional
}

\author{
Óscar Cornago*
}

\author{
* Consejo Superior de Investigaciones Científicas, \\ Madrid, España. \\ e-mail: oscarcornago@yahoo.com
}

Recibido: 20 de julio de 2017

Aceptado: 12 de diciembre de 2017 


\title{
El teatro como crítica institucional
}

\section{Resumen}

Este artículo discute el sentido de las prácticas teatrales en relación a los contextos institucionales en los que se desarrollan. Para ello, se analiza la dimensión institucional del teatro en relación a las artes visuales. La reacción ante repertorios de formas y usos ya instituidos ha abierto un ámbito de confluencias entre las prácticas performativas y las visuales. Con el fin de trazar diversos recorridos dentro de este panorama, se estudian proyectos de creación de España, Alemania, México, Líbano y Brasil, algunos de ellos pertenecientes a la programación de la in Mostra Internacional de Teatro de São Paulo del 2017. Estas obras intervienen sobre los marcos ya legitimados de actuación, con el fin de cuestionar la construcción institucional del teatro, abriendo nuevos posibilidades de creación y reflexión en relación al espacio de la representación.

Palabras clave: institución, legitimación, lugares de actuación, teoría escénica, teatro contextual, Brasil.

\section{Theatre as Institutional Critique}

\begin{abstract}
This article discusses the meaning of theatrical practices in relation to the institutional contexts in which they develop. Attention is paid to the institutional dimension of theater in relation to the visual arts. The reaction to established repertoires has opened a confluence between performative and visual practices. In order to trace different routes within this panorama, projects from Spain, Germany, Mexico, Lebanon and Brazil are studied, some of them belonging to the programming of the III International Theater Festival of São Paulo (2017). These plays intervene in the legitimated frameworks around performance, with the purpose of questioning the institutional construction of theater while opening possibilities of new territories of creation and critique within the spaces of representation.
\end{abstract}

Keywords: Institution, Legitimation, Places of Acting, Performing Theory, Contextual Theatre, Brazil. 


\section{El teatro como crítica institucional}

\section{¿Instituciones de aficionados?}

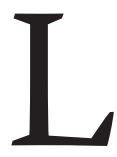
a figura del aficionado desafía la lógica de la institución. En tanto que "cosa establecida o fundada", según la definición de "institución" que ofrece el diccionario de la RAE, el único lugar que puede ocupar un aficionado es como cliente o usuario, en todo caso, el de un personaje de paso por un espacio cuyo capital simbólico se apoya en lo ya instituido, pero cuyo potencial activo descansa, sin embargo, en su capacidad instituyente, atendiendo a un presente en movimiento. El aficionado pone en riesgo la legitimidad de la institución, pero, al mismo tiempo, la institución necesita de él para luchar contra la endogamia implícita en una dinámica de profesionalización.

El interés que la figura del aficionado despierta en el campo de las artes es una respuesta a la reacción, a la institucionalización de las prácticas artísticas en ámbitos perfectamente definidos. No hay que entender dicho interés como un ataque al conocimiento, al saber hacer o a la necesidad de estudio, sino al peligro de aislamiento y autonomía inherente a los procesos de especialización. El aficionado apela a un territorio humano que se alimenta del no saber y la pasión por el saber, el gusto por seguir aprendiendo y reinventándose uno mismo en relación a un horizonte cognoscitivo, más allá de rentabilidades de otro orden. La falta de credibilidad en las instituciones -incluyendo las del arte y el teatro- que caracteriza a los sistemas políticos contemporáneos, tiene sus raíces en la distancia con la que desde afuera se perciben esas complejas construcciones públicas que deberían estar al servicio de todos, incluidos, por supuesto, los aficionados. 
En Amateur $^{1}$ (2016) el artista, actor, director y dramaturgo es un intérprete de piano que desde el inicio se presenta como aficionado. La obra dura lo que dura la partitura elegida para la ocasión. En la primera edición fue una pieza del compositor renacentista Orlando Gibbons, en la segunda las Variaciones Goldberg de Johann Sebastian Bach. Al mismo tiempo que se interpreta la pieza, se proyecta un texto del ejecutante escrito en primera persona, dónde éste explica al público lo que está tocando y le habla de su relación con la música, especialmente el piano, tema que, a su vez, lo lleva a tratar muchas otras cuestiones. En principio parece que el único elemento que permite identificar a la obra como un evento teatral - y no solamente un concierto - es el texto proyectado en el escenario, pero hay otro factor que debemos tener en cuenta y que podría pasar fácilmente desapercibido: el marco cultural, tipo de programación o espacio institucional que acoge a la propuesta —en este caso, ámbitos dedicados a las artes escénicas- - La obra podría hacerse perfectamente en un auditorio de música clásica, incluso con la proyección del texto, pero el efecto teatral (o antiteatral) ya no sería el mismo.

En caso de interpretarse en un auditorio, la obra pasaría a ser lo que literalmente es: un concierto de piano al que se añade una mirada autorreflexiva. Dicha mirada, sobre la que se construye el efecto teatral que caracteriza a la obra, opera como un tercer ojo que impide que nos olvidemos del lugar en el que nos encontramos y lo que estamos haciendo allí. La teatralización del momento nos hace percibir lo que está pasando en relación a una serie de contingencias externas al propio concierto, pero que lo determinan. Esos elementos, que podemos denominar contextuales, tienden a pasar inadvertidos: cuestiones como la presencia silenciosa del público protegido por la oscuridad del patio de butacas, la relación del autor (gracias a la reciprocidad de los espectadores) con lo que está pasando en el escenario, así como el tipo de estímulo que lo llevó a aceptar dicho trabajo; finalmente, lo que se cobra por asistir al espectáculo y lo que llevó al público a acudir al teatro la noche de la función. En "condiciones normales de recepción”, el público abstraería todos estos elementos, los pondría entre paréntesis para sumergirse en el viaje interior al que invita la partitura. Pero nombrarlos o señalarlos a través del texto, hace que la percepción de la obra varíe sustancialmente y que esas variaciones no sean ya sólo musicales, sino también escénicas, dependientes del lugar y el contexto en el que se interpretan.

1 Amateur es un proyecto que se crea en 2016 como parte de un programa de residencias del espacio Nyamnyam de Barcelona. Hasta el momento ha tenido dos ediciones: Gibbons Amateur (2016) y Goldberg Amateur (2017). Se ha realizado en Teatro Pradillo (Madrid), Antic Teatre (Barcelona), el Festival TNT (Terrassa) y el ciclo Teatro Raro de CiudaDistrito (Madrid). Puede consultarse más documentación y material gráfico en la página del artista: http://www.fuga.es/amateur/. 
Pero, ¿a qué llamaríamos “condiciones normales de recepción”? Las condiciones normales son aquellas marcadas por una cierta normativa o convención cultural acerca de cómo se debe hacer público un tipo determinado de obra y cómo se debe recibir. Dichas condiciones, convertidas en convenciones aceptadas por una sociedad, son las que invisibilizan los marcos de ocurrencia. En un concierto de piano, por ejemplo, tales condiciones están ligadas a un auditorio musical, cuyo marco cultural es justamente el horizonte del que se distancia Amateur. La escena le proporciona el medio para esta distanciación crítica. El ejercicio de distanciamiento, a su vez, es lo que en este caso teatraliza la obra, aunque en muchos casos - como en la interpretación de Amateur en el Centro Cultural Las Rosas de Madrid en 2017- sería posible que la diferencia radique únicamente en el uso que se hace del espacio.

Ahora bien, el desplazamiento no opera únicamente en relación al horizonte musical, sino que afecta también al contexto teatral. Se hace un uso desviado del espacio teatral, pues se le utiliza para ofrecer un concierto de piano que es - como se advierte en el textoprecisamente lo que se quiere evitar: dar un concierto de piano más. Para ello se recurre a la teatralización de la interpretación del pianista. Al teatralizarla, es decir, al hacer consciente al público de una serie de circunstancias personales y no personales que explican la historia del intérprete con la música (y más concretamente con la partitura que está interpretando), se crea otro tipo de situación pública que permite tomar distancia con respecto a los modos habituales de hacer y consumir la música antigua a través de esos eventos que se denominan "conciertos de música clásica", caracterizados por una serie de convenciones, actitudes, juicios y prejuicios.

Se trata de rasgos que forman parte de lo que podríamos llamar "la institución musical", la cual es tomada como objeto de la crítica planteada por Amateur. Ese tercer ojo, que se construye a través de un ejercicio de reflexión en voz alta, no sólo hace visible al intérprete mientras toca lo que aparentemente se le iría pasando por la cabeza, sino que señala también al público que se encuentra en silencio del otro lado del escenario, por más que en el texto se le provoque a adoptar actitudes diferentes. Pero alude, por otra parte, a los códigos culturales de la misma institución que acoge la obra: el tipo de espacio teatral en el que acontece la función, por ejemplo, haciendo referencias a lo que pasó en ese mismo espacio el día anterior, etcétera. Se muestra todo un ámbito en torno al acontecimiento, con el fin de reconsiderar el hecho singular de estar asistiendo a un concierto de música antigua sacado de los formatos que normalmente lo tendrían capturado.

La obra comienza con la entrada del intérprete en escena, inevitablemente también director y actor de la puesta. El piano esta frente al público desde antes, iluminado por una luz cenital. El músico se sienta de espaldas a la audiencia, se prepara un momento y comienza a tocar. Si por un lado se va a dirigir a los espectadores, por el otro parece olvidarse 
de su presencia, como si no quisiera saber nada de ellos, aunque tampoco le incomodan (algo que será comentado explícitamente). Poco después de iniciado el concierto, empiezan a aparecer los textos sobre el fondo del escenario. Se puntualiza que el intérprete no es profesional sino un aficionado - aunque una gran parte del público posiblemente no notaría la diferencia- y que hace eso porque le gusta, incluso se pide una disculpa por los posibles errores de interpretación. Dicho conflicto entre el significado de ser amateur o profesional será el eje sobre el que girarán gran parte de las reflexiones plasmadas. Lo profesional queda relacionado con el ámbito del trabajo, el deber, una rentabilidad clara, pero por ello también con las propias expectativas y el miedo a no estar a la altura de las mismas. El amateurismo, en cambio, se piensa en relación con el gusto por hacer las cosas desde una cierta gratuidad, incluso si no salen tan bien, con la posibilidad del error, la experiencia interior del aprendizaje y la satisfacción de notar ciertos progresos, aun renunciando a buscar la perfección. Se habla del tema de la democratización de los placeres, planteándole en algún momento al espectador: ¿te imaginas si el porno estuviera reservado únicamente a los profesionales?

La reflexión del texto proyectado no alude explícitamente al mundo escénico, pero es obviamente en el espacio y la institución teatrales donde repercute el uso desviado que se hace de la escena. Desde un punto de vista práctico - donde "práctica" se referiría no a la interpretación musical, sino a la actuación a través de la construcción subjetiva del texto-, es el teatro el medio donde resuenan dichas críticas. No es casualidad que sea ésta la perspectiva desde la que se sitúa la obra dentro del ciclo Teatro Raro ${ }^{2}$ de los distritos de Madrid:

Todo el mundo entiende esto. Lo que no encaja. Lo imprevisto. Lo inusual. Lo que no ocurre en un teatro. Lo que ocurre en un teatro pero no ocurre como siempre. Como se espera. Creadores que transitan ajenos a los límites y convenciones de las artes escénicas. Que son muchos. Los creadores, los límites y las convenciones. ${ }^{3}$

2 Teatro Raro es una de las líneas de programación cultural del Ayuntamiento de Madrid (https://ciudadistrito.es/) a raíz del relevo político de 2015, cuando el grupo conservador Partido Popular fue sustituido por el recién formado "Ahora Madrid" (integrado por distintas formaciones y agentes culturales de izquierdas). No es casualidad que dicho relevo, a nivel nacional formado también por partidos de derechas, valorara el que muchos de sus integrantes no sean políticos profesionales y apelara a la necesidad de reinventar los usos de la política.

${ }^{3}$ Extraído de la presentación del ciclo Teatro Raro en la programación de actividades culturales del Ayuntamiento de Madrid-CiudaDistrito: https://ciudadistrito.es/dejate-sorprender-con-el-teatro-raro/. 


\section{El arte como crítica institucional}

La disfuncionalidad del objeto artístico, por la cual este último escapa a la lógica de la producción material y su rentabilidad, queda en entredicho, hace que en alguna medida todo arte tenga algo de crítica hacia las instituciones que lo producen, lo explican y lo conservan, mostrando a fin de cuentas la rentabilidad de lo aparentemente no rentable. Junto a la lógica de la producción material conviven otras lógicas culturales, que, atendiendo a otras reglas, hacen que el arte pueda convertirse en uno de los campos de especulación preferidos por el capitalismo. Las instituciones no sólo validan un determinado enunciado histórico acerca del arte, señalando ciertos espacios artísticos, sino que también sancionan los usos adecuados del arte y educan al público en las formas de entenderlo y apreciarlo correctamente.

El arte no está conformado solamente por las obras producidas, sino que implica a un complejo sistema cultural sostenido por instituciones que lo sitúan en un lugar determinado. La crítica de estos ámbitos de legitimación artística, identificados con instituciones como los museos, teatros, centros de educación y de creación, así como con las universidades y otros ámbitos de formación, es parte de la propia historia y teoría del arte. Ya en los años treinta John Dewey, que dedicó tantas páginas a entender la política y la educación de forma menos normativa, abre su libro El arte como experiencia cuestionando la validez de los museos como marcos de exhibición de las obras, aludiendo a la economía de aislamiento y acumulación que sostienen estas instituciones:

Cuando un producto de arte alcanza una categoría clásica se aísla de algún modo de las condiciones humanas de las cuales obtuvo su existencia, y de las consecuencias humanas que engendra en la experiencia efectiva. [...] Cuando los objetos artísticos se separan tanto de las condiciones que los originan, como de su operación en la experiencia, se levanta un muro a su alrededor que vuelve opaca su significación general, de la cual trata la teoría estética (3).

No es difícil rastrear en Amateur los argumentos de Dewey en relación con la condición canónica de ciertas obras y contra el efecto de embalsamamiento que conlleva la propia institución. Arte, institución, mercado, producto, experiencia... el conflicto no es nuevo. En los años cincuenta y sesenta, con el crecimiento de la economía de consumo, la sociedad de masas y las industrias culturales, se extiende lo que historiadores como Benjamin Buchloh - siguiendo la estela de los conceptualismos-denominaron crítica institucional del arte ("El arte conceptual"). Más recientemente, a partir de los noventa y como respuesta a los efectos de la economía neoliberal en el campo cultural, esta línea 
crítica fue retomada por creadores y teóricos del arte (véase la plataforma de investigación en artes denominada Transform). ${ }^{4}$

El recorrido de la escultora brasileña Lygia Clark resulta significativo a este respecto. Su evolución en busca de nuevas formas de situar su obra en el espacio público, de ponerla en relación con la gente y colocarse ella misma en relación al mundo a través de su trabajo, supone una constante labor de reflexión sobre los límites y funcionamiento de la institución artística. Desde el movimiento neoconcreto hasta la etapa de los objetos relacionales - utilizados en las sesiones individuales de terapia que la artista realizó en su propia casa hacia el final de su carrera-, pasando por Bichos y sus trabajos con materiales blandos y ropas, Clark no dejó nunca de explorar formas distintas de rehacer la experiencia artística junto con el público. La teatralización del arte, que durante las vanguardias históricas se construye como una reinvención y un juego del artista con su identidad, en la segunda mitad de siglo estará motivada sobre todo por el deseo de atravesar los lugares oficiales del arte, haciendo visibles las condiciones de la producción artística con el fin de transformar sus formas de uso. Se trata de una dinámica de desplazamientos cuyo fin no es la llegada a un determinado punto, sino mantenerse en constante movimiento para evitar fijar el sentido de la obra y la experiencia a la que da lugar, porque como explicaba Clark:

En el preciso momento en que el artista digiere el objeto, es digerido por la sociedad que ya le encuentra un título y una ocupación burocrática: será así el ingeniero de los pasatiempos del futuro, actividad que en nada afecta el equilibrio de las estructuras sociales (cit. en Roznik parr. 4).

Esta podría ser otra cara de la argumentación de Dewey sobre el arte como objeto de museo. Si el filósofo se refería a esto ya en los años treinta desde el punto de vista de la teoría estética, es ahora una artista quien, unas décadas más tarde, expone el mismo problema desde el punto de vista de la experiencia del creador y su lugar dentro de las lógicas de la producción y del mercado. En definitiva, la finalidad de Rubén Ramos al tratar de sacar a la música antigua - e indirectamente al propio teatro- de los marcos de consumo que imponen unas normas determinadas, coincide con aquella intención. Las respectivas posiciones del filósofo, la artista conceptual y el creador escénico, coincidentes en cierto modo a pesar de la distancia que las separa, servirían en todo caso para dar respuesta a

4 Transform, ed. Producción cultural y prácticas instituyentes. Líneas de ruptura en la crítica institucional. Madrid: Traficantes de sueños, 2008. También en transform.eicpc.net. http://transform.eipcp.net/transversal/0808. Consultado el 20 de julio de 2017. 
una pregunta que, más recientemente, plantea Brian Holmes al comienzo de su ensayo sobre las nuevas formas de la crítica institucional:

¿Cuál es la lógica, la necesidad o el deseo que impulsa a cada vez más artistas a trabajar fuera de los límites de su propia disciplina, definida por nociones de reflexividad libre y estética pura, materializada en el circuito galería-revista-museo-colección y acechada por la memoria de la pintura y la escultura como géneros normativos? (203)

La crítica institucional no se ha desarrollado con suficiente fuerza en el ámbito teatral, a pesar de que las instituciones teatrales ocupan un importante espacio público y simbólico. Éstas están a menudo representadas por los teatros nacionales, esos edificios que constituyen referencias históricas importantes. Si las artes en general exigen un grado de institucionalidad para conformarse públicamente, en el caso del teatro la coraza institucional es aún mayor, debido a la función que éste ha tenido en muchos momentos de la historia en relación no sólo al desarrollo de los géneros literarios (en épocas en las que no había imprenta), sino también a la construcción de identidades nacionales y debates culturales que surgieron a partir del siglo XVIII en adelante.

La finalidad de este artículo es echar un vistazo al medio escénico, enfocándolo a través de esta inquietud en torno a la dimensión institucional que configura un espacio de creación artística y discutiendo el problema. Para ello se señalará comparativamente la relación entre el teatro y el museo como espacios simbólicos correspondientes a dos distintos tipos de instituciones artísticas que, sin embargo, han buscado en los últimos años espacios de confluencia. En segundo lugar, se considerarán algunos proyectos creativos que cuestionan los límites de la institución teatral, invitando a repensar su lugar como espacio práctico de discusión y acción pública.

La crítica institucional, a través del acontecimiento escénico, despliega una teatralidad que ya no afecta solamente a la obra sino también a la situación y el contexto donde ésta opera. La teatralidad de la obra deja así de circunscribirse a determinados lenguajes fijados por la tradición y comienza a corresponder al ejercicio de cuestionamiento de los marcos de legitimación artística que se busca desarrollar. Trasladando la pregunta de Holmes al medio escénico, quedaría formulada de este modo: ¿Cuál es la lógica, la necesidad o el deseo que impulsa a cada vez más actores y directores de teatro, coreógrafos, escenógrafos y bailarines a trabajar fuera de los límites de su propia disciplina, definida por nociones de reflexividad libre y estética pura, materializada en el circuito teatro-auditorio-centro_cultural-galería-calle y acechada por la memoria del teatro y la danza como géneros normativos?

A raíz del los años 2000, Holmes distingue una nueva etapa en las formas de crítica institucional guiada por la extra-disciplinariedad, la cual habría estado precedida por 
dos tendencias: la inter-disciplinariedad y la in-disciplinariedad. Estas últimas son fácilmente reconocibles en el medio escénico a partir de los años sesenta, por ejemplo, en la "contaminación" de lenguajes (teatro, danza, performance, video) y la disolución de sus fronteras, expresada en algunos casos a través de actitudes irreverentes - piénsese en la performance y el teatro físico- que buscaban la producción de nuevas subjetividades. Coincidiendo con otras voces críticas que han tomado como eje de sus reflexiones a las formas de producción artística — como Bojana Kunst (Artist at Work) -, Holmes insiste en que tales estrategias ya han sido actualmente identificadas, habiendo agotado entonces su capacidad crítica y quedando convertidas en productos culturales que se cierran sobre sí mismos (autorreflexividad). Es decir, la obra se conforma, en este caso, girando sobre sí misma y autoenvolviéndose, condicionada, por el marco en el que se presenta, a ser un producto artístico más.

Tal acoplamiento entre las obras y el medio cultural era calificado por Lygia Clark como ingeniería del entretenimiento. El alcance de esta clausura autorreflexiva -o, visto en positivo, la capacidad crítica que aún puedan conservar este tipo de disonancias y desplazamientos-, no es, sin embargo, algo que pueda medirse objetivamente. La pieza de Rubén Ramos citada arriba, por ejemplo, se acerca a la extradisciplinariedad en la medida en que utiliza el escenario como espacio de discusión y expresión de otro tipo de lenguaje artístico, pero no escapa al riesgo de la clausura autorreflexiva.

Más que como una etiqueta clasificatoria con una definición clara, resulta entonces preferible entender la "extradisciplinariedad" planteada por Holmes como una perspectiva metodológica. En todo caso, en este artículo adoptamos como punto de partida la necesidad expresada por dicho concepto de colocar al trabajo artístico -y más concretamente al trabajo escénico - en diálogo con otros espacios de investigación, conflictividad y conocimiento (la música en el caso de Amateur o la sanación en el caso de los objetos de Lygia Clark, por ejemplo). Es en este sentido que Holmes diferencia entre tropismo y reflexividad:

El término 'tropismo' expresa el deseo o la necesidad de girarse hacia otra cosa, hacia un campo o disciplina exteriores; mientras que la noción de reflexividad indica ahora un regreso crítico al punto de partida, un intento de transformar la disciplina inicial, acabar con su aislamiento, abrir nuevas posibilidades de expresión, análisis, cooperación y compromiso (205).

El desencuentro es la figura que voy a utilizar como gesto crítico y estético a lo largo de las siguientes páginas; no el desencuentro en sentido literal, sino ciertos umbrales de no-coincidencia entre el sitio oficial que se le confiere a una obra por el contexto al que está asignada, y el espacio estético y situación escénica que dicha obra logra producir. Se trata de un 
territorio de desplazamientos que voy a intentar mostrar con el valor de una figura estética con posibilidades críticas.

A pesar de las numerosas tendencias de teatro fuera de los teatros que vemos actualmente, como proyectos site-specific o intervenciones urbanas, los recintos artísticos convencionales (teatros, galerías, centros de arte o museos) siguen siendo los espacios que con mayor frecuencia albergan la producción artística. Éstos suponen a la vez un contexto y marco de trabajo específicos, que por lo general pasan desapercibos al haber quedado integrados y confundidos dentro de nuestro sentido común. Resulta obviamente normal que el teatro se haga en los teatros o el arte en las galerías; no obstante, dichos espacios no son meros continentes neutrales sino que se fueron configurando a través de una historia específica y determinado tipo de relaciones sociales. Cuestionar a la normalidad cultural y artística sostenida desde un horizonte institucional, permite recuperar para las prácticas de creación una cierta anormalidad que obliga a repensar su sentido en relación con su entorno.

\section{Instituciones artísticas y teatrales}

Las instituciones teatrales y las dedicadas a las artes visuales han abierto territorios de confluencia, como resultado de la creciente indefinición de los límites entre las prácticas artísticas en general y la necesidad de proyectarse hacia fuera para reactivar localmente los vínculos con las sociedades. La disolución estratégica de las fronteras no es un fin en sí mismo, sino un medio para resituar el trabajo artístico de modos distintos frente a los ámbitos públicos en los que se presenta. Es frecuente que museos y centros culturales de reciente creación, así como algunos de los ya tradicionales cuando son remodelados, prevean la convivencia entre formas de creación diversas. Artes visuales, danza, teatro, performance, intervenciones urbanas... pasan a formar parte de un paisaje común.

Sin embargo, las respectivas genealogías y casuísticas que han llegado a conformar a cada uno de estos espacios como buques insignia de los escaparates culturales de los estados, son bien distintas. La diferencia estriba esencialmente en la naturaleza de las obras artísticas que tradicionalmente han custodiado los museos, frente a la de aquellas que han custodiado los teatros; sus lógicas y necesidades diversas y sus respectivos roles como parte del patrimonio cultural. La fuerte dimensión patrimonial que tanto el teatro como el museo encierran, les confiere a ambas una tarea común: la correcta conservación, estudio y actualización de un pasado a través de las obras. Ahora bien, los modos de reactualizar dicho pasado artístico o la forma de construir y sostener tales relatos históricos situándolos en relación con un presente, difieren notablemente. 
A diferencia de lo que ocurría en las artes visuales, las instituciones escénicas (teatrales, dancísticas o musicales) han demandado siempre de algún tipo físico de interpretación para actualizar sus obras, a menudo conservadas y transmitidas como textos dramáticos en papel, coreografías o partituras musicales. En el caso de los museos, tradicionalmente se alzaba entre los objetos de arte y el público un dispositivo materializado en la arquitectura y disposición del propio museo o la galería; una mediación abstracta que implicaba una interpretación teórica pero no física.

Esto comenzó a cambiar, sin embargo, durante la segunda mitad del siglo xx, cuando el medio de las artes visuales se fue abriendo a un amplio abanico de tendencias en torno a la peformance, las artes de acción y las del cuerpo o del movimiento. Los museos se vieron obligados a introducir otro tipo de mediaciones interpretativas, como el cuerpo de los performers, los bailarines o - más recientemente - los "facilitadores", si bien, intentando conservar el estatus del resultado artístico como objeto de contemplación por parte del público.

Por otro lado, la actualización de la obra por parte del intérprete musical, actoral o coreográfico pone en juego un ámbito de posibilidades que ha sido objeto de una estricta vigilancia por parte de las instituciones. El tema de la libertad interpretativa versus la fidelidad a los textos dramáticos, partituras o condiciones históricas de representación —cuando se ha llegado a considerar que ahí radica la autenticidad de la obra y su verdadero valor artístico-, es uno de los conflictos que han definido la historia de estos medios. En las artes interpretativas, la conservación del patrimonio recae sobre unos cuerpos vivos que tradicionalmente han tenido que estar al servicio de un director, dramaturgo o coreógrafo que se responsabiliza de afinar el sentido de la interpretación. Pero a lo largo del siglo xx, los actores (incluso en el sentido más general de agentes sociales, más allá de los actores de teatro) van a cuestionar dicha relación de subordinación. La interpretación de la historia y la relación con el pasado se han adentrado, actualmente, en un terreno inestable que problematiza los relatos lineales y las lógicas causales.

Bajo cierta metáfora teatral, la historia se muestra como un escenario político que hace visibles unos nombres, acontecimientos e interpretaciones mientras deja otros en la sombra. Si tanto en los espacios artísticos como en la historia del arte se desarrolla un movimiento de desobjetualización, en los medios escénicos se implementa una tendencia paralela a la desactorización. Ni el objeto artístico ni los actores escénicos serán desechados definitivamente (al menos no ha sucedido aún), pero se ha inaugurado una dinámica de cuestionamiento en torno a los límites de la obra y la condición del actor (no sólo como mediación o continente físico, sino también como sujeto y potencia crítica de desestabilización). Y esta reflexión sobre los lugares de actuación ha implicado, desde luego, una revisión de los lugares de enunciación como espacios de legitimación. A final de cuentas, lo que se trastoca también es la posición del espectador y los modos de recepción de las 
obras - a favor de formas y ámbitos de relación más abiertos e inestables, en los que la responsabilidad de la interpretación pasa a ser compartida por todos los agentes que toman parte del evento escénico (tanto intérpretes físicos como ayudantes, técnicos, gestores y, por supuesto, el público en general)-.

De este modo, si los museos se teatralizan — no sólo en cuanto a la estética de las obras, sino, sobre todo, por la manera de actualizarlas y hacerlas públicas - recurriendo a menudo a la performance, los teatros se desteatralizan tomando distancia frente a sus ropajes y usos tradicionales para adoptar formas de teatralidad más contextuales, comparables en algunos casos a las desarrolladas recientemente en los museos. La tendencia a la abstracción espacial, compartida por teatros y museos, busca adelgazar la mediación interpretativa dando mayor protagonismo al público. Cubos blancos y espacios polivalentes tratan de crear una sensación de neutralidad, de espacio vacío, sin historia ni pasado, donde cada nueva obra puede recibirse con los mínimos condicionamientos.

Frente a esta asepsia expositiva, los proyectos de creación -como apuntaba Holmes en relación a la extradisciplinariedad- lanzan cabos hacia el mundo de afuera. A veces intentan hacer visible la historia y memoria detrás de esos espacios de exposición o representación, así como el rol esencial que los asistentes -identificados provisionalmente por un término tan abstracto como el de público- han jugado siempre en la configuración de tales dispositivos culturales. Como veremos a continuación, los teatros, a través de nuevas líneas curatoriales que han hecho posible otro tipo de proyectos de creación, hoy pueden adquirir también una dimensión expositiva. Y los espacios dedicados a las artes visuales, recíprocamente, se teatralizan dando lugar a espacios confluyentes en los cuales es posible repensar los límites y potencias de ambas instituciones.

Ahora bien, cerrar este apartado aquí podría generar falsas expectativas o no responder al estado actual de la cuestión. Es necesario observar que las inercias institucionales son fuertes: solamente en años muy recientes se ha extendido el interés por las artes escénicas en los museos como una perspectiva transversal, al tiempo que se han ido abriendo los formatos escénicos tradicionales - danza y teatro - a una diversidad de posibilidades que rebasan el marco de la escena. Es, sin embargo, en este último campo donde los recelos institucionales y el afán por conservar derechos adquiridos ofrecen mayores resistencias al proceso descrito de apertura y renuncia a lenguajes ya constituidos. El capital simbólico que reside en el cuerpo del actor y el riesgo que para las instituciones, la ortodoxia cultural y los intereses creados supone la emancipación de dichos cuerpos en relación a los textos y partituras que deben interpretar, explica el conservadurismo formal del teatro frente a otros ámbitos artísticos.

Cuando Chris Dercon tomó la dirección del teatro berlinés de la Volksbühne en 2018, los recelos no se hicieron esperar, transformados en algunos casos en movimientos de 
protestas. Que una institución que había estado dirigida por figuras históricas como Max Reinhardt, Heiner Müller y, más recientemente, Frank Castorf, pasase a quedar en manos de un prestigioso director de museos y espacios artísticos a nivel internacional (como la Tate Gallery de Londres en su última etapa) resultó cuando menos llamativo en los círculos teatrales. Una reacción comparable se vivió en Madrid a raíz del nombramiento del nuevo director de los espacios destinados al teatro dentro del complejo cultural y centro de creación artística Matadero. El proyecto de Mateo Feijóo para las Naves de Matadero generó una sonora polémica, alimentada por una carta dirigida al Ayuntamiento de Madrid - firmada por numerosos profesionales del medio teatral-, denunciando que esta ciudad "perdía un teatro" con toda la carga simbólica y demagógica que ellos veían en dicho gesto. A esto se respondió con una nueva carta - que contó, a su vez, con el apoyo de numerosos creadores del ámbito del teatro, la danza y las artes en general-, reclamando un reparto más equitativo de los recursos públicos (centrados hasta el momento en el subsidio a un sólo tipo de teatro). Los muros de la institución teatral, identificada con determinados modos de hacer y pensar el teatro, parecen no aguantar más el reto que arrojan nuevos tiempos, que impulsan un uso más diverso de los espacios públicos de creación escénica.

En Radical Museology, a través del estudio de tres museos -entre los que se cuenta el Museo Nacional y Centro de Arte "Reina Sofía", que no por casualidad en los últimos años ha sido abordado constantemente por diversos proyectos de investigación y tomado como escenario de varias obras teatrales, dancísticas y performances-, Claire Bishop analiza nuevas formas de convertir los museos en espacios verdaderamente contemporáneos. El libro puede invitarnos a trasladar la reflexión también al ámbito de las instituciones escénicas y preguntar qué es "contemporáneo" en los centros de teatro contemporáneo. Podría desarrollarse una investigación análoga que se enfoque en la transformación de algunos espacios teatrales en centros de creación abiertos a una diversidad de formas escénicas, como las citadas Naves de Matadero. Otro ejemplo podría hallarse en la gestión de Rodrigo García al frente del Teatro de Montpellier (perteneciente a la red nacional de teatros franceses), durante la cual el sitio pasó de llamarse Le Théâtre des Treize Vents - y de estar dedicado a un repertorio clásico y a un público de élite - a ser el "hTh" (Humain trop humain), asumiendo un giro radical en su programación y en la forma de pensar al teatro en relación a su entorno.

Menos traumática ha sido la relación entre la danza y el museo. Al no estar tan identificada con la palabra y el texto, aquélla ocupa un espacio simbólico y patrimonial diferente. La relación entre el museo y el ámbito expandido de la danza, articulado a partir de los años noventa en torno al concepto de coreografía, venía ya precedida - al igual que la relación museo-teatro- por el horizonte transversal abierto por la performance. La pregunta so- 
bre cómo meter en el museo a la danza (coreografía de movimientos) y qué lugar darle al cuerpo y a la acción dentro del espacio expositivo, desplegó un nuevo ámbito de reflexión cultural y artística. Tampoco dejó de implicar, nuevamente, el riesgo de provocar que tales acontecimientos quedaran reducidos a objetos de contemplación al servicio del potente marco de la galería o el museo (cuando en su concepción creativa aspiran a ser lo contrario: intentos de romper con los marcos habituales del trabajo artístico o dancístico).

Proyectos como 20 bailarines para el siglo $\mathrm{xX}$ de Boris Charmatz - también conocido como el "Museo de la danza"-, acogido en 2016 por el Museo Reina Sofía; o Una exposición coreografiada de Mathieu Copeland, que pasó por el Centro de Artes Dos de Mayo perteneciente a la Comunidad de Madrid - un espacio más joven que desde su apertura apostó por un diálogo horizontal entre prácticas y formatos artísticos distintos-, podrían ser buenos ejemplos de estos nuevos territorios contemporáneos de confluencia. Para la exposición a cargo de Copeland, que se acompañó de la publicación colectiva Coreografíar exposiciones, el comisario invitaba a nueve coreógrafos (entendiendo el concepto en su sentido más amplio) a proponer partituras de movimiento. El resultado fueron trabajos que integraron a creadores teatrales tan significativos en la escena contemporánea como Tim Etchells (director artístico de Forced Entertainment), interpretados en bucle durante los días que duró la exposición.

Las reacciones ante el riesgo de una probable musealización del lenguaje coreográfico no se han hecho esperar, a pesar de que las intenciones de estos creadores han sido justamente de ruptura ante los rígidos espacios y contextos de trabajo de la danza clásica y moderna. Véanse, por ejemplo, las preguntas que se plantea la coreógrafa Amalia Fernández en Expografía (2017), un proyecto que nace a raíz de su propia participación en Una exposición coreografiada:

una experimentación acerca de lo que ocurre cuando las artes escénicas, activadas por seres humanos, salen de los contextos teatrales a los contextos expositivos museísticos.

¿Cómo afecta a la obra viva la temporalidad del museo?

¿Hasta qué punto se convierte en una mezcla de coreografía y reality show?

¿Cómo afecta al performer ese marco diseñado para objetos inanimados?

¿Cómo se comporta el público cuando se da ese choque de formatos? ¿Qué se espera de él? ¿Cuál es la convención a la que debe responder? ${ }^{5}$

${ }^{5}$ Extraído del texto de presentación de la obra en el Teatro Pradillo: https://www.teatropradillo.com/expografial. 


\section{El desencuentro con los lugares de actuación}

Volviendo al terreno teatral, la primera directora fichada por la nueva Volkbühne de Chris Dercon fue Susanne Kennedy. Su llegada a la compañía estuvo precedida por diversos premios y un creciente reconocimiento que la llevó hasta el Theatertreffen de Berlín en 2014, donde su trabajo causó polémica con propuestas como Purgatory in Ingolstadt (2013), con texto de Marieluise Fleißer, o la más reciente ¿Por qué enloqueció el Sr. R.? (Warum läuft Herr R. Amok?, 2014), inspirada en la película homónima de Rainer Werner Fassbinder y Michael Fengler (1969). Ambas fueron realizadas con el Teatro de Cámara de Munich, del que Kennedy fue directora invitada hasta su desembarco en Berlín. Las preguntas de Amalia Fernández acerca de los efectos que el espacio expositivo y hábitos del museo pueden tener en la recepción del trabajo del performer, y más concretamente en la del intérprete coreográfico, son trasladadas en el trabajo de Kennedy a la figura del actor y a la dramaturgia teatral. La directora holandesa transforma el teatro en un ámbito visual con una dimensión de fuerte carácter físico y emocional, que se articula, sin embargo, como un medio sumido en un proceso de atrofia terminal. Es a través de la reducción de la acción, gestualidad, expresividad e interacción, que se genera un espacio donde el público se ve interpelado - incluido y excluido a partes iguales - como si fuera un actor más atrapado en un entorno social que lo deja reducido al estatus de un autómata.

Siguiendo un determinado procedimiento escénico (sello de marca en los trabajos de Kennedy), la directora pone en escena un mundo de autómatas resignados con el medio en el que se mueven: un universo visual de figuras detenidas, vacías, incapaces de reaccionar. Los diálogos están previamente grabados, los actores no hablan nunca en escena aunque a través de su presencia, actitud y una mínima gesticulación (por ello también altamente expresiva) parecería que sí lo hacen. Incidiendo en este mecanismo de desconexión, la grabación de los textos ha sido realizada deliberadamente con gente no profesional y el rostro de los actores se cubre con una máscara de látex. En el caso de ¿Por qué enloqueció el Sr. R.?, la trama queda sintetizada en una selección de conversaciones anecdóticas sacadas de una película que sintoniza bien con esa dimensión aparentemente intrascendental del día a día. Fassbinder, sin embargo, es recorrido por pasiones reducidas a momentos puntuales de locura, como el que sucede al final de la obra. La impresión que queda del acontecimiento - y de la que se hizo eco la crítica (Rüdiger Schaper, Der Tagesspiegel) - es que se asemeja a un mundo de zombis, personajes intercambiables, seres anónimos que asisten mudos al espectáculo anodino de sus vidas, situados al mismo nivel que las plantas que decoran algunas de las escenas o de las marionetas expuestas en un escaparate. Los actores pasan a ser presencias extrañas en una trama que no dominan, con la mirada fija por la máscara y una actitud bobalicona. 
La pieza se desarrolla en una especie de sótano recubierto de madera que hace pensar en el interior de un sauna: un espacio geométrico sumamente reducido, que sirve al mismo tiempo de casa, oficina, bar, colegio y consultorio médico; una urna asfixiante, vacía y extraña cuya madera y las plantas que alberga dan una "impresión de naturaleza", pero en la que se percibe al mismo tiempo una artificialidad semejante a la de un laboratorio humano. Desde el patio de butacas, el ámbito de actuación se recorta como un cubo de luz alargado y encerrado en cristal. Cada escena está marcada por la subida y bajada de un telón, lo que impone una cadencia lenta y uniforme como si se tratara de planos inconexos de una misma película. No sólo los personajes parecen ignorar qué pintan en medio de la trama que los envuelve, sino que los propios espectadores comienzan a preguntarse cuál es el sentido de todo eso. En el desenlace, el Sr. R., en un momento de locura, termina matando a su mujer, su hijo y a una amiga de la familia, golpeándolos con una enorme maceta. Incapaces de cualquier tipo de expresión afectiva, la presión acumulada termina saliendo en un brote de violencia convertido en un momento cómico que el público agradece con risas, evidenciando también su alivio. La escena última es un extraño broche en el que aparecen los técnicos del Teatro de Cámara de Múnich improvisando un baile con "Let it grow" de Eric Clapton, una suerte de celebración por parte de los subalternos festejando la incapacidad de los actores profesionales para hacerse cargo del propio teatro que han creado.

En una conversación pública a raíz de la presentación de la obra en la Mostra Internacional de Teatro (MIT) de São Paulo en 2016, la directora explicaba que ella veía a los actores y espectadores del mismo lado de la escena, asistiendo impotentes a un drama - teatral- que los excluye, una maquinaria social y cultural que ejecuta sus funciones sin tener en cuenta a sus usuarios. Ante el desplazamiento del actor, todo el espacio es acaparado por dicho mecanismo, frente al que tanto el propio intérprete como el público parecen estar sometidos. La cualidad visual de la propuesta la acerca a una instalación con actores, lo que subraya la autonomía del espectáculo, que podría llegar a realizarse sin la presencia de espectadores o con un público que entrase y saliese de la sala a capricho.

Si Kennedy lleva al límite el artificio del teatro atrofiando deliberadamente la acción dramática, el artista libanés Rabih Mroué realiza una operación contraria, escapando del teatro por el lado de la no-ficción: su obra se convierte en una conferencia o exposición. La teatralidad no se difumina, sino que se hace recaer en el distanciamiento frente a los marcos de legitimación de la historia presentada, arrojando una interrogante sobre la veracidad de las imágenes y documentos que se utilizan. Trasladado al ámbito teatral, este mecanismo se convierte en una pregunta acerca del tipo de situación generada a través de la obra/conferencia. El público - que tanto en el caso de la obra de Kennedy como en ésta, esperaría encontrarse con alguna suerte de representación-, siente una sensación de desencuentro de la que tiene que hacerse cargo (un desencuentro que implica tanto al 
propio espacio como a la institución que lo enmarca). El desplazamiento de la representación, frecuentemente causante de actitudes de rechazo, suscita sin embargo, en este caso, un espacio y tiempo suspendidos, un momento abierto a la reflexión sobre los mecanismos que sostienen la construcción misma de los relatos (el del mártir, el de la guerra o el de la historia), y, por extensión, sobre la propia institución teatral y los modos de construir las representaciones. Pues el teatro, como dispositivo de representaciones, al mismo tiempo se superpone y es utilizado por otros tipos de dispositivos visuales y políticos, económicos y morales. Donde antes había una trama dramática, una historia, unos personajes y unas acciones para ser leídas, ahora hay un público preguntándose por la intención última de la presentación a la que asiste: ¿Teatro?, ¿conferencia?, ¿investigación artística?, ¿denuncia política?, ¿autobiografía?

El formato de conferencia al que recurre Mroué reiteradamente, muestra abiertamente los perfiles del desencuentro señalado. Lejos de la teatralidad dramática, es en cada caso el propio artista (en La revolución pixelada (2012), el propio director/actor; en Tan poco tiempo (2017), también él, acompañado de Lina Majdalanie; en Cabalgando nubes (2013), su hermano, Yasser Mroué) quien sostiene el cara a cara con el público. Presencias escénicamente neutras que remiten a algún tipo de ausencia, cuerpos sin apariencia de actores y en un registro que hace pensar más en una exposición académica que en una obra de teatro (como explicaba el mismo director en la misma edición del 2016 de la MIT, en la que se presentaron los trabajos aquí citados).

Aunque la idea de "conferencia performativa" es utilizada explícitamente sólo como subtítulo de La revolución pixelada (con la intención de evitar que la obra pudiera recibirse como un trabajo teatral), ese modo expositivo también característico de la obra de Kennedy, aunque con una elaboración teatral muy distinta, atraviesa toda la poética Mroué. La teatralidad de su trabajo radica, justa y paradójicamente, en ofrecerse negándose como teatro, sin dejar por ello de buscar presentarse en espacios teatrales dentro de centros culturales y festivales. Si el mismo producto fuera presentado, por ejemplo, en el aula de una universidad como parte de un congreso académico sobre historia política de Oriente Medio (el espacio que aparentemente le correspondería), su sentido variaría sustancialmente (tal como sucedería con la pieza de Rubén Ramos si se pusiera en un auditorio para conciertos). Es así la propia ausencia de teatralidad la que se hace sentir como otro tipo de teatralidad, articulándose en cada caso una relación de conflicto con los marcos culturales en los que operan estas obras. La impresión de cercanía con el público, sin la mediación de una estructura dramática, se convierte en un gesto formal que expresa una intención de encuentro e intercambio que, sin embargo, no llega a darse más allá del efecto estético producido por la obra.

Este juego de desplazamiento hacia lo real se refleja en todos los niveles; las imágenes, relatos o recuerdos - cuyo análisis detenido y cuidadosa exposición son el objeto de estos 
trabajos - expresan su cualidad escénica en tanto que son construcciones elaboradas desde un presente que se comparte con el público. Este último se (des)encuentra con un "actor" cuya interpretación consiste en una actitud de no-actuación mantenida desde el principio hasta el final, en un tono contenido y neutro al que contribuye la frontalidad con que se presenta. Desde un punto de vista de la pragmática, en comunicación, se despliega un tiempo entre paréntesis, suspendido, sostenido por un deseo de hacer visible una situación pública de discusión, reflexión y preguntas. Dichas preguntas quedan girando en la cabeza de los espectadores, la obra no intenta responderlas, sino hacerlas palpables tanto intelectualmente como a nivel sensible.

El teatro se convierte para Mroué en "una plataforma para compartir ideas y preguntas con otras personas. Es como un viaje en proceso que no tiene objetivo. [...] Es apenas el placer de pensar sobre el ser humano" ("Reconstruindo fragmentos", 41). Expuestas las interrogantes como resultado de minuciosos análisis acerca de cómo se producen las imágenes, cómo las recibimos y funcionan en la memoria, dichas preguntas no se limitan al plano material, sino que suscitan reflexiones sobre cuestiones básicas (identidad, guerra, violencia) y sobre el modo en que éstas se cuentan a través de las imágenes. El teatro de Mroué es una compleja maquinaria para pensar en voz alta y frente al público.

Tanto Kennedy como el artista libanés hacen un teatro que asume su propia incapacidad para llegar a algún tipo de respuesta o comunión con el público - más que en instantes particulares, como el cierre musical de la historia del Sr. R. o la identificación afectiva que se suscita con el actor de Cabalgando nubes, especialmente hacia el final de la interpretación musical-. Son poéticas que juegan con la potencia intelectual de la maquinaria teatral y se apoyan en presencias y acciones bien definidas, pero donde los cuerpos pierden su capacidad de acción en beneficio de una reflexión colectiva. El desencuentro intelectual se articula por medio de un espacio sensible desde el que se plantea una discusión sin resolver, que, en todo, caso queda pendiente para el público.

Este enfoque va un paso más allá en los proyectos del colectivo mexicano Teatro Ojo, en los que la delimitación del espacio entre actores y público se diluye porque escenario y platea pasan a ser funciones que se superponen en un mismo espacio (no ya un teatro, por lo general, sino cualquier otro entorno público con una memoria y una historia que rescatar). A partir de un proyecto de trabajo en el edificio Chihuahua en la plaza de Tlatelolco, S.R.E. Visitas guiadas (2007), Teatro Ojo descubre la riqueza teatral que esconden los espacios comunes y la posibilidad de arrojar sobre ellos una mirada escénica que saque a la luz estratos invisibles. A pesar de ello, en Lo que viene (2012) el grupo vuelve a un teatro, mas no para representar historias ajenas, sino para revisar las historias propias que le han ocurrido en otro tipo de espacios que no permiten el tipo de intercambio público propiciado por un teatro. 
El proceso creativo de este último montaje coincidió con los últimos meses del gobierno de Felipe Calderón, cuyo sexenio fue un periodo durante el cual México resintió un dramático aumento de la violencia por el narcotráfico. El teatro El Galeón, donde se realizó la obra, está dentro del complejo cultural del INBA (Instituto Nacional de Bellas Artes), situado a su vez a un lado del Memorial para las Víctimas de la Violencia, un polémico proyecto impulsado por el propio Calderón. La pregunta fue qué hacer, o mejor dicho, cómo utilizar una institución pública (un teatro del Estado pagado con el dinero de todos los ciudadanos) para hablar de lo que estaba pasando en ese momento en la vida pública de México. "Lo primero que pensamos - cuenta Héctor Bourges, miembro de Teatro Ojo - fue detenernos, interrumpir inercias, dar un tiempo y un lugar para mirarnos, recordarnos. Vaciar y descrear. Decidimos abrir - ocupar- el espacio escénico para hablar de eso que nos estaba pasando" ("Entrevista a Teatro Ojo", parr. 16). En Lo que viene, el teatro se abría al público ocho horas diarias, acoplándose más a los patrones de un museo o galería de arte que a los horarios normales de las funciones teatrales o a los usos institucionalizados de este tipo de espacios. Al quedar dispuesto como un lugar para recordar lo que otros ámbitos igualmente públicos han estado callando, el teatro comenzó a cumplir durante la temporada una función pública por excelencia. La gente encontraba al entrar una colección de diarios (los correspondientes a cada uno de los días del gobierno de Calderón), además de una serie de preguntas personales sobre las preocupaciones y sueños de cada "espectador", las cuales podían ser respondidas en voz alta a través de los micrófonos situados entre las notas de prensa. La obra iba construyendo así lo que ellos denominaron una "sismografía íntima", historias de los pequeños temblores que nos atraviesan todos los días.

Las instituciones tienen una función doble: se espera, por un lado, que sean capaces de resguardar un patrimonio (un pasado que hay que conservar), y, por el otro, que sirvan a la vida común del presente, en relación a la cual hay que situar dicho pasado. El desequilibrio entre estas fuerzas a favor del pasado las convierte en estructuras conservadoras que tienden a reafirmarse sobre sí mismas, sobre lo ya instituido (valores, formas, mitos y ritos ya construidos). Para recuperar lo que etimológicamente se espera de una institución, ¡su capacidad de instituir!, es necesario un trabajo previo de desinstitución y oposición a las inercias, o como decía Héctor Bourges: un tiempo para parar y mirar alrededor, un tiempo para preguntarnos. Ocupar de una forma crítica los espacios de producción, ocupar los teatros, centros culturales, auditorios y salas de exposiciones, implica hacer un uso disfuncional de esos espacios, utilizarlos - al tiempo que se inutilizan para los usos ya previstoscon el objetivo de abrir otras formas de circulación del capital, del arte y el conocimiento; de las actitudes y los afectos.

Precisamente eso es lo que hacen las obras que hasta aquí hemos venido revisando: proponen distintas formas de ocupar esos espacios de representación llamados teatros, 
con el fin de provocar reflexiones acerca de los modos de desinstituirlos e instituirlos con usos renovados. Tales estrategias son capaces de afinar la conciencia del tipo de espacio al que asistimos cuando participamos de un evento escénico, así como de las normas implicadas en ellos, devolviendo a estos ámbitos la posibilidad de convertirse en lugares de verdadero uso público. Sólo así logran admitirse otros modos, generando tiempos de suspensión y desencuentro que abran la posibilidad de repensar lo que estamos haciendo en estos sistemas de representaciones.

\section{El teatro como forma de descolonización: lugares de habla / lugares de acción}

La edición de la MIT en la que coincidieron estos trabajos de Susanne Kennedy y Rabih Mroué, tenía como ejes transversales los lugares del habla y la descolonización, dos temas que responden también al trabajo de Teatro Ojo o a la propuesta de Rubén Ramos. Aunque son asuntos distintos, no resulta difícil encontrar la relación entre ambos. Los lugares de legitimación de la palabra se convierten fácilmente en mecanismos de poder que históricamente han contribuido a sostener los procesos de colonización. No en vano, el teatro es una institución que desde sus orígenes modernos ha funcionado como un fiel aliado en la construcción de las identidades nacionales y de los modos de colonización cultural que impulsaron los procesos de expansión de naciones poderosas. A lo largo del siglo xx, este dispositivo de construcción de representaciones ha ido perdiendo las señas de identidad locales para hacerse más abstracto y más fácilmente exportable, como ocurrió también con los museos.

La reinvención de los lugares de actuación que hemos ejemplificado mediante las obras descritas, va unida a un proceso de reflexión acerca de las formas de construcción de los relatos y sus potencias críticas. No es suficiente con hacer como si no se actuara, se necesita tomar conciencia de los elementos de poder que sostienen a un dispositivo de creación (espacio cultural o institución artística), para plantear de forma eficaz la mejor estrategia de ocupación - para interrumpir sus inercias y abrir tiempos de suspensión, desde los que sería posible repensar otras posibilidades al ocupar dichos espacios en relación con el pasado que ellos inscriben-.

La misión en fragmentos: 12 escenas de descolonización en legítima defensa, dirigida por Eugênio Lima, fue una de las producciones del propio MIT en la misma edición de 2016. Consistió en una adaptación del texto inacabado La misión de Heiner Müller, interpretado por un colectivo numeroso de intérpretes negros amateurs que se habían juntado especialmente para este proyecto: Legítima Defensa. La propuesta retoma la discusión so- 
bre la posibilidad de la revolución tal y como se desarrolla en el texto de Müller (a partir de la experiencia jamaiquina), para cruzarla con el imaginario del quilombo en tanto que espacio de baile, resistencia y organización desarrollado en la cultura brasileña como estrategia de defensa por parte de los esclavos.

A pesar de la potencia física y colectiva de la obra, expresada por medio de bailes y cantos corales, su desarrollo formal termina sometiéndose al texto dramático y a la necesidad de representarlo. Hay un momento hacia el final en el que los actores invaden el espacio de las butacas para cuestionar la legitimidad del poder blanco, de la historia e, indirectamente, del tipo de teatro que se está haciendo, pero la acción queda como un tímido intento, dentro de una propuesta dramática que no consigue darle a la cualidad física y memoria colectiva de los intérpretes una dimensión crítica eficaz. Estos últimos no llegan a habitar el imponente espacio del auditorio Niemeyer en el que trabajan, a apropiarse de él imponiendo unas nuevas reglas de construcción u otras formas de estar y presentarse frente al público. La misión queda en un intento más de oposición a una historia de poder cuya materialización más inmediata, en ese momento, es la propia historia del teatro como legitimación de unas formas predeterminadas de habla y actuación.

Sin embargo, al final de la obra se eleva la pared del fondo del escenario, dejando ver el parque de Ibirapuera con sus árboles y zonas verdes en medio de la noche. Por esa enorme ventana mágica que conecta con la realidad exterior, comienza a entrar una multitud de gente, todos negros, que invaden el escenario para unirse a los intérpretes en un estallido de fiesta. Ese momento impresionante hace pensar en las posibilidades de un teatro cuyo punto de partida sea la suspensión de las propias reglas del teatro, un teatro que se apoye en la teatralidad en sentido amplio - no en la tradición dramática ni en las formas escénicas ya constituidas, sino en las personas y sus lugares, en la memoria y sus relatos-.

La pregunta que arroja esta puesta de La misión es cómo hacer creíble tal quilombo teatralmente, cómo darle realidad escénica a ese acto de ocupación, cómo sostenerlo en un espacio de la magnitud del auditorio Niemeyer (un tipo de construcción de los años 50 característico del arquitecto brasileño). La abstracción del espacio de la que ha dado buena muestra la arquitectura moderna, ha ido en paralelo al crecimiento de su poder simbólico, un poder que se ha proyectado también a las instituciones dedicadas a la cultura. Dicho proceso de abstracción, como ya estudió Henri Lefebvre en los años sesenta, es el que sostiene la lógica económica que a menudo regula la administración de los espacios públicos y, de forma más general, de lo público.

"Lo público" deja de ser un bien común cuya lógica esté en función del uso cotidiano y su apropiación por parte de quienes lo transitan, para convertirse en una abstracción, resultado de una calculada operación de medidas políticas e intereses financieros que dejan fuera de juego a sus usuarios. Estos pasan a ser actores de una obra que no han escrito, tal 
como terminaba ocurriendo en La misión; figurantes de una maqueta diseñada a una escala que les supera. El resultado sería distinto si la obra se realizara en otro tipo de espacios - no teatrales - y ante un público que no fuera el característico de un festival internacional de teatro, como la MIT. En ámbitos marginales y ante comunidades no familiarizadas con la institución teatral, que en principio es el destino final de este proyecto, el sostenimiento dramático de la fábula de Müller podría acaso ser entendido de otro modo.

Convertidos en objeto de especulación, calles, plazas y parques, así como teatros y otros edificios patrimoniales, suelen pensarse hoy en día a partir de su valor de cambio (ya se trate de capital material o inmaterial) antes que de su valor de uso. ¿No se consideran los teatros espacios simbólicos por excelencia, valorados más por lo que tienen de promesa cultural que por el uso que se hace de ellos? ¿En qué medida los teatros oficiales, convertidos a menudo en construcciones históricas con un pasado y una carga cultural bien identificados, continúan funcionando como formas de colonización cultural? ¿De qué capital simbólico hace ostentación la imponente geometría del auditorio Niemeyer y de qué tipo de capital humano nos está hablando La misión? ¿No sería más sensato renunciar a ese fabuloso escenario - o en todo caso desviar su uso, clausurar la escena, plantear la obra en los alrededores (por fuera del edificio) - para conquistar momentáneamente, hacia el final de la obra, ese núcleo de poder sin rostro que es la escena del capital financiero y blanco, tan estrechamente vinculada a esta arquitectura?

Aunque esta última pregunta podría radicalizarse aún más para sopesar si este tipo de espacios teatrales son realmente los que queremos conquistar, o si los espacios verdaderos de actuación están más bien en otros lugares de la ciudad. ¿Siguen siendo los teatros históricos y espacios institucionales de la cultura, lugares válidos para pensar y situarse en el mundo? La respuesta debería ser afirmativa, puesto que son estructuras sostenidas por el dinero público que deben cumplir por lo tanto una función pública; pero esta respuesta está condicionada a la necesidad de reflexionar sobre cuál es la función pública que debe cumplir hoy el teatro. A todas estas preguntas tratan de responder proyectos de programación en teatros y centros de arte como los apuntados al comienzo de este artículo.

\section{Conclusión}

El teatro es un lugar de habla cuyo valor simbólico le confiere cierta fuerza de legitimación, donde este hablar es además - y al mismo tiempo - una forma de acción, un modo de actuar y situarse en público, una posible vía para intervenir en un espacio social e institucional. Trastocar los lugares de habla implica transformar las formas de actuación y el lugar de los actores, mediante desplazamientos que ofrecen la posibilidad de generar espacios de 
suspensión desde los cuales es posible recuperar el pasado (artístico, musical, teatral y/o político) de modo que nos interrogue y nos mueva. De eso nos hablan las obras revisadas hasta aquí.

En Amateur se utilizaba el teatro para denunciar la rigidez y elitismo de los modos que la música clásica, como institución, había fijado para relacionarse con ella. Al mismo tiempo que se desarrollaba dicha reflexión, la puesta en escena se situaba en el escenario teatral de una forma inédita, reivindicando la figura del aficionado. El acto de tocar el piano se convertía en un gesto y una acción; un gesto que se dibuja frente al horizonte institucional de la música y una práctica sostenida escénicamente. Hacer y decir se solapaban, pues, como dos caras de una misma acción.

En las obras revisadas de Kennedy, Mroué y Teatro Ojo, de manera semejante, el teatro se transformaba en un espacio de reflexión colectiva con una cualidad expositiva que acercaba estos trabajos al mundo de las artes visuales, sin que ninguno de ellos renunciara a una teatralidad propia y disruptiva. La representación no constituía una finalidad para ninguno de ellos, sino el intento de usar y proyectar el espacio de actuación, y con ello la posibilidad de poner a la acción en relación con el público, generando un distanciamiento crítico con respecto al entorno cultural que organiza tales espacios. En los trabajos de Ramos y Mroué, es la apelación directa al público la que despliega dicho ámbito de reflexión conjunta. En la obra de Kennedy, por su parte, es la avería de la representación la que la convierte en un horizonte de contemplación que se extiende a lo largo de un tiempo que parece no avanzar, y que se proyecta en el público en forma de preguntas sobre la posibilidad misma de la acción. Pero es en el proyecto de Teatro Ojo donde esta apertura de un espacio de encuentro y desencuentro con nosotros mismos a través del pasado, se construye de forma más horizontal y abierta. Aquí ya no hay más actor que el propio público, enfrentado con su propia memoria, imágenes y representaciones.

En Una misión, contrastantemente, la construcción de la representación sigue estando, en primer y último lugar, como un plano sin resolver, al igual que la propia pregunta por la revolución que se plantea. La puesta en escena no consigue abrir una distancia frente a su horizonte de representación, el cual hace sentir sus reglas con la legitimidad que parece conferirle la potencia espacial del tipo de edificio en el que el montaje tuvo lugar, imponiendo unos modos históricos de enunciación ya identificados por la tradición teatral. Son definitivamente las propuestas de Ramos, Mroué y Teatro Ojo las que, de forma más clara, responden al deseo de extradisciplinariedad al que se refería Holmes.

Por otra parte, y al igual que muchas otras propuestas recientes para llevar la performance o la danza al museo, el trabajo de Kennedy corre el riesgo de quedar en un ejercicio de autorreflexión estética, tornándose un producto artístico demasiado asimilable en los espacios donde pretendía insertarse de manera innovadora. El caso de Una misión es dis- 
tinto en tanto no tiene una voluntad autorreflexiva, pero, reiterando, no consigue tampoco romper el marco de la obra dramática para proponer un nuevo lugar de encuentro y desencuentro susceptible de permitirnos repensar con cierta eficacia la posibilidad, si no ya de la revolución, al menos de la acción a través de la escena.

Aunque el único de los trabajos aquí citados que recupera explícitamente a la figura del aficionado es Amateur, todos ellos incorporan de forma diversa ese lugar como umbral de desestabilización y renovación de los usos institucionalizados del teatro y, en general, de las artes. Kennedy saca a los técnicos al final de la obra para hacer una coreografía casera; Mroué invita a su hermano, aún sin presentarlo como tal, para compartir con el público su propia memoria personal; Legítima Defensa es un grupo integrado por aficionados, aunque resulte evidente que en su entendimiento de la actuación miran hacia un horizonte de profesionalización teatral. Pero es nuevamente el trabajo de Teatro Ojo, que pone todo el tiempo y espacio del escenario a completa disposición de los espectadores, el que más radicalmente se ocupa de señalar la condición de aficionados que tenemos todos en casi todos los ámbitos de la vida, así como la necesidad de retomar ese ámbito indiferenciado que es el espacio común, como lugar de posibilidad para repensar la situación en la que nos encontramos.

Entender al teatro como un lugar de encuentro es uno de los mitos a los que suele recurrirse para imbuir de un sentido público y abierto cualquier evento cultural que no se quiera plantear de forma jerarquizada o vertical. Es en esta perspectiva donde han confluido, por cierto, el teatro y las artes visuales. La idea es que la actividad y - en su caso- la obra generen un ámbito de relación y transformación del entorno. El discurso del encuentro remite a unos orígenes desde los que se supone posible volver a pensar un rito artístico como lo es el teatro - que al igual que cualquier otro acto cultural está en permanente riesgo de perder su capacidad crítica e instituyente- para convertirse en un producto de consumo más - como argumentaba Lygia Clark- Pero la modernidad no nace de un mito, sino de la ruptura de mitos, o en palabras de Jean-Luc Nancy, de la suspensión del mito o de la representación y las identidades (La communauté désoeuvrée). Así pues, convocar al desencuentro es también necesario en la medida en que éste es la herramienta que permite sostener un estadio colectivo de suspensión, abriéndolo a otras formas prácticas de discusión del pasado. ¡No hay encuentro entre los individuos sin la posibilidad de desencuentro con las propias instituciones que custodian el pasado común de prácticas, lenguajes y valores! Solamente de este umbral de inestabilidades respecto al pasado surge la posibilidad de que las instituciones recuperen su capacidad instituyente, más allá de su función de administrar lo ya instituido. 


\section{Bibliografía}

Bishop, Claire. Radical Museology, or What's "Contemporary" in Museums of Contemporary Art? Londres: Koenig Books, 2013.

Buchloh, Benjamin. "El arte conceptual de 1962 a 1969: de la estética de la administración a la crítica de las instituciones". Formalismo e historicidad. Modelos y métodos en el arte del siglo XX. Trads. Carolina del Olmo y César Renduelles. Madrid: Akal, 2004, pp. 167-200.

Cartografías. MITsp. Revista de Artes Cênicas, núm. 4, 2017.

CiudaDistrito. "Programación cultural del Ayuntamiento de Madrid". CiudaDistrito. Ayuntamiento de Madrid, en línea. Consultado el 15 de noviembre de 2017.

Copeland, Mathieu. Coreografiar exposiciones. Madrid: Centro de Artes Dos de Mayo, 2017.

Dewey, John. El arte como experiencia. Trad., ed. y pról. Jordi Claramonte. Barcelona: Paidós, 2008.

Fernández, Amalia y Anto Rodríguez. Expografía. 2017-2018. Teatro Pradillo, Madrid, 2017.

Holmes, Brian. "Investigaciones extradisciplinares. Hacia una nueva crítica de las instituciones". Producción cultural y prácticas instituyentes. Líneas de ruptura en la crítica institucional, Boris Buden, et al. Madrid: Traficantes de sueños, 2008, pp. 203-215.

Kennedy, Susanne. Warum läuft Herr R. Amok?, Rainer Werner Fassbinder y Michael Fengler. 2014-2015. Münchener Kammerspiele, München, 2014.

Kunst, Bojana. Artist at Work. Proximity between Art and Capitalism. Londres y Nueva York: Zero Books, 2015.

Lefebvre, Henri. La producción del espacio. Trad. Emilio Martínez Gutiérrez. Madrid: Capitán Swing, 2013.

Lima, Eugênio. A missão em fragmentos: 12 cenas de descolonição em legítima defesa, Heiner Müller / Claudia Shapira. Legítima Defensa. 2016-2017. Mostra Internacional de Teatro, Auditório Ibirapuera - Oscar Niemeyer, São Paulo, 2017.

Mroué, Rabih. "Reconstruindo fragmentos: Rabih Mroué em Cavalgando nuvens". Entrevista con Cis Bierinickx. Cartografías. MITsp. Revista de Artes Cênicas, núm. 4, 2017, pp. 38-41.

Mroué, Rabih. Riding on a Cloud. 2016-2017. Münchner Kammerspiele, München, 2017.

Mroué, Rabih. Such Little Time. 2016-2017. Theater am Ufer, Berlin, 2016.

Mroué, Rabih. Pixelated Revolution. 2012. Documenta 13, Kassel, 2012.

Nancy, Jean-Luc. La communauté désoeuvrée. París: Christian Bourgois, 1983.

Ramos, Rubén. Goldberg Amateur. 2017-2018. Festival tNT, Piano Bar Reina Victòria, Terrasa, Barcelona, 2017. 
Ramos, Rubén. Gibbons Amateur. 2016-2017. Espacio Nyam Nyam, Barcelona, 2016.

Real Academia Española. "Institución". Diccionario de la lengua española. En línea. Consultado el 15 de noviembre de 2017.

Roznik, Suely. "La memoria del cuerpo contamina el museo". Instituto Europeo para Políticas Culturales Progresistas, núm. 1, 2007, en línea. Consultado el 21 de enero de 2018.

Schaper, Rüdiger. “Zeit der Zombies”. Der Tagesspiegel, 5 marzo de 2015, en línea. Consultado el 13 de julio de 2017.

Teatro Ojo. "Entrevista a Teatro Ojo". Entrevista con Gabriel Yépez. Archivo Virtual de Artes Escénicas, 26 de junio de 2016, en línea. Consultado el 21 de enero de 2018.

Teatro Ojo. Lo que viene, Héctor Bourges. Teatro Ojo. 2012-2013. Teatro El Galéon, México, 2012.

Teatro Ojo. S.R.E. Visitas guiadas, Héctor Bourges. Teatro Ojo. 2007-2008. Universidad Nacional Autónoma de México, Secretaría de Relaciones Internacionales, México, 2007. 


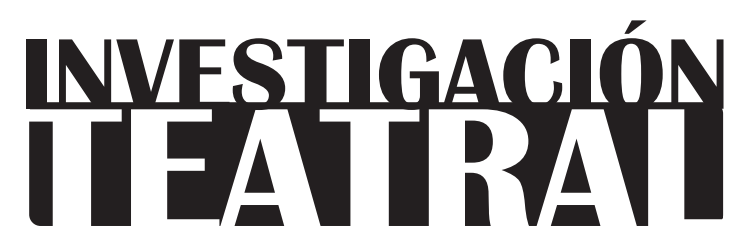

Revista de artes escénicas y performatividad

Vol. 9, Núm. 13

abril-septiembre 2018

Segunda época

ISSN impreso: 1665-8728

ISSN electrónico: 2594-0953

Universidad Veracruzana

\title{
Soberanía estallada: Memorias de Malvinas en Campo minado de Lola Arias
}

\author{
Verónica Perera*
}

\footnotetext{
* Departamento de Humanidades y Artes, Universidad Nacional de Avellaneda, Buenos Aires, Argentina.

e-mail:veronic.perera@gmail.com
}

Recibido: 01 de junio de 2017

Aceptado: 28 de noviembre de 2017 


\title{
Soberanía estallada: Memorias de Malvinas en Campo minado de Lola Arias
}

\section{Resumen}

El trigésimo aniversario de la guerra de Malvinas en el 2012 apareció como huella del pasado y fue recuperado en Argentina por la imaginación de una generación joven de dramaturgos y dramaturgas. Según Rosana Guber, este conflicto bélico operó históricamente como metáfora de la nación; sin embargo, el presente artículo argumenta que la obra Campo minado de Lola Arias subvierte esa metáfora. Asimismo, propone que esta obra estrenada en Brighton, Inglaterra, en mayo del 2016 y seis meses más tarde en Buenos Aires, descentra la noción de comunidad nacional, pues, mediante la actuación de seis excombatientes (tres argentinos, dos ingleses y un gurkha) y una historia basada en sus testimonios, narra el conflicto bélico sin tonos épicos y explora la cuestión de la soberanía nacional, aunque sin silenciar sus efectos sobre los cuerpos en la guerra. Finalmente, sugiere que la obra de Arias crea un espacio plurinacional y multilingüe, donde surgen nuevas imágenes y memorias sobre la guerra de Malvinas, atravesadas hoy por la experiencia común, pero también por el disenso y el conflicto entre los enemigos de entonces.

Palabras Clave: teatro documental, Lola Arias, Malvinas, Londres, Buenos Aires.

\section{Bursted Sovereignty: Falklands Memories in Campo minado (Minefield) by Lola Arias}

\begin{abstract}
The thirtieth anniversary of Malvinas (Falklands) War in 2012 became a trace of the past, recovered by a young generation of playwrights. According to Rosana Guber, that war has worked as a metaphor of the nation, but this paper argues that Campo minado (Minefield) by Lola Arias subverts that metaphor. The play was premiered in Brighton, England, on May 2016 and six months later in Buenos Aires. It is based on veterans' testimonies who actually take part in the show (three Argentineans, two English, one Gurkha) and by these means the play achieves to decenter the notion of national community. The article discusses how Minefield narrates the war without epic tones and explores the question of national sovereignty, but without silencing its effects on the bodies at war. Finally, the paper suggests that Arias' play creates a plurinational and multilingual space from where new images and new memories of Malvinas emerge. These images and memories are permeated with the common experience of the enemies at that time, but also with the conflict and dissent between them.
\end{abstract}

Keywords: documentary theater, Lola Arias, Malvinas, Falklands, London, Buenos Aires. 


\section{Soberanía estallada: Memorias de Malvinas en Campo minado de Lola Arias}

$\mathrm{E}$ trigésimo aniversario de la guerra de Malvinas en el 2012 apareció como huella del pasado - usando la expresión de Maurice Halbwach-, recuperada en Argentina no solo por la gestión diplomática y por organizaciones militantes de excombatientes, sino también por la imaginación de una generación joven de dramaturgas y dramaturgos. Treinta años después, el teatro independiente se hizo eco del teatro de operaciones militares de 1982 y se adaptaron ficciones literarias fundantes sobre la guerra, como Los Pichiciegos de Rodolfo Fogwill (1983) o Las Islas de Carlos Gamerro (1996). ${ }^{1}$

Campo Minado de Lola Arias es también un producto de ese contexto memorial. Esta puesta en escena fue encargada por dos festivales de teatro en Inglaterra, y luego de tres años de trabajo en Buenos Aires y en Londres, se presentó primero en el Festival de Brighton, el 28 de mayo de 2016, y casi seis meses más tarde en el Centro de Artes Experimentales de la Universidad Nacional de General San Martín en Buenos Aires.

La obra de Arias no inaugura el teatro documental sobre Malvinas. Cuatro años antes, por ejemplo, Julio Cardoso había escrito y codirigido Islas de la Memoria. Historias de guerra en la posguerra, desde el Observatorio Malvinas de la Universidad Nacional de Lanús

1 Mariana Mazover y Diego Quiroz escribieron, respectivamente, Piedras dentro de la Piedra y Los Tururú a partir de la novela picaresca Los Pichiciegos (1983) de Rodolfo Fogwill. Carlos Gamerro adaptó su propia ficción, Las Islas (1996), y la puso en escena con el mismo nombre bajo la dirección de Alejandro Tantanian. Mariano Saba ganó con Lógica del Naufragio el concurso realizado por el Instituto Nacional del Teatro. 
(una obra también basada en testimonios personales de excombatientes, ${ }^{2}$ pero representados por actores profesionales). Como buena parte de la dramaturgia $-\mathrm{y}$ de la producción audiovisual - sobre Malvinas, la pieza de Cardoso insiste en la patria como fundamento para la guerra, y persevera, con símbolos tan inequívocos como el himno o la bandera, en narrarla como gesta nacional. ${ }^{3}$ El dramaturgo habla de su obra explícitamente como un homenaje, como un "reconocimiento al sacrificio enorme que hicieron quienes combatieron" (Santoro cit. en Perera y Diz, 2016).

Campo Minado, entonces, no inaugura una dramaturgia sobre Malvinas basada en testimonios de excombatientes. Sin embargo, Arias inicia un tipo de teatro documental que al desplazar los ejes que generalmente organizan las narraciones sobre la guerra, crea nuevas imágenes y nuevas memorias sobre el conflicto bélico de 1982. Según Rosana Guber, la guerra solo mostró su eficacia, pero Malvinas funcionó como metáfora de la nación desde el siglo XIX. Pertenecientes al dominio territorial argentino solo de manera ideal, invadidas por el gigante colonial desde 1833, las Malvinas preservaron la "capacidad de encarnar la 'plena argentinidad' mucho más que cualquier otro símbolo que, dentro del continente, hubiera caído en el fuego cruzado de los enemigos" (Guber 164-165). Siempre en clave filial o familiar, profundiza Guber, Malvinas operó como metáfora de continuidad nacional, como símbolo construido de comunidad de pertenencia; símbolo que habla de las relaciones entre los sujetos, entre éstos y su Estado y con otros Estados.

Campo Minado, en cambio, subvierte dicha metáfora de Malvinas, desbarata su capacidad para funcionar como emblema de la nación. Estalla la cuestión de la soberanía sobre las Islas y sus disputas (aunque sin esconder los escombros de ese estallido). Igual que su dramaturga y directora, cuya producción despliega argumentos y espectáculos en múltiples lugares, ${ }^{4}$ Campo Minado combate las muy vapuleadas fronteras nacionales para esbozar una comunidad otra.

2 Además de correspondencia entre los soldados y sus familias durante la guerra, la obra también se basa en testimonios personales de excombatientes y de familiares de caídos en combate (Perera y Diz, "Memorias del pasado").

${ }^{3}$ Pienso, por ejemplo, en piezas teatrales como Mares de Piedra de Roxana Aramburú o Grietas de Lola Banfi, ganadoras del concurso Nuestro Teatro 2015, en homenaje a Teatro Abierto, presentadas en el Teatro del Picadero. La quintaesencia de este tipo de narración audiovisual es la reciente Soldado argentino solo conocido por Dios, del joven cineasta Fernández Engler, estrenada el 6 de abril del 2017.

${ }^{4}$ Arias trabaja simultáneamente en y a partir de varios países. Sus obras, filmes e instalaciones fueron presentadas en festivales internacionales en Alemania, Francia e Inglaterra y en espacios de arte de Buenos Aires, Los Ángeles, Mineápolis y Chicago. 
A lo largo del "experimento social" en el que transcurre la pieza, ${ }^{5}$ los seis excombatientes que pueblan el escenario - tres argentinos, dos ingleses, un gurkha- descentran la noción de comunidad nacional y crean un espacio de pertenencia atravesado por el disenso y la experiencia común, por el conflicto y la vivencia semejante, por el recuerdo traumático y la fuerza para rememorarlo, por el dolor y la potencia. Crean un espacio multilingüe y plurinacional desde donde se advierte la imposibilidad de una memoria única sobre Malvinas. Surgen así otras maneras de pensar y de narrar la guerra sin tonos épicos, interrumpiendo los anclajes nacionales y apartando, aunque sin silenciarlo, el reclamo por el dominio territorial y la disputa por el gobierno de las Islas.

\section{"Estoy ahí, con el enemigo, contándonos historias" (o sobre el teatro documental) ${ }^{6}$}

Entre el teatro documental y el biodrama, entre el testimonio y la ficción, Campo Minado retoma muchos de los procedimientos escénicos que Arias había utilizado en Mi vida después (una obra donde los actores recuerdan y actúan la vida de sus propios padres durante la última dictadura cívico-militar en Argentina) y en su texto gemelo sobre la dictadura chilena, El año en que nací. Recurriendo a la biografía personal, la historia colectiva o incluso a la "imaginación sociológica", según el libro homónimo de C. Wright Mills (1959), así como a documentos públicos y privados, Campo Minado reconstruye la experiencia de seis veteranos. Los 16 capítulos del texto dramático abarcan ininterrumpidamente el recorrido que va desde la reconstrucción de las entrevistas iniciales para la obra ("Audiciones") hasta la historia sociopolítica de las Islas narrada simultáneamente por un argentino y un inglés ("Malvinas"). La obra recupera experiencias de estos veteranos en la guerra: antes ("Convertirse en soldado", "Camino a la guerra"); durante ("El hundimiento del Belgrano", "Jets", "Mount Harriet", "Ultimo día de la guerra"), y después de su estancia en el territorio malvinense ("Vuelta a Casa", “Terapia”, "Por el Mundo"). La puesta en escena deja ver entonces el proceso creativo que la generó, al tiempo que reflexiona sobre el mismo. Revela, por ejemplo, escenas, canciones, formas de referirse al conflicto bélico que fueron excluidas del texto final. "Durante los ensayos..." es una frase que el público escucha en reiteradas ocasiones, evocando algunos de los dilemas y encrucijadas del proceso dramático dirigido por Arias.

${ }^{5}$ La propia Arias se refiere a sus obras como "experimiento social" (Arias y Kan, "Lola Arias"). Las páginas siguientes explican por qué.

${ }^{6}$ Todas las citas corresponden al registro audiovisual de la presentación de la obra en Inglaterra en 2016, cedido por la directora a la autora de el presente texto. 
Los actores de Campo Minado no son profesionales. Son los veteranos mismos quienes narran en escena, individual y grupalmente, sus propias vivencias de guerra. Colaborativamente, cada cuerpo relata también lo sucedido a otros. Dado que no hablan el idioma de sus otrora enemigos, la narración transcurre fundamentalmente en español y en inglés con traducciones subtituladas en el escenario. ${ }^{7}$ Campo Minado es un encuentro de cuerpos en 2016 afectados sensiblemente por sus enemigos de 1982; un colectivo sensible que, como dice en su presentación el antes soldado - hoy jardinero y campeón de triatlón- Marcelo Vallejo, "entiende muy pocas palabras pero en los gestos y las miradas [se] puede entender lo que [se] quieren decir".

Con un texto dramático escrito por Arias en colaboración con los seis excombatientes, cada actor reconstruye en escena tanto experiencias propias como ajenas, de sus pares allí presentes. Los veteranos devienen actores, pero no solo en el escenario: devienen también autores del texto dramático (co-escrito entre ellos y Arias) y por lo tanto de sus propias memorias. Dejan de ser así "las víctimas": decidieron, por ejemplo, no incluir en la obra escenas de torturas creadas y ensayadas durante el proceso de producción "porque nadie quería hacer el rol de víctima", explica el antes soldado - hoy abogado- Gabriel Sagastume. Dejaron de ser también "los héroes de Malvinas" homenajeados y formulados por otros. Estos veteranos devienen actores porque toman la palabra sobre la guerra y la vuelven dramática y bella para un público deseoso de escucharla. "Mi mujer me llama 'el monotema'. Me doy cuenta de que hablando de la guerra arruino todas las reuniones", confiesa al presentarse Gabriel Sagastume.

Campo Minado permitió a Sagastume y a sus compañeros crear memorias de la guerra transformando el tono del relato anterior. Les permitió hacerse dueños de las condiciones de producción (y de recepción) de su propio testimonio. No se trata ya de "una conversación que arruina reuniones", ni tampoco de una gesta, una epopeya o una causa nacional. Tampoco se trata de una guerra condenada al olvido por su asociación con la última dictadura argentina. Campo Minado es un "experimento social" donde el escenario se vuelve un espacio de encuentro de cuerpos sensibles que toman la palabra sobre la guerra, junto con sus otrora enemigos, para producir relatos multisituados y necesariamente conflictivos,

7 En varias escenas, el antes gurkha, hoy empleado de seguridad, Sukrin Rai, trae el universo cultural y artístico de Nepal en su originario nepalí. Estas intervenciones poéticas no se traducen. "Siempre se pierde algo en la traducción. Es mejor dejarlo en un lenguaje poético abierto, para no perder riqueza o valor cultural", dijo Arias en una entrevista realizada por Gonzalo Aguilar que siguió a la representación de la obra el 2 de diciembre de 2016 en el Centro de Artes Experimentales de la Universidad Nacional de San Martín (UNSAM) en Buenos Aires. 
generando un testimonio dirigido a un público grande. ${ }^{8}$ El acontecimiento implica "una alteridad en diálogo" que, como escribe Jelin, es una de las condiciones que hacen posible el testimonio.

\section{Multimedia: relatos multiescalares y multisituados (o sobre el disenso y la memoria)}

Siguiendo con los procedimientos escénicos de Mi vida después y El año en que nací (y en la línea del teatro documental), ${ }^{9}$ Campo Minado es, entre otras cosas, un montaje de documentos públicos y privados. Pero a diferencia del teatro documental "clásico" (sistematizado por Peter Weiss en 1968), en la obra de Arias los documentos públicos alojan también lo íntimo.

Además de su valor histórico, los documentos públicos se utilizan como recursos para narrar lo singular de la biografía y la intimidad de la vivencia, como por ejemplo las fotos y videos de archivos de las Fuerzas Armadas argentinas y británicas que retratan individual y grupalmente a los soldados (imágenes del crucero General Belgrano y del transatlántico Canberra), las triunfalistas tapas de algunas revistas argentinas (como la bien conocida "Seguimos Ganando" de Gente), o incluso algunos videos del fervoroso apoyo popular a la guerra el 2 de abril en Plaza de Mayo, entre otras propagandas oficiales.

Todos estos archivos aparecen en la obra como certificados históricos que brindan información y elaboran el contexto sociopolítico, además de representar espacios donde se alojan pensamientos difíciles de compartir y sentimientos incómodos que marcaron la vida en la guerra. Con estas imágenes, los veteranos reconstruyen acontecimientos importantes del conflicto bélico: la toma de la Casa de Gobierno en Puerto Stanley el 2 de abril, o el hundimiento del General Belgrano o la maratónica campaña televisiva argentina para recaudar fondos que nunca llegaron a destino. Pero también comparten a partir de ellas, por ejemplo, los motivos (nada heroicos) que los llevaron a unirse a las Fuerzas Armadas: "Para escaparme de casa a los dieciséis", cuenta el antes marino inglés - hoy maestro de niño/as con problemas de aprendizaje-, Lou Armour; o la fantasía de "viajar a playas caribeñas con palmeras", explica el hoy sicólogo David Jackson; o simplemente porque "yo sí quería ser soldado" confiesa el argentino Marcelo Vallejo.

Las fotografías acomodan recuerdos - a veces narrados, a veces actuados - de terror

${ }^{8}$ Fue notable la cantidad de público que no pudo entrar a las funciones de noviembre y diciembre de 2016, en el Centro de Artes Experimentales de la UnSAm en Buenos Aires.

9 Ver Sabugal Paz, "Teatro documental". 
y de alivio, de desesperación y de consuelo. Desde las náuseas a bordo hasta la fiesta de los concursos de canto, rematando con los performances travestidos al compás de la Banda de la Marina Real (recreados en la puesta en escena con el striptease travestido de David Jackson), los veteranos rememoran y reconstruyen un repertorio sensible, complejo y variado.

Algunos de los documentos proyectados son inequívocamente privados y enmarcan intimidades. La carta que Gabriel Sagastume escribió a Florencia (quien en aquel momento era su novia y ahora su esposa), le permite hablar del tedio de la espera en la guerra mientras "nada pasa realmente". La proyección del diario íntimo que Lou Armour escribió durante los ensayos en Buenos Aires, confirma al público que Campo Minado reabrió en los veteranos-actores memorias traumáticas difíciles de elaborar, como resultaba previsible. "Algunas preguntas me trajeron recuerdos del pasado lejano; cosas de las que nunca había hablado. No podía dormir, tenía flashbacks, mi mente se apagaba”, confiesa Lou Armour en escena y comparte con el público su decisión de consultar un sicólogo. Algunos documentos son auditivos: como los discursos que inauguraron y concluyeron la guerra en Plaza de Mayo y en el Parlamento inglés y que acompañan, respectivamente, los performances de Sagastume y de Armour con las máscaras de sus líderes, Leopoldo Galtieri y Margaret Thatcher.

La puesta en escena interviene la forma - o la escala - de los documentos utilizados: aparecen siempre proyectados sobre el telón de fondo en tamaño mural, y muchas veces se ilumina en el escenario al dispositivo y al actor que los proyecta y agranda. Así se evocan las múltiples escalas que el texto dramático explora. Desde una reconstrucción crítica del contexto sociopolítico y de los acontecimientos fundamentales, hasta la impugnación al (sin)sentido de la guerra; desde los traumas individuales hasta los vínculos malheridos; desde el entrenamiento físico hasta la vida cotidiana del soldado; desde el hambre y el frío hasta el canto y el striptease travestido para evadirse de la guerra..., la obra de Arias visibiliza matices que interrumpen las claves que suelen organizar las narraciones sobre Malvinas.

Lo matizado y lo multiescalar se complementa, además, con lo multisituado: los relatos se construyen simultáneamente desde situaciones diferentes pero igualmente valoradas; las memorias se recuperan, sincrónicamente, desde posiciones contrapuestas. Surge así una narración atravesada por el disenso y el conflicto transformado: puntos de vista otrora enemigos se legitiman en una misma escena y se integran en una familia de relatos paralelos. Me detengo en dos ejemplos: mientras el argentino Rubén Otero recrea el trauma de cómo sobrevivió al bombardeo del crucero General Belgrano, el inglés Lou Armour rememora el alivio que sintió al saber del hundimiento. El argentino recuerda las 41 horas a bordo de una balsa, intentando no dormirse junto a otros 21 tripulantes y la mitad de su 
cuerpo congelado cuando llegó el rescate del destructor Bouchard. Concluye la escena con un poderoso y catártico solo de batería, ${ }^{10}$ al grito de "i323 muertos!" (la mitad de todos los caídos en la guerra) y “iMalvinas!". El inglés interrumpe la escena para legitimar en tono firme y sereno su sentimiento de alivio: si bien el Belgrano estaba fuera de la zona de exclusión establecida por Inglaterra y se estaba yendo al momento del bombardeo, era una amenaza real y podría haber dado la vuelta para atacarlos.

Otro ejemplo: la inclusión de Sukrin Rai entre los actores habilita al texto dramático de Arias a degradar y celebrar, simultáneamente, la figura de los ghurkas. Para los rumores argentinos recuperados y narrados por Marcelo Vallejo, los ghurkas son "tristemente célebres asesinos", quienes "despedazaron cuerpos" luego de "matar a 300 argentinos" en Goose Green, y hasta "se comieron las orejas" que amputaron a sus enemigos.

A esta escena le sigue otra que recrea un ficcionalizado reality show, dirigido por un ficcionalizado conductor de Tv, actuado por Lou Armour. Marcelo Vallejo y Sukrin Rai se encuentran como invitados en un set televisivo, no sólo para confrontar retratos de los gurkhas sino también para cotejar sus acciones violentas del pasado con los sentimientos amables y transformados del presente. El personaje del conductor introduce a Sukrin como parte de los "buenos servidores de la corona británica por más de 200 años", quienes entregaron "50,000 vidas por Inglaterra durante la Primera y la Segunda Guerra Mundial". Se trata, dice, de "guerreros nepaleses famosos por su habilidad con el cuchillo, el famoso kukri", quienes tienen una "aterradora reputación que los acompañó hasta las Islas Falkland". Invita luego a Sukrin a relatar como "salvó" a un oficial argentino -a quien años más tarde encontró en Buenos Aires durante los ensayos de la obra- porque "capturar es mejor que matar". Si la guerra hubiera durado un solo día más, dice el conductor del reality, estos veteranos se hubieran encontrado e intentado matarse en el campo de batalla de Mount William. Hoy, Marcelo Vallejo ya no quiere "cagar a trompadas a un gurkha", sino más bien "tomarse una cerveza con Sukrin". El antes guerrero cierra la escena solo en un escenario despojado y dulcemente iluminado dedicándole una suave canción nepalí a Vallejo.

Todo en la obra de Arias aparece con esta perspectiva multisituada; hasta la soberanía sobre las Islas, que "no se discute". Pero la cuestión tampoco se oculta "bajo un paraguas", como la expresión que reflejaba la política oficial sobre Malvinas durante el gobierno menemista (1989-1999). Campo Minado no esconde ni el malestar ni la pérdida que la soberanía disputada causa todavía hoy: la obra da lugar al fuego cruzado de acusaciones mutuas y aloja reclamos opuestos y legitimaciones confrontadas, tal como se describe en el apartado siguiente.

${ }^{10}$ El catártico solo de batería es un recurso que Arias utilizó en Mi Vida Después con Carla. Agradezco a Natalia Fortuny esta observación. 


\section{"Nosotros decimos que las Malvinas son argentinas. Ellos que los isleños son ingleses" (o la soberanía como pregunta)}

"No quiero terminar la obra con un mensaje o con una afirmación (...) prefiero terminar con preguntas", dijo Arias en una entrevista pública realizada por Gonzalo Aguilar, luego de la función del 2 de diciembre del 2016 en el Centro de Artes Experimentales de la Universidad Nacional de San Martín. En realidad, toda la obra está atravesada por interrogantes, desde las demográficas dirigidas a los actores que recrean las audiciones en la escena inaugural (nombre, edad, rango y ocupación actual, por ejemplo), hasta las ético-políticas que interrogan el (sin)sentido de la guerra en la canción final compuesta y cantada en vivo por los propios veteranos. Campo Minado comienza y termina con preguntas explícitas que interpelan a los cuerpos dentro y fuera del escenario. La obra pregunta, asimismo, por la soberanía sobre las Islas. Más que reivindicarla, la cuestiona; más que disputarla, la sustrae. Y así, entre el cuestionamiento y la sustracción, mina lo que más contundentemente legitima a la guerra: la importancia de la soberanía nacional sobre las Islas para su propia trama de memorias sobre Malvinas.

Entre la directora y los actores decidieron poner la cuestión entre paréntesis: "Durante los ensayos entre los veteranos, no discutimos el problema de la soberanía sobre las Islas. Nosotros decimos que las Malvinas son argentinas, ellos, que los isleños son ingleses", dice Rubén Otero en el escenario. "La soberanía es algo de lo no dicho, o de lo que decidimos dejar afuera, porque [los excombatientes] no se iban a encontrar ahí," dijo Arias en la misma entrevista de 2016. La soberanía como pregunta, antes que como reclamo, no fue sin embargo una posición fácil o cómoda, exenta de resistencias. Desde el gobierno argentino hasta los propios actores y gente de Buenos Aires, impugnaban el gesto de fugarse de la disputa por la soberanía.

Cuando el proyecto contaba con apoyo financiero de festivales y otras instituciones británicas y europeas, Arias buscó una participación simétrica en la Argentina, pero no halló ningún apoyo en este país sino hasta que dio con el interés de la Universidad Nacional de General San Martín. Ministerios de gobierno y teatros oficiales rechazaron la idea de una obra de teatro sobre Malvinas que narraba la guerra "desde los dos lados" y evitaba el reclamo por la soberanía.

En algunas cartas de espectadores de teatro dirigidas a los veteranos, se leía incluso: "yo no me voy a sentar en el público a aplaudir a esos ingleses que mataron a nuestros hermanos". Y en la primera etapa del proceso dramatúrgico, de hecho, durante las entrevistas y audiciones iniciales, los propios actores no podían entender que participar en la obra, encontrarse en el escenario y "comprender el dolor, el sufrimiento y las experiencias del otro lado", no implicaba resignar el reclamo de soberanía sobre las islas. 
En una entrevista personal realizada el 12 de septiembre de 2017 a la autora, sin embargo, ésta narra cómo las resistencias se fueron disipando avanzados los ensayos. Actores, público y diversas asociaciones de excombatientes celebraron la decisión estético-política de no centrarse en la disputa por el dominio territorial sobre las Islas para esta creación escénica.

Pero para convivir en el conflicto hace falta expresarlo y para habitar el disenso es necesario visibilizarlo. Campo Minado no reivindica el dominio territorial sobre las Islas para la Argentina -y tampoco para Inglaterra-, no reclama la gestión del territorio isleño del Atlántico Sur para ninguna de las partes. Pero tampoco propone "un relato protopacifista que reúne a los opuestos y les imparte una fraternidad", tal como Martín Kohan (271) escribe a partir de la literatura sobre Malvinas. Campo Minado no le escapa a la hostilidad, el padecimiento o la pérdida ocurrida en nombre de la lucha por la soberanía nacional. No silencia ni esconde el trauma de una guerra legitimada en fronteras nacionales.

Paradójicamente, el capítulo llamado "Malvinas/Falklands" se aleja de todo emblema de nación. Dos veteranos argentinos abren la escena cantando el himno argentino a las Islas sin parodiarlo pero sin ninguna solemnidad. Inmediatamente se narran dos versiones, una "argentina", otra "inglesa", de la historia sociopolítica del territorio malvinense y, con excepción de Sukrin, cinco veteranos vociferan acusaciones recíprocas exponiendo desde crímenes de guerra (en que los ingleses atacaron a civiles violando la Cuarta Convención de Ginebra) hasta las torturas de combatientes argentinos por parte de sus propios oficiales. No simulan fraternidad ni universalismo alguno. Desnudan, en cambio, el absurdo y la desolación, el sinsentido y la congoja de toda guerra. Se gritan:

Aloja acusaciones mutuas soberan edes perdian la mor de Dios!"y mataron a tres mujeres civiles"oldados argentinos en itieron ir ¡A nosotros nos dijeron que ustedes no sabían por qué peleaban!

¡A nosotros nos dijeron que su gobierno mataba a su propia gente!

¡Ustedes nos cagaban a bombazos todos los fines de semana porque les pagaban más! ¡Cayó un helicóptero británico y ustedes dispararon a sus tripulantes cuando nadaban a la orilla para salvarse!

¡Ustedes hundieron al Belgrano fuera de la zona de exclusión!

¡Ustedes pusieron piezas de artillería en los jardines de civiles en Puerto Stanley!

¡Ustedes bombardearon por error a una casa en Puerto Argentino y mataron a tres mujeres civiles!

¡Ustedes izaron la bandera blanca en Goose Green, esperaron a que pasaran los soldados británicos y les dispararon por la espalda!

¡Ustedes remataban a los heridos en Monte Longdon!

¡Ustedes torturaban a sus propias tropas, por el amor de Dios! 
La obra se sustrae "del problema de la soberanía nacional" pero no oculta sus efectos sobre los cuerpos en la guerra, abriendo así el espacio para otras preguntas que revisan y recrean memorias sobre Malvinas. La libertad para distanciarse del pilar que sostiene simbólicamente a la guerra, abrió la posibilidad de socavarla, impugnando su sinsentido mediante preguntas. “¿Por qué digo 'yo' en lugar de 'nosotros'?”, pregunta David Jackson replanteándose quién habla (y quién tiene derecho a hacerlo) a través de sus propios relatos sobre el conflicto bélico de 1982. “¿Tengo el derecho a hablar en nombre de aquellos que fueron a la guerra y no volvieron? ¿Dónde están los muertos británicos en esta obra?", continúa. La ausencia deliberada de reclamos nacionales deja espacios de libertad para agitar interrogantes que resignifican la remembranza de la contienda. Fundamentalmente, se abren así espacios para rechazar la guerra toda y toda la tragedia de la guerra.

Es desde ese espacio de libertad que irrumpe la escena donde - los antes soldadosdevienen una poderosa banda de rock. Completada con una dulce poesía nepalí no traducida desde la boca de Sukrin, esta escena cierra la obra. Arias pidió a los actores que compusieran una canción "solo con preguntas" (Entrevista, 2017) para ser cantada por ellos mismos en vivo. Lou Armour, "cantante principal" de la banda de rock resultante (Jackson y Sagastume en guitarras eléctricas, Vallejo en el bajo y Otero en la batería), pregunta sobre los límites de lo que puede un cuerpo en la guerra. Nos obliga a meditar sobre la distribución horrorosamente arbitraria de vida y muerte, de lo que se protege y lo que se abandona en la guerra (y no solamente en ella):

¿Mandarías a tus hijos o tus hijas a la guerra? ¿Por qué pelearías? ¿La reina? ¿La patria? ¿Petróleo? ¿Alguna vez mataste a alguien? ¿Viste morir a alguien? ¿Alguna vez te sentiste ignorado por el gobierno que te mandó a la guerra? ¿Alguno de tus amigos se suicidó? ¿Alguna vez viste a alguien prendido de fuego? ¿Alguna vez viste a alguien ahogarse en el mar helado? ¿Alguna vez fuiste a la guerra?

Entre otras, estas preguntas interpelan a actores y a espectadores, a los cuerpos dentro y fuera del escenario. “¿Lo hiciste? ¿Lo harías?”, intercala la canción a modo de estribillo. No son enunciados de cualquier cuerpo, no provienen de un actor representando un papel, ¡son alaridos de cuerpos que vivieron y volvieron del campo de batalla! Son preguntas dirigidas a ellos mismos y dirigidas también a nosotros - espectadores- que en general poco sabemos de la guerra. Son preguntas que nos acercan a esa repartija absurda de formas de muerte que hace la guerra. Nos fuerzan a pensar sobre los límites de vida y muerte, que son el meollo mismo de la experiencia en la guerra. Nos obligan a pensar en nuestros límites, si estuviéramos - o no- en situación de guerra. 
La canción impugna la guerra sin moralizar ni distribuir rápida o fácilmente el bien y el mal; el honor y la humillación; los héroes, las víctimas y los villanos; lo propio y lo ajeno. Pues suspendido "el problema de la soberanía nacional" - el constructo que la legitima - nada impide rechazar la guerra toda. "Descubrí que nadie está preparado para la guerra", dijo Arias refiriéndose a los soldados ingleses entrenados profesionalmente y dispuestos a combatir en condiciones mucho más favorables que sus enemigos argentinos. Es que sabemos que más allá de la victoria o la derrota, no hay monopolio nacional para el trauma de la guerra.

\section{"Ese campo minado lo había puesto el Ejército Argentino..." (o a modo de conclusión)}

El nombre de la obra refiere, entre otras cosas, a un campo de batalla literalmente minado. Con la ayuda de Marcelo Vallejo manipulando pequeños objetos en una maqueta que se proyecta sobre el fondo del escenario, Gabriel Sagastume reconstruye la explosión de una mina personal en el Monte Wireless Ridge, que mató a cuatro de sus compañeros mientras volvían de robar comida. Un suboficial ordenó más tarde a Sagastume, entre otros, recoger los restos de los muertos y los heridos con sus propias frazadas. Sagastume reconoció la pierna de su compañero Vargas "porque usaba unas medias de fútbol con rayas de colores..." "Después nos enteramos", concluye él mismo al cierre de esa secuencia, "que ese campo minado lo había puesto el ejército argentino al principio de la guerra y nadie nos había avisado". Es esta escena la que nombra la obra, aludiendo al abandono de los cuerpos a la muerte - los "cuerpos propios", no los "cuerpos enemigos"- por parte de su propio Estado nacional.

Sin victimizarlo todo ni a todos, sin identificarse con la comunidad nacional pero sin privarse de la denuncia tampoco, la escena insiste en nombrar un Estado argentino que incumplió el contrato social que lo une al soldado-ciudadano. Campo Minado acusa a un ejército donde los oficiales son enemigos y torturadores de sus propios soldados, quienes están mal alimentados y abrigados, muy mal provistos de armamentos, desinformados y pésimamente entrenados para combatir.

Pero ese no es el único campo minado en la obra de Arias, como hemos visto. La puesta en escena mina también los ejes que suelen organizar las narraciones de Malvinas: no recupera héroes ni anti-héroes, no homenajea víctimas. Invita a excombatientes a convertirse en emprendedores de memoria, ${ }^{11}$ quienes, reconociendo el poder y los efectos que la nación

11 Jelin habla de "emprendedores de memoria" para enfatizar su capacidad de innovación y creatividad en la construcción de memorias y diferenciarlos de los "militantes de la memoria", tal vez más próximos a repeticiones ritualizadas $(48)$. 
inscribe en los cuerpos, no se identifican exclusiva o principalmente con ella. Pero tampoco se adscriben a una universalidad que adjudica hermandades banales y superfluas.

Como parte de lo que solo la ficción literaria puede lograr, diría Martín Kohan (El país), Campo Minado estalla los pilares que sostienen la guerra. Para este crítico, es sólo el terreno inaugurado por Fogwill con Los Pichiciegos el que es capaz de "desarticular lo nacional" y socavar esas nociones que - como las de "patria", "honor", "sacrificio" y "nación"- legitiman o al menos apuntalan la guerra; mientras que para el género testimonial eso resulta difícil. El testimonio no puede vaciar la tragedia de lo ocurrido en Malvinas, no puede dejar de denunciar las distintas atrocidades cometidas - desde la manipulación perpetrada por parte de la dictadura cívico-militar, hasta los crímenes de lesa humanidad cometidos-. De esta manera, agrega Kohan:

En el registro testimonial, por lo pronto, hay un límite muy difícil de franquear [...] se percibe un cierto consenso, y hasta podría decirse una cierta unanimidad, acerca de la legitimidad y la relevancia de la empresa de la recuperación de las islas, la vigencia prácticamente intocada de los credos de la argentinidad, con sus correspondientes vehemencias y sus correspondientes emociones, y la disposición manifiesta de volver a pelear por las islas en una guerra, siempre que se cuente con eso que en el 82 faltó: una preparación adecuada, una dirección inteligente, un pertrechamiento satisfactorio $(269-270)$.

En tanto teatro documental basado en testimonios, Campo Minado interrumpe ese consenso, descalabra "los credos de la argentinidad". No reclama soberanía nacional para ninguna de las partes y menos aún rescata algún valor en la recuperación argentina de las islas o en la disposición de volver a pelear en condiciones adecuadas. Pero tampoco sugiere una esencia humanista o una fraternidad capaz de transcenderlo todo. Se reserva el derecho a la denuncia sobre el poder y los efectos que las fronteras nacionales inscriben en los cuerpos. La obra reconoce las violencias y los padecimientos, las muertes y las pérdidas ocurridas en nombre de las luchas por la soberanía nacional. No evade el trauma de una guerra legitimada en los límites de la nación. Le da lugar a las acusaciones recíprocas, los reclamos opuestos y las legitimaciones rivales. Y desde ese campo minado, abre el espacio para preguntas-otras que impugnan la guerra toda, y todo el absurdo de la guerra. Desde ese campo minado, imagina una comunidad otra, sin esencias, lengua, religión ni nación en común. Surge un convivio multilingüe y plurinacional capaz de generar relatos y memorias sobre Malvinas atravesadas por la experiencia común y la vivencia semejante, pero también cargadas del disenso y del conflicto; memorias que recuperan el trauma de la guerra pero también la potencia para elaborarlo. 


\section{Bibliografía}

Arias, Lola. Entrevista personal con Verónica Perera. 12 de septiembre de 2017. Transcripción de archivo de audio.

Arias, Lola. Campo Minado. Festival de Brighton en Inglaterra de mayo de 2016. Arias, Lola. Mi vida después y otros textos. Buenos Aires: Penguin Random House, 2016. Arias, Lola. Entrevista pública con Gonzalo Aguilar. 2 de diciembre de 2016. (La entrevista se realizó a continuación de la función del 2 de diciembre en el Centro de Artes Experimentales de la UNSAM en Buenos Aires). Transcripción de archivo de audio. Arias, Lola, y Eliana Kan. "Lola Arias by Elianna Kan”. BOMB, no. 128, 2014, pp. 58-64. Fogwill, Rodolfo. Los Pichiciegos. Buenos Aires: Interzona, 2012.

Gamerro, Carlos. Las Islas. Buenos Aires: Edhasa, 2012.

Guber, Rosana. ¿Por qué Malvinas? Buenos Aires: Fondo de Cultura Económica, 2001. Halbwachs, Maurice. La memoria colectiva. Buenos Aires: Miño y Dávila, 2011. Jelin, Elizabeth. Los trabajos de la memoria. Madrid: Siglo xxi Editores, 2002.

Kohan, Martín. El país de la guerra. Buenos Aires: Eterna Cadencia, 2014.

Perera, Verónica y Diz, María Luisa. "Memorias del pasado reciente: la guerra de Malvinas en el teatro independiente". Jornadas de Estudios sobre el Teatro Independiente, Centro Cultural de la Cooperación Floreal Gorini. 22 y 23 de septiembre de 2016, Buenos Aires. Ponencia.

Sabugal Paz, Paulina. “Teatro Documental: entre la realidad y la ficción”. Investigación Teatral, vols. 6-7, números 10-11, 2016, pp. 111-129.

Weiss, Peter. Escritos políticos. Barcelona: Editorial Lumen, 1976. 


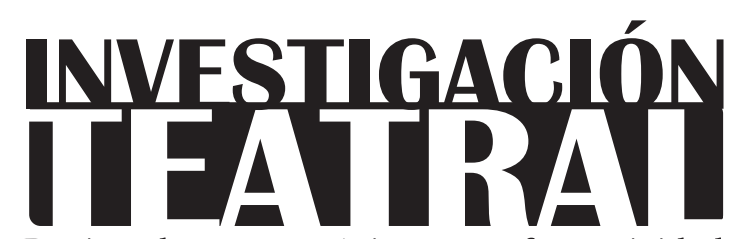

Revista de artes escénicas y performatividad

Vol. 9, Núm. 13

abril-septiembre 2018

Segunda época

ISSN impreso: 1665-8728

ISSN electrónico: 2594-0953

Universidad Veracruzana

\section{Reseña del libro:}

\section{El teatro depurado $y \sin$ concesiones de Ludwik Margules}

Rodolfo Obregón*

\footnotetext{
* Centro Nacional de Investigación, Documentación e Información Teatral "Rodolfo Usigli"-INBA, México. e-mail: pasofranco@att.net.mx.
} 


\section{El teatro depurado y sin concesiones de Ludwik Margules}

María Teresa Paulín. El teatro depurado y sin concesiones de Ludwik Margules. México: Paso de Gato, Serie Teoría y Técnica, 2017, 272 pp.

$\mathrm{H}$ ay pocos artistas en la escena mexicana cuyo trabajo haya sido documentado tan detalladamente y despierte tanto interés como el de Ludwik Margules. Una década después de su desaparición, contamos con uno de los archivos teatrales más ricos bajo resguardo del CITRU, conservado en óptimas condiciones, además de que existe un libro de memorias y otro de testimonios de amigos y colaboradores; la bitácora publicada de su puesta en escena de Cuarteto, capítulos de algunos libros, un DVD-ROM con una cantidad amplísima de documentos (entre ellos, múltiples artículos y ensayos de y sobre Margules), así como varios programas documentales en torno a su figura y obra.

Como autor o promotor de una parte significativa de estos materiales (y aquí explicito el lugar desde el que escribo), espero con ansias el o los trabajos analíticos que permitan ahondar en las aportaciones de Margules y ayuden a sedimentar su herencia. Sobra decir que el problema de la transmisión es, sin duda, uno de los grandes lastres no exclusivos de nuestra escena. La publicación de la tesis doctoral presentada en La Sorbonne Nouvelle por Teresa Paulín, bajo el título de El teatro depurado y sin concesiones de Ludwik Margules, parecía llamada a llenar esas expectativas. Sin embargo, antes de entrar en la estructura y aportaciones del libro, es necesario señalar un cúmulo de errores que denotan la prisa en su realización, dificultan la lectura y distraen con excesiva frecuencia la atención del lector informado.

Ni Alejandro Luna es el autor del vestuario de El círculo de tiza caucasiano, El tío Vania o la opera Fausto - como puede consultarse en el DVD-ROM que la autora cita repetidamente y de donde extrajo algunas imágenes-; ni Ante varias esfinges es una obra de Juan Tovar, sino de Jorge Ibargüengoitia (tal y como aparece en los listados del propio libro); por 
mencionar únicamente dos errores que se repiten a lo largo de sus páginas. Estos son detalles que en parte podría haber corregido un editor menos complaciente, quien tampoco debió permitir que se copiara la "Tabla cronológica" del libro Ludwik Margules, Memorias sin el crédito correspondiente y con las erratas incluidas (de forma tan evidente que las fechas de la tabla no coinciden con las de la "Lista de obras" ni con otras que aparecen en el cuerpo del texto).

Pero, lo que resulta imperdonable es haber dejado pasar las cinco páginas introductorias sobre historia del teatro local, con las que la autora pudo sortear la ignorancia de algunos académicos franceses sobre un tema tan particular, pero que en realidad constituyen un collage arbitrario de lugares comunes, faltas de actualización y lagunas tan importantes, como borrar de un plumazo a Salvador Novo y los otros Contemporáneos que ejercieron la dirección de escena; todo para acomodar la historia a los maestros de Margules.

En cuanto al planteamiento estructural de la investigación, que David Olguín festeja en su prólogo, éste implica una breve semblanza biográfica, el rescate de las herramientas de trabajo de Ludwik Margules (ya enfatizadas en el $D V D-R O M$ mencionado) y una revisión de obras altamente significativas en su trayectoria, para adentrarse finalmente en la metodología de trabajo del director polaco-mexicano y sus relaciones con el espectador. Si los dos primeros rubros permiten, e incluso exigen, un enfoque fundamentalmente descriptivo - que es el que se hace presente en todo el libro-, se echa de menos un planteamiento crítico para el análisis de las obras seleccionadas. En la abundante documentación utilizada para sustentar los capítulos correspondientes, es siempre la palabra del propio Margules la que prevalece, mientras se ignora la mirada de los testigos especializados, que serviría para verificar la coincidencia entre las intenciones manifiestas por el director y los resultados tangibles sobre el escenario (en obras que, por su edad, la autora no pudo conocer de primera mano).

El texto se acerca así a una peligrosa literalidad (cuantimás evidente frente a una personalidad y un lenguaje tan proclives a la exageración y a convertir todo en literatura, como son los de Margules), o definitivamente a la inmediatez, reduciendo la amplísima trayectoria del director a la etapa última de su vida y obra, en la que Paulín convivió con él como estudiante del Foro Teatro Contemporáneo. Una inmediatez también manifiesta en el hecho de que el veinte por ciento de las entrevistas realizadas como parte del proceso de investigación hayan sido hechas a compañeros estudiantes que poco tienen que aportar en la materia, o en afirmaciones insostenibles como que Franz Castorf sea una influencia significativa en la concepción de la puesta en escena de Margules (simplemente porque el director alemán pasó por México en aquellos días).

Queda entonces pospuesta, para futuros trabajos, la posibilidad de escudriñar la temática de las obras llevadas a escena por Margules y anudarla con su posición y experiencia vitales, para evitar la repetición de frases y tópicos propios del director como 
"la exploración de la condición humana", "el hombre sujeto a los mecanismos del poder", etcétera, sin adentrarse justamente $-\mathrm{y}$ como se esperaría de un trabajo académico- en la forma específica en que estos encarnaron en la escena marguliana. Entonces podrán establecerse la evolución y los vaivenes de la estética de su puesta en escena, incluida la última etapa de su teatro, donde aparece reiteradamente la palabra "depuración" (una palabra de la que se abusa hasta en la cuarta de forros del libro) sin que ésta quede reducida a la "economía de medios" y a la "centralidad del actor" (una vez más, frases usadas una y otra vez, tanto por Margules como por todos aquellos que hemos intentado acercarnos a su trabajo).

En ese mismo sentido, la selección de obras reseñadas por Teresa Paulín puede funcionar como una guía, a la que habría que añadir El círculo de tiza caucasiano que, según ha expresado Alejandro Luna, fue más definitoria de la estética cultivada por la pareja creativa que el mismo Fausto de Marlowe; y, desde luego, Jacques y su amo, un verdadero punto de inflexión en el teatro de Margules y sin la cual se abre un abismo estilístico entre De la vida de las marionetas y Cuarteto, escenificaciones separadas por casi quince años.

La última parte del libro, donde se da cuenta (una vez más) de manera descriptiva la metodología de dirección utilizada, es sin duda la que más aporta al conocimiento de esta figura de nuestro teatro, pues se sustenta fundamentalmente en las bitácoras de trabajo que elaboraban sus asistentes o colaboradores. Ahí es posible reconocer la forma en que el director guiaba la inmersión paulatina de sus elencos en los universos de las obras elegidas, y la manera en que regularmente pasaba de ahí al montaje y a la confrontación con el espectador -las excepciones, como los procesos de Jacques y su amo o Camino rojo a Sabaiba, tampoco dejan de ser interesantes-. Para tener una idea más completa de los procedimientos utilizados por Margules, en diversos momentos de su trayectoria, habría que sumar a esta descripción el método de análisis que él adaptó de Curtis Canfield, mismo que enseñaba a sus alumnos de dirección y dio estructura a varios de sus cuadernos; así como los procesos de "sobreposición de emociones" con los que se consiguió la complejidad actoral en De la vida de las marionetas, o las sobreposiciones temáticas practicadas en Cuarteto y descritas en la única bitácora publicada hasta ahora.

Estas ausencias en el libro de Paulín se explican porque en los capítulos finales prevalece también el Margules que la autora llegó a conocer y una visión a partir de las afinidades que estableció en ese momento, la época de Los justos. Y sin embargo, esas últimas páginas tampoco están exentas de cierta ingenuidad, como incluir en la descripción frases y expresiones de ese "folclor personal" que Margules detestaba, o sostener que fue él el primer director mexicano que llevó a cabo un trabajo de mesa extenso y riguroso, o el primero en buscar una actoralidad auténtica, libre de histrionismos o engaños; o también "el primer 
director que comenzó a independizar el lenguaje de la puesta en escena", con lo que ignora a tantos otros creadores que le antecedieron o acompañaron en ambos sentidos.

Y aquí el problema medular del libro que se extiende desde el título hasta las conclusiones: la mitificación - otra práctica que Margules combatió ferozmente aunque, en una más de sus fascinantes contradicciones, contribuyera tanto a ella- ¿ ¿Cuáles son esas "concesiones" que el teatro de este director no hizo? ¿En qué consiste su tan mentada transgresión y cómo se realiza? ¿Es posible hablar en el teatro mexicano de hoy como si estuviéramos aún en la época de Usigli, de "el primero" y "el último"? ¿Tienen cabida en un trabajo académico expresiones como "su obra maestra", "la cima de su arte" o "su etapa de gloria"? ¿No hay diferencia alguna entre el contexto en que vivió y trabajó este creador y el actual?

Como aprendimos de Ludwik Margules, la mitificación sirve principalmente para legitimar y solidificar una cadena de poder y termina siempre, contrario a sus intenciones, por poner a "sana distancia" al creador o a su obra. Es la crítica lo que posibilita la transmisión del conocimiento y lo que consolida una tradición; paradójicamente, es sólo a través de esa distancia inicial que es posible llevar a cabo la asimilación de una herencia. 


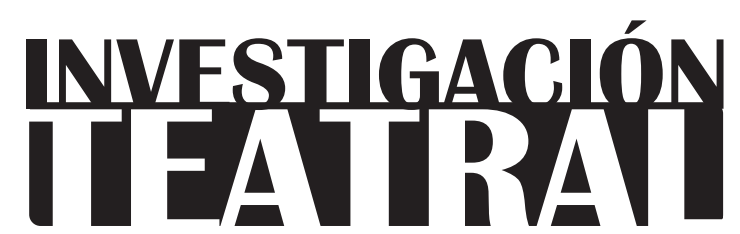

Revista de artes escénicas y performatividad

Vol. 9, Núm. 13

abril-septiembre 2018

Segunda época

ISSN impreso: 1665-8728

ISSN electrónico: 2594-0953

Universidad Veracruzana

Reseña de la

puesta en escena:

\section{La extinta variedad del mundo de Alberto Villarreal}

Saúl Rivas Meléndez*

\footnotetext{
* Maestría en Artes Escénicas, Universidad Veracruzana, México.

e-mail:dimo14@hotmail.com
} 


\section{La extinta variedad del mundo de Alberto Villarreal} a extinta variedad del mundo, obra que Alberto Villarreal escribió y dirigió para la Compañía Titular de Teatro de la Universidad Veracruzana, fue uno de los espectáculos más notables estrenados durante 2017 en la ciudad de Xalapa, Veracruz. Se trató de un montaje situado en las fronteras del teatro convencional, por su trabajo con una estética performativa que se vale de acciones físicas, objetos, música en vivo, máscaras y disfraces grotescos para generar un universo simbólico de lectura amplia para el espectador. El cuerpo del los actores se llevó al límite de la expresividad gestual y coreográfica sin recurrir al uso de la palabra hablada.

La extinta variedad del mundo realizó una aguda parodia a las figuras de autoridad, escenificando a 'gobernantes' que ya ni caminar quieren, pero ejercen violencia sobre los ciudadanos. Se realizaba así mismo una crítica a la manera en que las multitudes siguen ciegamente a los líderes o políticos. La puesta en escena planteó preguntas como: ¿qué se gana y que se pierde cuando homogenizamos el mundo?, ¿puede más el temor a lo diferente que la curiosidad por conocer lo desconocido?, o ¿hasta qué punto somos cómplices del fascismo o partícipes de la violencia de Estado? La obra se presentó del 10 al 24 de noviembre de 2017 en la sala Dagoberto Guillaumin del Teatro del Estado Gral. Ignacio de la Llave, con capacidad para 260 personas, sobre un escenario 'a la italiana'. A la función que aquí se reseña, la del día 11 de noviembre, acudimos entre 100 y 120 personas, en su mayoría jóvenes estudiantes de la Universidad Veracruzana; aunque también había espectadores de mayor edad, de entre 45 y 70 años, incluyendo algunos académicos de la misma institución.

Desde que entraba a la sala, el espectador podía ver, en lugar del telón, una malla negra, traslúcida, que cubría todo el rectángulo que conforma el frente del escenario. Detrás de 
INVESTIGACIÓNTEATRAL

Revista de artes escénicas y performatividad

Vol. 9, Núm. 13

abril-septiembre 2018
La extinta variedad del mundo

de Alberto Villarreal

Saúl Rivas Meléndez

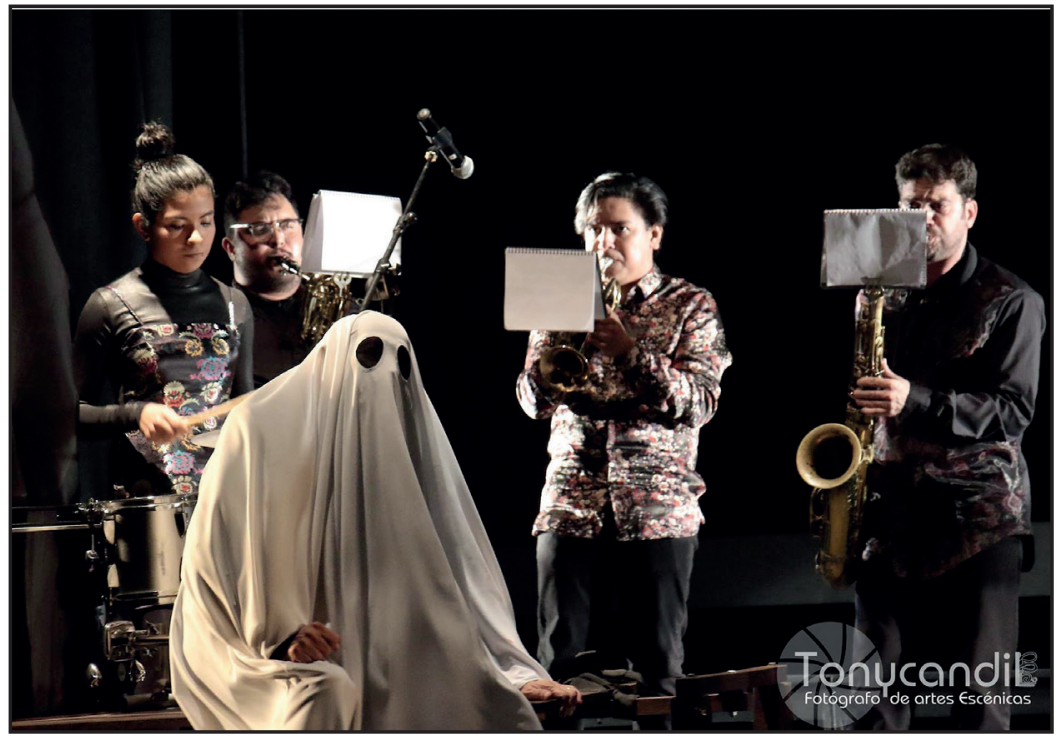

La extinta variedad del mundo, de Alberto Villarreal. Escena con el actor Jorge Castillo y los músicos: Ricardo Uresti (trompeta), Adal Pérez (saxofón barítono), Leandro Luis Rey (saxofón) y Kristina Sánchez (percusiones) Fotografía de Luis Antonio Marín, archivo Candileja, 2017.

ésta se observaba una fila de bancas de color negro, colocadas de frente al público, y dos enormes ventiladores que funcionaban y movían con el aire la quietud de los objetos.

El público poco a poco ocupó sus lugares. No hubo anuncio de primera, ni de segunda, ni de tercera llamada. Fuimos sorprendidos por la aparición de dos actores, Rosalinda Ulloa y Félix Lozano. Sus voces y una campana evocaban la presencia de una vaca, en un ambiente rural. Enseguida, emergieron del fondo a la izquierda, en solemne y cadenciosa procesión, el resto de los actores del elenco: Jorge Castillo, Miriam Cházaro, Juana María Garza, Luisa Garza, Gema Muñoz, Luz María Ordiales y José Palacios, todos vestidos de negro, con la particularidad de que Cházaro y Palacios llevaban máscaras de perros, creando una sensación de extrañeza ante lo diferente. Todos ellos tiraban de un trineo de madera donde viajaba la banda musical, compuesta por cuatro integrantes: Ricardo Uresti (trompeta), Adal Pérez (saxofón barítono), Leandro Luis Rey (saxofón) y Kristina Sánchez (percusiones).

\section{La unificación gestual}

La obra se tejió por medio de símbolos visuales, como trajes masculinos de saco y corbata, o máscaras de perros que portaban algunos actores y que reforzaban la animalidad con la gestualidad corporal; y símbolos auditivos, como los golpes metálicos que acompañaban la acción de disparar una escopeta, o la música que acompañó en todo momento y, que cambiaba, según la escena. Podría decirse que el montaje superó el textocentrismo que critica Hans 
Thies-Lehmann, desechando el montaje convencional de un texto dramático. No obstante, se usaron textos, como uno aparentemente apócrifo que se proyectó sobre el escenario entre una escena y otra, y que describía oscuras formas de venganza con un lenguaje evocador de libros de texto antiguos, lo cual producía un distanciamiento irónico.

La banda de música se quedó en un lugar visible del escenario, era parte palpable del conjunto de elementos que crearon el universo de la obra. Con las notas de sus instrumentos marcaron el tono, a veces fúnebre, a veces festivo, otras veces inquietante o enigmático, de cada escena. Dos parejas se pusieron a bailar, y llamaba la atención que un integrante de cada pareja llevaba puesta una máscara de perro. Mientras bailaban, marcaban el ritmo con un zapateado veracruzano, que auditivamente generó otro código simbólico que contextualizó el montaje en las proximidades culturales de Xalapa.

En una escena siguiente, entró el actor Jorge Castillo quien fue remolcado sobre un diablito. Por su vestimenta, compuesta por un traje sastre de color negro, y por la forma en que éste se relacionaba con los demás personajes de la puesta en escena, el espectador entendió que él era un líder político que se encontraba cerca de la extinción de su vida. El hecho de que él no pudiera valerse por sí mismo remitía a esta interpretación. Efectivamente, unos instantes después de su aparición en escena, este personaje murió.

En la parodia de un ritual funerario fue investido de fantasma. Le colocaron una manta blanca con agujeros en los ojos, el cliché primero fue un símbolo que de tan gastado, repetido y conocido se volvió un lugar común, que como espectadores decodificamos sin esfuerzo y con gracia. Después fue su viuda (la octagenaria y estupenda actriz Luz María Ordiales) quien dictó las normas que ese grupo de personas debían repetir.

Ella se colocó de pie en el centro de la escena, se puso un vaso en la cabeza y se quedó inmóvil durante algunos minutos. Durante este tiempo los demás actores imitaron el gesto de la mujer. Crearon una cadena de movimientos: uno de ellos, José Palacios, se colocó una veladora de vaso de vidrio sobre la cabeza; se hincó ante otra actriz, Juana María Garza, quien la encendió sin tomarla con las manos; él se puso de pie; caminó hacia atrás del escenario; dejó caer la veladora en sus manos y volvió a iniciar la secuencia. Lo mismo realizaron todos y cada uno de los demás actores. La variedad de los seres que habitaban ese universo ficticio había sido aniquilada.

En la escena siguiente, la viuda no se había movido aun del lugar donde se posó. Los demás actores se detuvieron y miraron hacia atrás del escenario. En ese momento, entró lentamente un hombre empujando su carrito de camotes, como si hubiese entrado de la calle. El vendedor de camotes no parecía estar actuando, empujaba su carrito de forma natural, lo que contrastaba con la gestualidad mecánica y repetitiva de los demás intérpretes. Se detuvo en el centro de la escena y accionó el pitido del carrito, que en el contexto mexicano todos asociamos con su oficio. Fue un silbido estruendoso que inundó todo el foro. 
Estábamos frente a una imagen aparentemente inmóvil, pero cinética gracias al viento que acariciaba las telas, el movimiento del humo, y las lenguas de fuego sobre las brasas de carbón del carrito de camotes. El momento duró casi veinte segundos, los cuales en el tiempo de la escena parecieron una eternidad, y me hizo pensar en los paisajes escénicos de Robert Wilson (Lehmann 142). Aquí finalizó el primer acto.

El segundo acto inició con la escena de los partos. Estaban un hombre y otra mujer con máscaras de perro. También estaban varias mujeres vestidas con batas blancas con vientres prominentes. Estos dos elementos sugirieron una situación: el embarazo. Un lugar: un sanatorio. Actuaron de manera simbólica. El cerebro del espectador completaba o construía todo lo demás. Yo, por ejemplo, pensé que el líder político que murió en el acto anterior era un 'cabrón' que le 'tiraba' a lo que se movía.

Enseguida, todas las mujeres dieron a luz, se sacaron de debajo de la bata muñecos, sin la intención de aparentar más de lo que estos objetos eran. Incluso la mujer-perro del acto anterior parió a varios perritos de peluche. Hubo risas por todo el teatro. Entró otra mujer con escopeta en mano y disparó a los recién nacidos; cargó su escopeta vacía y disparó de nuevo. El sonido de la detonación fue simulado golpeando un tambo de metal, sincronizado con la caída al piso de los muñecos. Hasta los perritos de peluche fueron asesinados.

Por si a alguien no le había quedado clara la muerte de los infantes, la escena concluyó con la colocación de cal sobre los muñecos. En este respiro pensé en dos textos: uno el Ubu Rey, de Alfred Jarry. El otro que me llegó a la mente fue El rey se muere, de Ionesco. Ambos tienen por personaje principal al hombre común y ordinario que se vuelve rey idiota y que no es capaz de dirigir con eficacia su pequeño reino. En la obra que estaba viendo el líder muerto era un Ubu o un rey a lo Ionesco.

En la siguiente escena todos los actores que participaban se relacionaban entre sí a partir del uso extraordinario y uniforme de un vaso de vidrio. La realización se basó en un alarde colectivo de equilibrio, de conciencia corporal y conciencia de la relación del actor con el objeto. Las escenas se tejieron a manera de coro. Afirma Sarrazac que en el teatro contemporáneo "el recurso al coro, es a menudo, en una época de desencanto del mundo, la ocasión de una queja fundamental que recuerda la maldición de la desunión, la insalvable separación de los seres." (66) Las actrices ataviadas con vestidos de noche, se sentaron en las bancas una junto a otra. Hombro con hombro, colocaron los vasos de vidrio sobre la cabeza de quien se encontraba a su izquierda; con una ligera inclinación de cabeza dejaron caer el vaso en sus propias manos y volvieron a efectuar la misma cadena de movimientos en un bucle que pareció eterno.

A partir de esta circulación corporal, en apariencia simple, con base en la repetición y en la acción coral, se crearon grandes estructuras visuales, concatenadas por el virtuosismo 
INVESTIGACIÓNTEATRAL

Revista de artes escénicas y performatividad

Vol. 9, Núm. 13

abril-septiembre 2018
La extinta variedad del mundo

de Alberto Villarreal

Saúl Rivas Meléndez

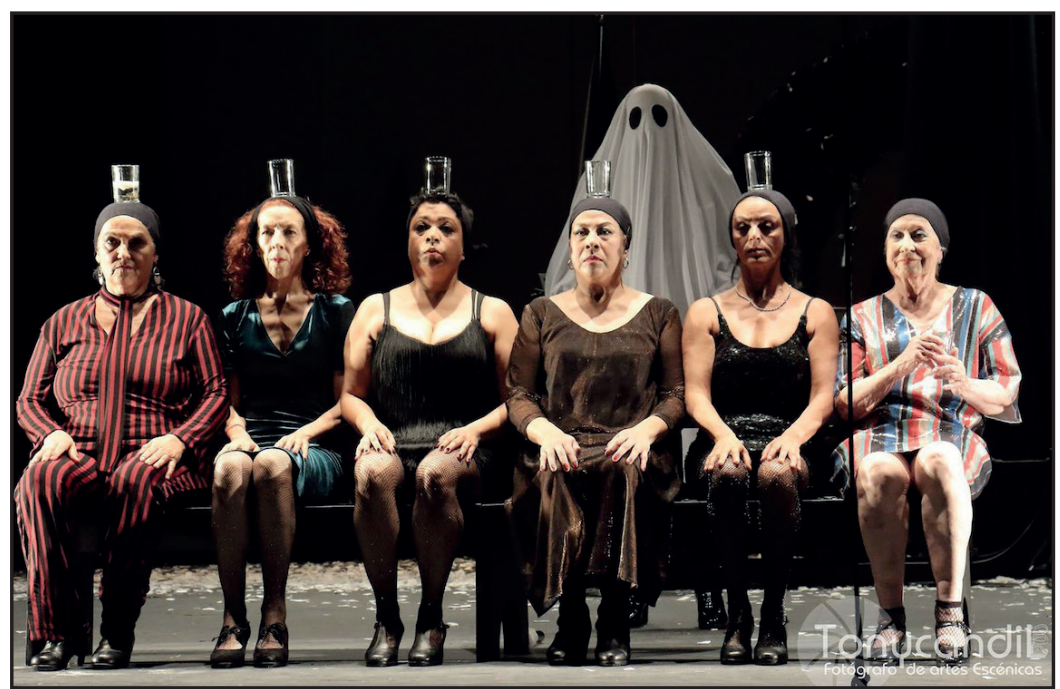

Escena de la obra La extinta variedad del mundo, de Alberto Villarreal. Esena con las actrices Miriam Cházaro, Juana María Garza, Luisa Garza, Gema Muñoz, Luz María Ordiales, y Rosalinda Ulloa, y el actor Jorge Castillo (detrás de ellas). Fotografía de Luis Antonio Marín, archivo Candileja, 2017.

de la precisión que cada uno de los actores adquirió en el trabajo durante los ensayos. Una y otra vez realizaron la secuencia sin equivocaciones. Los actores se encontraban al servicio de un objetivo mayor que los despojó de su individualidad y los homologó en pro de un engranaje perfecto. Si hubiéramos visto a uno solo de ellos ponerse el vaso sobre la cabeza y moverse, el recurso se hubiera agotado pronto, pero el conjunto les dotó de otra fuerza que mientras más se repitió, más impactante y extraordinario se volvió.

A lo largo de los sesenta minutos que duró la obra, los actores se mantuvieron completamente mudos. No es casual que en este montaje se decidió prescindir enteramente de la voz del actor. La voz es una de las características que dotan al ser humano de individualidad. Por lo tanto, su presencia en el mundo enriquece la variedad del mundo. Irónicamente, el director decidió dejarla fuera de esta puesta en escena. En cambio, Alberto Villarreal sacó el mayor provecho de las capacidades corporales de los veteranos actores de la Compañía Teatral de la UV, así como de los recursos técnicos a nivel iluminación, audio y tramoya, sin renunciar a la particular poética escénica que lo caracterizan como director.

\section{Bibliografía}

Alvarado, Ana. Teatro de objetos. Manual dramatúrgico. Buenos Aires: Inteatro, 2015.

Innes, Christopher. El teatro sagrado. El ritual y la vanguardia. México: Fondo de Cultura Económica, 1992.

Lehmann, Hans-Thies. Teatro posdramático. México: Paso de Gato, 2013. 


\section{Ficha técnica de La extinta variedad del mundo}

ORTEUV

Dramaturgia, dirección, iluminación y diseño de espacio: Alberto Villarreal

Asistente de dirección: Yair Gamboa.

Diseño de arte, coreografía y vestuario: Esmirna Barrios.

Escenografía: Iván Cervantes.

Elenco: Jorge Castillo, Miriam Cházaro, Juana María Garza, Luisa Garza, Félix Lozano, Gema Muñoz, Luz María Ordiales, José Palacios y Rosalinda Ulloa.

Diseño sonoro y arreglos musicales: Joaquín López Chas.

Música de: Henry Purcell, Dimitri Shostakovic, Gigi D’Lesio, Beirut, Demian Cerimovic, Leandro Luis Rey, Ricardo Uresti y Joaquín López Chas.

Interpretación e improvisación musical: Ricardo Uresti (trompeta), Adal Pérez (saxofón barítono), Leandro Luis Rey (saxofón), Kristina Sánchez (percusiones) y Yair Gamboa (piano)

Director artístico de la Compañía Titular de Teatro de la Universidad Veracruzana: Luis Mario Moncada. 